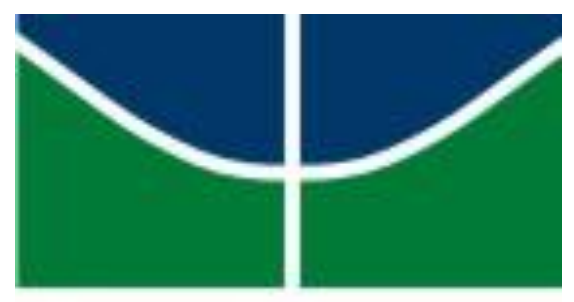

UNIVERSIDADE DE BRASÍLIA (UnB)

FACULDADE DE CIÊNCIA DA INFORMAÇÃO (FCI)

PROGRAMA DE PÓS-GRADUAÇÃO EM CIÊNCIA DA INFORMAÇÃO (PPGCINF)

ANDRÉA CARLA MARQUES DA SILVA

COMPORTAMENTO DE PESQUISA DA INFORMAÇÃO DE USUÁRIOS DE PORTAIS CORPORATIVOS:

Estudo de Caso da Eletrobras Eletronorte

Brasília-DF 


\section{COMPORTAMENTO DE PESQUISA DA INFORMAÇÃO DE USUÁRIOS DE PORTAIS CORPORATIVOS:}

Estudo de Caso da Eletrobras Eletronorte

Dissertação apresentada ao Programa Pósgraduação em Ciência da Informação da Universidade de Brasília como requisito parcial para obtenção do grau de mestre em Ciência da Informação.

Linha de Pesquisa: Comunicação da Informação.

Orientadora: Profa. Dra. Kelley Cristine Gonçalves Dias Gasque.

\section{Brasília-DF}




\section{FOLHA DE APROVAÇÃO}

Título: "Comportamento de Pesquisa da Informação de Usuários de Portais Corporativos"

Autor (a): Andréa Carla Marques da Silva

Área de concentração: Gestão da informaçāo

Linha de pesquisa: Comunicação e Mediação da Informação

Dissertação submetida à Comissão Examinadora designada pelo Colegiado do Programa de Pós-graduação em Ciência da Informação da Faculdade em Ciência da Informação da Universidade de Brasília como requisito parcial para obtenção do título de Mestre em Ciência da Informação.

Dissertação aprovada em: 17 de outubro de 2013.

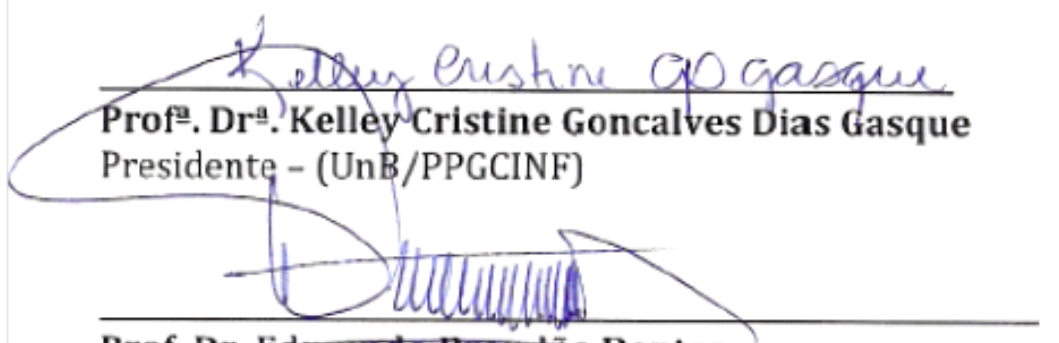

Prof. Dr. Edmundo Brandão Đantas

Membro Externg - (UnB/FAC)

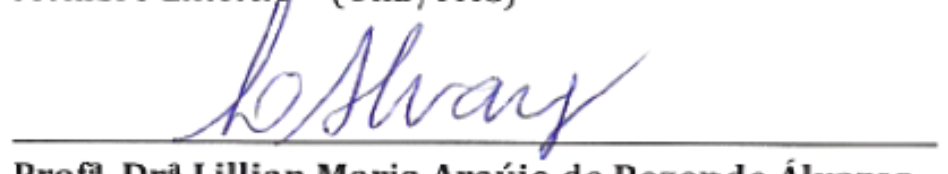

Profe. Drâ.Lillian Maria Araújo de Rezende Álvares

Membro Interno - (UnB/PPGCINF)

Profe. Dria. Sofia Galvão Baptista

Membro Suplente - (UnB/PPGCINF) 


\section{AGRADECIMENTOS}

A Deus, o princípio de tudo e de todos.

A meus protetores espirituais, pela iluminação e motivação em momentos de dúvidas.

A meus pais, pelos incentivos dos passos iniciais - nas letras e na vida.

Aos mestres, pelo esforço empregado no compartilhamento do saber ao longo do caminho.

A meus amigos, pelos momentos de abnegação e incentivo.

A minha filha, Maria Teresa, pelos carinhos e compreensão dos momentos ausentes.

A meu marido, Carlos Eduardo Esch, pelo humor, amor e fé em minha capacidade, além da competência profissional. Você me inspira diariamente.

Ao Hélio Lopez, pelos incentivos na "descoberta do eu" e no enfrentamento dos desafios.

Aos professores do PPGCInf, que contribuíram imensamente com o meu desenvolvimento nessa fase de vida, dentre eles, alguns que fizeram muita diferença: Professores Dr. Murilo Bastos da Cunha, Dra. Sely de Souza Costa, Dra. Suzana Mueller e Dr. André Ancona Lopez. A minha orientadora, Profa. Dra. Kelley Cristine Gasque, que acreditou em mim, mesmo nos momentos em que duvidei de mim mesma.

Aos professores que integraram a banca de avaliação do relatório intermediário de mestrado e a banca examinadora de defesa de dissertação, Profa. Dra. Sofia Galvão Baptista, Profa.Dra. Lillian Maria Araújo de Rezende Alvares e Prof. Dr. Edmundo Brandão Dantas, pela cessão de tempo e de conhecimentos no incremento de meu processo de aprendizagem.

Aos demais profissionais que contribuíram direta e indiretamente com este projeto, os colaboradores da Eletrobras Eletronorte, particularmente o Sr. Francisco Neto, Dra. Eden Brasilia de A. Damasceno, Maja Meira, Hugo Laranjeira, Rosa Maria de Menezes; Maria José Teixeira, e os demais respondentes da pesquisa.

Por último, porém não menos importante, aos funcionários da Faculdade de Ciência da Informação (FCI), especialmente a Jucilene Gomes e Martha Araújo; bem como os da Biblioteca Central dos Estudantes (BCE) da UnB, pela atenção sempre que deles precisei.

A todos, o meu muitíssimo obrigada! 


\section{RESUMO}

Apresenta estudo de caso sobre comportamento de pesquisa da informação dos usuários de portais corporativos, mais especificamente, identifica o perfil dos usuários de portais corporativos e mapeia os padrões de pesquisa da informação para a tomada de decisão, centrando-se especialmente em fatores que estimulam a busca da informação e possíveis obstáculos. Os portais corporativos têm se destacado dentre as organizações competitivas por transcenderem a busca, recuperação e disseminação de informação aos stakeholders, contribuindo com a cultura de interação e compartilhamento de conhecimentos. O estudo realizado no Portal do Conhecimento da Eletrobras Eletronorte utilizou a combinação de métodos quantitativos e qualitativos na análise dos dados coletados para melhor entender a complexidade do fenômeno estudado. O presente estudo toma como referência o modelo de busca e uso da informação de Wilson associado à proposta de Dias, que delimitaram as variáveis utilizadas na pesquisa: acesso, competência e pertinência. Os resultados ratificam a importância do Portal do Conhecimento como fonte de informação qualificada para a tomada de decisão e disseminação do conhecimento organizacional, bem como apresentam o perfil dos usuários composto por profissional experiente, qualificado pelas especializações e vivência na empresa, a maioria do gênero masculino e faixa etária superior a 46 anos. Dentre os fatores que estimulam a busca da informação, destacam-se a centralização do acesso de informações e documentos no portal, com a devida divulgação; além da promoção do compartilhamento de informação entre os públicos-alvo da organização. A falta de letramento informacional e ausência da cultura de compartilhamento de informação entre usuários são aspectos identificados como potenciais obstáculos à pesquisa da informação em portais corporativos.

Palavras-chave: Comportamento de pesquisa da informação. Busca da informação. Tomada de decisão. Portal corporativo. Eletronorte. 


\begin{abstract}
Presents case study of information searching behavior of users of corporate portals, more specifically identifies the profile of corporate portals users and maps search patterns of information for decision making, especially focusing on factors that stimulate the search for information and possible obstacles. Corporate portals have stood out amongst the competitive organizations per transcend the search, retrieval and dissemination of information to stakeholders, contributing to the culture of interaction and sharing of knowledge. The study carried out at the Knowledge Portal Eletrobras Eletronorte utilized the combination of quantitative and qualitative methods in the analysis of data collected to better understand the complexity of studied phenomenon. The present study takes as reference the Wilson's model of information-seeking behaviour related the proposal for Dias, which delimited the variables used in the research: access, competence and pertinence. These results confirm the importance of the Knowledge Portal as a source of quality information for decision making and dissemination of organizational knowledge, as well as present the profile of users composed of experienced professional, qualified by expertise and experience in the company, most males and age range above 46 years. Among the factors which stimulate the search for information, highlights are the centralizing access of information and documents on the portal, with proper disclosure, in addition to promoting the sharing of information between the target groups of the organization. The lack of information literacy and the absence of a culture of sharing information between users are aspects identified as potential barriers to research of the information in enterprise portals.
\end{abstract}

Keywords: Information search behavior. Search of information. Decision making. Corporate portals. Eletronorte. 


\section{LISTA DE FIGURAS}

Figura 1 - O sistema de pesquisas formado pelo "Ciclo da Informação". ............................ 17

Figura 2 - Unidades Regionais Eletrobras Eletronorte................................................. 26

Figura 3 - Contexto analisado pelos gestores da Eletrobras Eletronorte............................. 27

Figura 4 - Sistema de gestão utilizado pelos gestores da Eletrobras Eletronorte. .................. 28

Figura 5 - Sistemas baseados na representação física do conhecimento............................. 31

Figura 6 - Conceitos: dados, informação e conhecimento................................................ 32

Figura 7 - A equação pseudomatemática de Brookes - informação e conhecimento.............. 33

Figura 8 - Processo decisório para a solução de problemas. .............................................. 35

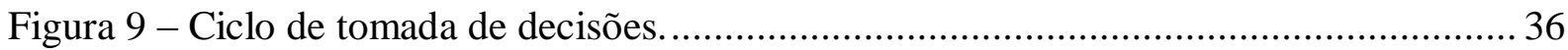

Figura 10 - Uso da informação no ambiente empresarial................................................ 38

Figura 11 - Valor da informação na organização....................................................... 40

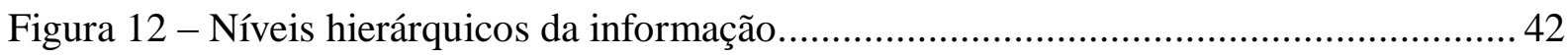

Figura 13 - Subcategorias do comportamento informacional........................................ 49

Figura 14 - Fluxo de informação nas organizações...................................................... 55

Figura 15 - Modelo de comportamento informacional de Wilson..................................... 56

Figura 16 - Modelo revisado de comportamento informacional de Wilson......................... 57

Figura 17 - Processo de tomada de decisão na organização ................................................ 61

Figura 18 - Proposições de valor de um portal corporativo ou intranet ............................... 64

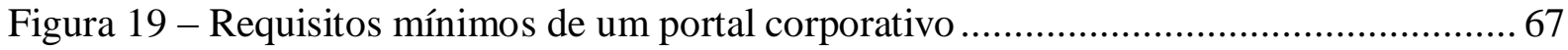

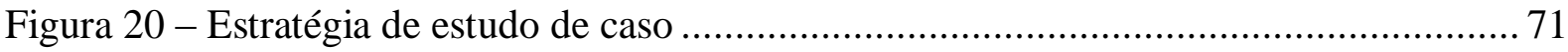

Figura 21 - Destaque ao único filtro do questionário, disponibilizado na parte introdutória. . 81

Figura 22 - Cabeçalho aplicado em cada seção do questionário (identificação) .................. 81

Figura 23 - Reprodução da tela inicial do portal, usada no questionário. ............................ 81 
Figura 24 - Modelo de comportamento de busca da informação....................................... 84

Figura 25 - Modelo de comportamento de pesquisa de informação em portal corporativo.... 87 


\section{LISTA DE QUADROS}

Quadro 1 - Stakeholders da Eletrobras Eletronorte e suas expectativas.

Quadro 2 - Sociedades de Propósito Específico (SPEs), parceiros da empresa.

Quadro 3 - Número de empregados(as) por categoria funcional. 74

Quadro 4 - Composição do corpo funcional. ................................................................. 74

Quadro 5 - Seleção dos instrumentos de coleta de dados de acordo com os objetivos........... 75

Quadro 6 - Finalidades dos instrumentos de coletas de dados utilizados no estudo.............. 76

Quadro 7 - Variáveis do portal do conhecimento analisadas no estudo...............................86

Quadro 8 - Contribuição dos gestores do portal do conhecimento para a pesquisa.............. 111

Quadro 9 - Funcionalidades básicas do portal do conhecimento Eletrobras Eletronorte...... 115

Quadro 10 - Mapeamento de obstáculos e estímulos à pesquisa da informação no ............. 135 


\section{LISTA DE GRÁFICOS}

Gráfico 1 - Respondentes, de acordo com o cargo que ocupam na empresa........................ 90

Gráfico 2 - Proporção dos respondentes em cargo gerencial. ........................................... 91

Gráfico 3 - Classificação dos respondentes quanto ao tempo na Eeltrobras Eletronorte........ 91

Gráfico 4 - Classificação quanto a faixa etária dos respondentes..................................... 92

Gráfico 5 - Classificação dos respondentes quanto ao gênero........................................... 92

Gráfico 6 - Frequência de acesso ao portal do conhecimento Eletrobras Eletronorte. ...........93

Gráfico 7 - Localização das informações qualificadas com facilidade. .............................. 94

Gráfico 8 - Acesso às informações qualificadas com facilidade. .................................... 94

Gráfico 9 - Encontra informações e documentos para uso nas atividades profissionais......... 95

Gráfico 10 - Facilidade de localizar informações para a tomada de decisão........................ 95

Gráfico 11 - Percepção do layout das informações no portal. ............................................ 96

Gráfico 12 - Disponibilidade de recursos no portal que facilitam a pesquisa informação...... 97

Gráfico 13 - Apresentação (compreensível) dos resultados da pesquisa da informação. ....... 97

Gráfico 14 - Promoção do uso e compartilhamento dos conteúdos.................................... 98

Gráfico 15 - Permissão/estímulo à participação dos usuários na produção de novos conteúdos.

Gráfico 16 - Oferta de meios para facilitar a coleta de ideias, informações e sugestões entre os usuários.

Gráfico 17 - Divulgação das novas aquisições/novo conteúdo disponibilizado.

Gráfico 18 - Conhecimento de técnicas que facilitam a pesquisa da informação. 101

Gráfico 19 - Utilização de técnicas que facilitam a pesquisa da informação. 101

Gráfico 20 - Interesse em conhecer técnicas e ferramentas de auxílio em pesquisa de informação

Gráfico 21 - Pesquisa sobre ações/decisões já tomadas (passado). 104

Gráfico 22 - Pesquisa para complementar ação/decisão atual (presente). 104 
Gráfico 23 - Pesquisa para dar suporte a ação/decisão a ser tomada (futuro). 105

Gráfico 24 - Pesquisa sobre conteúdo técnico.

Gráfico 25 - Pesquisa para atualizar-se sobre produtos e serviços da Eletrobras Eletronorte.

Gráfico 26 - Pesquisa para atualizar-se sobre o mercado/área de negócios. 106

Gráfico 27 - Pesquisa para atualizar-se sobre informações políticas. 107

Gráfico 28 - Pesquisa para localizar novos talentos e/ou novas parcerias. 107 


\section{LISTA DE TABELAS}

Tabela 1 - Classificação dos respondentes de acordo com nível de escolaridade. 90

Tabela 2 - Classificação de acordo com as dificuldades para pesquisar informações. 96

Tabela 3 - Conhecimento de técnicas de pesquisa de informação 102

Tabela 4 - Interesse no aprendizado de técnicas de pesquisa de informação. 103

Tabela 5 - Sugestões/críticas dos respondentes. 108 


\section{LISTA DE ABREVIATURAS}

ALFIN

ApO

ARIST

BNDES

Eletrobras

Eletronorte

ERIC

GAE

GESEC

IBGE

IBICT

IIP

LISA

NTICs

P\&D

P\&D+I

PND

PPGCInf

SOFTEX

TECSOFT

TICs

UCEL

$\mathrm{UnB}$
Alfabetização Informacional

Aprendizagem Organizacional

Annual Review of Information Science and Technology

Banco Nacional de Desenvolvimento Econômico e Social

Centrais Elétricas Brasileiras S.A.

Centrais Elétricas do Norte do Brasil

Education Resources Information Center

Assessoria de Educação e Conhecimento

Gerência de Gestão do Conhecimento

Instituto Brasileiro de Geografia e Estatística

Instituto Brasileiro de Informação em Ciência e Tecnologia

Instituto Intranet Portals

Library and Information Science Abstracts

Novas Tecnologias da Informação e Comunicação

Pesquisa e desenvolvimento

Pesquisa, Desenvolvimento e Inovação

Programa Nacional de Desestatização

Programa de Pós-graduação em Ciência da Informação (UnB)

Sociedade Brasileira para Promoção da Exportação de Software

Centro de Tecnologia de Software de Brasília

Tecnologias da Informação e Comunicação

Universidade Corporativa Eletronorte

Universidade de Brasília 
SUMÁRIO

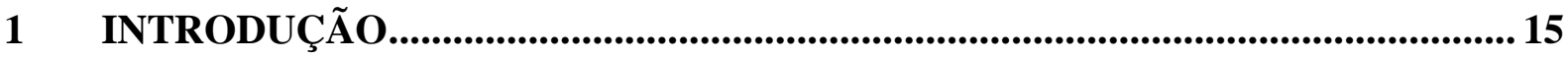

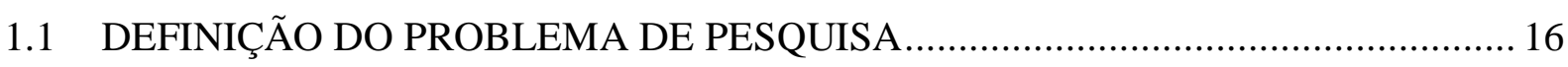

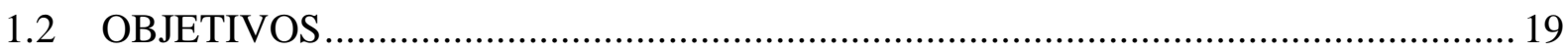

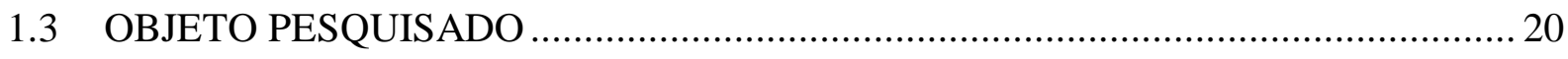

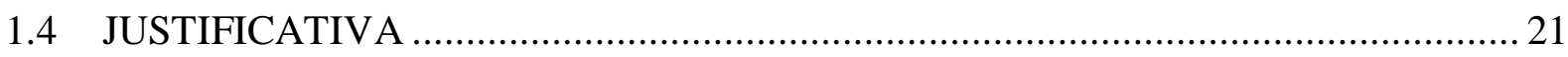

1.5 O CONTEXTO

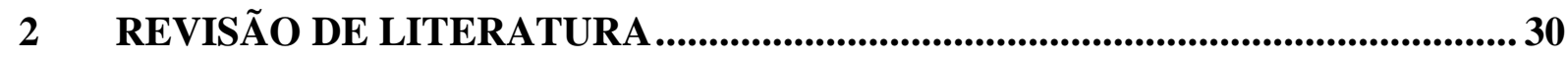

2.1 A INFORMAÇÃO PARA A TOMADA DE DECISÃO …………………………....... 30

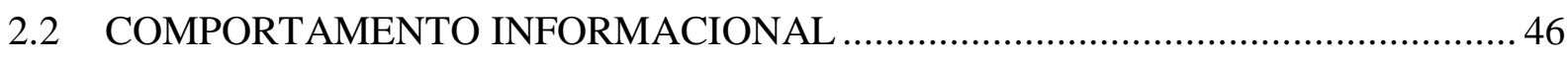

2.3 EMERGÊNCIA DO LETRAMENTO INFORMACIONAL ……...................................58

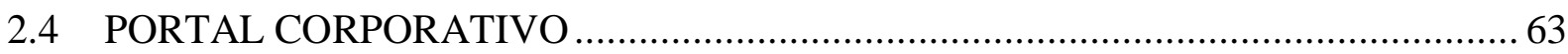

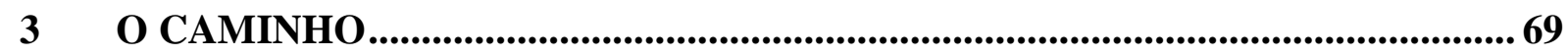

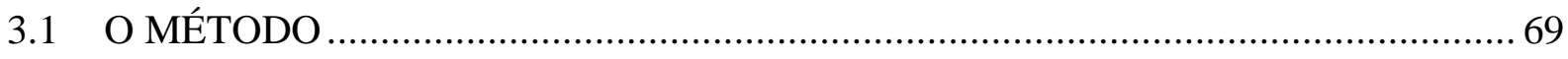

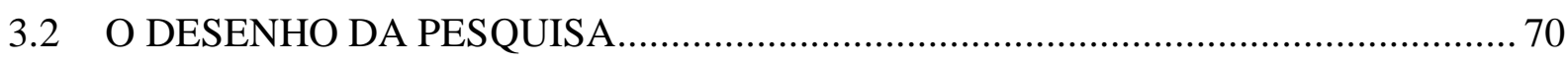

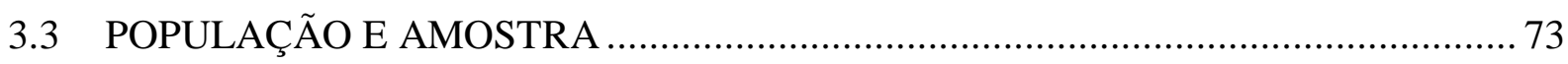

3.4 INSTRUMENTOS DE COLETA DE DADOS …………………………............ 75

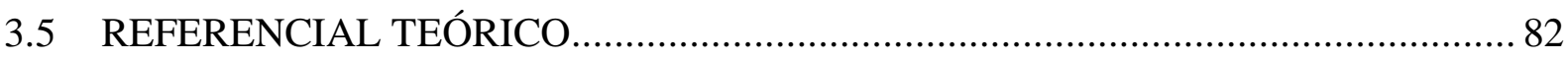

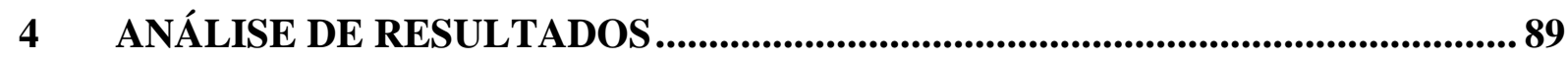

4.1 DADOS COLETADOS POR MEIO DO QUESTIONÁRIO …………………….......... 89

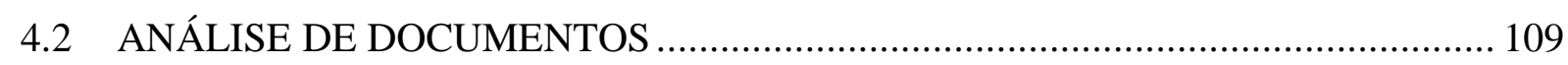

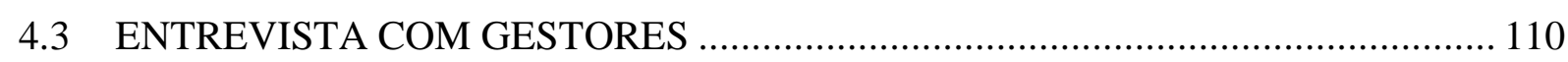

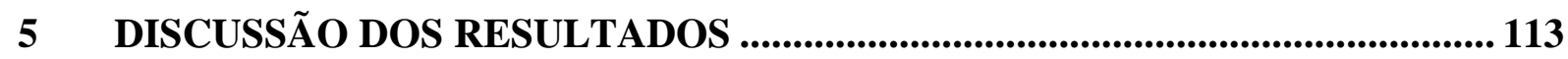

5.1 LEVANTAR DADOS GERAIS SOBRE A EMPRESA E O OBJETO DE PESQUISA

5.2 IDENTIFICAR OS SERVIÇOS DISPONIBILIZADOS E OS RECURSOS INFORMACIONAIS DO PORTAL DO CONHECIMENTO DA ELETROBRAS ELETRONORTE 
5.3 IDENTIFICAR O PERFIL DOS USUÁRIOS DO PORTAL DO CONHECIMENTO ELETROBRAS ELETRONORTE

5.4 MAPEAR OS PADRÕES DE COMPORTAMENTO DE PESQUISA DA INFORMAÇÃO DOS USUÁRIOS DO PORTAL DO CONHECIMENTO DA ELETROBRAS ELETRONORTE.

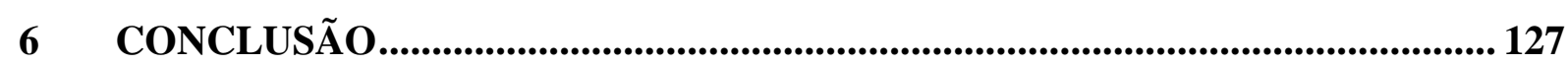

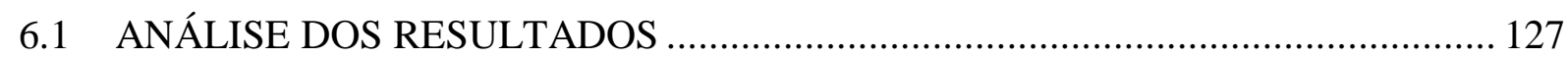

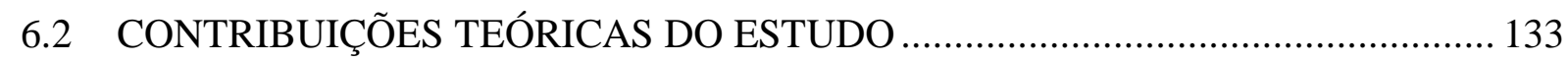

6.3 CONTRIBUIÇÕES PRÁTICAS DO ESTUDO ……………………………........ 134

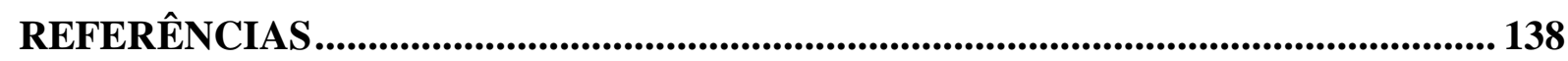

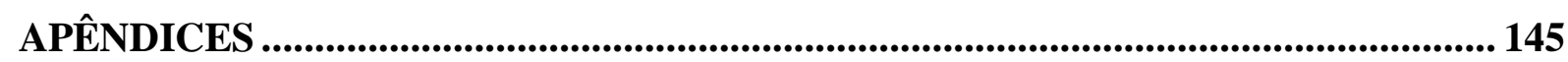

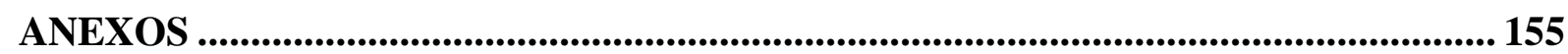




\section{INTRODUÇÃO}

O que diferencia nossa época das anteriores não é só a quantidade, a diversidade e a complexidade dos conhecimento acumulados, mas a forma deliberada e sistemática como eles vêm sendo produzidos e organizados e, mais ainda a intenção contida nesta produção. [...] nunca a busca de novos conhecimentos esteve tão comprometida com a obtenção de lucros ou outras formas de dividendos quanto está a ciência de hoje, vinculada às diferentes formas capitalistas de atuação sobre a realidade. (TOMANIK, 2004. p. 23).

A pesquisa apresenta estudo de caso sobre o comportamento de pesquisa dos usuários de Portais Corporativos, com objetivo de identificar o perfil dos usuários dos portais e mapear os padrões de comportamento de pesquisa da informação, bem como caracterizar aspectos que influenciam a busca da informação e possíveis obstáculos.

$\mathrm{Na}$ Ciência da Informação, comportamento de pesquisa da informação é o termo empregado para caracterizar o nível micro do comportamento informacional, ou seja, aquele em que o indivíduo interage com diversos tipos de sistemas de informação (GASQUE, 2008a). O tópico é tratado de forma mais aprofundada na revisão de literatura. Wilson (2000) define comportamento informacional como a totalidade do comportamento humano em relação ao uso de fontes e canais de informação, incluindo a busca da informação passiva ou ativa.

Inicialmente, registram-se os objetivos que motivaram a realização do trabalho e a justificativa. O estudo de caso é realizado no Portal do Conhecimento da Eletrobras Eletronorte por apresentar constante demanda de informações qualificadas no processo de gestão, devido à intensiva busca de competitividade no setor. Trata-se de um portal corporativo com potencial de tornar-se a principal fonte de busca de informações na organização. Em seguida, descreve-se a metodologia e os instrumentos utilizados documentos da empresa, questionário autoadministrado e entrevista semiestruturada, bem como apresenta-se o referencial teórico que fundamenta a pesquisa: o modelo de busca da informação de Wilson (1981), com enfoque nas necessidades cognitivas de usuários de fontes de informação agregado à proposta de Dias (2001b) para caracterização do portal.

Após a metodologia, apresentam-se os resultados e as análises dos principais aspectos abordados. A pesquisa mostra a contribuição dos portais no processo de tomada de decisão em ambiente corporativo. 


\subsection{DEFINIÇÃO DO PROBLEMA DE PESQUISA}

[...] Empresas bem administradas organizam seus recursos de informação de maneira a permitir rapidez tanto na localização quanto no uso. Quando os gerentes têm consciência da informação e da inteligência que já está entre os muros de uma organização e no cérebro dos funcionários, todos eles respondem com mais eficiência às mudanças de mercado. (MILLER, 2002, apud AMARAL, 2007, p.25)

Em uma economia globalizada, as organizações competitivas consideram a informação como algo que transcende o bem econômico e passa a ser percebida como fator essencial na corrida pela conquista e, principalmente, manutenção de mercados, formados por consumidores cada vez mais exigentes. Além disso, a crescente utilização das Tecnologias da Informação e Comunicação (TICs) é uma das características marcantes das sociedades consideradas mais desenvolvidas, uma vez que estão em um ambiente de incertezas e desafios constantes impostos pelo mercado altamente competitivo: concorrência acirrada e consumidores bem informados, ávidos por mudanças. A informação e o conhecimento desempenham papel central nas sociedades, desde muito tempo, como apontam Briggs e Burke (2006, p. 31) em referência à época dos descobrimentos: "Sem dúvida constitui uma tradição o fluxo de informações seguir o fluxo do comércio, pois os mercadores operando por mar ou terras traziam novidades juntamente com a mercadoria”.

Le Coadic (2004) destaca a importância da informação ao considerar que sem informação não haveria pesquisa e produção de conhecimento. A importância da informação está justamente na necessidade da renovação constante e na livre circulação de conhecimento. $\mathrm{Na}$ sociedade da informação ${ }^{1}$, é possível identificar a estreita relação entre o sistema de produção e a ciência. Constata-se o importante papel da comunicação da informação, que assegura a troca de informações sobre as demandas e os produtos em desenvolvimento, promovendo a interação entre cientistas - sejam eles da universidade ou da indústria - e consumidores, de uma forma cíclica, no qual os três processos de produção da informação construção, comunicação e uso - sucedem-se e alimentam-se reciprocamente, semelhante ao sistema econômico que envolve produção, distribuição e consumo.

1 O termo "sociedade da informação" passou a ser empregado no final do século XX em substituição ao conceito de "sociedade pós-industrial" e apresenta o novo paradigma técnico-econômico, em referência às transformações técnicas, organizacionais e administrativas, centradas nos insumos da informação proporcionados pelos avanços tecnológicos na microeletrônica e telecomunicações (WERTHEIN, 2000). 
Figura 1 - O sistema de pesquisas formado pelo "Ciclo da Informação".

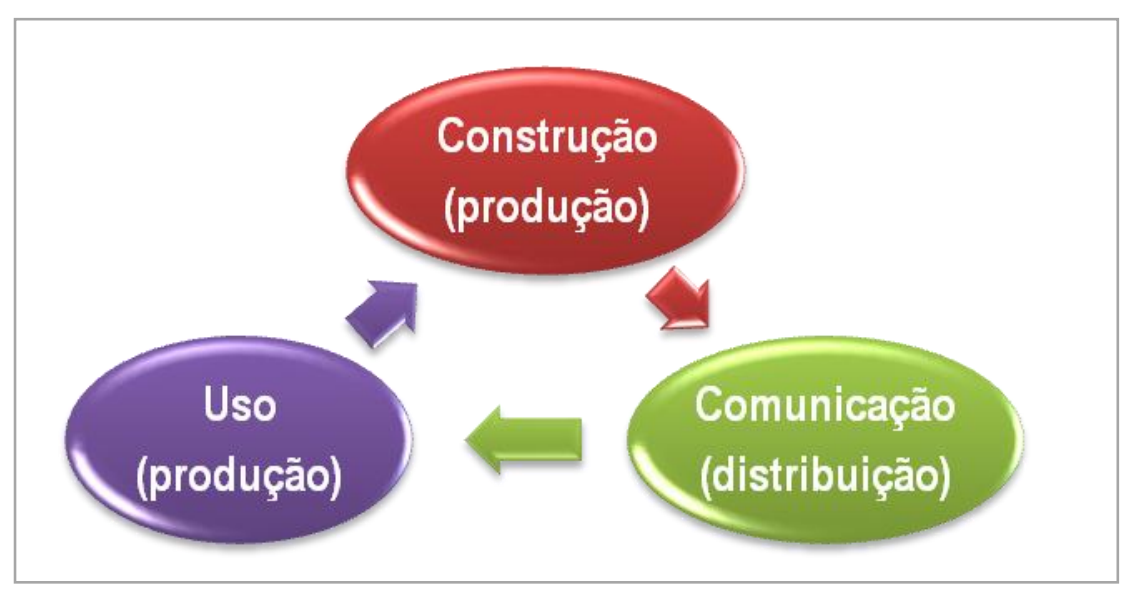

Fonte: adaptado de Le Coadic (2004, p. 10).

Nesse sentido, Choo (2006, p. 53) comenta que "[...] da construção do conhecimento resultam novos conhecimentos que levam a inovações, novos produtos e novas capacidades organizacionais". Atualmente, a valorização do conhecimento supera o capital ou mesmo o trabalho para tornar-se recurso essencial na sociedade pós-capitalista ou sociedade do conhecimento (DRUCKER, 1992). Esse contexto, bastante dinâmico, demanda mudanças e reflexões contínuas por parte dos protagonistas, o que leva as organizações a buscarem, repetidamente, meios de compensar as perdas e tentar acompanhar a velocidade das transformações, procurando alterar também a forma de produzir, registrar, representar e difundir o conhecimento, na tentativa de tornar eficaz o processo de Aprendizagem Organizacional (ApO - a troca de conhecimento do conjunto dos indivíduos que representam a organização, mesmo que cada pessoa, individualmente, não reflita a capacidade de aprendizagem de uma instituição (FERNANDES, 1999). A abordagem utilizada para o trabalho evidencia a relação com os processos e resultados dentro das organizações, como estas organizam e gerenciam o conhecimento, modificando o ambiente e a cultura organizacional.

Esta (re)evolução proveniente das novas formas de aprendizagem sugere a emergência de um modelo de sociedade, baseada em meios mais eficazes de acesso ao conhecimento, em que predominam ferramentas para disseminar novas formas de gestão do conhecimento e, por isso, tem sido chamada de "sociedade da aprendizagem" (GASQUE; TESCAROLO, 2004). No atual cenário, em que se identifica grandes quantidades de informação, percebe-se que não basta torná-la disponível, mas torna-se essencial garantir o desencadeamento do processo de aprendizagem, de forma contínua e em estágios progressivos, partindo do dado para a 
informação, e em seguida, para o conhecimento e, por fim, evoluindo até atingir a inteligência.

\begin{abstract}
O conhecimento, mesmo reconhecido como experiência subjetiva, pessoal e intransferível, pode ser exteriorizado como informação para outro ser humano mediante discurso, utilizando símbolos, indícios, sinais, imagens, fala ou escrita. [...] Esse conhecimento relacional, advindo da interação sujeito-mundo, depende da história prévia de quem aprende, envolvendo suas experiências, vivências e memórias e, portanto, o significado pessoal e emocional. [...] Esse conhecimento busca dar algumas respostas às indagações humanas, tornando-se condição necessária para o bem-estar, desenvolvimento e progresso da humanidade. (GASQUE, 2004, pp.36, 37).
\end{abstract}

Coadjuvantes no processo de aprendizagem, as TICs viabilizam a disseminação social do conhecimento de maneira descentralizada e rápida. "É imperativa a existência de diferentes tipos de suportes e canais de comunicação para a coletivização do conhecimento", defende Miranda (2003, p. 163), pois de outra forma ficaria bem mais difícil atingir metas em uma organização - sistema composto por pessoas com histórias, valores e culturas diferentes, envoltos por um ambiente formal, que precisa se comunicar e se relacionar de forma endógena e exógena com stakeholders ${ }^{2}$ (NASSAR, 2008).

Gestores têm avaliado a institucionalização da aprendizagem como meio para a evolução da pesquisa e desenvolvimento (P\&D). Isso porque as rápidas mudanças tecnológicas influenciam diretamente as organizações, causando turbulências nos processos produtivos e produtos, que ampliam as complexidades e incertezas sobre os ambientes de negócios (FERNANDES, 1999). Como atores do cenário, os profissionais da nova economia precisam de qualificação diferenciada, que os tornem capazes de desempenhar novos papéis, os quais exigem conhecimentos multidisciplinares para lidar com a realidade social e mercadológica. "O fato de a informação ter um valor competitivo vem exigindo uma formação múltipla para uma atuação também múltipla" (BAPTISTA, 2007, p. 82). Antes restrito à alta administração, o processo decisório demanda que a informação estratégica ${ }^{3}$ chegue também aos escalões mais baixos para auxiliar na tomada de decisão, de forma a contribuir na obtenção de soluções eficazes. Na visão de Choo (2006, p. 54), "O objetivo da tomada de decisões é, portanto, a seleção de um curso-padrão de ação que aproxime a

\footnotetext{
2 Stakeholders é a denominação destinada aos grupos de interesses das organizações, afetados direta ou indiretamente pelas atividades que exercem na comunidade/sociedade. (LUPETTI , 2007).

3 Informação estratégica é aquela que contém elementos passíveis de contribuir com a estratégia da empresa, seja para definição, eventuais correções de rumo ou até para reformulação completa. (SANTOS, 2001).
} 
organização de seus objetivos, mas que também a ajude a se adaptar ao ambiente mutável registrado na atividade de criação de significado".

Para tanto, as organizações reinventam-se e transformam-se para gerar aprendizado constante em diversas áreas, constituindo-se em Organizações de Aprendizagem, as Learning Organization (SENGE, 1990). Tal conceito envolve a ApO orientada para a formação de competências que promovam o encontro entre conhecimento e estratégia (BEMFICA; BORGES, 1999), componentes essenciais para a tomada de decisão no ambiente organizacional, contexto desta pesquisa. Na atual situação da economia, vale salientar que não basta estar em sintonia com o mercado, é necessário que os administradores tenham competência para lidar com a informação e transformá-la em conhecimento útil à organização (AMARAL, 2007).

De acordo com Davenport (2003), pode-se incorporar o conhecimento em máquinas, mas aquele que está em nossa mente, chamado de conhecimento tácito (NONAKA; TAKEUCHI, 1997) é bastante difícil de categorizar, localizar ou mesmo gerenciar. Por isso, as organizações modernas criam sistemas e incentivam lideranças e liderados ao desenvolvimento, armazenamento e transferência de conhecimentos entre si e o mercado, de forma contínua, proporcionando a geração de conhecimento organizacional (SGUARIO; TOMAÉL, 2011), cujo emprego eficaz pode gerar valor agregado aos produtos e serviços da empresa, proporcionando vantagem competitiva.

Um recurso crucial para ampliar significativamente a acessibilidade, disponibilidade e uso da informação ao público-alvo é o portal corporativo, um tipo de plataforma digital que, aliada às técnicas motivacionais e processos de ApO, mostram-se eficazes na transformação da aprendizagem individual em aprendizagem coletiva. Isso por incorporar o conhecimento de cada membro da organização participante às práticas organizacionais atuais e tornarem-se colaboradores das práticas futuras (MORESI; MENDES, 2010).

Diante do contexto no qual profissionais de diversas áreas do conhecimento têm constante necessidade de informação qualificada e, ao mesmo tempo, demandam o emprego eficaz da informação, julga-se adequado investigar: qual é o comportamento de pesquisa da informação dos usuários de uma plataforma digital, como um portal corporativo?

\subsection{OBJETIVOS}

Considerando a relevância da informação como meio da organização obter vantagem competitiva em uma economia globalizada, define-se como objeto de pesquisa o 
comportamento de pesquisa da informação de usuários de portal corporativo. As análises foram realizadas particularmente no Portal do Conhecimento da Eletrobras Eletronorte, em consonância com os objetivos geral e específicos.

A seguir, o detalhamento dos objetivos alcançados no trabalho.

\subsubsection{Objetivo geral}

Analisar o comportamento de pesquisa informacional dos usuários do portal corporativo da Eletrobras Eletronorte.

\subsubsection{Objetivos específicos:}

a) Levantar dados gerais sobre a empresa e o objeto de pesquisa;

b) Descrever os recursos informacionais do portal do conhecimento Eletrobras Eletronorte;

c) Identificar o perfil (dados demográficos) dos usuários do Portal do Conhecimento Eletrobras Eletronorte;

d) Mapear os padrões de comportamento de pesquisa da informação dos usuários do Portal do Conhecimento Eletrobras Eletronorte.

\subsection{OBJETO PESQUISADO}

A presente pesquisa analisa o comportamento de pesquisa informacional de usuários de portais corporativos do conhecimento, mediante estudo de caso ocorrido na Eletrobras Eletronorte. Trata-se de uma empresa brasileira do setor elétrico, que desenvolveu um portal de corporativo com objetivo de promover a criação, disseminação e compartilhamento de conhecimentos entre suas diversas unidades.

O Portal do Conhecimento da Eletrobras Eletronorte está vinculado à Assessoria de Educação e Conhecimento (GAE), subordinada à Superintendência de Desenvolvimento e Educação. É um produto destinado, basicamente, à pesquisa da informação técnica, uma vez que as grandes obras de engenharia são o negócio da organização. A ferramenta apresenta diversas informações, processos, projetos, atividades, ações, serviços e outros recursos que a empresa necessita para desempenhar suas atividades rotineiras e até estratégicas, que apoiam a tomada de decisão. Sob este aspecto, tem a função de viabilizar o acesso a informações armazenadas (interna ou externamente) na organização com a finalidade de produzir um bem ou um serviço (DIAS, 2001b). 


\subsection{JUSTIFICATIVA}

O sucesso ou fracasso de uma organização, em muitos casos, dependerá exclusivamente da eficácia do gerenciamento da informação, como um modo de antecipar-se e reagir às ações dos concorrentes mais importantes. [...] A chave para o monitoramento do ambiente e para a tomada de decisões estratégicas acertadas depende da disponibilidade de informação relevante, no momento certo, e com dosagem e grau de detalhamento suficientes para que seja efetivamente útil. (YANAZE, 2006, p. 213)

A pesquisa teve origem em uma questão prática: a literatura existente nas Ciências da Informação e da Computação e na Administração aborda as dificuldades de pesquisa da informação qualificada no apoio ao processo de tomada de decisão apesar da (e devido à) imensa diversidade e quantidade de informação disponível. Amaral (2007) compreende a importância da gestão da informação como meio de organizar a imensurável quantidade de informação que circula atualmente na sociedade da informação para agregar-lhe valor, e transformá-la em insumo essencial para a tomada de decisão e obtenção de resultados eficazes. Isso por sua vez, pode ampliar a vantagem sobre a concorrência.

Esse contexto demanda mudanças e reflexões contínuas por parte dos atores, o que leva as organizações a buscarem meios de compensar as perdas e acompanhar a velocidade das transformações. Amaral (2007) sugere que as mudanças ultrapassam a área econômica e atinjam também as áreas social, política e cultural. Isso nos leva à condição de que enormes quantidades de informação fomentam a redundância (SANTOS; BERAQUET, 2001). Tal fato leva algumas instituições a trabalharem em prol da redução da sobrecarga de informações sobre seus gestores, pois sabem que mesmo àquelas advindas dos sistemas utilizados na empresa não garantem o emprego eficaz.

No referido contexto, o processo de recuperação e o emprego eficaz de informações úteis $^{4}$ em organizações demandam contínua melhoria de procedimentos, metodologias e ferramentas, inclusive o conhecimento de fontes apropriadas ao universo da busca e uso da informação (SANTOS; BERAQUET, 2001). Logo, a existência de um sistema que permita disseminar e compartilhar as informações corporativas de forma mais ágil e eficaz torna-se essencial para integrar ações e promover a geração de ideias.

\footnotetext{
${ }^{4}$ Informações úteis são aquelas que contribuem para a realização dos objetivos da empresa, formulação de estratégias e táticas (SANTOS; BERAQUET, 2001).
} 
Surgem então os Portais Corporativos transcendendo a função de meros canais de comunicação e assumem o patamar de centro de informações qualificadas. Outra característica importante dos portais corporativos - e o que levou à geração de seu nome consiste na capacidade de integração de sistemas heterogêneos em uma única aplicação, a qual é considerada como "porta de entrada" para os sistemas de informação (DIAS, 2001b). Ainda, associam diversas funções tais como gestão de documentos, inteligência empresarial, intranet, dentre outras, o que favorece a disseminação de informação no contexto organizacional.

Apesar do aparato proporcionado pelas TICs, Santos e Beraquet (2001) afirmam que as empresas em geral não dispõem de habilidades para organizar e capitalizar informações. Tal situação é corroborada por Davenport (2003), que sinaliza sobre os ambientes informacionais internos das organizações, ainda empobrecidos apesar de volumosos investimentos. O autor alerta também sobre o custo das decisões baseadas em dados inúteis, informação errada ou simplesmente não utilização da informação correta para a tomada de decisão, que podem gerar produtos ou serviços que não atendem ao consumidor e resultam, por sua vez, em encalhe do estoque, mal funcionamento, instalações precárias ou máquinas improdutivas. Relevante destacar que a tomada de decisão, em geral, integra o cotidiano de gestores, dirigentes e demais colaboradores dos diversos níveis de organizações integrantes da economia atual.

Bitencourt (2001) apresenta uma solução utilizada por organizações competitivas na tentativa de minimizar ou erradicar estes problemas - o emprego da ApO como meio de desenvolver estratégias e procedimentos para contornar a incompetência informacional e, com isso, atingir melhores resultados empresariais resultantes da participação efetiva de colaboradores no processo de aquisição e disseminação de conhecimento, de forma contínua. Outro ponto importante, no que concerne à contribuição da $\mathrm{ApO}$, centra-se no processo de desenvolvimento de competências gerenciais, essenciais para desenvolver ambiente favorável à gestão do conhecimento tácito e à inovação.

$\mathrm{O}$ processo de aprendizagem consolida-se à medida que os principais gestores "aprendem juntos" - que compartilham crenças e metas e providenciam os recursos necessárias para implantarem o processo de aprendizado. O maior desafio é identificar novas ferramentas e métodos de gestão que contribuam com o aprendizado organizacional de forma rápida e eficaz e possibilitem o consenso sobre o processo de mudança. A expectativa é que a aprendizagem individual seja transformada em coletiva e o conhecimento individual seja incorporado às práticas organizacionais (BITENCOURT, 2001). 
Para pesquisar as condições que contribuem para o processo de pesquisa da informação na tomada de decisão selecionou-se uma organização de reconhecida competência tecnológica - a Eletronorte, que integrou o ranking das empresas mais inovadoras do Brasil em 2010 e $2011^{5}$, ocupando o $17^{\circ}$ e $19^{\circ}$ lugar. A avaliação foi realizada da Revista Época Negócios em parceria com consultoria A. T. Kearney (out/2011). Não obstante, a empresa figurou também na lista de finalistas IT Leaders $2010^{6}$ - categoria Governo - oferecido pela Revista Computerworld. Além destes, ficou com a $11^{\mathrm{a}}$ posição no ranking geral pela Revista Information $\mathrm{Week}^{7}$, que elegeu as "100+ inovadoras" do país e, segundo os editores, por pouco não figurou dentre as “Top 10” (PAVONI, 2010, p. 98).

Para viabilização do estudo, foi feito um recorte dentre as inúmeras mídias e fontes de informação disponibilizadas pela empresa. Optou-se pelo Portal do Conhecimento da Eletrobras Eletronorte por ser um canal utilizado para transmitir informações estratégicas aos usuários - colaboradores e demais stakeholders - os quais assumem ora o papel de receptores, ora de emissores da informação. A proposta da pesquisa é contribuir com o constructo no campo da Ciência da Informação, particularmente no que tange ao comportamento de pesquisa da informação e à disseminação do conhecimento via portais corporativos, área em franco desenvolvimento nos campos acadêmicos e empresarial. Da mesma forma, pretende-se fomentar este desenvolvimento, pela inclusão de reflexões e experimentos que possam colaborar com o debate sobre o comportamento de pesquisa da informação de usuários de portais corporativos.

\subsection{O CONTEXTO}

\subsubsection{Evolução do setor elétrico brasileiro}

O tópico aborda breve explanação sobre a evolução do setor elétrico no Brasil, desde o início, na época do império, até a atualidade. A proposta é contextualizar o ambiente de atuação da Eletrobras Eletronorte: o caráter estratégico do setor para o país, a submissão à regulação e às questões ambientais e sociais, dentre outros fatores que compõem o ambiente de alta competitividade para a empresa.

\footnotetext{
5 Ranking do prêmio 2010 e 2011 disponível em:

<http://epocanegocios.globo.com/Revista/Common/0,EMI271272- 16364,00-

AS+EMPRESAS+MAIS+INOVADORAS+DO+BRASIL.html>

${ }^{6}$ Ranking disponível em: <http://computerworld.uol.com.br/finalistas-it-leaders-2010>.

${ }^{7}$ Revista Information Week Brasil, 28 set. 2010.
} 
De acordo com Gomes (2002), a primeira iluminação elétrica inaugurada no país foi na Estação Central da Ferrovia Dom Pedro II, também conhecida como Central do Brasil, em 1879, na cidade do Rio de Janeiro. Apesar de ser considerada um marco inicial do setor elétrico, a fonte de energia foi um dínamo, que também alimentou a primeira iluminação pública, três anos depois, no trecho onde existe hoje a Praça da República. Em 1883, surgiu a unidade geradora que inaugurou a prestação do serviço público de iluminação na América do Sul. Tratava-se de termelétrica com $52 \mathrm{KW}$ de capacidade, que alimentava apenas 39 lâmpadas, instalada em Campos, estado do Rio de Janeiro. No mesmo ano, inaugurou-se a primogênita das usinas hidrelétricas do país em Diamantina, Minas Gerais. No período entre 1890 e 1900, foram instaladas várias pequenas usinas, termelétricas principalmente, como meio de atender à demanda por iluminação pública, e servir ao propósito das áreas de mineração, beneficiamento de produtos agrícolas e suprimento das indústrias têxteis.

Conforme Gomes (2002), no final do século XIX e início do século XX ocorre a expansão urbana das cidades do Rio de Janeiro e São Paulo, atrativo para o capital estrangeiro investir em instalação de companhias destinadas a explorar diversos serviços urbanos - que incluíam transportes, distribuição de gás e telefonia, além da iluminação pública - na então Capital da República. Tais companhias sofreram as tentativas iniciais de regulação, somente concretizadas nos anos 30, com a intervenção do Governo Federal na gestão do setor de águas e energia elétrica, devidamente formalizado pelo Código de Águas (Decreto 24.643, de 10 de julho de 1934), o qual garante à União criar leis e outorgas de concessões de serviços públicos. Na década seguinte, o Estado assume o papel na produção do setor com a criação da Companhia Hidro Elétrica do São Francisco - CHESF. Algumas décadas depois ocorreram importantes mudanças na legislação tarifária do país, inclusive legislação própria para garantir de $10 \%$ a $12 \%$ de retorno sobre o capital investido com intuito de dar suporte financeiro e financiar a expansão do setor com capital da iniciativa privada (nacional e estrangeiro), além de recursos junto à própria Eletrobras.

Nos anos 90 sucederam grandes mudanças, dentre elas a chegada do Programa Nacional de Desestatização e, em 1996, o Projeto de Reestruturação do Setor Elétrico Brasileiro implantado pelo Ministério das Minas e Energia, que proporcionou consequências importantes para o setor como alteração da cadeia produtiva. Os processos de geração, transmissão, distribuição e comercialização de energia elétrica transformaram-se em áreas de negócio independentes, e progressivamente, a geração e a comercialização foram desreguladas com objetivo de incentivar a competição. A transmissão e distribuição 
continuaram como serviços públicos. Outra mudança foi a criação da agência reguladora do setor, a Agência Nacional de Energia Elétrica - ANEEL, ainda em 1996. (GOMES, 2002).

Na virada do século, com o modelo de geração baseado em usinas hidrelétricas, o país passa por um período de racionamento devido ao baixo nível dos reservatórios por conta da ausência de chuvas. $\mathrm{O}$ fato comprometeu o desenvolvimento do setor, porém incentivou a busca por inovações como as termelétricas operadas por bagaço de cana ou gás natural - um grande apoio na questão da sustentabilidade ambiental. Emergem projetos como pequenas centrais hidrelétricas, fontes não convencionais e programas de conservação de energia. Gomes (2002, p. 16), descreve o cenário econômico do setor em dezembro de 2002: “ [...] a carteira total de projetos do BNDES no setor elétrico somava R $\$ 19,4$ bilhões, o que representa investimentos de $\mathrm{R}$ \$ 31,1 bilhões em geração (com 102 projetos, $17.506 \mathrm{MW}$ de capacidade instalada), transmissão (seis projetos, 4.147 quilômetros de linhas) e distribuição (dezenove projetos)".

Dados mais recentes disponibilizados pela Centrais Elétricas Brasileiras S.A. Eletrobras $^{8}$ apontam a exclusão do Programa Nacional de Desestatização (PND), em 2004, por conta da nova regulamentação do setor. Atualmente, a companhia controla além da Eletrobras Eletronorte, mais 11 subsidiárias: Eletrobras Chesf, Eletrobras Furnas, Eletrobras Eletrosul, Eletrobras CGTEE, Eletrobras Eletronuclear, Eletrobras Distribuição Acre, Eletrobras Amazonas Energia, Eletrobras Distribuição Roraima, Eletrobras Distribuição Rondônia, Eletrobras Distribuição Piauí e Eletrobras Distribuição Alagoas. Somam-se a estas, uma empresa de participações, a Eletrobras Eletropar; um centro de pesquisas, Eletrobras CEPEL; e os $50 \%$ do capital de Itaipu Binacional, representando o governo brasileiro. A Eletrobras tem capacidade instalada para a produção de $41.621 \mathrm{MW}$, incluindo metade da potência da usina Itaipu pertencente ao Brasil, e 56.179 quilômetros de linhas de transmissão em operação, em alta e extra-alta tensão.

\subsubsection{A Eletrobras Eletronorte}

A Centrais Elétricas do Norte do Brasil S.A (Eletronorte) é uma sociedade anônima de economia mista e subsidiária da Eletrobras, que desde 1973 gera e fornece energia elétrica

\footnotetext{
8 Sítio da Eletrobras. Disponível em: http://www.eletrobras.com/elb/data/Pages/LUMISB33DBED6PTBRIE.htm. Acesso em: 12 jan. 2013.
} 
para mais de $60 \%$ da população que habita a região da Amazônia Legal ${ }^{9}$. Sediada no Distrito Federal, a Eletrobras Eletronorte tem como missão "atuar nos mercados de energia de forma integrada, rentável e sustentável” (ELETRONORTE, 2012). Para tanto, cobre uma área equivalente a 5 milhões $\mathrm{km}^{2}$ de floresta, água e natureza, na qual possui quatro hidrelétricas: Tucuruí (PA), considerada a maior usina genuinamente brasileira e a quarta do mundo; Coaracy Nunes (AP); Samuel (RO) e Curuá-Una (PA); para além de parques termelétricos. Com potência total instalada de 9.294,33 MW, possui mais de 9 mil $\mathrm{Km}$ de linhas de transmissão e beneficiam população de mais de 15 milhões, segundo o Censo 2010 do Instituto Brasileiro de Geografia e Estatística - IBGE.

Figura 2 - Unidades Regionais Eletrobras Eletronorte.

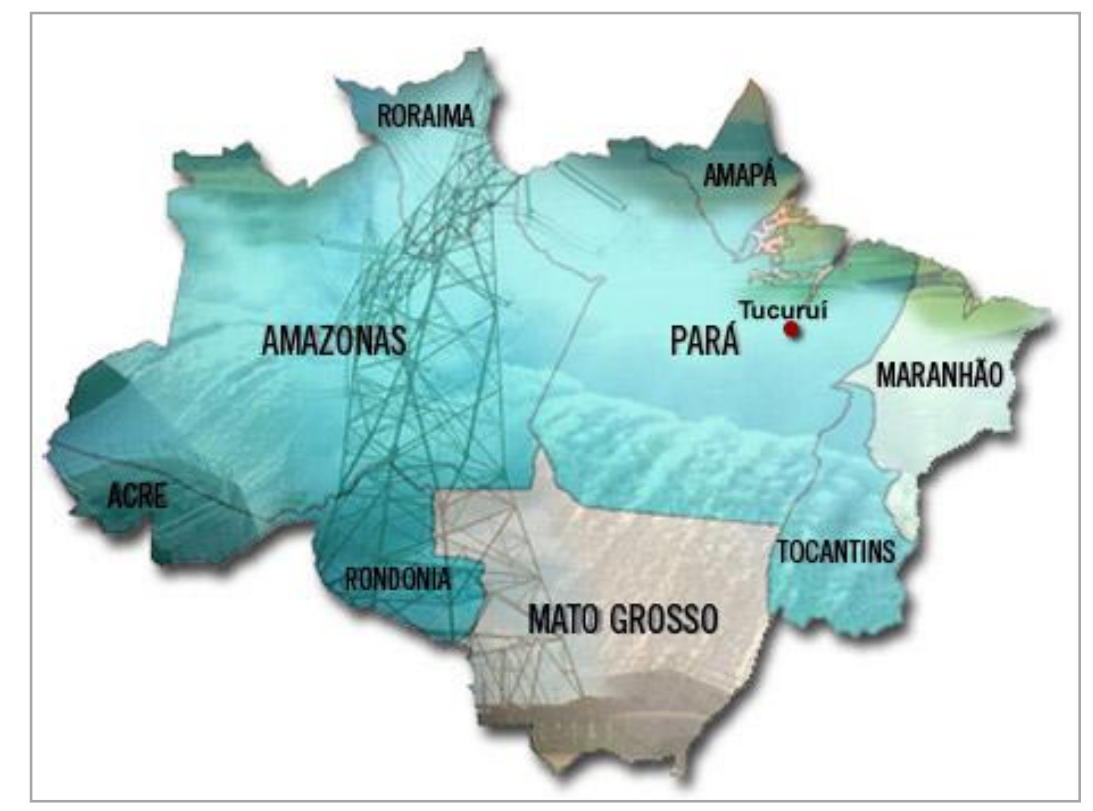

Fonte: Sítio Eletrobras Eletronorte.

A organização completou quatro décadas de funcionamento em junho de 2013. Para continuar competitiva, promover a rentabilidade para os acionistas e atender às exigências do Governo, a Eletrobras Eletronorte possui gestão baseada em desenvolvimento com sustentabilidade, valores essenciais para manutenção do negócio em áreas em que a preservação ambiental e a valorização de mão de obra local são termos demandados pela

\footnotetext{
${ }^{9}$ A Região da Amazônia Legal é composta por nove estados: Acre, Amapá, Amazonas, Maranhão, Mato Grosso, Pará, Rondônia, Roraima e Tocantins.
} 
sociedade e demais públicos-alvo da companhia. Por isso, colaboradores ${ }^{10}$ e gestores monitoram o ambiente organizacional a fim de identificar oportunidades e ameaças que possam interferir no planejamento estratégico e, por conseguinte, no processo operacional (YANAZE, 2006).

Figura 3 - Contexto analisado pelos gestores da Eletrobras Eletronorte.

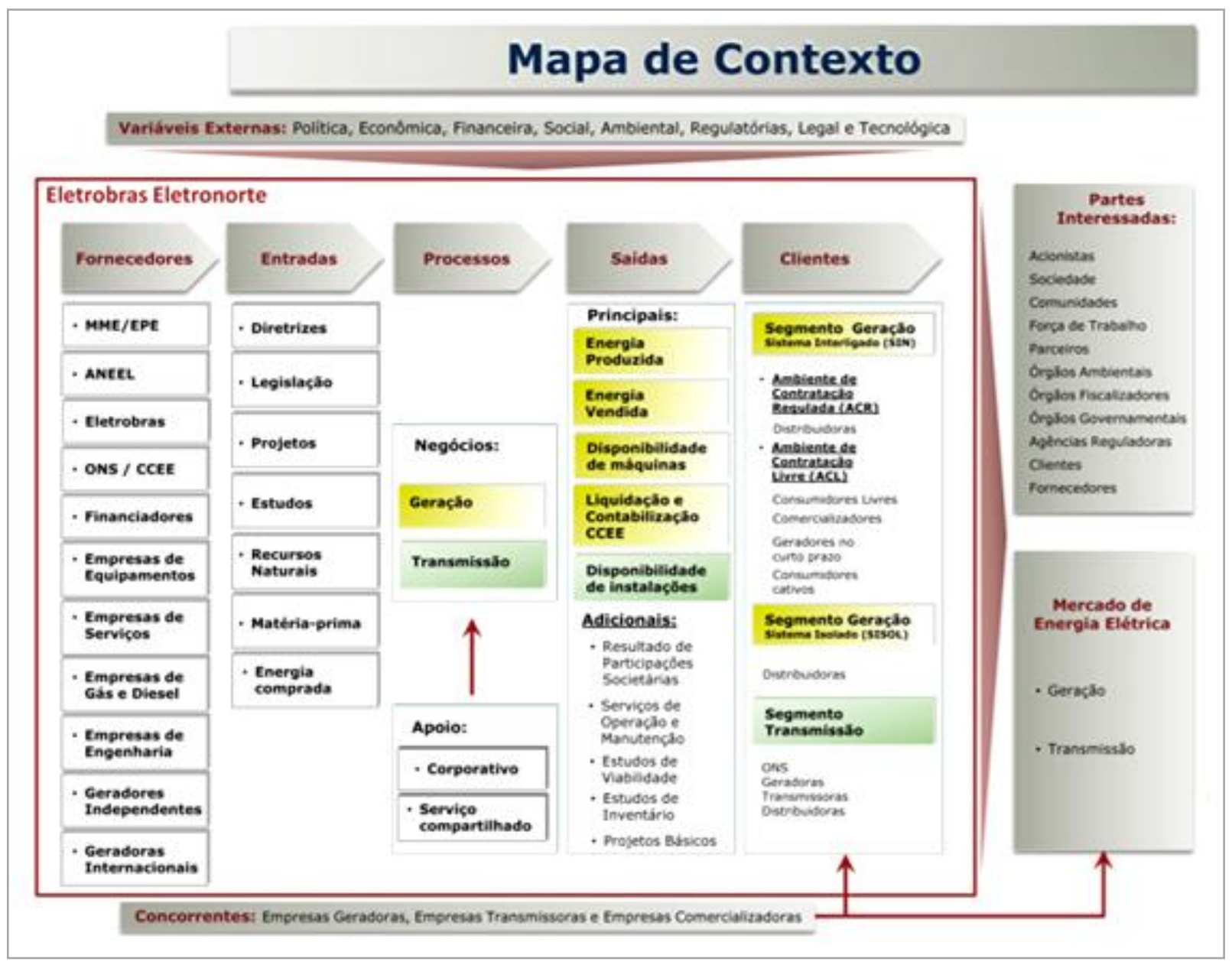

Fonte: Sítio Eletrobras Eletronorte.

Com o intuito de fortalecer as empresas da holding Eletrobras, instituiu-se em 2009 a Política de Pesquisa, Desenvolvimento e Inovação - P\&D+I, com a finalidade de orientar, incentivar e priorizar a pesquisa, o desenvolvimento e a inovação nas empresas Eletrobras. $\mathrm{O}$ processo tem em vista o aumento da interação entre as ações e a capacidade de inovação, devidamente alinhados ao planejamento estratégico e aos planos de negócios dos setores. Diversas políticas estabelecem parâmetros que servem como força motriz para a gestão dos

10 Colaboradores, no contexto do objeto deste estudo, são considerados os empregados, terminologia utilizada pela Eletrobras Eletronorte para seus funcionários, e parceiros, prestadores de serviços ou integrantes de uma das 18 Sociedades de Propósito Específico (SPEs) que a Eletrobras Eletronorte participa. 
processos da organização, tais como a Política de Sustentabilidade, Política de Gestão de Riscos, Política Ambiental, Política de Comunicação Integrada, Política de Eficiência Energética, Política de Logística de Suprimento, Política Integrada de Tecnologia da Informação, dentre outras.

Figura 4 - Sistema de gestão utilizado pelos gestores da Eletrobras Eletronorte.

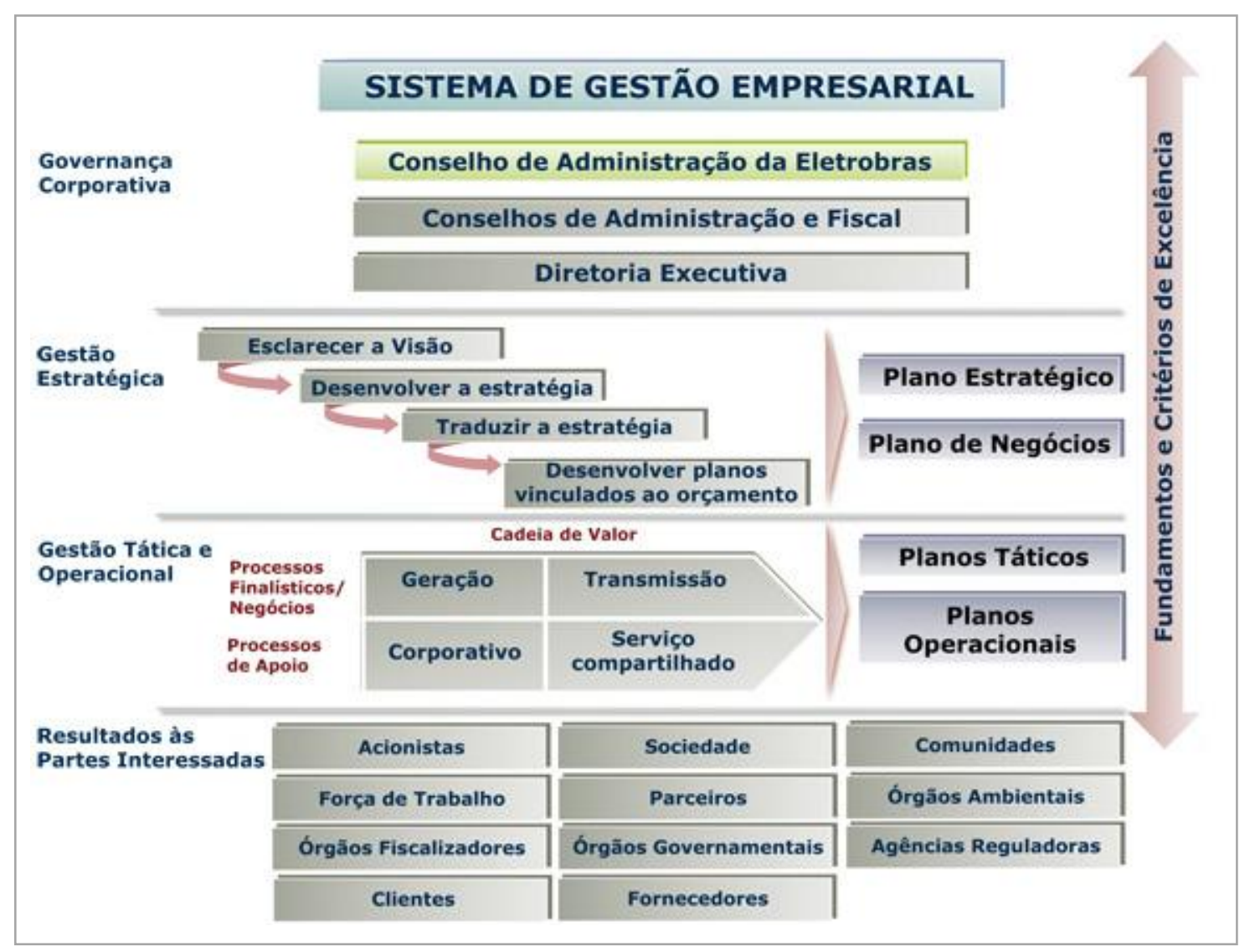

Fonte: Sítio Eletrobras Eletronorte.

A livre circulação da informação estratégica é ponto fundamental para o sucesso da gestão desta organização. Para tanto, a Eletrobras Eletronorte optou por uma plataforma digital que amplia a acessibilidade, disponibilidade e uso da informação ao público-alvo colaboradores, parceiros, fornecedores e demais stakeholders: o Portal do Conhecimento. Vinculado à Assessoria de Educação e Conhecimento - GAE, o portal é destinado, basicamente, à pesquisa da informação técnica, uma vez que as grandes obras de engenharia são o negócio da organização. A ferramenta apresenta grande quantidade de informações, processos, projetos, atividades, ações, serviços e outros recursos que a empresa necessita para desempenhar suas atividades. 
Quadro 1 - Stakeholders da Eletrobras Eletronorte e suas expectativas.

\begin{tabular}{|c|c|}
\hline PARTE INTERESSADA & NECESSIDADES E EXPECTATIVAS \\
\hline Acionistas & $\begin{array}{l}\text { Produtos e serviços; desempenho econômico; satisfaçāo do cliente; } \\
\text { politicas públicas e práticas de investimentos; processos de compras. }\end{array}$ \\
\hline Consumidores - clientes & $\begin{array}{l}\text { Impactos econômicos indiretos; saúde e segurança no trabalho; } \\
\text { satisfação do cliente; conformidade legal. }\end{array}$ \\
\hline Comunidade & $\begin{array}{l}\text { Uso racional e seguro da energia elétrica; água; saúde e segurança } \\
\text { no trabalho; saúde e segurança do cliente; diversidade e igualdade } \\
\text { de oportunidades; comunicaçōes de marketing; trabalho infantil; } \\
\text { impactos econômicos indiretos; liberdade de associaçāo; negociaçāo } \\
\text { coletiva. }\end{array}$ \\
\hline Força de trabalho direta (empregados) & $\begin{array}{l}\text { Desempenho econômico; uso racional e seguro da energia elétrica; } \\
\text { energia; satisfação do cliente; treinamento e educaçāo. }\end{array}$ \\
\hline Demais integrantes da força de trabalho & $\begin{array}{l}\text { Impactos econômicos indiretos; desempenho econômico; emissōes, } \\
\text { efluentes e resíduos; práticas de investimento e processos de } \\
\text { compra; corrupção; treinamento e educação; direitos e deveres do } \\
\text { consumidor; materiais; diversidade e igualdade de oportunidades; } \\
\text { práticas de segurança; uso racional e seguro da energia elétrica; } \\
\text { energia. }\end{array}$ \\
\hline Fornecedores de materiais, equipamentos e serviços & $\begin{array}{l}\text { Desempenho econômico; fornecedores; uso racional e seguro da } \\
\text { energia elétrica; saúde e segurança no trabalho; energia. }\end{array}$ \\
\hline Governo & $\begin{array}{l}\text { Energia; composição da tarifa; desempenho econômico; impactos } \\
\text { econômicos indiretos; políticas públicas; direitos indígenas. }\end{array}$ \\
\hline Outros segmentos & $\begin{array}{l}\text { Água; desempenho econômico; impactos econômicos indiretos; } \\
\text { conformidade legal; relaçōes entre os trabalhadores e a governança. }\end{array}$ \\
\hline
\end{tabular}

Fonte: Eletrobras Eletronorte - Relatório de Sustentabilidade 2012.

Quadro 2 - Sociedades de Propósito Específico (SPEs), parceiros da empresa.

\begin{tabular}{|c|c|}
\hline Sociedade de Propósito Especifico - SPE & Percentual de Participação (\%) \\
\hline AMAZŌNIA ELETRONORTE TRANSMISSORA DE ENERGIA S.A. & 49 \\
\hline AMAPARI ENERGIA S.A. & 49 \\
\hline BRASNORTE TRANSMISSORA DE ENERGIA S.A. & 49,71 \\
\hline BRASVENTOS EOLO GERADORA DE ENERGIA S.A. & 24,5 \\
\hline BRASVENTOS MIASSABA 3 GERADORA DE ENERGIA S.A. & 24,5 \\
\hline $\begin{array}{l}\text { CONSTRUTORA INTEGRAÇĀO LTDA. (Empresa responsável pelo EPC da Norte Brasil Transmissora } \\
\text { de Energia S_A.) }\end{array}$ & 24,5 \\
\hline ENERGÉTICA ÁGUAS DA PEDRA S.A. & 24,5 \\
\hline ESTAÇĀO TRANSMISSORA DE ENERGIA S.A. & 100 \\
\hline INTEGRAÇĀO TRANSMISSORA DE ENERGIA S_A. & 37 \\
\hline LINHA VERDE TRANSMISSORA DE ENERGIA S.A. & 49 \\
\hline $\begin{array}{l}\text { MANAUS CONSTRUTORA LTDA. (Empresa responsável pelo EPC da Manaus Transmissora de } \\
\text { Energia S.A.) }\end{array}$ & 30 \\
\hline MANAUS TRANSMISSORA DE ENERGIA S.A. & 30 \\
\hline NORTE BRASIL TRANSMISSORA DE ENERGIA S.A. & 24,5 \\
\hline NORTE ENERGIA S.A. & 19,98 \\
\hline REI DOS VENTOS 3 GERADORA DE ENERGIA S.A. & 24,5 \\
\hline RIO BRANCO TRANSMISSORA DE ENERGIA S.A. & 100 \\
\hline TRANSMISSORA MATO-GROSSENSE DE ENERGIA S.A. & 49 \\
\hline TRANSNORTE ENERGIA S.A. & 49 \\
\hline
\end{tabular}

Fonte: Eletrobras Eletronorte - Relatório de Sustentabilidade 2012. 


\section{REVISÃO DE LITERATURA}

O presente capítulo trata da revisão de literatura considerando as abordagens sob a ótica da Ciência da Informação, com o objetivo de situar os principais conceitos envolvidos neste trabalho. Em conformidade com a natureza do problema, foi dada ênfase no comportamento de pesquisa da informação com vistas à resolução de problemas.

A revisão de literatura pretende identificar as principais questões estudadas na referida área por meio de levantamentos e análises de artigos, pesquisas, estudos, procedimentos, discussões e conclusões sobre o estado da arte o assunto supracitado.

Com intuito de auxiliar a explanação do problema de pesquisa sob a ótica da disciplina, na primeira parte são apresentadas discussões a respeito da informação e do conhecimento, a importância da informação para as organizações e a interação entre o homem e o ambiente informacional.

Posteriormente, identificam-se aspectos relevantes do comportamento informacional com objetivo de compor a base essencial ao estudo desenvolvido. Questões de busca e uso da informação, necessidades, caminhos e canais de veiculação integram o foco das análises.

Seguem-se discussões sobre a emergência do letramento informacional como base para a interação do usuário e o ambiente de negócios em que está inserido, evidenciando a importância da sistematização do conhecimento de busca e uso da informação.

E, finalizando o debate, apresenta-se o portal corporativo, principais conceitos e vantagens que o tornam ferramenta eficaz em ambientes de grande demanda informacional.

Os assuntos são expostos em blocos distintos, com objetivo de facilitar o encadeamento de ideias do pesquisador e do leitor.

\subsection{A INFORMAÇÃO PARA A TOMADA DE DECISÃO}

\footnotetext{
A informação, seja ela escrita, oral ou audiovisual, vende-se bem. Vende-se cada vez mais e em grande quantidade. [...] É portanto inegável que a informação se industrializa ao se informatizar cada vez mais (LE COADIC, 2004, p. 1).
}

Neste tópico são abordados os conceitos de informação e as abordagens da CI; o papel da informação para o desenvolvimento organizacional com vistas à obtenção de vantagem competitiva; bem como a interação entre o homem e o ambiente informacional.

Informação é um termo polissêmico, cujo conceito varia conforme a abordagem (WERSIG; NEVELING, 1975). De acordo com Briggs e Burke (2006), a palavra de origem 
francesa "enforme, informe", cujo significado "dar forma ou modelar" ajudou a cunhar o termo "sociedade da informação". A ideia era expressar a importância de "dar forma ou modelar" um conjunto de aspectos relacionados à comunicação (tais como conhecimento, notícias, literatura e entretenimento) pertinentes há diversas mídias distintas - impressas ou eletrônicas.

Na Ciência da Informação, por exemplo, Buckland (1991) defende a classificação da "informação-como-processo", quando se refere ao ato de informar; a "informação-comoconhecimento", quando se considera o que é transmitido; ou ainda "informação-como-coisa", termo atribuído a "objetos" (por representarem algo que pode ser comunicado) que compõem um todo informativo, passível de medição. A proposta faz referência aos sistemas capazes de armazenamento e recuperação da informação, tais como algumas variedades de dados, textos, objetos, eventos e documentos. Vale ressaltar uma característica importante da "informaçãocomo-conhecimento" atribuída pelo autor: a intangibilidade. Não se pode acessá-la fisicamente, mas para transmitir conhecimento ou opinião - atributos subjetivos e conceituais - faz-se necessário descrevê-los, transformá-los em signos com significante (SANTAELLA; NÖTH, 1999) e representá-los devidamente em algum suporte. "Qualquer expressão, descrição ou representação seria “informação-como-coisa”, afirma Buckland (1991).

Figura 5 - Sistemas baseados na representação física do conhecimento.

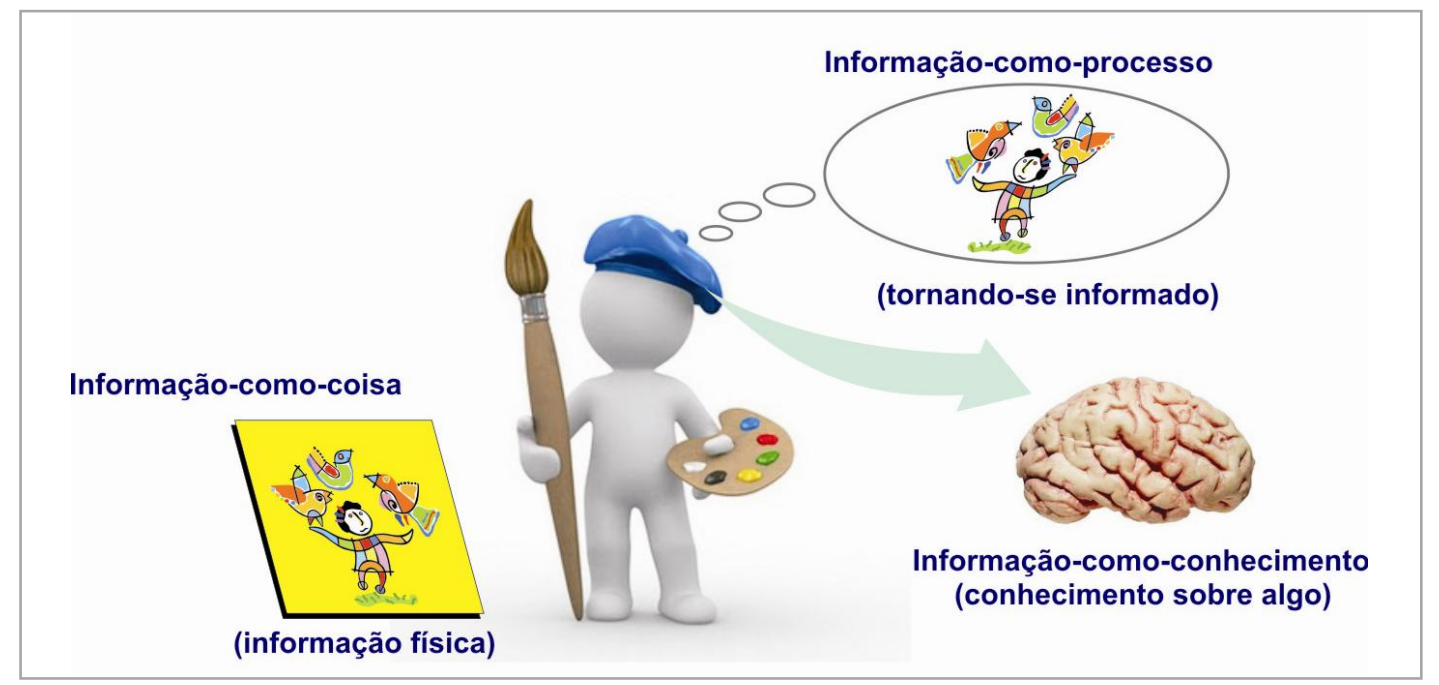

Fonte: adaptado de Buckland (1991).

Le Coadic (2004) denomina informação o conhecimento registrado em forma oral, audiovisual ou escrita - seja ela impressa ou digital - em um suporte, cujo objetivo é dar significado ao que é apreendido pelos sentidos dos seres humanos que dela fazem uso. Em 
outras palavras, o conhecimento, quando registrado em algum suporte, passa a ser informação, e "informação-como-coisa", conforme descrito por Buckland (1991). Os dados são a base da informação, segundo Davenport (2003), que os define como registros ou fatos em "estado bruto", sem tratamento ou interpretação específica. O autor defende a ideia de que se consegue obter informação ao se aglutinar alguns dados, desde que tenham alguma relevância e atendam a um propósito.

A capacidade de atribuir relevância é uma característica essencialmente dos seres humanos, pois são as pessoas que transformam dados em algo útil, isto é, em informação. A tarefa demanda análise, o que a torna mais complexa, pois quem a executa pode pensar diferentemente de outrem, discordar de definições. Davenport (2003) afirma que a informação mais valiosa transforma-se em conhecimento, o que a torna mais difícil de administrar. Isto porque alguém atribuiu algum significado e a incluiu em um determinado contexto, passível de interpretação.

Figura 6 - Conceitos: dados, informação e conhecimento.

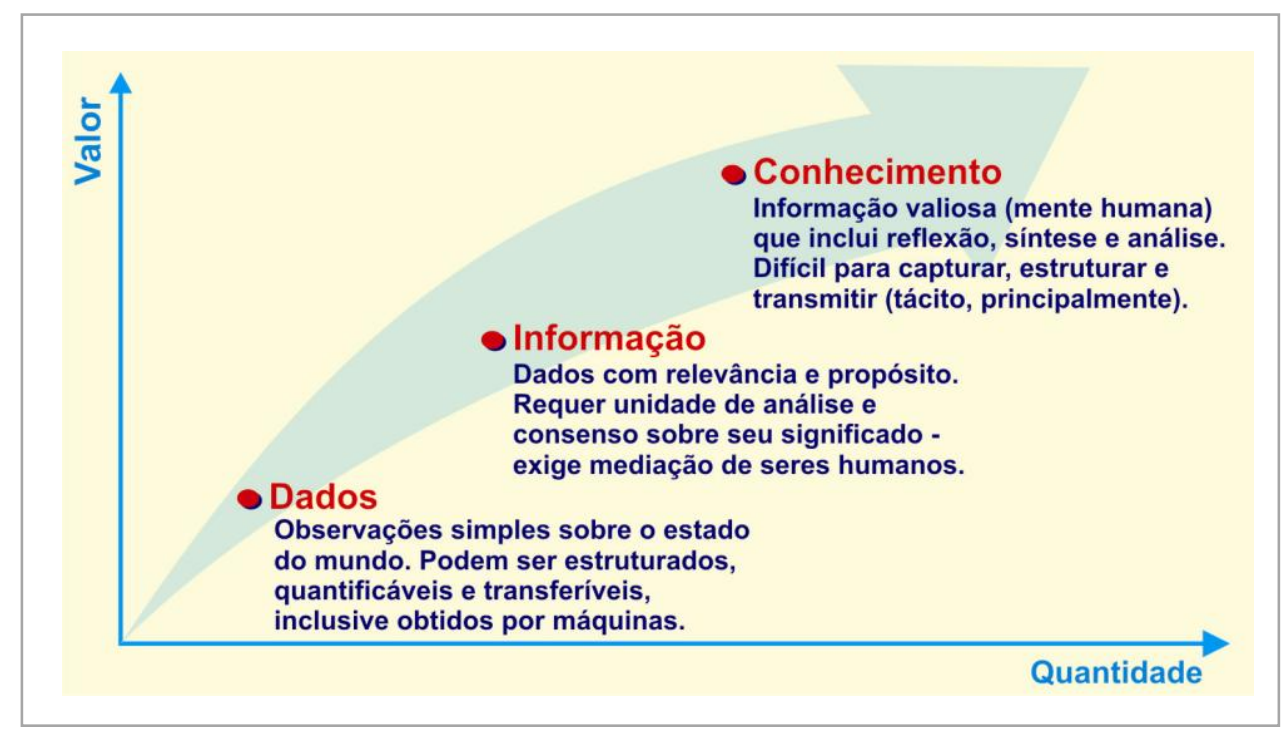

Fonte: adaptado de DAVENPORT (2003, p. 18)

Outra forma de apresentar o conceito de informação é proposta por Brookes (1980), ao descrever a informação como a estrutura que compõe o conhecimento, relação conhecida como "a equação fundamental da ciência da informação". Na verdade, trata-se de equação pseudomatemática $^{11}$, em que o autor mostra a estrutura de conhecimento existente $(\mathrm{K}[\mathrm{S}])$ é

$\overline{11}$ Brookes (1980) utilizou expressão similar a uma equação matemática por achar a maneira mais compacta para explicar a relação entre informação e conhecimento. 
transformada pelo acréscimo de uma informação ( $\Delta$ I ), gerando um novo estado de conhecimento $(K[S+\Delta S])$, em que $\Delta S$ indica a variação na estrutura pré-existente.

Figura 7 - A equação pseudomatemática de Brookes - informação e conhecimento.

$$
\mathrm{K}[\mathrm{S}]+\Delta \mathrm{I}=\mathrm{K}[\mathrm{S}+\Delta \mathrm{S}]
$$

Fonte: adaptada de Brookes (1980) .

Belkin (1978) defende que a informação tem valor reconhecido no processo de tomada de decisão ao reduzir as incertezas. Ou seja, se somada ao conhecimento existente, produzir outro conhecimento, com mais valor, tal e qual descrito por Brookes (1980), e corroborado por BEAL (2007, p. 21): “[...] a qualidade das decisões irá depender tanto da qualidade da informação provida quanto da capacidade dos tomadores de decisão de interpretá-la e usá-la na escolha de melhores alternativas [...]".

Por ser considerada um ativo intangível nas organizações, a informação possui particularidades que, segundo Beal (2007, p. 23 - 27), devem ser levadas em consideração sobre sua gestão. Trata-se de algumas características específicas da informação:

a) $\mathbf{1}^{\mathbf{a}}$ Lei - a informação é (infinitamente) compartilhável, pode ser usada simultaneamente por diversas pessoas sem que seja consumida, multiplicando seu valor. Ao contrário do compartilhamento, a simples replicação da informação só agrega custos (de armazenamento, reinserção, dentre outros);

b) $\mathbf{2}^{\mathbf{a}}$ Lei - o valor da informação aumenta com o uso. Informação não possui depreciação. Assim, quanto mais pessoas a utilizam, mais benefícios terão os usuários. Alguns pré-requisitos para o uso efetivo da informação listados pela autora (BEAL, 2007, p. 24) são: saber que a informação existe; saber onde está armazenada; saber como ter acesso e saber como utilizá-la; saber adaptar o formato da informação às necessidades do usuário, tais como linguagem, complexidade, dentre outros;

c) $3^{\text {a }}$ Lei - a informação é perecível, ou seja, em uma organização, conforme o tempo passa, a informação perde valor. E, de acordo com Yanaze (2006), prontidão é palavra-chave em planejamento estratégico;

d) $4{ }^{\text {a }}$ Lei - o valor da informação aumenta com a precisão. Quanto mais precisa, mais útil poderá ser para a organização; 
e) $5^{\text {a }}$ Lei - o valor da informação aumenta quando há combinação de informações: haja vista os sistemas integrado de gestão empresarial, que visam compartilhar a informação de forma integrada, que viabiliza a visão sistêmica dos processos;

f) $6^{\text {a }}$ Lei - mais informação não é necessariamente melhor. O excesso de informação é um problema para muitas empresas, pois prejudica a interpretação, logo reduz seu valor. A utilidade é definida por critérios identificados pelo usuário, tais como relevância, qualidade da apresentação e quantidade;

g) $7^{\text {a }}$ Lei - a informação se multiplica. É “autogenerativa”, multiplicável por processos como síntese, combinação e análise. A cada nova combinação de dados pode-se obter nova informação - conforme destacado na pseudoequação de Brookes (1980).

Yanaze (2006) corrobora com o referido contexto ao defender que a existência de recursos tecnológicos que viabilizam acesso à informação não garantem sucesso na obtenção da vantagem competitiva. A eficácia no monitoramento do ambiente e na tomada de decisões estratégicas coerentes com os objetivos traçados, depende da disponibilidade de informação relevante, obtida no momento certo, e com grau de detalhamento suficiente para que seja efetivamente útil.

O autor propõe diagrama do processo decisório para a solução de problemas, isto é, como o sistema que a organização deve utilizar para ocasiões em que necessite de decisões que não envolvem a rotina operacional. Contudo, Yanaze (2006) afirma não existir modelo único que possa atender a todas as empresas, em virtude da diversidade e complexidade dos ambientes empresariais nos quais estão inseridos. "Cada uma possui requisitos de informação específicos, relativos a mercados diferentes, competidores diferentes, e prioridades de negócio e estilos de administração particulares" (p. 214). 
Figura 8 - Processo decisório para a solução de problemas.

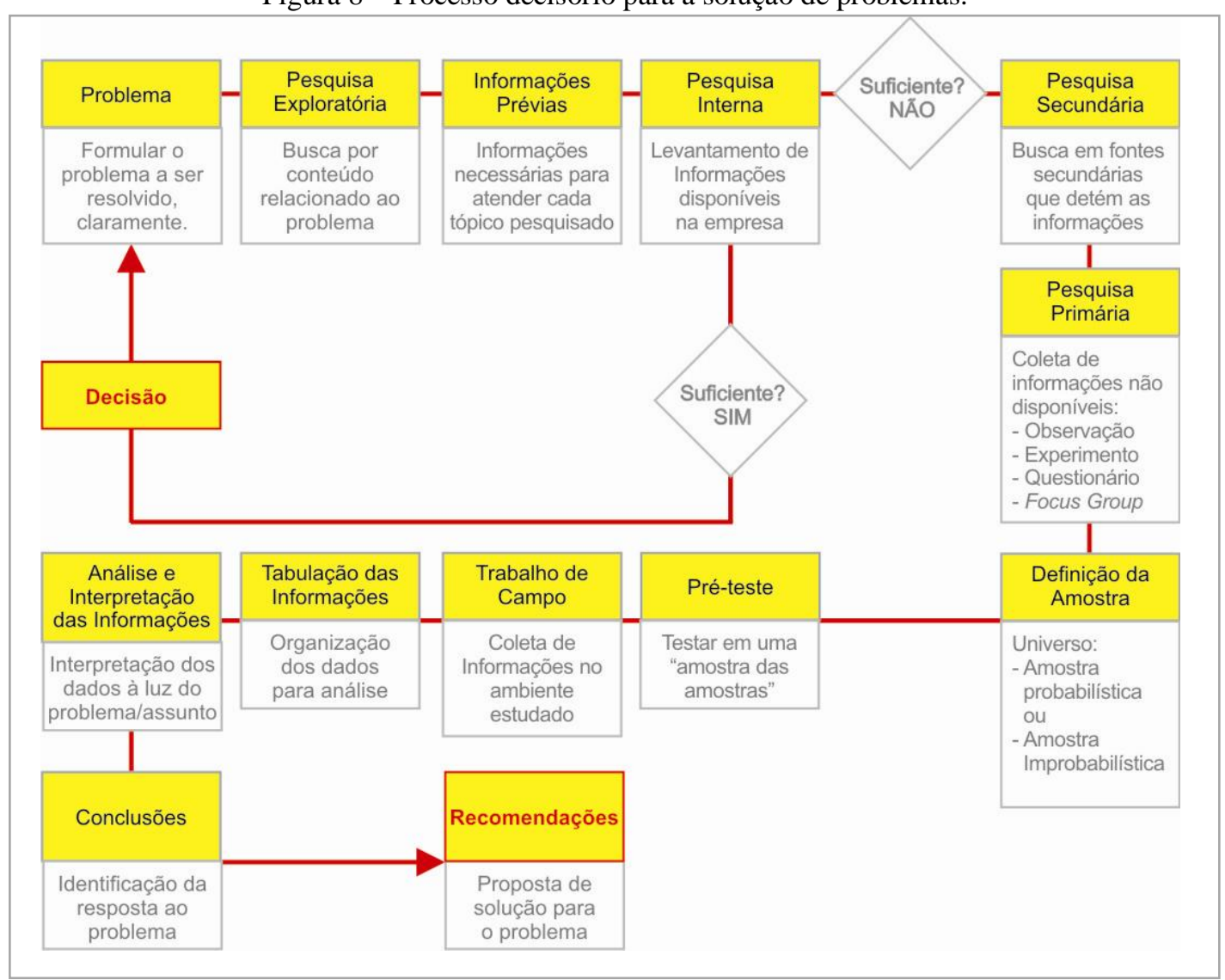

Fonte: adaptado de Yanaze (2006).

Cassarro (2003) apresenta proposta similar, em que a tomada de decisões envolve um processo cíclico, no qual é essencial a existência de informações apropriadas a cada uma das fases, chamado de ciclo de tomada de decisões. O autor infere que a decisão é um processo de escolha de alternativas que atende a critérios previamente estabelecidos, tais como objetivos, programas ou políticas (em planejamento) ou recursos, estrutura e procedimentos (quando se trata de ação organizacional). Ainda, destaca a importância das informações qualificadas em cada fase do processo de tomada de decisão, o que pode resultar em sucesso ou fracasso da decisão no ambiente organizacional. 
Figura 9 - Ciclo de tomada de decisões.

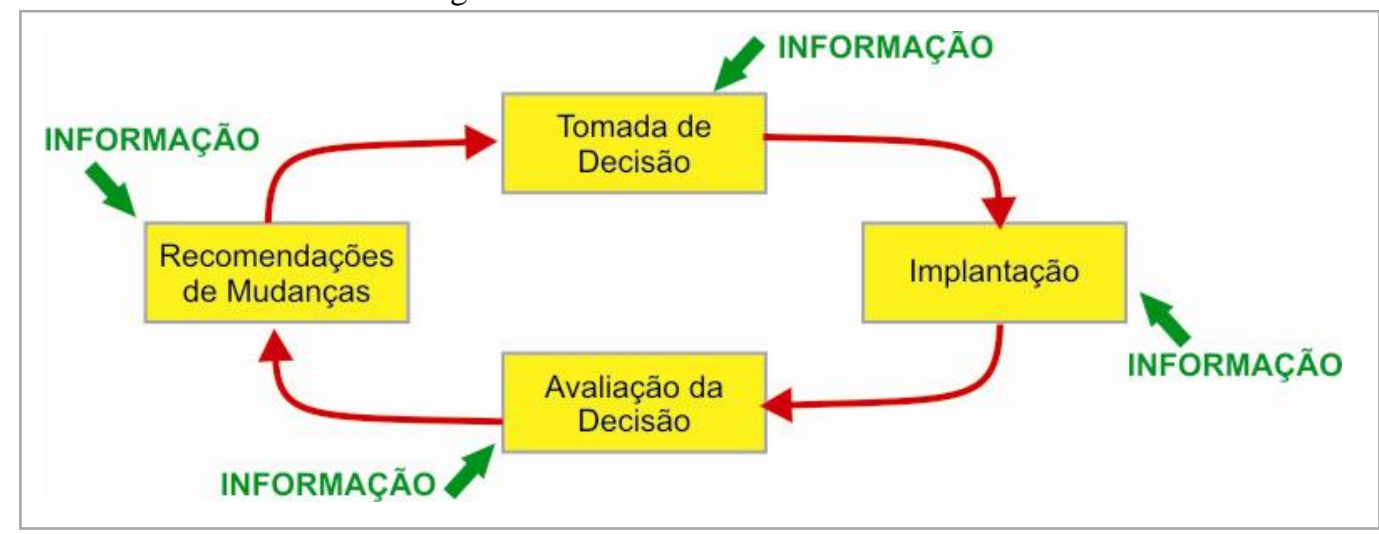

Fonte: Cassarro (2003).

\subsubsection{A informação para o desenvolvimento organizacional}

A informação tem sido objeto de pesquisas em diversas áreas do conhecimento (LE COADIC, 2004). Organizações competitivas encontram dificuldades em transmitir o conhecimento necessário ao desempenho eficaz de operações operacionais ou gerenciais com fidelidade absoluta. Ensinar algo a alguém demanda a transmissão de informação qualificada, classificada, selecionada e, nem por isso será assimilada porque depende do processo cognitivo do receptor e de suas experiências. Choo (2006) ressalta que, quando ocorre interpretação, atribuição de significado e é empregado um contexto a uma informação, esta se transforma em conhecimento e, consequentemente, passa a ter mais valor (para alguém). $\mathrm{O}$ autor destaca que o conhecimento utilizado nas organizações é fruto da atividade de pessoas trabalhando juntas, compartilhando experiências e construindo significados, amparados pelas TICs - que colaboram com a produção, armazenamento e disseminação da informação estratégica para a organização.

\footnotetext{
A informação é um componente intrínseco de quase tudo que uma organização faz. Sem uma clara compreensão dos processos organizacionais e humanos pelos quais a informação se transforma em percepção, conhecimento e ação, as empresas não são capazes de perceber a importância das fontes de tecnologias de informação. (CHOO, 2006, p. 27).
}

A atual percepção de gestão e teoria organizacional evidencia o caráter estratégico da informação para a organização se desenvolver ou se adaptar ao ambiente em que se insere, situação primordial para obter vantagem competitiva (KOTLER, 1999). É tarefa básica para sobrevivência empresarial saber distinguir fatos e mensagens do que ocorre no mercado, bem como identificar tendências (preferencialmente antes da concorrência), sujeitas às 
interpretações diversas (CHOO, 2006). A análise do ambiente é crucial para a elaboração de estratégias competitivas nos negócios, ocasião em que os gestores devem identificar as principais alterações do mercado, adaptando-as às suas possibilidades de realização e capacidade de resposta. Para lidar com a necessidade constante de criação e uso estratégico da informação, o autor defende uma concepção de teoria organizacional embasada na existência de três arenas do uso estratégico da informação:

a) Informação para a criação de significado - quando a informação deve ser direcionada para interpretação do ambiente externo - para identificação das forças oportunidades e ameaças, e a interação com diversos públicos-alvo;

b) Informação para construir conhecimento - as organizações devem gerar, organizar e processar a informação com objetivo de originar conhecimentos inovadores, por meio do aprendizado constante, que resultem no desenvolvimento de novos produtos, otimização dos existentes e incremento dos processos da empresa;

c) Informação para a tomada de decisão - os gestores devem buscar e avaliar as informações para a tomada de decisões relevantes no contexto empresarial - toda ação da empresa é resultante de uma decisão e compromisso para gerar uma ação.

Pode-se constatar que as três arenas estão interligadas e proporcionam visão holística ${ }^{12}$ do uso da informação no ambiente empresarial. A ação organizacional, foco do processo, muda o ambiente por gerar experiências diferentes das pré-existentes e, novamente a organização necessita se adaptar a este novo contexto, o que realimenta o ciclo. Choo (2006) afirma que processar e analisar a informação são as principais tarefas durante a tomada de decisão, pois é a ocasião em que devem ser ponderados os prós e contras de uma ação, a qual deve ser guiada pela política estratégica ${ }^{13}$ da empresa. Logo, uma organização que consiga ser eficiente ao integrar as três arenas do uso da informação pode ser considerada uma organização do conhecimento.

12 Em gestão empresarial, o termo visão holística é empregado para indicar uma imagem única, sintética de todos os elementos da empresa, relacionados a visões parciais abrangendo suas estratégias, atividades, informações, recursos e organização, tais como estrutura da empresa, cultura organizacional, qualificação do pessoal, assim como suas inter-relações (LUIZ, 2009).

13 Na política estratégica da organização deve ser considerado o arsenal que norteia a empresa no ambiente em que atua: visão, missão, objetivos, políticas internas etc. (YANAZE, 2006). 
Figura 10 - Uso da informação no ambiente empresarial.

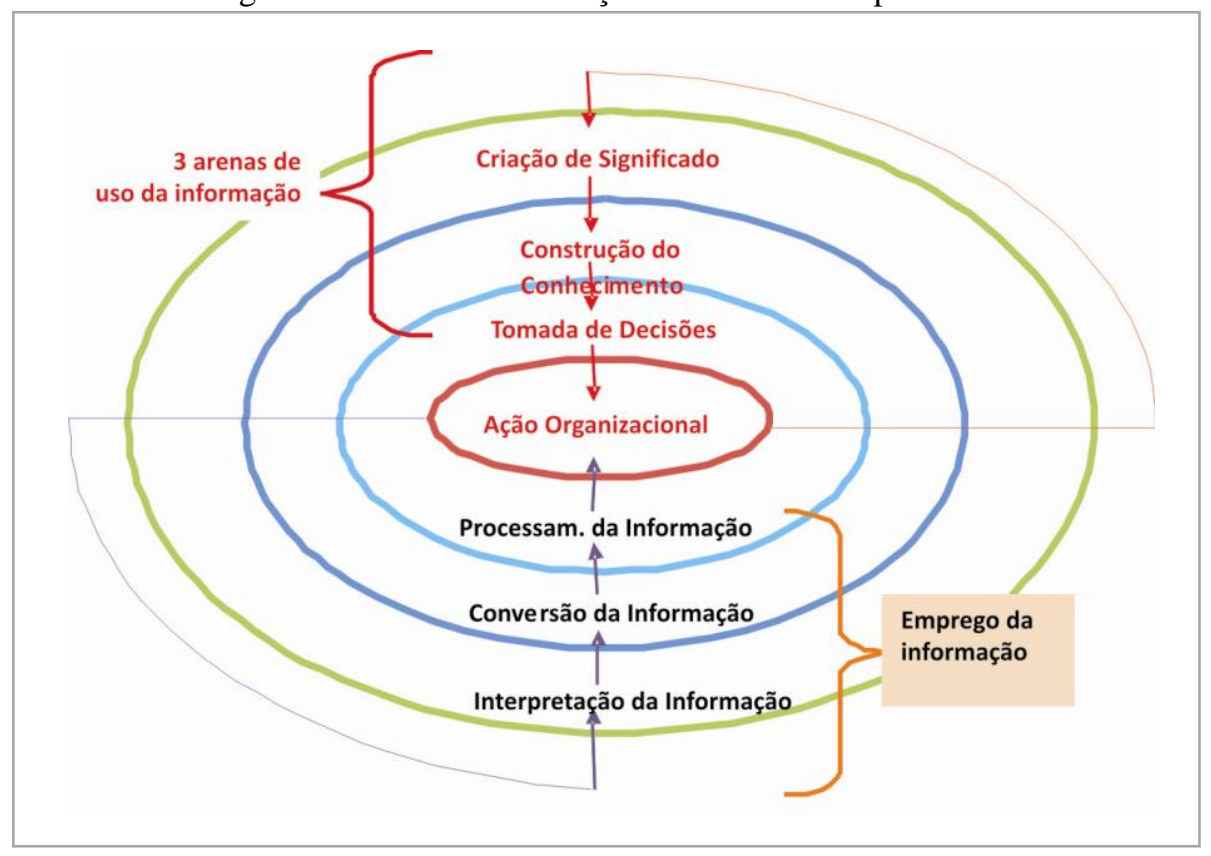

Fonte: adaptado de Choo (2006, p. 31)

Le Coadic (2004, p. 27) afirma que o desenvolvimento econômico atual acontece em virtude do sistema de construção do conhecimento integrado ao sistema econômico e social; a ciência integra-se ao sistema de produção, o produto resultante chega à sociedade. "A industrialização passa pela ciência e a ciência passa pela industrialização".

Para auxiliar a implementação deste processo, o sistema de comunicação da organização viabiliza as trocas de informações entre os ambientes organizacionais. Além disso, responsabiliza-se pelo processamento das funções administrativas internas e dos relacionamentos da empresa com o meio externo (KUNSCH, 2008). As TICs tornam-se ferramentas essenciais para promover a busca, o uso e a disseminação da informação (CHOO, 2006).

De acordo com Davenport (2003), o aumento do uso das TICs é uma realidade indiscutível no ambiente empresarial, mas ela isoladamente nada resolve. $\mathrm{O}$ autor cita, como exemplo, o enorme montante de investimentos que as organizações fazem em banco de dados de alta capacidade. No entanto, ficam rapidamente desatualizados se não houver um sistema que promova a alimentação constante para acompanhar as rápidas mudanças do mercado, fato essencial para as empresas que desejam ser competitivas. Para o sistema funcionar, os profissionais devem estar dispostos a compartilhar o que sabem. Assim, todos saem ganhando: a empresa, por ter mais informação qualificada; os funcionários, por estarem atualizados; e o mercado, por ter produtos e serviços inovadores. Davenport (2003) afirma ser 
essencial estabelecer processos e sistemas de armazenamento, desenvolvimento e compartilhamento de informação entre equipes de especialistas.

A Era da Informação é considerada a era da informação democrática, em referência a abundante, onipresente e barata disponibilidade da informação de forma, e pela forma como tal fato fortalece o consumidor em relação ao mercado, colocando-o em vantagem de escolha diante de ofertas dos comerciantes e seus concorrentes. O poder de mercado tem passado dos comerciantes (quem vende) para os consumidores (quem compra), em um contexto cuja concorrência seria mais ativa, exigindo maior preparo dos profissionais e organizações que buscam não apenas sobreviver, mas irem além e garantirem longevidade ao negócio (SAWHNEY; KOTLER , 2001).

Com a imensa oferta de informação, é essencial para a organização competitiva saber diferenciar a informação qualificada, que agrega valor ao negócio por contribuir com o processo de tomada de decisão, e garanta rapidez no atendimento às demandas do mercado (YANAZE, 2006).

\subsection{2 $\mathrm{O}$ valor da informação para a organização}

O valor da informação para uma organização relaciona-se à sua participação no processo de tomada de decisão, bem como ao produto resultante desse processo, que também agrega valor a outras atividades no processamento da informação para o restante da organização. Por outro lado, o autor afirma que poucas decisões são tomadas com a informação apropriada, pois ora há informação insuficiente, ora há sobrecarga de informação inútil (MORESI, 2000).

Para Moresi (2000), a informação no contexto das organizações tem basicamente duas aplicações: para interpretar os ambientes de negócio e para atuar nestes ambientes. Conforme explicitado por Beal (2007), a informação em uma organização pode tanto ser considerada insumo para formular estratégias (quando advindas das análises ambientais, por exemplo) quanto objeto do planejamento estratégico (disseminação dos planos e projetos resultantes), inclusive simultaneamente. Para tanto, a organização deve centrar esforços na obtenção, tratamento e disseminação da informação mais útil à execução do planejamento estratégico, inclusive adaptando os fluxos informacionais às demandas dos ambientes de negócio.

A atividade máxima de qualquer executivo, independentemente de seu posicionamento hierárquico em uma organização, é a tomada de decisão. Este é o momento no qual ele demonstra toda a sua capacidade de conduzir os seus 
subordinados e sua razão de ser dentro dela. Os executivos passam grande parte do seu tempo estudando o ambiente e procurando identificar as possíveis linhas de ação. A tomada de decisão é muito mais do que o momento final da escolha, sendo um processo complexo de reflexão, investigação e análise. (MORESI, 2000, p. 18).

Se a tomada de decisão dependerá do valor da informação que baseia todo o processo, então, como definir o valor da informação? Para responder a este questionamento, Moresi (2000) propõe considerar os fatores que influenciam a avaliação da informação, tais como: cliente da informação; objetivo da utilização; nível organizacional em que será aplicada; utilidade para os demais clientes e, finalmente os resultados esperados. O autor sintetiza a proposta em uma equação que apresenta a função que define o valor da informação (VI).

Figura 11 - Valor da informação na organização.

\section{VI = função (informação, organização, finalidade, ações e resultados)}

Fonte: Moresi (2000, p. 18).

Em consonância com outros autores abordados neste trabalho, Moresi (2000) defende a importância do volume de dados e informações disponibilizadas "na medida certa" para atender bem aos gestores no processo decisório, visto que, para o autor, a tomada de decisão ultrapassa o momento final da escolha, pois trata-se de processo complexo de reflexão, investigação e análise.

No processo decisório, o volume de informações e dados colocados à disposição do decisor deve ser na medida certa. Se este volume for excessivo, os dados e informações pertinentes à solução do problema serão mascarados por aqueles considerados espúrios. Para resolver este problema, é necessário escalonar a informação em uma hierarquia capaz de diferenciar as necessidades nas diversas situações, o que reforça a importância de reconhecer que a informação possui valor. (MORESI, 2000, p. 18).

Nesta visão, o autor compreende a informação em um contexto de níveis hierárquicos. A proposta é que os dados assumem a classe mais baixa de informação (representam fatos, textos, gráficos, imagens estáticas, sons, etc.). Estes, após coletados nos ambientes interno e/ou externo, passam por processamento para assumirem forma inteligível para os usuários, ou seja, transformam-se em matéria-prima da produção de informações.

O processo de transformação de dados em informação envolve a aplicação de procedimentos que incluem formatação, tradução, fusão, impressão e assim por diante, processos em grande parte executados automaticamente. Neste nível é passível selecionar as 
informações mediante processo que o autor chamou de "elaboração". Como resultante, as informações incluem características adicionais do problema, geram hipóteses e sugerem soluções para problemas, crítica de argumentos etc. Desta forma, a transformação de dados em informações assume caráter de pré-processamento de um processo de elaboração.

Quando as informações são analisadas e avaliadas em relação à confiabilidade, à relevância e à importância chega-se ao próximo nível: o do conhecimento. Sabe-se que o conhecimento é dinâmico, modifica-se conforme as interações com o ambiente, processo chamado aprendizado (MORESI, 2000). É justamente por meio do conhecimento que os gestores buscam a compreensão mais efetiva do problema a ser solucionado.

[...] O aprendizado é a integração de novas informações em estruturas de conhecimento, de modo a torná-las potencialmente utilizáveis em processos futuros de processamento e de elaboração. Além disto, conhecimentos novos podem resultar de um processo de inferência na própria estrutura do conhecimento (MORESI, 2000, p. 19).

No topo da hierarquia de Moresi (2000), a inteligência é percebida como a informação aliada à oportunidade, ou seja, o conhecimento relevante (em determinado contexto), que viabiliza a atuação com certa vantagem no ambiente considerado. A transformação de conhecimento em inteligência acontece por meio de síntese, habilidade nomeadamente humana baseada em experiência e intuição, que extrapolam a capacidade de qualquer sistema. Para o autor, a experiência agrega valor ao processo decisório da organização, por demonstrar a capacitação para atuar de forma competitiva nos ambientes em que está inserida. 
Figura 12 - Níveis hierárquicos da informação.

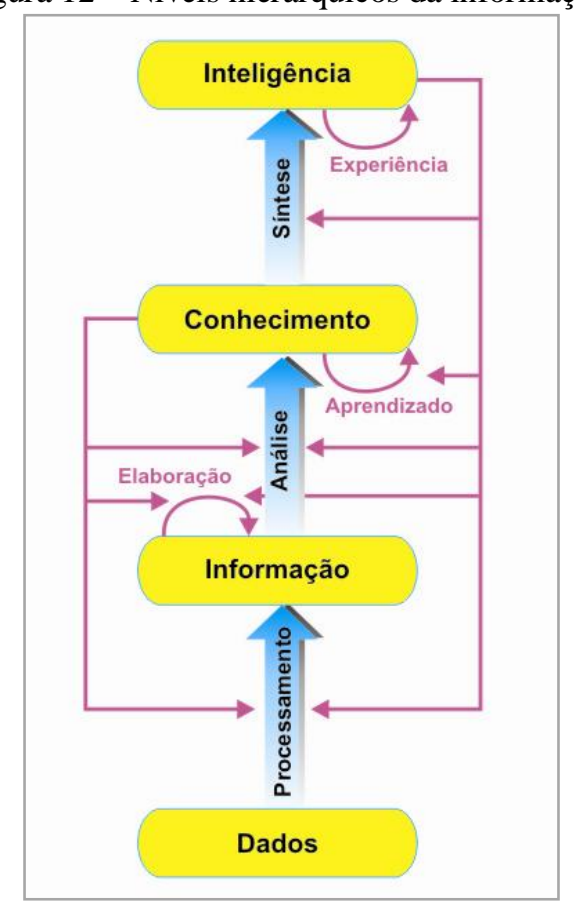

Fonte: Moresi (2000, p. 18).

Segundo o autor, os gestores de altos escalões demandam informação qualitativa, de alto valor agregado que permita obter visão global do ambiente de negócios. Em escalões inferiores, a demanda seria por informação quantitativa de baixo valor agregado, que viabilize o desempenho das tarefas corriqueiras. Por outro lado, cada vez mais gestores requisitam a participação dos demais níveis da instituição para elaboração do planejamento estratégico (YANAZE, 2006), fato importante na qualificação de profissionais na busca e no uso da informação qualificada, visão corroborada por Gasque (2012, p. 68): “Aprender mais e melhor torna-se uma questão crucial para organizações e governos.”

$\mathrm{Na}$ prática, a racionalidade advinda das informações estratégicas entram em choque com os interesses dos administradores, dando lugar a negociações e trocas entre os grupos envolvidos de acordo com as características de cada situação, incluindo a falta de uma informação específica. A tomada de decisões é um processo complexo, porém parte essencial na vida de uma organização. “ [...] toda ação da empresa é provocada por uma decisão, e toda decisão é um compromisso para uma ação", declara Choo (2006, p. 29).

Compartilhar informação estratégica é algo muito interessante na teoria, mas o gerenciamento da informação e do conhecimento são fatores que dependem essencialmente de pessoas, seres complexos por essência, e que não funcionam como sistemas binários. Soma-se o desafio para lidar com sistemas diversos e enorme demanda de informação, o que leva gestores a buscarem uma perspectiva holística, que vá além dos investimentos em tecnologia 
e considere as intensas e constantes variações sociais - cenário apropriado para a Ecologia da Informação, de acordo com Davenport (2003).

\subsubsection{Ecologia da informação: o homem e o ambiente da informação}

Davenport (2003) denominou Ecologia da Informação a interação do homem com o ambiente da informação em sua totalidade, que considera a cultura organizacional; o comportamento informacional e os processos de trabalho; as políticas empresariais (com os prós e contras da transmissão da informação); e a tecnologia (como um meio, e não um fim), com sistemas de informação instalados e que devem atender à demanda dos usuários.

"A ênfase primária não está na geração e na distribuição de enormes quantidades de informação, mas no uso eficiente de uma quantia relativamente pequena", esclarece Davenport (2003, p. 21). Em outras palavras, os gestores que desejam realizar mudanças ou simplesmente acompanhar o mercado - bastante dinâmico - precisam direcionar esforços para compreender como as pessoas geram, distribuem e usam a informação. Caso contrário, o montante investido em tecnologias não terá o uso previsto - a exemplo de vendedores que não acessam corretamente o banco de dados de clientes, portanto, não conseguem fazer ofertas eficazes de produtos e serviços. As máquinas devem ser meras ferramentas, coadjuvantes no processo de gestão, cujos atores principais são os usuários, seres capazes de perceber a importância de cada parte da informação, como processá-la e onde aplicá-la em busca de melhores resultados.

[...]decisões baseadas em dados inúteis têm custado bilhões de dólares em produtos encalhados, em aquisições que não acrescentam lucratividade ao conjunto, em processos redefinidos que não funcionam, em investimentos em instalações ou equipamentos que não produzem (DAVENPORT, 2003, p. 17).

Amaral (2007) compreende a importância da gestão da informação como meio de por ordem na imensurável quantidade de informação, que circula atualmente na sociedade contemporânea, com objetivo de organizar, tratar e disseminar a informação, de forma a agregar-lhe valor, tornando-a capaz de se transformar em insumo essencial para a tomada de decisão e obtenção de resultados eficazes, ampliando assim a vantagem sobre a concorrência. Tal contexto demanda mudanças e reflexões contínuas por parte de seus atores, o que leva às organizações a buscarem meios de compensar perdas e acompanhar a velocidade dessas transformações. A autora sugere que estas mudanças ultrapassem a área econômica, atingindo 
também as áreas social, política e cultural, por exemplo. "Todos esses fatores alteraram o modo de gerenciar pessoas e recursos" (AMARAL, 2007, p.82).

Esta visão é compartilhada também por Davenport (2003, p. 17) que, depois de realizar várias pesquisas na área afirma que o ambiente informacional das empresas tem sido mal administrado por desconsiderarem os fatores humanos em seus projetos. "O volume e a variedade de informação, os múltiplos propósitos a que se destina e as rápidas transformações derrotam até mesmo as mais rigorosas tentativas de planejamento, projeto ou controle”.

Conforme Choo (2006), o conhecimento produzido nas organizações é resultante da atividade das pessoas trabalhando juntas, compartilhando experiências e construindo significados. O ciclo informacional - produção, armazenamento e disseminação da informação estratégica para a organização - completa-se quando há ambiente propício à colaboração, viabilizado com o processo de aprendizado organizacional para a captura, análise e disseminação de informações de forma ágil, otimizando o processo decisório. Sguario e Tomaél (2011) destacam que a Aprendizagem Organizacional (ApO) proporciona a capacidade de uma organização identificar e armazenar o conhecimento oriundo das experiências individuais e dos grupos que a compõe, obtendo mudanças de comportamento dos atores que atuam no ambiente de negócios. Nesse lócus, identificam-se oportunidades inexploradas pelos competidores e também de onde provém informações essenciais aos negócios (YANAZE, 2006).

A ApO é um processo em evidência nas grandes organizações, porque precisam capacitar para atender às novas demandas geradas por um cenário dinâmico e cada vez mais competitivo. Vale salientar que a modernização tecnológica ocorre rápida e intensamente, o que gera processos de atualizações e mudanças em ambientes organizacionais, os quais podem se transformar em ambientes de incertezas e complexidades, aumentando a necessidade da ApO como característica positiva da organização (BEMFICA; BORGES, 1999).

Existem diversas definições para a ApO, inclusive algumas parecem discordarem entre si. Fernandes (1999) comenta que, para os economistas, trata-se da utilização do conhecimento de modo a refletir resultado positivo quantificável. Os administradores compreendem-na relacionada à eficiência competitiva capacidade de inovação. A abordagem utilizada para esse trabalho evidencia a relação com os processos e resultados dentro das organizações, como estas organizam e gerenciam o conhecimento, modificando o ambiente e a cultural organizacional. De acordo com o autor, a troca de conhecimento do conjunto dos 
indivíduos que representam a organização constitui uma ApO, mesmo que cada pessoa, individualmente, não reflita a capacidade de aprendizagem daquela instituição.

Para se conseguir o estado da arte em ApO, Fleury e Fleury (1995) propõem algumas etapas para as organizações:

a) Resolução sistemática de problemas - com diagnósticos elaborados através de métodos científicos usados para a tomada de decisão;

b) Experimentação - constante procura e avaliação científica de novos conhecimentos, que possam gerar novos produtos ou processos, por exemplo;

c) Experiência passada - revisão e avaliação dos resultados de sucesso e fracassos da própria organização;

d) Circulação de conhecimento - circulação rápida e eficiente das novas ideias geradas pela organização, de maneira a aumentar o impacto e a adesão, por serem compartilhadas coletivamente (e não apenas entre os dirigentes);

e) Experiências realizadas por outras organizações - propósito da técnica também conhecida como benchmarking (YANAZE, 2006) que avalia a concorrência identificando pontos fortes e fracos sobre ela.

Com o objetivo de fomentar o processo, a Comunicação Organizacional promove a interação e troca de dados, informações e conhecimentos entre os atores (humanos), máquinas, grupos e setores da organização, inclusive entre esta e o ambiente empresarial em que está inserida. Além disso, promove o aprendizado em equipe, desenvolve competências coletivas e individuais -, ampliando a visão compartilhada e o raciocínio sistêmico (SENGE, 1990).

A Comunicação Organizacional, devidamente planejada, incentiva a efetivação das práticas informais de controle integrando-as às formais. Desta maneira, o conhecimento tácito - referente ao conjunto de valores e formação pessoal de cada indivíduo - converte-se em conhecimento explícito, sendo empregado pelos demais membros de uma organização na realização de suas atividades (CHOO, 2006). Nesse contexto, importam tanto as experiências positivas quanto negativas para a formação do conhecimento organizacional, essenciais para o processo de tomada de decisão.

Para ser capaz de caracterizar experiências e identificar relevâncias nos processos, é necessário que o indivíduo reconheça a informação como insumo essencial para a tomada de decisões eficazes no ambiente de negócios, inclusive perceber quando há necessidade de informação e identificar potenciais fontes e os canais para desenvolver estratégias eficientes 
de pesquisa. Além disso, que é importante compartilhar e acessar com êxito a informação, organizá-la e armazená-la.

A oferta de um produto - seja ele um bem ou serviço - deve ser precedida de demanda, o que tem exigido maior preparo dos profissionais e organizações que buscam não apenas sobreviver, mas irem além e garantirem longevidade ao negócio (SAWHNEY; KOTLER , 2001). Conhecer a necessidade de informação dos usuários permite compreender o motivo das pessoas se envolverem em um processo de busca da informação.

\subsection{COMPORTAMENTO INFORMACIONAL}

O que leva uma pessoa a procurar informação? A existência de um problema a resolver, de um projeto a atingir e a constatação de um estado anômalo de conhecimento, insuficiente ou inadequado. [...] A hipótese subjacente é que os seres humanos têm necessidade de informação da mesma forma que necessitam de alimento ou abrigo (LE COADIC, 2004, p. 39).

O capítulo apresenta questões relevantes da área da ciência da informação a respeito do processo denominado comportamento informacional - a maneira como o ser humano lida com a necessidade da informação, que envolve aspectos de busca e uso da informação. Relacionados ao contexto da pesquisa, apresenta-se a visão de estudiosos sobre o comportamento dos usuários da informação na sociedade de aprendizagem, a evolução e importância dos estudos na área para a ciência da informação e disciplinas afins.

Comportamento informacional designa as ações relacionadas às necessidades de informação que os indivíduos têm, como buscam, usam e transferem-na em diferentes contextos. Isso implica considerar a situação, complexidade das tarefas envolvidas, problemas relacionados, a cultura dos indivíduos envolvidos no processo, além de outros itens que possam ampliar a estrutura teórica da área a ser trabalhada pela informação (GASQUE; COSTA, 2010).

A origem dos estudos remonta à década de 1940, época em que o conceito de informação, como empregado atualmente, em referência ao conhecimento comunicado a outrem, alcançou o status de grande relevância na sociedade contemporânea (CAPURRO; HJØRLAND, 2007). Em virtude da explosão de informações científicas e tecnológicas do período do pós-guerra, diversos estudos acadêmicos foram realizados com o foco na necessidade de planejar e organizar o armazenamento, transmissão e aumento da produção da informação (LE COADIC, 2004), que crescia exponencialmente acompanhando o 
desenvolvimento da economia, proveniente da ampliação do capitalismo e da introdução e uso das TICs, dentre outros fatores (CAPURRO; HJØRLAND, 2007).

O Comportamento Informacional Humano é o termo empregado em pesquisas que evoluíram do campo dos estudos de usuários da informação, área também conhecida como "estudos de necessidades" ${ }^{14}$, assim denominada por abranger o método de pesquisa que considera o estudo das demandas e do emprego da informação para atender às necessidades do indivíduo, transformando-o em usuário da informação (MIRANDA, 2003). As necessidades de informação dos indivíduos se alteram em cada era da história, porém estão associadas ao esforço para gerenciar o contexto presente e futuro, em conformidade com os motivos pessoais, políticos e econômicos (BRIGGS; BURKE, 2006).

Conforme Gasque e Costa (2010), a partir da década de 90, a expressão comportamento informacional (do inglês informational behavior) apresenta maiores ocorrências no Annual Review of Information Science and Technology (ARIST). Contudo, apresenta algumas críticas por possibilitar a interpretação equivocada de que estaria relacionada ao comportamento da informação, e não do usuário da informação. No contexto de estudos de comportamento informacional, o termo informação é utilizado para designar uma entidade física ou fenômeno, como no caso de questões relacionadas com o número de livros lidos num período de tempo, o número de publicações subscritas a , etc., o canal de comunicação por meio do qual as mensagens são transferidas - informação oral versus escrita -, ou os dados factuais, determinados empiricamente e apresentados em documento ou transmitidos oralmente. Martinez-Silveira e Oddone (2007) afirmam que, a falta da informação ou o simples ato de desejá-la não caracterizam uma necessidade de informação. Para isso, é necessário que o indivíduo tenha um objetivo em mente, e que a informação colabore efetivamente para atendê-lo.

No caso dos engenheiros, que trabalham em ampla gama de ambientes, suas necessidades informacionais perfilam-se pela ênfase de sua atividade que, geralmente, é a solução de problemas técnicos. O resultado do seu trabalho tende a ser um produto, um processo ou um serviço, mais do que um novo conhecimento em si. Por isto, os engenheiros

14 Em estudo realizado por Gasque e Costa (2010) no catálogo on-line do IBICT, nas bases LISA, ERIC e no buscador Scirus, os termos "comportamento informacional", "busca e uso da informação", "necessidades de informação" e "estudos de usuários" têm sido utilizados como sinônimos por acadêmicos da área. Destes, destacava-se (na época) o termo "necessidades de informação", fato que a autora atribui à tradição dos trabalhos iniciais que focavam a necessidade de usuários. No entanto, a autora afirma que o termo "comportamento informacional" tem sido empregado de forma mais intensa, motivo pelo qual será utilizado neste trabalho. 
necessitam de muito mais informação do que a que eles produzem, e essa informação deve ser precisa, atualizada e segura, mas também original (MARTINEZ-SILVEIRA; ODDONE, 2007, p. 120).

Outros fator necessário para compreensão do comportamento informacional relacionase à distinção entre informação e conhecimento. A informação sobre algo pode ser registrada e transmitida a outrem, como destaca Wilson (2000). Por outro lado, o autor defende que o que acontece na mente de cada indivíduo é um fato subjetivo e, por isso, não está facilmente acessível ao observador. No entanto, pode-se identificar tais ocorrências por dedução, pelo comportamento do indivíduo ou por manifestação e exposição das ideias e desejos por vontade própria. Sob este ângulo, o autor propõe a evolução do termo de estudos de usuários para estudos de necessidade e uso, como uma perspectiva mais abrangente que envolve a complexidade do comportamento humano. Por conseguinte, sugere o uso do termo comportamento informacional e a adoção de subcategorias de atividades de busca, uso e transferência da informação, assim definidas:

a) Comportamento informacional - abrange o todo do comportamento humano, relacionado às fontes e canais de informação, que inclui as buscas ativa e passiva de informação e o uso da informação.

b) Comportamento de busca da informação - busca intencional de informações como consequência da necessidade de satisfazer algum objetivo. Ao realizar a busca, o usuário pode selecionar meios para interagir com sistemas de informação manual, revista ou livro, por exemplo; ou com os sistemas baseados em computador, como a internet ou o sistema de gestão da empresa em que trabalha.

c) Comportamento de pesquisa da informação - nível micro do comportamento que analisa o indivíduo como usuário de diversos sistemas de informação. Isto é, abrange a interação homem-máquina, por exemplo, o uso do mouse e seleção de links de interesse; ou questões mais intelectuais como a adoção de estratégia de busca booleana ou determinação de critérios de seleção entre dois livros selecionados. Em ambos os casos há o envolvimento de atos mentais, como o julgamento da relevância dos dados ou informações recuperadas;

d) Comportamento de uso da informação - refere-se às ações físicas e mentais relacionadas à incorporação da informação recém-adquirida aos conhecimentos previamente existentes do usuário. O ato físico ocorre, por exemplo, quando o usuário seleciona parte de um texto para destacar algo relevante. Da mesma 
forma, existem alguns atos mentais no processo, quando o usuário compara as novas informações com o conhecimento que ele já detinha.

Figura 13 - Subcategorias do comportamento informacional.

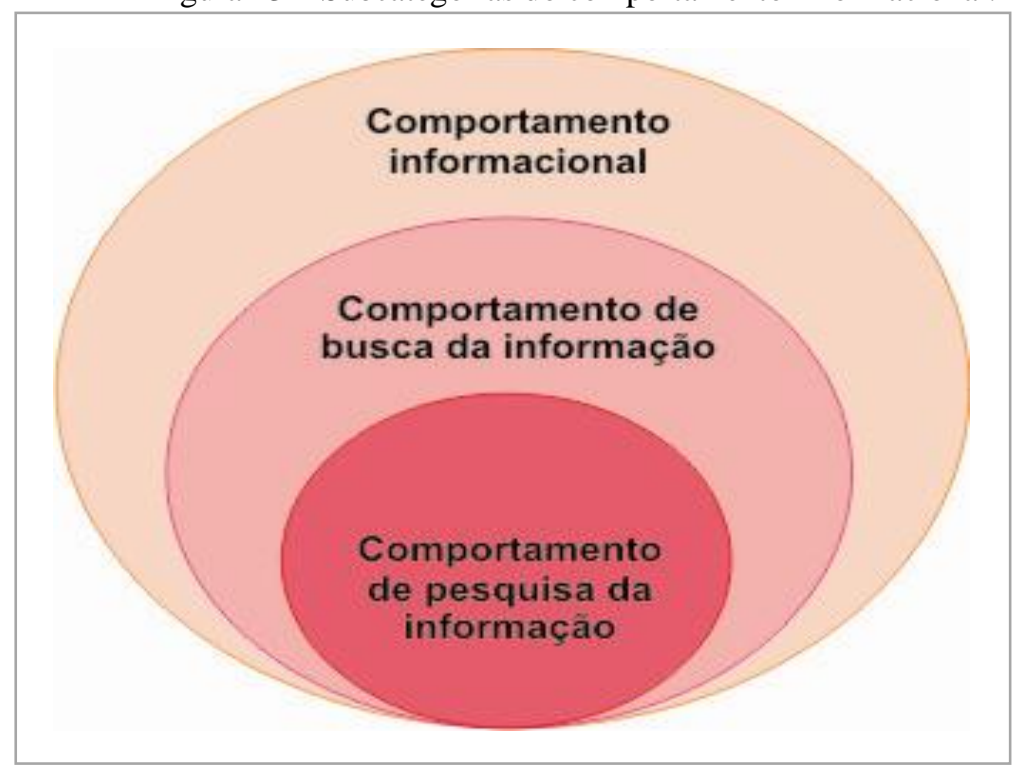

Fonte: Wilson (2000).

Um ponto importante para os estudos do comportamento informacional é o conceito de contexto, espaço-tempo onde ocorrem as ações que envolvem as necessidades dos usuários e de como buscam, usam e transferem a informação (WILSON, 2000). O contexto é uma variável que afeta diretamente o comportamento do usuário da informação, uma vez que a busca por informação se dá em diversos contextos (COURTRIGHT, 2007). A ideia de contexto relaciona-se com a análise do comportamento informacional sob a perspectiva centrada no usuário. Courtright (2007) argumenta que os estudos de comportamento informacional podem ser compreendidos de acordo com quatro contextos, quais sejam:

a) Contêiner - abstração utilizada para explicar que os elementos analisados estão dispostos ao redor dos usuários envolvidos no processo;

b) Construção de significado - enfatiza o ponto de vista do autor, como ele percebe e constrói as influências sobre as ações da informação;

c) Construção social - os atores são seres sociais que constroem informação a partir da interação com outras pessoas e não apenas com o que tem em suas mentes;

d) Relacional - o ator social, usuário da informação e toda sua complexidade, está vinculado ao contexto.

Sistemas e usuários estão inseridos em contextos históricos e sociais e sofrem influência na definiçãa de suas características. Nesta visão, o contexto é tão importante quanto 
as estruturas cognitivas dos usuários ou as características dos sistemas de informação, mecânicas e operacionais. Desta forma, os usuários passam a ser considerados seres que pensam e que se relacionam a um contexto de ação, e que podem ser influenciados ou limitados pelos sistemas de informação que os servem (MARTINEZ-SILVEIRA; ODDONE, 2007).

Courtright (2007) considera ainda a influência de variáveis externas que associadas a outros fatores, devem ser consideradas nos estudos de comportamento informacional ao se analisar o contexto, quais sejam:

a) Institucionais e tecnológicos, ambos considerados variáveis externas que influenciam a ação, tais como o papel desempenhado pelo usuário;

b) Os recursos de informação à disposição dos atores, como bibliotecas, livrarias e agências de informação, por exemplo;

c) O meio cultural e os fatores sociais, como a rede e capital social, normas e colaboração no trabalho;

d) Demais aspectos relacionados a ações, problemas, situações e tecnologias disponíveis; dentre outros.

Na visão de Wilson (1981), o contexto pode gerar necessidades de informação nos indivíduos, a partir do papel que desempenha no atendimento às exigências profissionais ou pessoais; bem como os ambientes - político, econômico, tecnológico, dentre outros - dentro dos quais se desenvolve a vida ou o trabalho do indivíduo. $\mathrm{O}$ autor sugere que, as barreiras que impedem a busca de informações surgem a partir do mesmo conjunto de contextos, que podem influenciar a busca, como facilitadores.

$\mathrm{Na}$ era da economia voltada à informação, é concebível que as necessidades informacionais dos indivíduos estejam relacionadas às atividades profissionais, além das influências por questões pessoais. Segundo Martinez-Silveira e Oddone (2007), algumas variáveis interferem na necessidade de informação, determinando ou mesmo dimensionandoas, quais sejam:

a) Variáveis relacionadas a aspectos demográficos - a idade, profissão, especialização, localização geográfica, dentre outros;

b) Variáveis relacionadas ao contexto - a situação que exige determinada necessidade;

c) Variáveis relacionadas à frequência - se a necessidade é recorrente ou recente;

d) Variáveis relacionadas à capacidade de prevê-la - se a necessidade foi antecipada ou é algo que surgiu de maneira inesperada; 
e) Variáveis relacionadas à importância - em conformidade com o grau de urgência;

f) Variáveis relacionadas à complexidade - a que pode ser facilmente resolvida ou parece ser de difícil solução.

Assim, pode-se concluir que o contexto exerce forte influência na definição do comportamento informacional e que existem diversas variáveis que influenciam a necessidade de informação. Além do contexto, Martinez-Silveira e Oddone (2007, p. 122) indicam outro fator a ser considerado: "o que parece ser determinante na percepção da necessidade, na escolha das fontes de informação e na decisão de efetivamente buscar a informação não é exatamente a disponibilidade dos recursos e sim os processos cognitivos." As necessidades cognitivas, associadas às necessidades fisiológicas e afetivas dos indivíduos integram o modelo de comportamento informacional proposto por Wilson (1981), concebido na época de mudança do paradigma nos estudos sobre comportamento e necessidades informacionais. A partir da década de 80 , houve maior ênfase na participação do usuário no processo de transferência da informação.

A literatura científica apresenta diversos trabalhos centrados no indivíduo, usuário da informação. Além da Ciência da Informação, outras disciplinas como a Ciência da Computação, Comunicação, Administração e Sociologia, mesmo com diferentes enfoques, também empenham-se em pesquisar o comportamento dos usuários da informação - como buscam, transferem, apreendem e empregam a informação (FAUAT, 2007). Mas, nem sempre o usuário foi a parte central das pesquisas na área de comportamento informacional. A evolução dos estudos de necessidades de usuários partiu de preocupações relacionadas aos sistemas de informação e, 30 anos depois, começou a se consolidar no paradigma centrado no indivíduo (COURTRIGHT, 2007).

\subsubsection{Evolução do comportamento informacional}

Os estudos precursores no campo de estudos de usuários datam da década de 1940, como já explicitado neste estudo. De acordo com Gasque e Costa $(2010)^{15}$, dois eventos impulsionaram os interesses de cientistas e tecnólogos no período de explosão informacional do pós-guerra: a Conferência de Informação Científica da Sociedade Real, em 1948, no Reino

15 Gasque e Costa (2010) apresentam a evolução teórica e metodológica dos estudos de comportamento informacional de usuários com base em como são tratados na literatura da ciência da informação, abordando 60 anos de revisão de literatura desde o reconhecimento do termo. 
Unido; e o segundo, realizado 10 anos depois, a Conferência Internacional de Informação Científica, em Washington, EUA. As autoras indicam que as pesquisas realizadas no período de 1950-1960 estavam centradas nos indivíduos que utilizavam informação científica e tecnológica, e se referiam a um conjunto restrito de assuntos com seus respectivos membros cientistas e técnicos. As investigações possuíam abordagem generalista, centrados nos sistemas de informação, ou seja, eram de natureza exploratória e apresentavam resultados descritos em termos gerais, apesar de provenientes de hábitos e necessidades. No entanto, foram essenciais por viabilizarem o esboço de sistemas de informação, considerando a maioria das necessidades dos usuários da época.

Outro aspecto importante, considerado marco decisivo para a área, foi a criação do Centre for Research on User Studies na Universidade de Sheffield, Inglaterra, que em 1976, reuniu especialistas com a missão de transformá-lo em um núcleo nacional de expertise em estudos de usuários, que trabalharia quatro áreas integradas: pesquisa, educação, consultoria e informação. Vale salientar que, no contexto atual, os estudos envolvem colaboradores de diversas partes do mundo e diferenciadas áreas de conhecimento, não estando restritos a cientistas e técnicos (GASQUE; COSTA, 2010).

Pode-se considerar que, ao longo de cinco décadas, ocorreu considerável evolução do estudo de necessidades de usuários, que anteriormente centralizava as pesquisas em sistemas de informação, em que as investigações buscavam respostas para a eficácia dos sistemas e dos mecanismos de recuperação de informação. O cenário alterou-se com o advento da automação das tarefas relacionadas aos documentos, que mudou a percepção sobre o papel do usuário com as máquinas, tornando-se beneficiário direto dos sistemas (MARTINEZ-SILVEIRA; ODDONE, 2007).

A mudança do paradigma, com foco dos estudos nos usuários, também alterou a preocupação dos pesquisadores para captação da informação subjetiva, como é chamada a informação que está na mente do usuário e que se torna útil quando lhe é apropriado um sentido (CHOO, 2006). Desta feita, as pesquisas de comportamento informacional passam a investigar interesses, necessidades e maneiras de busca e uso da informação, e a transferência da informação, aspectos de enorme relevância para as organizações no cenário econômico globalizado.

Na última década, houve grande ampliação dos contextos de estudos, abrangendo, por exemplo, organizações, comunidades, empresas, além dos contextos acadêmico ou industrial. Gasque e Costa (2010) constatam que os estudos de comportamento informacional 
desenvolvidos na Ciência da Informação evoluíram substancialmente desde o início e podem ser caracterizados por:

a) Pesquisas centradas no indivíduo, com inclusão de outros grupos estudados, para além dos cientistas e tecnólogos;

b) Abordagem que privilegia várias facetas, envolvendo aspectos sociocognitivos e organizacional;

c) Compreensão de que o comportamento informacional é um processo, em que há constantes ações de buscas e usos da informação;

d) A ampliação nos estudos qualitativos e o emprego de métodos variados, geraram maior consistência para as teorias desenvolvidas, inclusive com fundamentação interdisciplinar; e,

e) A ampliação da quantidade de pesquisas, com contribuições advindas de diversas disciplinas e variadas localidades geográficas.

Pode-se constatar que o surgimento da internet contribuiu decisivamente para o desenvolvimento do comportamento informacional do indivíduo. A interatividade, proporcionada pelos recursos multimídias da web, fomentou a comunicação entre os usuários e popularizou o uso de ferramentas para compartilhamento de arquivos, publicação de conteúdo, fotos. No entanto, com o excesso e variedade de informações disponíveis, surgem questões sobre como pesquisar eficaz e eficientemente, particularmente quando se refere ao ambiente empresarial onde são desejáveis soluções rápidas e eficaz (ABE; CUNHA, 2011).

\subsubsection{Comportamento de pesquisa da informação}

Na construção do conhecimento, as necessidades de informação surgem de lacunas
do conhecimento, na compreensão ou nas capacidades da organização. Essas lacunas
podem estar na maneira como a organização soluciona um problema ou aproveita
uma oportunidade. [...] Para reduzir o alto nível de incerteza e ambiguidade inerente
à busca de novos conhecimentos, o processo de busca da informação é guiado por
crenças e pressupostos sobre que áreas de desenvolvimento de conhecimentos serão
vantajosas para a organização, que áreas serão plausíveis ou não, assim como quanto
esforço será necessário. (CHOO, 2006, p. 231).

Como tratado anteriormente, o comportamento de pesquisa da informação constitui-se o nível micro do comportamento informacional humano, e está relacionado à forma como os indivíduos interagem com sistemas de informação (WILSON, 2000). O tópico de estudo torna-se extremamente relevante e pertinente ao reconhecer que a internet é, atualmente, fonte 
de informação para milhões de usuários, e que saber usá-la eficaz e eficientemente parece ser um grande desafio para indivíduos e organizações.

Em recente reportagem, Petry (2012, p. 158) enfatiza a necessidade de preparar os profissionais para lidar com o grande volume de informação existente. "O excesso de informação é tal que os novos gênios serão banais, sem originalidade. A genialidade estará no domínio e distribuição da informação, não na sua reinvenção". Tal opinião é compartilhada também por Davenport (2003), que destaca que o quadro fica mais complexo quando são consideradas, no cenário atual, as constantes necessidades de informação para a tomada de decisão, que demandam informação qualificada e prontidão de acesso. O autor reforça que a complexidade está no lado humano da informação, que considera as necessidades fisiológicas, cognitivas e afetivas dos indivíduos, usuários da informação. Tal visão contrapõe-se à formação essencialmente tecnicista das escolas de engenharia, em que projetos informacionais elencam sistemas de informação que não consideram suficientemente as necessidades do indivíduo, o que reflete diretamente nas organizações, na forma de ambiente informacional mal administrado e com resultados financeiros e econômicos diferentes do planejado.

Tradicionalmente, o fluxo da informação nas organizações inicia-se pelo levantamento de necessidades e definição de requisitos de informação, o qual pode-se (ou não) definir um ciclo de coleta, tratamento, distribuição e/ou armazenamento, culminando no emprego da informação, de forma contínua, com objetivo de servir aos propósitos da organização, quais sejam, estratégicos/decisórios ou táticos/operacionais. Parte deste processo funciona para busca de informação do ambiente externo e outra parte fornece informação, processo de troca constante de informação entre a empresa e o ambiente de negócios (BEAL, 2007). 
Figura 14 - Fluxo de informação nas organizações.

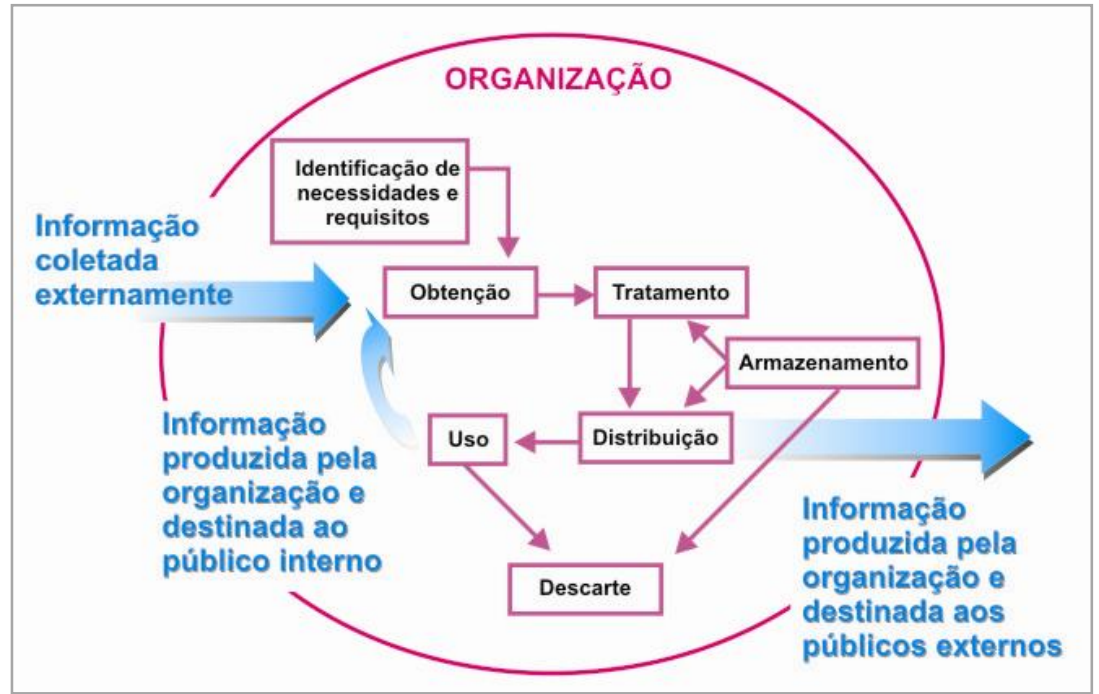

Fonte: Beal (2007, p. 29).

O fluxo da informação na empresa requer organização para tornar-se acessível, particularmente por aqueles que precisam tomar decisões e resolver problemas. Nesse sentido, compreender o processo de pesquisa de informação nas bases de dados empresariais é de suma importância para obtenção de vantagem competitiva. Choo (2006) defende que cabe à organização o papel de definir premissas que orientem à tomada de decisão e integrem o ambiente organizacional, criar ambiente com o máximo de afinidade entre o indivíduo e os objetivos da organização, conquistando a racionalidade nas decisões e a redução de incertezas pela aplicação de rotinas, regras e princípios heurísticos. De acordo com o autor, ao inovar, as organizações tanto processam a informação de fora para dentro, para resolver problemas existentes e adaptar-se ao ambiente mutável de negócios, quanto criam novas informações e conhecimento de dentro para fora, reconfigurando os problemas e as soluções e, desta forma recriam o ambiente em que estão inseridas.

O modelo de comportamento de busca da informação delineado por Wilson, em 1981, apresenta os fatores que influenciam o processo da busca de informação, a partir do reconhecimento de alguma necessidade percebida pelo usuário. De acordo com o autor, o comportamento pode ter várias formas, como por exemplo, o usuário pode fazer exigências nos sistemas formais, como sistemas de informação, ou em sistemas que possam executar funções de informação, tais como empresas ou setores que podem fornecer informações sobre preços, produtos, mercado, ou similares. Percebe-se que o autor associou o conceito de pesquisa da informação a seu modelo de comportamento de busca da informação. 
Figura 15 - Modelo de comportamento informacional de Wilson.

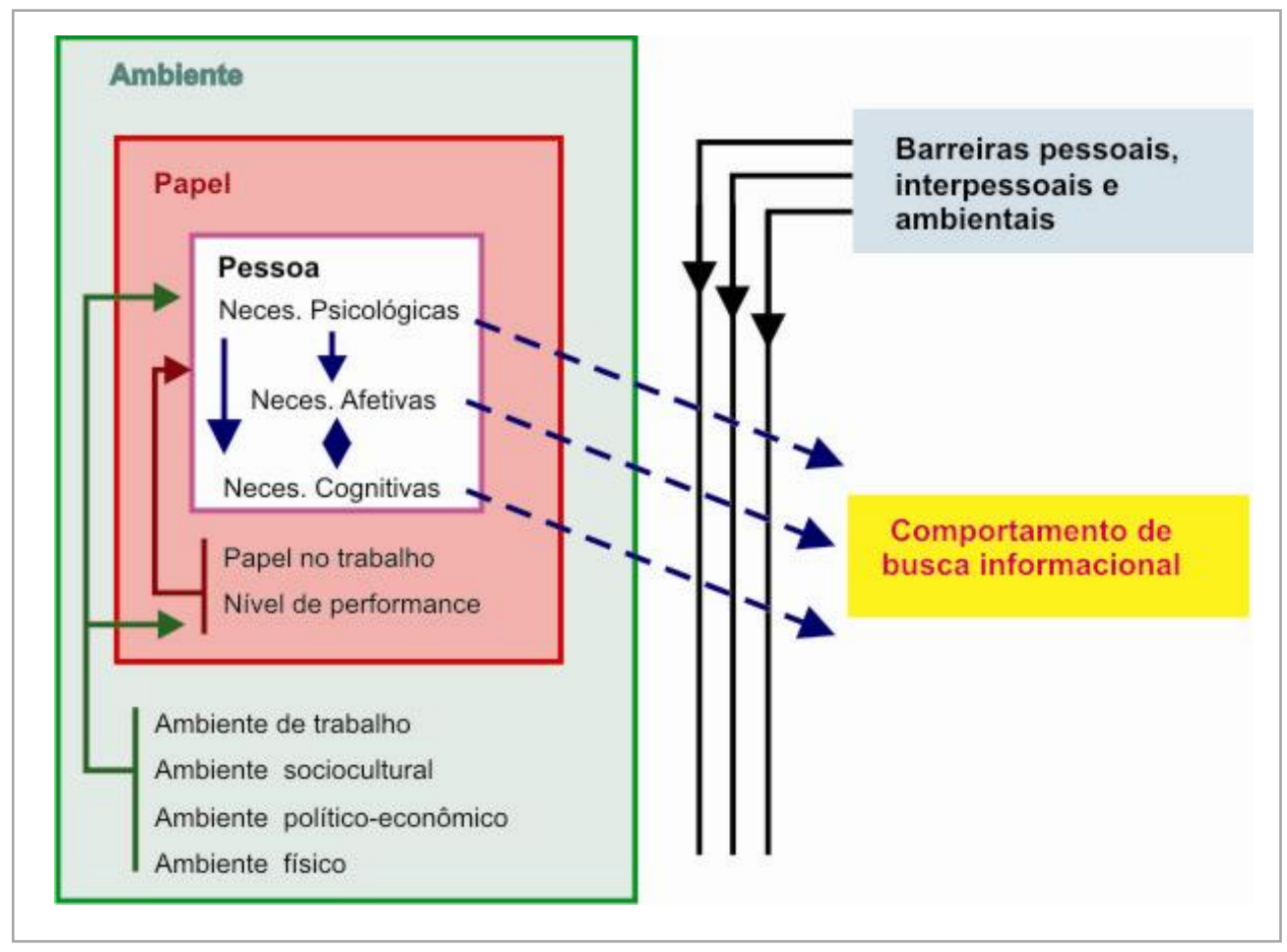

Fonte: Wilson (1981).

De acordo com os conceitos descritos, optou-se por adaptar o modelo de comportamento de busca da informação proposto por Wilson (1981) para atender aos objetivos do estudo. A proposta do autor considera que a informação é necessidade secundária, com origem nos níveis primários de necessidade do indivíduo, tais como comer, beber, dormir. Outro fator considerado é que os indivíduos podem encontrar barreiras ou facilitadores do processo de busca da informação. O autor apresenta a importância da interação do indivíduo com o ambiente da informação na totalidade, evidenciando a ação de influências e potenciais barreiras que podem ser diagnosticadas e trabalhadas para se atingir a eficácia e eficiência do processo de pesquisa da informação qualificada com o objetivo da tomada de decisão. Em modelo desenvolvido posteriormente, Wilson (1999) destaca que o comportamento de busca de informações pode envolver outras pessoas, pela troca ou transmissão de informação, considerando-se que a informação percebida como útil pode ser transmitida para outras pessoas, e não apenas utilizada pela pessoa que a pesquisou, o que evidencia a importância do compartilhamento da informação, aspecto importante em vista da enorme quantidade de informação existente à disposição da sociedade (CHOO, 2006).

O modelo revisitado de comportamento informacional de Wilson (1999) foi utilizado no estudo realizado por Martinez-Silveira e Oddone (2007), com médicos residentes e o interesse sobre a saúde do pacientes. As autoras perceberam que as variáveis que interagem na 
decisão da busca da informação são essencialmente de origem psicológica, em relação à simples curiosidade ou necessidade de conhecer; e demográfica, indivíduos relativamente jovens, estudantes; dentre outras.

Figura 16 - Modelo revisado de comportamento informacional de Wilson.

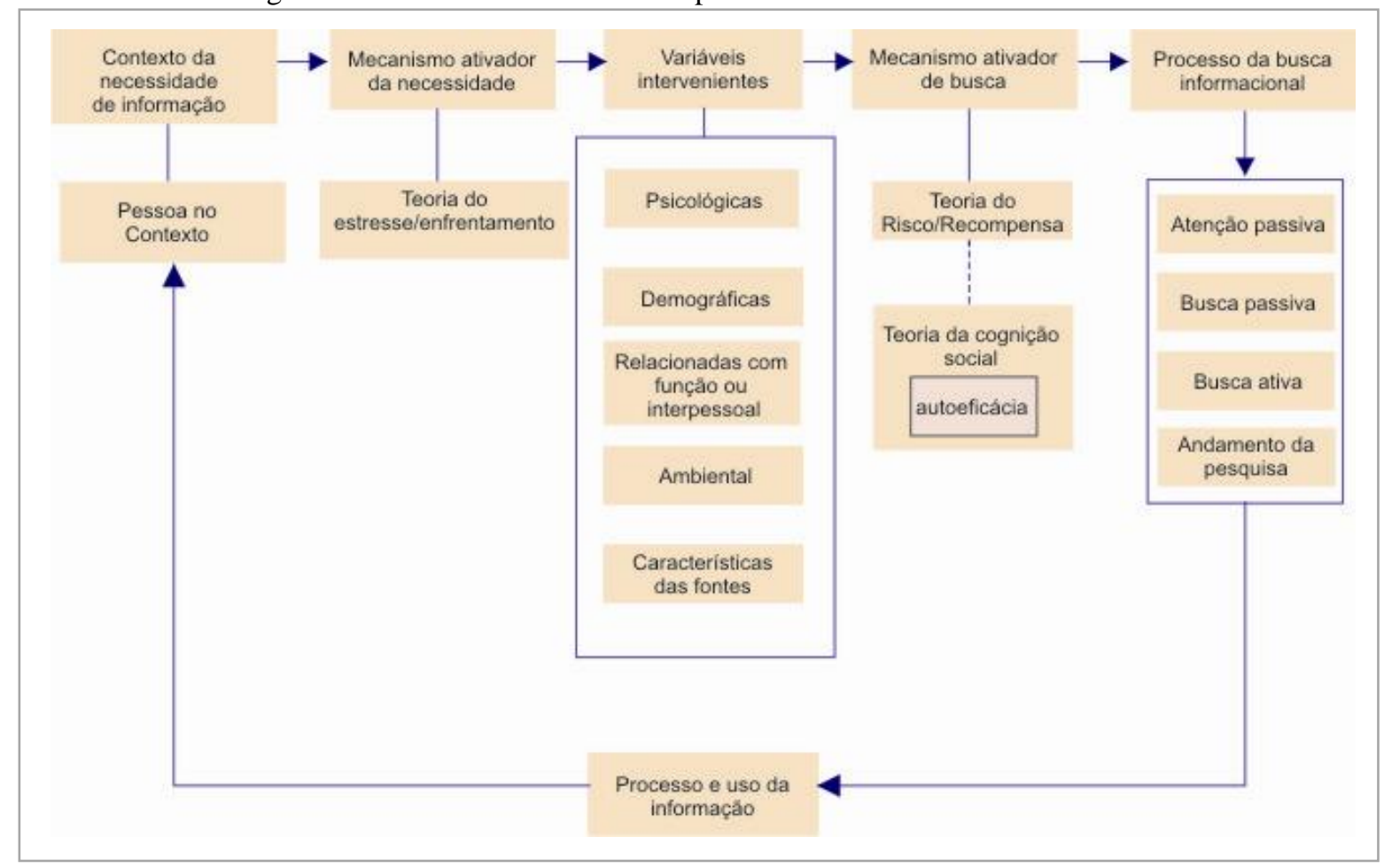

Fonte: Wilson (1999)

Outra aplicação prática do conceito encontra-se em Soares (2002), que investigou o comportamento informacional de gestores de empresas de base tecnológica. Realizou-se pesquisa de usuários que atuam em micro e pequenas empresas de desenvolvimento e comercialização de softwares vinculadas ao Núcleo Tecsoft do Programa Softex ${ }^{16}$. Os resultados mostraram que o comportamento dos gestores é influenciado por características pessoais, pelas atividades que desempenham e também pelo processo de comunicação organizacional, por ser o elo que estabelece a importância e a aplicação dos canais de acesso à informação - conversas pessoais, correio eletrônico e internet. Outro ponto demonstrado pelo trabalho foi o objetivo da busca da informação: o interesse dos usuários sobre a opinião dos clientes quanto aos produtos por eles desenvolvidos, cujas sugestões e críticas refletem

16 O Programa SOFTEX foi criado em 1992 pelo Conselho Nacional de Pesquisa (CNPq ) e Ministério da Ciência e Tecnologia (MCT), com o objetivo de estimular o crescimento da indústria de software no país e tornar o Brasil um dos principais países produtores e exportadores de software (Programa Softex Disponível em: < http://www.softex.br/_asoftex/programaSoftex.asp>. Acesso em 26, Jun. 2013). 
diretamente no desenvolvimento do produto. Ou seja, o retorno do ambiente ocorre pelo fornecimento insumos para a organização, e esta devolve, na forma de inovação no produto ou serviço prestado pela organização. Mais uma vez, encontra-se o emprego do modelo de comportamento de busca da informação aplicado a sistemas, validando o conceito de que o macro - a busca - contém o micro - a pesquisa.

Em artigo recente, Taylor (2012) estudou diversos modelos desenvolvidos ${ }^{17}$ de processo de busca de informações que fornecem estrutura para o estudo e avaliação de pesquisas de informações. Contudo, o autor defende que os modelos antecederam o uso da internet como fonte de informação, acarretando limitações nas aplicações dos modelos. Outras questões foram apontadas, como os atores dos trabalhos que, apesar de considerarem diversas faixas etárias, não incluíram a geração do milênio, como são conhecidos os nascidos no mundo digital, entre os anos de 1982 e 2000, com fontes de informação onipresentes.

Diante deste contexto, o referido estudo propõe adaptação do modelo de Wilson (1981), em que procura-se ilustrar como as variáveis de comportamento informacional dos usuários de portais corporativos devem ser consideradas, no intuito de ampliar a eficácia e eficiência do processo de pesquisa da informação em portais corporativos. Portanto, além da proposta de Wilson(1981), foi incorporada nas análises deste estudo a proposta de Dias (2001b), com as proposições de requisitos mínimos de um portal corporativo.

\subsection{EMERGÊNCIA DO LETRAMENTO INFORMACIONAL}

[...] profissionais de informação devem ter presença assegurada para desempenhar um papel muito mais importante, enquanto produtores de conhecimento, cabendolhes buscar sua estratégia de atuação como agentes sociais, privilegiando, nas suas formações, competências sobre o domínio e a rentabilização de fluxos de informação (SANTOS, 2001, p. 2).

Oriundo dos Estados Unidos, o termo letramento informacional (originalmente cunhado de Information Literacy ${ }^{18}$ ) é empregado para se referir ao processo que associa as atividades de "localizar, selecionar, acessar, organizar, usar informação e gerar conhecimento, visando à tomada de decisão e à resolução de problemas" (GASQUE, 2012, p. 26).

17 Taylor (2012) apresenta considerações a respeito dos modelos de Kuhlthau (1993), Ellis ( 1989 ) e Wilson (1999), referências na área, e reconhece a importância de cada um. Porém, ressalta que foram antecessores ao advento da massificação da internet, portanto não a considera como fonte de informação acessível, bem como a geração que nasceu na época.

18 Information literacy foi a expressão definida pelo bibliotecário Paul Zurkowski para assumir o significado de ferramenta de acesso à informação, proposta apresentada no ano de 1974 em seu relatório The information service environment relationships and priorities. 
Tal e qual o termo comportamento informacional, há diversas nomenclaturas para sua tradução, tais como o Alfabetização Informacional (ALFIN), usado na Espanha; e Literacia da Informação, em Portugal. Conforme Gasque (2012), a expressão apareceu no Brasil no início do Século XXI, ainda em inglês Information Literacy, tendo sido seguida de outras traduzidas: letramento informacional, alfabetização informacional, habilidade informacional e competência informacional. No entanto, a autora reforça a importância desses termos não serem considerados sinônimos, apesar de apresentarem estreita relação entre si - literacia, letramento e alfabetização estão mais próximos, assim como competência e habilidades estão em outro grupo.

Particularmente no Brasil, os termos letramento e alfabetização tem sido confundidos, talvez devido a aproximação semântica. Gasque (2012) considera as diferenças básicas:

a) A alfabetização - relacionada ao domínio básico do código da língua, abrange conhecimentos e habilidades variados (tais como a memorização das letras/sons; palavras e significados; a compreensão do alfabeto; o domínio e a aprendizagem de instrumentos como cadernos e computador);

b) O letramento -envolve mais do que a decodificação informacional, considera o efetivo emprego da informação em um contexto, situação em que a experiência do indivíduo é fator preponderante.

Para Gasque (2012, p. 32), "o letramento informacional abrange a capacidade de buscar e usar a informação eficazmente", ou seja, tem como pré-requisito conhecimento básico das ferramentas, produtos e serviços informacionais, competências 19. Em se tratando dos conteúdos indispensáveis para a busca e uso da informação, o usuário deve saber produzir bons textos, elaborar projetos e implementá-los, bem como comparar dados, para além de conhecer a organização do material de referência, as políticas da organização, normas de formatação de documentos e empregar eficazmente os mecanismos de buscas da internet.

Ainda segundo a autora, a busca e o uso da informação são atividades que compõem o processo de aprendizagem, pois o pensamento é edificado na interação entre novas informações com o conhecimento prévio e experiências vividas, como já demonstrado com a pseudoequação de Brookes (1980) e corroborado por Choo (2006). Gasque (2012, p. 69) ressalta que, "quanto mais experiência as pessoas adquirem com o manejo da informação, maior o impacto no conhecimento produzido". No entanto, ainda são necessárias algumas mudanças

19 O termo competência é definido pelo Aurélio como "qualidade de quem é capaz de apreciar e resolver certo assunto". No âmbito empresarial, assume o propósito de buscar a melhoria da produtividade e a competitividade no trabalho (GASQUE, 2003). 
para se atingir níveis satisfatórios em lidar com a informação. Há enorme esforço dos indivíduos para conseguir buscar a informação em meio eletrônico.

Temos examinado estudos sobre o impacto da leitura eletrônica no aprendizado. Os estudos ainda não são numerosos. Mas, até aqui, têm mostrado - e acho que isso vai mudar com o tempo - que as pessoas extraem mais informação ao ler livros físicos. O olho humano ainda não está treinado para absorver da tela do computador o mesmo tanto que absorve do livro de papel. [...] Por séculos, habituamo-nos à leitura em livros físicos. E só agora, só muito recentemente, nosso cérebro e nosso nervo óptico estão começando a lidar com um ambiente diferente. Leva tempo (SHAFFER, 2012, p. 156).

A questão é que o ambiente de negócios tem pressa na absorção de ideias e geração de inovações. O Conhecimento nas organizações é fruto da atividade das pessoas trabalhando juntas, compartilhando experiências e construindo significados. A transferência de tecnologia demanda processo eficaz de transferência de conhecimentos, tácito e explícito, de um profissional a outro, como meio de inovação e resposta à criação de valor agregado (CHOO, 2006). Para interpretar ou monitorar os ambientes, os gestores precisam ter competência na busca e emprego da informação qualificada. Então, fica o enorme desafio para as organizações: ter profissionais capazes de interpretar adequadamente os ambientes organizacionais de negócios, conhecer o mercado e o consumidor (AMARAL, 2007).

De acordo com Choo (2006), a tomada de decisões demanda capacidades limitadas dos decisores, na seleção de informações, tanto cognitivas quanto de processamento da informação, motivo pelo qual a organização precisa estabelecer regras, premissas e programas de desempenho para reduzir a incerteza e a complexidade, simplificando o processo decisório. O autor sugere o modelo de tomada de decisão em que destaca a importância da organização compreender a criação de significado e realidade, e como a realidade interpretada fornece contexto para a ação organizacional, incluindo a construção de conhecimento e a tomada de decisões com vistas à inovação em processos e produtos. 
Figura 17 - Processo de tomada de decisão na organização.

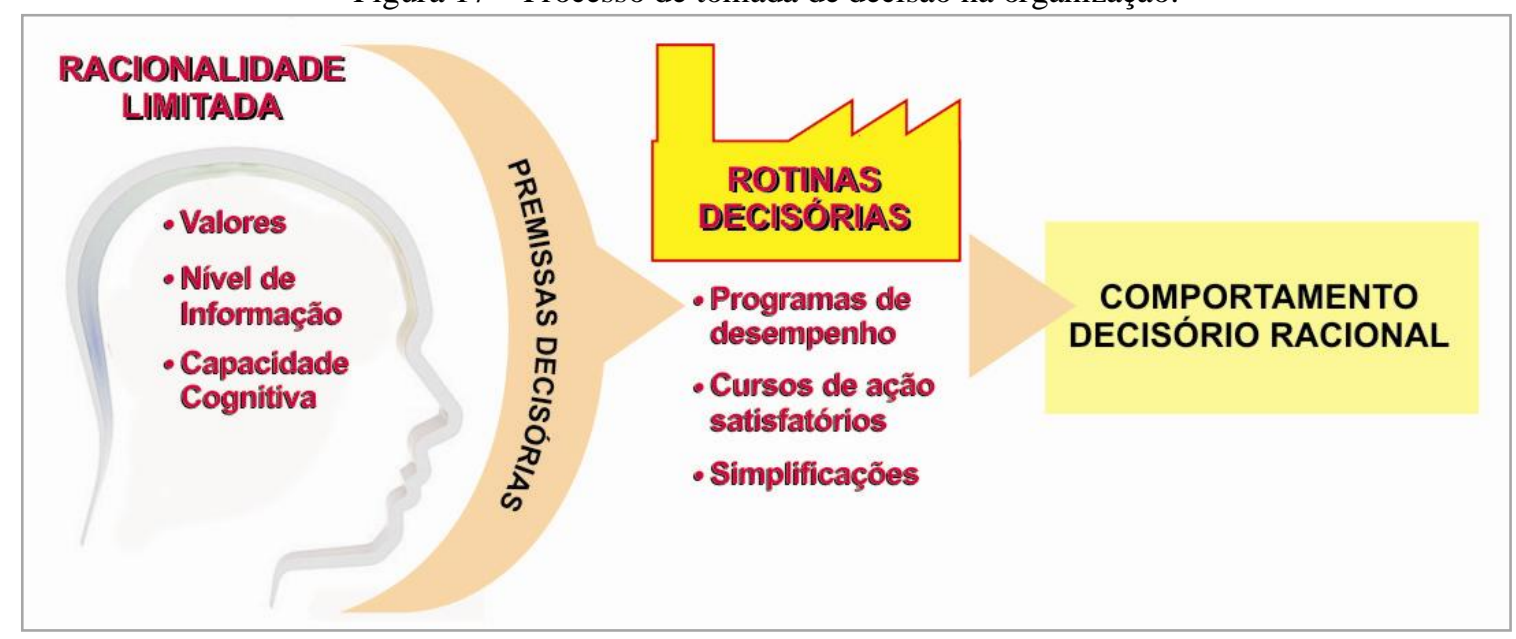

Fonte: adaptado de Choo (2006, p. 44).

Para colaborar com o processo, as organizações utilizam TICs, que propiciam maior velocidade na obtenção de informação qualificada proveniente das infovias e demais alternativas que surgiram com o mundo digital (SOUZA, 2008); abriram novas possibilidades de conectividade em rede, particularmente no chamado ciberespaço, onde acontecem diversas rupturas, de tempo e espaço, de produção e recepção de mensagens que se confundem com os meios e as finalidades. $\mathrm{O}$ autor afirma que as redes vão além de meros meios técnicos de produção, circulação e consumo de informação e se tornam canais de múltiplas inserções nos quais dados são compartilhados e o "mundo simbólico se alimenta", aproveitando-se do deslocamento da dimensão de espaços - físico e cultural, bem como do social e político, em um sentido glocal $^{20}$ (SOUZA, 2008, p. 57).

Conforme César (2008), a comunicação entre os colaboradores da organização tem sido cada vez mais valorizada, considerada área estratégica em virtude de ser considerada o meio para a almejada competitividade, característica essencial para a sobrevivência no ambiente socioeconômico globalizado, cuja reorganização internacional do capital e trabalho levou a cenários mutantes e mercados maduros, formados por consumidores cada vez mais exigentes. Em situação diametralmente oposta, aqueles que não participam deste contexto estão fazendo uma opção pelo midiacídio, quando a ruptura tecnológica acaba com mídias tradicionais incapazes ou que ainda não se adaptaram às mudanças do ambiente midiático em ascensão. A autora defende esta ideia também para as carreiras de profissionais de diversas

${ }^{20}$ O termo glocal refere-se ao planejamento estratégico das organizações de uma economia globalizada que deve considerar a análise do ambiente global, porém pensar em implicações e atuações locais (YANAZE, 2006). 
áreas e para empresas que não perceberem a importância de evoluir, tanto os modelos de negócio quanto as linguagens por eles utilizados. "Portanto, a comunicação digital integrada é um processo dinâmico, em transição contínua e irreversível no ambiente das organizações contemporâneas. A nós cabe compreender e aplicar suas estratégias e ferramentas" (CORRÊA, 2008, p. 175).

Beal (2007) comenta que o cenário atual para a TI tem se mostrado bastante favorável, tendo alçado a posição de área estratégica por agregar qualidade a processos e produtos, gerando valor para o negócio, que ocorreu graças ao aumento da infraestrutura de tecnologia e profissionais, de diversas áreas, com maior conhecimento em equipamentos e programas. As organizações passaram a investir cada vez mais em TI com objetivo de conectar diversos públicos-alvo, inúmeros processos e parceiros, devidamente motivadas pela redução crescente de custos de aquisição e implantação de máquinas e redes, bem como por programas mais amigáveis ${ }^{21}$ para os usuários.

Davenport (2003) considera que o uso da tecnologia proporciona inúmeros benefícios às organizações, quando apropriadamente empregada. $\mathrm{O}$ autor considera essencial que os recursos sejam dimensionados em conformidade com as demandas de complexidade e capacidade da empresa, e que haja grandes investimentos em outros fatores essenciais à incorporação de todo o investimento, como a estrutura organizacional, a cultura e os processos e comportamentos relativos à informação.

Em suma, Gasque e Costa (2010, p. 31-32) demonstram que o comportamento informacional pode ser interpretado também como " processo natural do ser humano no papel de aprendiz da própria vida". As autoras indicam que, apesar de ser natural, o processo de aprendizagem humana para gerenciar e usar as informações pode ser mais eficaz se houver emprego de sistematização e ensino do conhecimento. Ou seja, se os atores do processo forem letrados informacionalmente. Assim, apresentam como um dos muitos desafios dos pesquisadores da ciência da informação a geração de conhecimento "que possa ser utilizado em prol da conscientização, da educação e da construção da cidadania com o uso desse saber, com vistas a um mundo sustentável, ético e viável”. Tais pontos são, na realidade, objetivos almejados pelas organizações que buscam a competitividade na atual economia globalizada.

Diante deste contexto, o letramento informacional destaca-se como recurso essencial para lidar com a informação ao promover a aquisição e desenvolvimento de competências que

21 Amigável, de acordo com o Aurélio, refere-se a "espírito conciliador" em relação à interface com o usuário, que possibilita maior interação com o usuário do programa e/ou equipamento. 
permitem o usuário identificar, acessar, organizar e selecionar a informação para usufruto e geração de conhecimento organizacional (GASQUE, 2012).

\subsection{PORTAL CORPORATIVO}

Implementar e desenvolver a cultura da colaboração ou a cultura da competitividade dependem da criação do contexto e da abordagem da organização em relação ao tipo de prática motivacional que vier a adotar. O indicado, pela literatura, é estimular a cooperação entre a força de trabalho da empresa e não a competitividade. (MORESI; MENDES, 2010, p. 28).

Choo (2006) destaca que a construção e o uso eficaz do conhecimento é um desafio para as empresas, uma vez que conhecimentos e experiências se encontram distribuídos pela organização, porém concentrados em determinados indivíduos (ou unidades de trabalho). Por não serem capazes de localizar o conhecimento desejado, porém pré-existente, as organizações se vêm obrigadas ao retrabalho, comprometendo a competitividade da organização.

Corrêa (2008) apresenta o conceito de espaço-informação: uma proposta de espacialidade associada à construção de conteúdos com determinada lógica, disponibilizados de forma ergonômica, que favoreça a consulta por parte do utilizador ao demandar alguma informação corporativa. Conforme descreve a autora, a ideia é agregar o conteúdo propriamente dito (dados, informações, design, arquitetura e outros); a aplicação da hipermídia (para ofertar ao conteúdo amplitude e profundidade, por exemplo); o uso de recursos de interatividade como convite ao constante diálogo entre empresa e colaborador.

Os portais corporativos têm sido apontados como soluções para atender à demanda por informação qualificada. Representam uma evolução das intranets corporativas (DIAS, 2001b), cujo principal diferencial é a disponibilidade de meios de colaboração que permitem aos funcionários interagir na construção e disseminação do conhecimento organizacional (SALDANHA, 2012). Outra característica importante dos portais corporativos consiste na capacidade de integração de sistemas heterogêneos em uma única aplicação, como proposta de se tornar "a porta de entrada" para os sistemas de informação da organização (DIAS, 2001b). 
O Instituto Gartner ${ }^{22}$ definiu como importante diferencial de portais a visão conceitual conhecida como "Portal, Content \& Collaboration" (Integração, Conteúdo \& Colaboração) em única abordagem, utilizada como parâmetro para o Prêmio Intranet Portal $^{23}$ : o reconhecimento máximo (em âmbito nacional) de empresas brasileiras que desenvolvem soluções em intranets e portais. Esta tríade representa as principais proposições de valor que devem estar contidas em uma intranet ou portal corporativo, que se tornaram critérios de avaliação dos concorrentes ao prêmio e passaram a constituir "elemento de valor" para o mercado organizacional como um todo, "uma vez que sinaliza explicitamente elementos avançados que um portal corporativo pode e deve possuir" (SALDANHA, 2012, p. 12).

Figura 18 - Proposições de valor de um portal corporativo ou intranet.

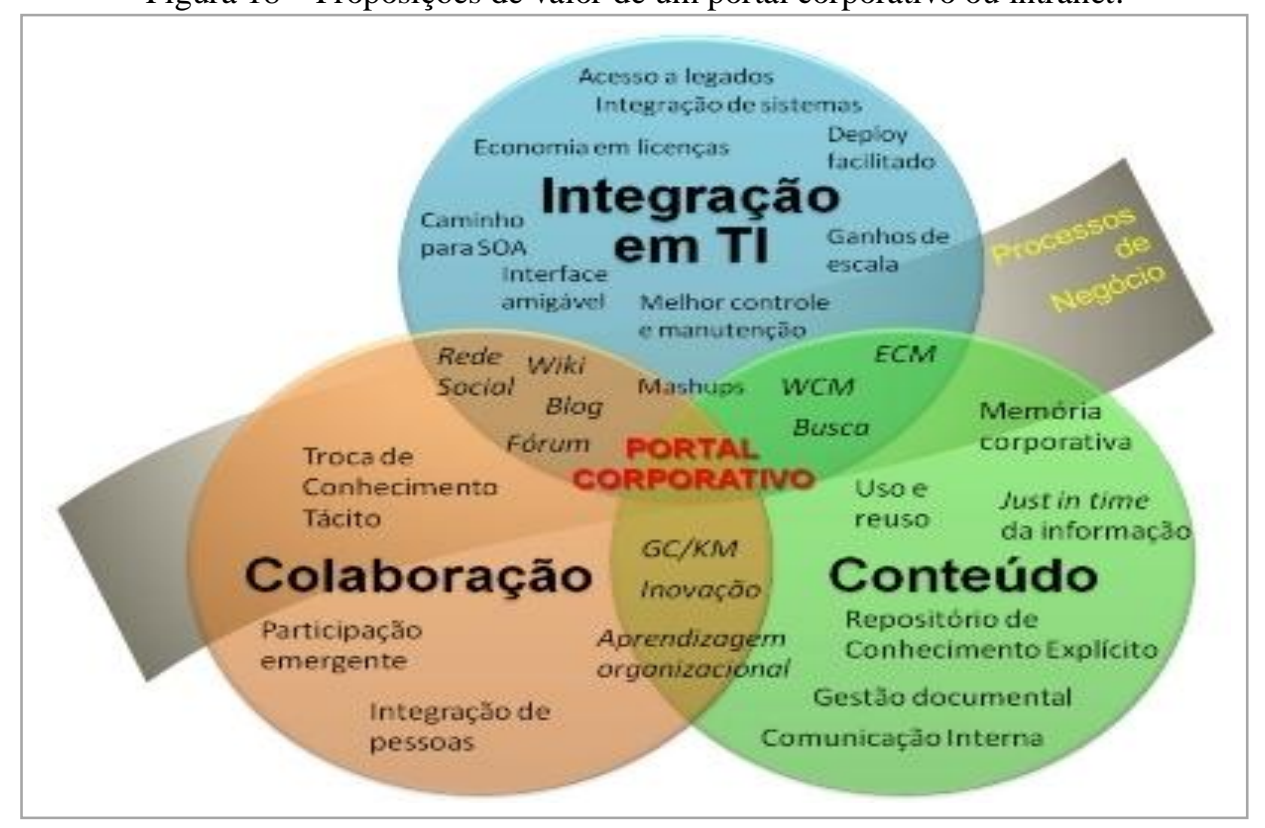

Fonte: SALDANHA (2012, p. 9).

Ratificando esta proposta, Dias (2001b), destaca como características essenciais em um portal corporativo "[...] a capacidade de facilitar o acesso dos usuários às informações institucionais está intrinsecamente relacionada à facilidade de uso, aprendizado e satisfação do usuário com sua interface web". Em outras palavras, promovem a integração e

${ }^{22}$ O Instituto Gartner é reconhecido no campo empresarial como líder mundial em pesquisa e aconselhamento sobre tecnologia.

23 Esta premiação foi instituída em 2008 pelo Instituto Intranet Portals (IIP ), com a proposta de valorizar intranets e portais corporativos como elementos estratégicos para o mundo dos negócios, reconhecendo casos organizacionais que possam inspirar outros. O fato é que a iniciativa causou boa repercussão e já está na $5^{\text {a }}$ edição, pois tem conseguido editar as melhores práticas, promovendo o aprendizado e desenvolvimento do setor. 
comunicação, auxiliando os profissionais a desempenhar suas atividades. Para gestores, os portais corporativos são ferramentas essenciais para o processo de tomada de decisão eficaz, por centralizarem o acesso aos principais recursos informacionais e de conhecimento da organização tais como relatórios, atas, dados financeiros e pesquisas de mercado, por exemplo (MORESI; MENDES, 2010).

Para Dias (2001a), a existência de diferentes tipos de portais se justifica devido ao contexto de utilização (em públicos ou corporativos), e em conformidade com as funções que desempenham (apoio à tomada de decisão ou processamento corporativo). A autora também destaca que a terminologia relacionada aos portais corporativos não está definida, pois se trata de conceito recente no ambientes empresarial. Desta feita, portal de informações corporativas, portal de negócios, portal de informações empresariais são tidos como sinônimos, comumente empregados na literatura especializada e por profissionais da área.

A autora defende o termo portal corporativo para o ambiente de convergência de diversas tecnologias existentes - sistema de inteligência de negócios, gestão de documentos, data warehouse, intranet, dentre outros, o que torna o desenvolvimento de um projeto de portal corporativo uma escolha nada fácil.

Outra dificuldade é encontrar dados, quaisquer índices que possam demonstrar as vantagens de um portal corporativo. A título de ordem de grandeza, pesquisas realizadas em 2001 pela Agency.com e Harris Interactive ${ }^{24}$, indicaram que, na época, profissionais que acessam soluções de portais corporativos economizam cerca de 2,84 horas semanais, o que correspondiam 7,1\% do horário de trabalho, deixando-as livres para focalizarem esforços nas atividades fins para os quais foram contratados (FIGUEIREDO, 2005).

Como prova final do amadurecimento das intranets e portais corporativos no
mercado corporativo brasileiro é que $73 \%$ dos inscritos no Prêmio Intranet Portal
fazem planejamento anual dos seus ambientes. Essa porcentagem é surpreendente,
mesmo se comparada a pesquisas e estudos globais sobre o segmento. Como se sabe
esses ambientes são orgânicos e demandam acompanhamento e planejamento
regulares para que seja mantido o alinhamento ao negócio - único caminho para
quem quer agregar real valor (SALDANHA; VIBERTI, 2011, p. 2).

O Instituto Intranet Portal tem sido referência na área para profissionais e empresários do setor, por ser uma organização sem fins lucrativos criada com intuito de viabilizar análises de mercado e identificar boas práticas das empresas envolvidas, fato que resultou na

24 A Agency.com fundiu-se à Designory, empresa de design norte-americana que possui presença inclusive em Tokyo (http://designory.com/). A Harris Interactive realiza trabalhos na áreas de comunicação e marketing em diversos países, tais como Canadá, Reino Unido, França, etc. (http://www.harrisinteractive.com/). 
implantação do Prêmio Intranet Portal. Atualmente na $5^{\text {a }}$ edição (correspondente ao biênio 2012/2013), casos vencedores integram o livro editado pela instituição para disseminação do conhecimento - parte da missão do instituto - e que tem sido utilizado por profissionais que trabalham na área de desenvolvimento de portais por indicar o estado da arte em portais corporativos, uma vez que apresentam os resultados positivos obtidos pelas corporações na gestão.

Uma referência na área acadêmica tem sido o estudo de Dias (2001b), que baseou-se em propostas anteriores ${ }^{25}$. No quadro abaixo, pode-se verificar 15 requisitos ${ }^{26}$ tais como viabilizar a localização das informações por parte dos usuários, mesmo que eventuais; prover a classificação e a pesquisa intuitiva; disseminar o compartilhamento corporativo; disponibilizar acesso (geral ou restrito) aos recursos informacionais da organização; permitir definições flexíveis das permissões de acesso; segurança, fácil administração, customização e personalização; dentre outros aspectos, conforme detalhados a seguir.

25 A proposta final de sua pesquisa baseou-se em ECKERSON, Wayne. 15 regras para portais corporativos. Revista Oracle, v. 13, n.4, p. 13-14. Jul/Ago, 1999. Disponível em: $<$ http://www.oracle.com/oramag/oracle/99-jul/49ind.html>. Acessado pela autora em abril, 2000, atualmente não disponível.

26 Idem. 
Figura 19 - Requisitos mínimos de um portal corporativo.

\begin{tabular}{|c|c|}
\hline Requisito & Descrição \\
\hline Fácil para usuários eventuais & $\begin{array}{l}\text { Os usuários devem conseguir localizar e acessar facilmente a informação correta, com o mínimo de } \\
\text { treinamento, nâo importando o local de armazenamento dessa informaçấo. Encontrar informaçốes } \\
\text { de negócios no portal deve ser tâo simples quanto usar um navegador web. }\end{array}$ \\
\hline Classificação e pesquisa intuitiva & $\begin{array}{l}\text { Oportal deve ser capaz de indexar e organizar as informaçōes da empresa. Sua máquina de busca deve } \\
\text { refinar e filtrar as informaçōes, suportar palavras-chave e operadores booleanos, e apresentar o } \\
\text { resultado da pesquisa em categorias de fácil compreensão. }\end{array}$ \\
\hline Compartilhamento cooperativo & $\begin{array}{l}\text { O portal deve permitir aos usuários publicar, compartilhar e receber informaçổes de outros usuários. } \\
\text { O portal deve prover um meio de interação entre pessoas e grupos na organização. Na publicação, o } \\
\text { usuário deve poder especificar quais usuários e grupos terão acesso a seus documentos/objetos. }\end{array}$ \\
\hline $\begin{array}{l}\text { Conectividade universal aos } \\
\text { recursos informacionais }\end{array}$ & $\begin{array}{l}\text { O portal deve prover amplo acesso a todo e qualquer recurso informacional, suportando conexão } \\
\text { com sistemas heterogêneos, tais como correio eletrônico, bancos de dados, sistemas de gestão de } \\
\text { documentos, servidores web, groupwares, sistemas de áudio, vídeo etc. Para isso, deve ser capaz de } \\
\text { gerenciar vários formatos de dados estruturados e não estruturados. }\end{array}$ \\
\hline $\begin{array}{l}\text { Acesso dinâmico aos recursos } \\
\text { informacionais }\end{array}$ & $\begin{array}{l}\text { Por meio de sistemas inteligentes, o portal deve permitir o acesso dinâmico às informaçōes nele } \\
\text { armazenadas, fazendo com que os usuários sempre recebam informaçōes atualizadas. }\end{array}$ \\
\hline Roteamento inteligente & $\begin{array}{l}\text { O portal deve ser capaz de direcionar automaticamente relatórios e documentos a usuários selecio- } \\
\text { nados. }\end{array}$ \\
\hline $\begin{array}{l}\text { Ferramenta de inteligência de } \\
\text { negócios integrada }\end{array}$ & $\begin{array}{l}\text { Para atender às necessidades de informação dos usuários, o portal deve integrar os aspectos de } \\
\text { pesquisa, relatório e análise dos sistemas de inteligência de negócios. }\end{array}$ \\
\hline Arquitetura baseada em servidor & $\begin{array}{l}\text { Para suportar um grande número de usuários e grandes vol umes de informaçōes, serviços e sessōes } \\
\text { concorrentes, o portal deve basear-se em uma arquitetura cliente-servidor. }\end{array}$ \\
\hline Serviços distribuídos & $\begin{array}{l}\text { Para um melhor balanceamento da carga de processamento, o portal deve distribuir os serviços por } \\
\text { vários computadores ou servidores. }\end{array}$ \\
\hline $\begin{array}{l}\text { Definição flexível das permissōes de } \\
\text { acesso }\end{array}$ & $\begin{array}{l}\text { O administrador do portal deve ser capaz de definir permissōes de acesso para usuários e grupos da } \\
\text { empresa, por meio dos perfis de usuário. }\end{array}$ \\
\hline Interfaces externas & O portal deve ser capaz de se comunicar com outros aplicativose sistemas. \\
\hline Interfaces programáveis & $\begin{array}{l}\text { O portal também deve ser capaz de ser "chamado" por outros aplicativos, tornando pública sua } \\
\text { interface programável (API - Application-Programming Interface). }\end{array}$ \\
\hline Segurança & $\begin{array}{l}\text { Para salvaguardar as informaçōes corporativas e prevenir acessos não autorizados, o portal deve } \\
\text { suportar serviços de segurança, como criptografia }{ }^{10} \text {, autenticaçãoo }{ }^{11} \text {, firewalls }{ }^{12} \text { etc. Deve também } \\
\text { possibilitar auditoria dos acessos a informaçōes, das alteraçōes de configuraçãoetc. }\end{array}$ \\
\hline Fácil administração & $\begin{array}{l}\text { O portal deve prover um meio de gerenciar todas as informaçōes corporativas e monitorar o funci- } \\
\text { onamento do portal de forma centralizada e dinâmica. Deve ser de fácil instalação, configuração e } \\
\text { manutenção, e aproveitar, na medida do possível, a base instalada de hardware e software adquirida/ } \\
\text { contratada anteriormente pela organização. }\end{array}$ \\
\hline Customização e personalização & $\begin{array}{l}\text { O administrador do portal deve ser capaz de customizá-lo de acordo com as políticas e expectativas } \\
\text { da organização, assim como os próprios usuários devem ser capazes de personalizar sua interface para } \\
\text { facilitar e agilizar o acesso às informaçôes consideradas relevantes. }\end{array}$ \\
\hline
\end{tabular}

Fonte: Dias (2001b, p. 57).

Além destes requisitos, a autora propôs o acréscimo de outras necessidades como essenciais para um portal corporativo: viabilizar o gerenciamento do ciclo de vida das informações; possibilitar a localização de profissionais na empresa que sejam especialistas em áreas específicas de determinados projetos; possuir a capacidade de satisfazer as necessidades de informação dos usuários da organização e, ainda, permitir a troca de informações com os stakeholders.

Percebe-se que o portal corporativo é um recurso importante para ampliar de modo significativo a acessibilidade, disponibilidade e compartilhamento da informação em organizações que buscam a competitividade, e tem se mostrado eficaz na transformação da 
aprendizagem individual em aprendizagem coletiva por incorporar o conhecimento de cada membro participante da organização às práticas organizacionais atuais e tornarem-se colaboradores das práticas futuras, viabilizando o gerenciamento do conhecimento organizacional (DIAS, 2001b). Todavia, são os usuários que promovem o armazenamento, busca, uso e compartilhamento de informações os responsáveis pelo emprego eficaz e eficiente desta ferramenta.

Moresi e Mendes (2010) destacam que ferramentas são importantes no processo de compartilhamento, mas são ineficazes se não existirem pessoas capacitadas para utilizá-las; para incentivar outros (colaboradores e parceiros) a compartilharem o ambiente, disseminarem conhecimento e com isso, gerarem resultados pela inovação de produtos e processos; e novamente serem reconhecidos pelo empenho e dedicação em programas formais de reconhecimento como recompensa pelas contribuições às melhores ideias. 
[...] A escolha da metodologia para uma determinada pesquisa deve estar amparada, em primeiro lugar, na pergunta da pesquisa, pois o objeto de estudo contido na pergunta é o que determina a escolha. [...] Muitas vezes, a natureza da pergunta exige a escolha de mais do que uma única metodologia (BRAGA, 2007, p. 34).

Este capítulo disserta sobre os procedimentos metodológicos empregados na realização do estudo, definidos pelo questionamento inicial e norteados pelo referencial teórico desenvolvido. Contempla também o processo da escolha e coleta de dados investigados, que abrangem o universo e a amostra considerados, bem como meios utilizados para análise dos dados e definição dos resultados da pesquisa.

Este estudo foi precedido do questionamento sobre os profissionais de diversas áreas do conhecimento que têm necessidade de informação qualificada para o emprego eficaz da informação para a tomada de decisões. A questão abrange a grande oferta de informação e a contribuição do portal corporativo como ferramenta facilitadora na seleção de informação qualificada. Portanto, pretende-se investigar o comportamento de pesquisa da informação dos usuários de Portais Corporativos com vistas à tomada de decisão.

A natureza da questão trabalhada requer investigações feitas com triangulação de metodologias, a fim de melhor entender a complexidade do fenômeno e objeto estudados (GOLDENBERG, 2007). Para tanto, utilizou-se abordagens qualitativas e quantitativas na coleta e análise dos dados, de forma a trabalhar valores, representações, hábitos e opiniões, amparados por dados estatísticos que possibilitem complementação necessária para avaliar a complexidade dos fenômenos e fatos específicos da amostra (BRAGA, 2007).

A abordagem quantitativa proporciona meios para que uma população seja passível de comparação, fornecendo dados generalizáveis. Por outro lado, a pesquisa qualitativa permite a identificação de conceitos e variáveis situacionais importantes, que podem ser analisadas em profundidade (GOLDENBERG, 2007).

Apresenta-se a seguir, o detalhamento da metodologia empregada no desenvolvimento do estudo, que permite a identificação de conceitos e variáveis situacionais importantes, bem como o aprofundamento das relações observadas no fenômeno estudado.

\subsection{O MÉTODO}


A proposta do estudo é contextualizar parte dos conceitos sobre a importância do Comportamento Informacional, especificamente pesquisa da informação, por meio de estudo de caso, realizado em uma empresa brasileira do setor elétrico, a Eletrobras Eletronorte, na qual foi desenvolvido um Portal de Conhecimento Corporativo para a criação, disseminação e compartilhamento de conhecimentos nas diversas unidades da empresa. De acordo com Calazans (2007), a unidade de análise de um estudo de caso pode ser individual, um evento, uma organização ou área organizacional, sendo que a seleção desta unidade deve estar associada ao problema da pesquisa.

Apesar de criticados por alguns pesquisadores, por inferirem que as conclusões obtidas de tais estudos nem sempre podem ser aplicadas aos demais, Calazans (2007) afirma que o Estudo de Caso é considerado uma estratégia de pesquisa apropriada à investigação de um fenômeno social complexo. A abordagem propicia analisar fenômenos contemporâneos ocorridos em contextos reais, por isso tem sido muito utilizada nas Ciências Sociais. Ainda de acordo com a autora, não há consenso em relação a classificação do Estudo de Caso, pois alguns pesquisadores consideram-no como estratégia, outros como método de pesquisa e até abordagem de pesquisa ${ }^{27}$.

Para Goldenberg (2007, p. 33), o estudo de caso tornou-se uma das principais modalidades de pesquisa qualitativa em ciências sociais por proporcionar "uma análise holística, a mais completa possível, que considera a unidade social estudada como um todo, seja indivíduo, uma família, uma instituição ou uma comunidade, com o objetivo de compreendê-los em seus próprios termos”.

\subsection{O DESENHO DA PESQUISA}

O desenvolvimento do projeto de pesquisa foi baseado na proposta de Calazans (2007) para estratégia de estudo de caso, conforme detalhado a seguir.

27 Segundo Calazans (2007, p. 40), Estudo de Caso é considerado uma estratégia para Yin (2001), Martins (2006) e Hartley (2004); um método de pesquisa para César (2003) e uma abordagem de pesquisa para Rowley (2004). 
Figura 20 - Estratégia de estudo de caso.

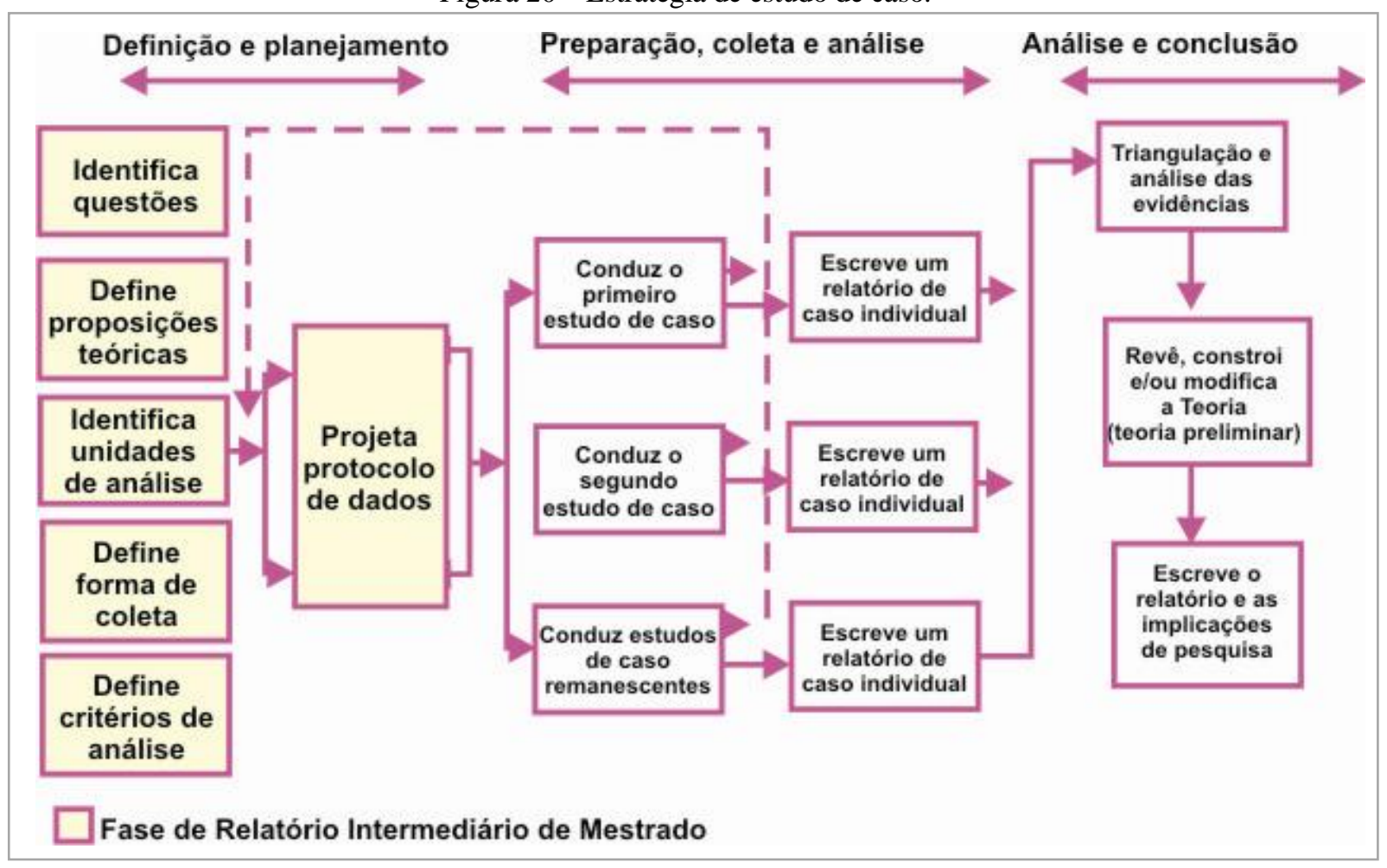

Fonte: adaptado de Calazans (2007, p. 47) .

a) Identificação de questões - na fase preparatória foram realizadas pesquisas exploratórias com intuito de selecionar e conhecer melhor o objeto de pesquisa; identificar a pertinência ao contexto científico e aos padrões do Programa de Pósgraduação em Ciência da Informação (PPGCInf) e, por conseguinte, a formulação do problema da pesquisa. Realizaram-se levantamentos sobre temas e questões abordados no estudo; bem como a seleção da unidade de análise, qual seja, o Portal do Conhecimento Eletrobras Eletronorte, definida por critérios de representatividade e importância da ferramenta no processo de transmissão de informações na área de atuação;

b) Definição de proposições - para complementar as informações e colaborar na delimitação dos objetivos trabalhados, realizou-se entrevista semiestruturada com a equipe de gestores da área que administra o portal do conhecimento, com objetivo de identificar percepções preliminares sobre os usuários do portal; obter prévio levantamento dos acessos e das tecnologias empregadas no portal do conhecimento da Eletrobras Eletronorte; 
c) Identificação das unidades de análise e formas de coleta - as etapas anteriores foram essenciais para compreensão do lócus e determinação das técnicas de pesquisa. Para tanto, empregou-se diversas formas, tais como pesquisa documental, entrevista semiestruturada e questionário, que permitem obter múltiplas origens de evidências e ampliação da base de dados do estudo em questão;

d) Definição de critérios de análise - foram identificadas as principais variáveis trabalhadas no projeto, quais sejam:

- Acesso - a facilidade e obstáculos para o acesso à informação;

- Competência - capacidade e habilidade para pesquisar, empregar e transmitir a informação;

- Pertinência - importância do atendimento à demanda (aplicação) da informação pesquisada.

Partes dos critérios foram preparados com informações provenientes de

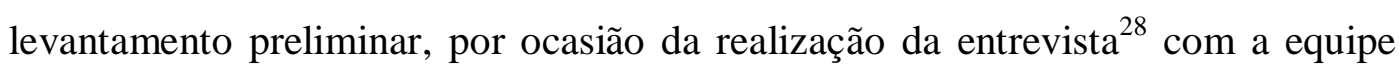
gestora da área, a Assessoria de Educação e Conhecimento (GAE). Na ocasião, foram levantadas informações sobre:

- Percepção dos gestores quanto ao acesso e uso do Portal do Conhecimento;

- Identificação dos conteúdos apresentados no portal;

- Identificação do processo de gestão e monitoramento do portal;

- Acesso aos usuários e composição da amostra: usuários do Portal do Conhecimento situados na sede da organização, em Brasília-DF.

e) Protocolo de coleta de dados - refere-se ao instrumento orientador da estratégia de pesquisa, em que são registrados os passos realizados pelo pesquisador, quais sejam: questões levantadas e potenciais fontes, instrumentos utilizados, tipos de documentos analisados, roteiro de entrevistas, planilhas de coletas de dados, dentre outros. Os documentos integram a seção de anexos;

f) Etapa de preparação, coleta e análise - refere-se ao processo em que o pesquisador deve seguir os parâmetros formais, com objetivo de preservar o controle de qualidade, evitando interferências e conclusões antecipadas;

28 O roteiro da entrevista, bem como a compilação das respostas, transcritas da gravação da reunião, estão disponibilizadas na seção dos anexos do trabalho. 
g) Etapa de análise e conclusão - refere-se à apresentação dos dados devidamente categorizados e informações que, combinada com as teorias preliminarmente identificadas, resultam na explicação do fenômeno ou questão levantada no início do processo.

\subsection{POPULAÇÃO E AMOSTRA}

O universo ou população da pesquisa é a totalidade de elementos que possuem características específicas que atendam a um estudo. Geralmente, pesquisadores se utilizam de amostras - um grupo de elementos representativos da população - para desenvolver os trabalhos, uma vez que nem sempre é possível obter informação de todos os elementos que fazem parte do universo estudado. A representatividade da amostra está relacionada diretamente com o processo adotado de seleção dos elementos que a constituem, particularmente com a proporção dos selecionados em relação ao universo (BARROS e LEHFELD, 2000).

A população da pesquisa constitui-se de gestores e usuários do Portal do Conhecimento Eletrobras Eletronorte. Para efeitos de determinação da amostra, considerou-se a média aritmética do número de acessos ocorridos no período entre os meses de outubro/2010 (por volta de 42.000 acessos, por ocasião do levantamento de dados iniciais) e o final do mês de junho/2013 (época de desenvolvimento do pré-teste, quando o contador mensurou 53.900 acessos, aproximadamente). Chegou-se ao valor médio de 370 acessos mensais, o que corresponde a aproximadamente $10 \%$ do número de funcionários administrativos e técnicos que trabalham na organização. Nos primeiros levantamentos, existiam 3.770 funcionários só na Eletronorte, ou seja, sem contar com parceiros e integrantes de projetos das parcerias público-privadas. Desta forma, foi estabelecida a meta de 30 respondentes - correspondentes a quase $10 \%$ da média de acessos mensais - e que, para tal, o instrumento estaria disponível para preenchimento online por um período de duas semanas (09 a 23/08/2013), ou o que fosse atingido primeiro. 
Quadro 3 - Número de empregados(as) por categoria funcional.

\begin{tabular}{|c|c|c|c|}
\hline Descrição & 2010 & 2011 & 2012 \\
\hline \multicolumn{4}{|c|}{ Número de empregados(as) por funçāo gerencial } \\
\hline Feminino & 42 & 50 & 48 \\
\hline Masculino & 212 & 204 & 200 \\
\hline \multicolumn{4}{|l|}{ Número de empregados(as) por cargos } \\
\hline Cargos com nível superior - feminino & 323 & 281 & 271 \\
\hline Cargos com nível superior - masculino & 1.063 & 886 & 864 \\
\hline Cargos sem nivel superior - feminino & 441 & 417 & 418 \\
\hline Cargos sem nivel superior - masculino & 2.030 & 1.975 & 1.956 \\
\hline \multicolumn{4}{|l|}{ Número de diretores } \\
\hline Feminino & 0 & 0 & 0 \\
\hline Masculino & 5 & 5 & 5 \\
\hline
\end{tabular}

Fonte: Eletrobras Eletronorte - Relatório de Sustentabilidade 2012.

Quadro 4 - Composição do corpo funcional.

\begin{tabular}{|c|c|c|}
\hline \multicolumn{3}{|c|}{2.3 - Composição do corpo funcional } \\
\hline $\mathrm{N}^{2}$ de admissōes & 13 & 16 \\
\hline N2 de demissōes & 71 & 53 \\
\hline $\begin{array}{l}\text { N22 de estagiários no final do } \\
\text { exercício }\end{array}$ & 541 & 522 \\
\hline $\begin{array}{l}\text { N2 de empregados portadores de } \\
\text { necessidade especiais no final do } \\
\text { exercício }\end{array}$ & 30 & 31 \\
\hline $\begin{array}{l}\text { N2 de prestadores de serviços } \\
\text { terceirizados no final do exercício }\end{array}$ & 471 & 507 \\
\hline \multicolumn{3}{|l|}{ N2 de empregados por sexo: } \\
\hline - Masculino & 3.020 & 3.067 \\
\hline - Feminino & 737 & 748 \\
\hline \multicolumn{3}{|l|}{ № de empregados por faixa etária: } \\
\hline - Menores de 18 anos & 0 & 0 \\
\hline - De 18 a 35 anos & 791 & 872 \\
\hline - De 36 a 60 anos & 2.620 & 2.667 \\
\hline - Acima de 60 anos & 346 & 276 \\
\hline \multicolumn{3}{|l|}{$\begin{array}{l}\text { N2 de empregados por nivel de } \\
\text { escolaridade: }\end{array}$} \\
\hline - Analfabetos & 0 & 0 \\
\hline - Com ensino fundamental & 346 & 364 \\
\hline - Com ensino médio & 405 & 392 \\
\hline - Com ensino técnico & 1.129 & 1.186 \\
\hline - Com ensino superior & 1.506 & 1.526 \\
\hline - Pós-graduados & 371 & 347 \\
\hline \multicolumn{3}{|l|}{$\begin{array}{l}\text { Percentual de ocupantes de cargos } \\
\text { de chefia, por sexo: }\end{array}$} \\
\hline - Masculino & $81,00 \%$ & $80,00 \%$ \\
\hline - Feminino & $19,00 \%$ & $20,00 \%$ \\
\hline
\end{tabular}

Fonte: Eletrobras Eletronorte - Relatório de Sustentabilidade 2012.

A amostra foi determinada por limitação de tempo e recursos - humanos e financeiros - portanto, decidiu-se, após sugestão da equipe gestora do portal, considerar apenas os funcionários da sede, em Brasília-DF. A sede conta com 1.726 pessoas, dos quais 1.524 são empregados do quadro e 202 empregados terceirizados. Contudo, não foi possível obter dados 
setorizados do acesso, visto que a organização possui o registro de $\mathrm{IP}^{29}$ único, o que faz com que o sistema "leia" apenas um usuário no acesso aos dados. A título de divulgação do estudo e incentivo à participação foi encaminhado convite aos usuários do portal cadastrados na sede da organização, por mensagem de correio eletrônico assinado pela gestora da área (GAE) na forma de Informativo. Além destes esforços, disponibilizou-se banner no Portal do Conhecimento Eletrobras Eletronorte com convite à participação na pesquisa, por ser este o ambiente selecionado para o estudo. Esta unidade de análise deve proporcionar a comparação e o estabelecimento de algum grau de generalização, tornando viável o trabalho de investigação. A proposta é particularmente adequada em virtude das questões de acesso e tempo para coleta dos dados (CALAZANS, 2007).

\subsection{INSTRUMENTOS DE COLETA DE DADOS}

Parte das vantagens do estudo de caso é a possibilidade de coletar as evidências de diversas formas e técnicas, dentre elas entrevista, questionário e pesquisa documental, empregadas neste estudo (CALAZANS, 2007). A seleção dos instrumentos atendeu a critérios de relações com os objetivos propostos:

Quadro 5 - Seleção dos instrumentos de coleta de dados de acordo com os objetivos.

\begin{tabular}{|c|c|}
\hline Objetivos específicos do estudo & Técnica/instrumento de coleta de dados \\
\hline $\begin{array}{l}\text { 1. Levantar dados gerais sobre a empresa e o objeto } \\
\text { de pesquisa. }\end{array}$ & Pesquisa documental; entrevistas com gestores. \\
\hline $\begin{array}{l}\text { 2. Descrever os serviços disponibilizados e os } \\
\text { recursos informacionais do Portal do } \\
\text { Conhecimento Eletrobras Eletronorte; }\end{array}$ & Pesquisa documental; entrevista com gestores. \\
\hline $\begin{array}{l}\text { 3. Identificar o perfil (dados demográficos) dos } \\
\text { usuários do Portal do Conhecimento Eletrobras } \\
\text { Eletronorte; }\end{array}$ & Questionário online \\
\hline $\begin{array}{l}\text { 4. Mapear os padrões de comportamento de } \\
\text { pesquisa da informação dos usuários do Portal do } \\
\text { Conhecimento Eletrobras Eletronorte. }\end{array}$ & Entrevista com gestores e questionário online \\
\hline
\end{tabular}

Fonte: elaboração própria.

29 Do inglês Internet Protocol, também chamado de endereço IP, é a identificação de dispositivo eletrônico (computador, impressora, etc.) que viabiliza o acesso a redes de computadores, local e/ou pública. Cada computador na internet, por exemplo, possui um IP único, espécie de endereço para ser localizado na World Wide Web, comunicando-se com outros computadores. Wikipedia, Disponível em: <https://pt.wikipedia.org/wiki/Endere\%C3\%A7o_IP>. Acesso em 27 abr. 2013. 
Quadro 6 - Finalidades dos instrumentos de coletas de dados utilizados no estudo.

\begin{tabular}{|c|c|c|}
\hline Instrumento & Período & Usado para... \\
\hline $\begin{array}{l}\text { Análise } \\
\text { documental }\end{array}$ & $\begin{array}{l}\text { Pré-projeto, fase } \\
\text { preparatória e de } \\
\text { desenvolvimento } \\
\text { do projeto de } \\
\text { pesquisa }\end{array}$ & $\begin{array}{l}\text { - Selecionar e conhecer melhor o objeto de pesquisa; } \\
\text { - Identificar pertinência ao contexto científico/padrões do PPGCInf; } \\
\text { - Colaborar na formulação do problema da pesquisa. } \\
\text { - Levantar dados sobre os temas e questões abordados no estudo; } \\
\text { - Justificar a seleção da unidade de análise, o Portal do } \\
\text { Conhecimento Eletrobras Eletronorte } \\
\text { - Auxiliar na definição da população e da composição da amostra } \\
\text { para o estudo. }\end{array}$ \\
\hline $\begin{array}{l}\text { Entrevista } \\
\text { semiestruturada }\end{array}$ & $\begin{array}{c}\text { Fase de } \\
\text { desenvolvimento } \\
\text { do projeto de } \\
\text { pesquisa }\end{array}$ & $\begin{array}{l}\text { - Conhecer melhor o objeto de pesquisa; } \\
\text { - Complementar informações coletadas previamente e colaborar na } \\
\text { determinação dos objetivos a serem trabalhados; } \\
\text { - Identificar representatividade e importância do portal no processo } \\
\text { de transmissão de informações na área de atuação. } \\
\text { - Fornecer percepções preliminares sobre os usuários do portal. }\end{array}$ \\
\hline $\begin{array}{l}\text { Questionário } \\
\text { online no portal }\end{array}$ & $\begin{array}{l}\text { Desenvolvimento } \\
\text { da pesquisa }\end{array}$ & $\begin{array}{l}\text { - Coletar percepções dos usuários do portal: acessos; conhecimento } \\
\text { de tecnologias para pesquisa; atendimento das necessidades. }\end{array}$ \\
\hline
\end{tabular}

Fonte: elaboração própria.

\subsubsection{Pesquisa documental}

No início do estudo foram realizadas coletas de dados por meio da análise documental e de entrevista semiestruturada para conhecer melhor o objeto de pesquisa e os elementos pertinentes ao contexto a ser trabalhado, bem como a viabilidade para o desenvolvimento de pesquisa científica.

De acordo com Severino (2007), a pesquisa documental abrange a análise de documentos no sentido geral, impressos e eletrônicos, tais como jornais, gravações, documentos legais, blogs e sítios, em que os conteúdos não tiveram tratamento analítico. $\mathrm{Na}$ pesquisa, foram analisados conteúdos disponibilizados no sítio da Eletrobras, no Portal do Conhecimento Eletrobras Eletronorte, quais sejam: relatórios anuais, jornal interno, documentos sobre gestão e desenvolvimento de diversos projetos nas áreas de inovação e competitividade. Alguns dados quantificados são provenientes do programa gerenciador de biblioteca - SophiA, tais como estatísticas de acesso ao portal conforme período; 
tópicos/assuntos mais acessados/pesquisados; dentre outros, que serviram para definir a população pesquisada e a composição da amostra para o estudo.

\subsubsection{Entrevista com gestores}

A primeira reunião com gestores do Portal do Conhecimento foi realizada em agosto de 2012, com três profissionais, na sede GESEC, então setor responsável pelo portal, em Brasília-DF. O roteiro da entrevista constituiu-se de 10 questões básicas, cujas respostas foram gravadas em áudio e, posteriormente, compiladas e transcritas em documento elaborado no Word (Apêndice A). Em um segundo encontro, em agosto/2013, a gestão do portal já estava sob responsabilidade da Assessoria de Educação e Conhecimento (GAE), área que agrupou a GESEC com a UCEL. Os principais pontos tratados na reunião também foram captados em áudio e transcritos em documento elaborado no Word (Apêndice B).

Segundo Barros e Lehfeld (2000, p. 91), entrevista é uma "técnica que permite o relacionamento estreito entre entrevistado e entrevistador". Dentre as vantagens os autores destacam maior flexibilidade para o pesquisador por possibilitar a reformulação das perguntas para obter melhor compreensão do entrevistado; a observação direta do entrevistador, viabilizando análises de atitudes e reações do entrevistado durante os questionamentos; e a obtenção de dados relevantes do objeto de estudo.

\subsubsection{Questionário}

Para captar percepções sobre os usuários do portal foi utilizado questionário estruturado, autoaplicado, com perguntas abertas e fechadas. Conforme Tomanik (2004), questionário é uma das diversas técnicas que o pesquisador pode utilizar para coleta de dados. Para Goldenberg (2007), questionários podem ser estruturados de formas diferenciadas para atender à demanda do pesquisador: podem ser padronizados e compostos de perguntas abertas e fechadas, conduzindo a resposta para tópicos abordados; ou assistemáticos, quando provêm respostas espontâneas que, apesar de análise mais difícil, remete à liberdade de escolha e pode apontar soluções e caminhos não definidos previamente.

Algumas vantagens apontadas por Goldenberg (2007) para utilização do questionário como coleta de dados serviram para escolha do instrumento: é menos dispendioso; pode ser preenchido remotamente e possibilita aplicação a um grande número de respondentes, ou seja, não necessita da presença do pesquisador, fato que pode conferir menor intimidação e maior 
comprometimento por parte do pesquisado; e por fim, a padronização facilita a mensuração dos dados. Como principais desvantagens indicadas pela autora, foram consideradas a possibilidade de baixo índice de respostas; a padronização da estrutura que pode oferecer rigidez nas respostas e impedir a expressão de sentimentos; a exigência de habilidades de leitura e compreensão de textos, além da disponibilidade para responder às questões.

Parte destas desvantagens são desconstruídas com o emprego de outras técnicas, como entrevista e pesquisa documental. Para a coleta de dados, especial atenção foi dada quanto à forma de abordagem do sujeito (que passou a ser indireta, com o instrumento disponibilizado online), no intuito de se evitar possíveis distorções advindas da interação com o pesquisador, fato que pode comprometer a apuração dos dados. Também houve cuidado na elaboração do instrumento, particularmente quanto à linguagem, clareza e objetividade para não gerar constrangimentos ou interpretações diferenciadas. O questionário elaborado para a pesquisa foi desenvolvido em cinco partes, relacionadas aos objetivos:

a) Parte 1 - visa avaliar o acesso do usuário. Compreende as questões de 1.1 a 1.13;

b) Parte 2 - busca identificar a competência técnica dos usuários para realizar pesquisa da informação. Abrange as questões 2.1 a 2.3;

c) Parte 3 - aborda a utilidade da informação para a tomada de decisão e o compartilhamento da informação. Compõe-se das questões 3.1 a 3.8;

d) Parte 4 - objetiva conhecer a opinião do usuário sobre o processo de pesquisa e natureza da utilização das informações obtidas a partir do Portal do Conhecimento Eletrobras Eletronorte. É composta de apenas uma questão aberta (item 4);

e) Parte 5 - identifica o perfil do respondente, com anonimato garantido pois são solicitados apenas alguns dados para o perfil geral de usuário. Compreende as questões 5.1 a 5.6 do questionário.

Calazans (2007, p. 43) aponta estudos de autores ${ }^{30}$ que propõem a utilização de formatos virtuais para coleta de informações na estratégia do estudo de caso, tais como programas de bate-papo (chats), algo que a autora batizou de "terceira geração desta estratégia”, apropriada para testar hipóteses, realizar estudos estatísticos (desde que amparada por dados coletados quantitativamente e devidamente relacionados) ou relatar uma pesquisa institucional. O questionário foi disponibilizado em ambiente virtual, desenvolvido em

30 Calazans (Op. Cit.) indica a obra de Harrrington, D. L. e LI, X. Utilizing web-based case studies for cuttingedge information services issues. Reference and User Services Qurtely, 41, 4, Summer, 2002. p. 364. 
plataforma do Google Docs $^{31}$, com links diretos de acesso enviados por e-mail nos convites à participação dos usuários do Portal do Conhecimento Eletrobras Eletronorte (Apêndice C).

A ordem da apresentação das questões no questionário foi diferente da apresentada por alguns pesquisadores. O perfil do usuário não foi antecipando às demais questões. A opção pela alocação das informações de identificação no final do questionário é uma estratégia empregada habitualmente em pesquisas de mercado. A proposta visa priorizar as informações básicas que, de acordo com Malhotra (2008, p. 304), “As informações básicas são da maior importância para o projeto de pesquisa e devem ser obtidas em primeiro lugar, antes de corrermos o risco de alienar os entrevistados formulando uma série de perguntas pessoais". são mais importantes por estarem relacionadas ao problema de pesquisa. Depois, seguem as características socioeconômicas e demográficas para classificar os entrevistados; e as questões de identificação (não utilizadas neste estudo). Desta forma, os pesquisados respondem à última seção com mais rapidez, visto que estão falando sobre si mesmos e portanto não necessitam refletir sobre os tópicos abordados, respondendo sem estresse.

O questionário ficou disponível para preenchimento online no período de 16 a 23/08/2013, uma semana a menos do que o planejado, porém o suficiente para se atingir a meta de 30 respondentes. $\mathrm{O}$ mesmo foi monitorado diariamente pela pesquisadora. Para dar início ao processo, foi enviada mensagem de correio eletrônico assinada pela gestora da área (GAE) na forma de informativo da empresa (Anexo A). Além disso, foi disponibilizado banner com convite à participação no Portal do Conhecimento Eletrobras Eletronorte (Anexo B). No dia seguinte ao envio da mensagem, já havia 13 participações, que foram diminuindo ao longo da semana, o que motivou o envio da segunda mensagem, em 22/08, com o objetivo de aumentar os acessos. Desta forma, atingiu-se o total de 31 respondentes no dia 23, quando foi encerrada a coleta de dados. Vale ressaltar que a amostra foi determinada por limitação de tempo e recursos - tanto humanos quanto financeiros - e decidiu-se, em conjunto com a equipe gestora do portal, considerar a população dos 1.726 funcionários da sede, em BrasíliaDF, que foram indicados por serem, potencialmente, os usuários que mais acessam o Portal do Conhecimento.

\subsubsection{Pré-teste}

31 A plataforma Google Drive permite a elaboração de formulário on-line, de maneira simples e rápida, além de auxiliar na tabulação dos dados e composição de gráficos para apresentação dos resultados. Disponível em < http://www.google.com/intl/pt-BR/drive/apps.html\#forms>. 
No intuito de verificar o valor do instrumento, minimizar erros de construção e compreensão das questões, aplicou-se o pré-teste em um grupo semelhante ao universo pesquisado. $\mathrm{O}$ pré-teste pode revelar a necessidade de fazer modificações no instrumento, o que demandaria novo pré-teste para validação do novo conteúdo do instrumento (TOMANICK, 2004). Diante deste contexto, o pré-teste ao questionário foi aplicado também via plataforma digital, com acesso por convite enviado a sete pessoas por correio eletrônico, disponível para preenchimento no período de 04 a 07/07/2013. Deste total, houve três respondentes que validaram a construção do instrumento sem alterações significativas.

No entanto, ao apresentar o questionário à equipe de profissionais da GAE, gestores do Portal do Conhecimento da Eletrobras Eletronorte, houve algumas considerações para o processo de coleta de dados como um todo, antes da submissão ao público-alvo, quais sejam:

a) Sem siglas no questionário - devido a existência de vários portais, para evitar confusões, solicitaram não utilizar siglas para o Portal do Conhecimento. Da mesma forma, indicaram o uso de imagens captadas do portal (tela principal e cabeçalho) de forma a ampliar a percepção para o respondente sobre o objeto de análise;

b) Outras alterações no questionário - substituir o termo gestor por gerente; usar alternativa de gênero "usuário(a)"; alterar os cargos para atender à classificação utilizada na empresa (cargos de nível fundamental, nível médio operacional; nível médio suporte e nível superior);

c) Divulgação da pesquisa - envio de convite para participação via mensagem de correio eletrônico, enviada pela área gestora do sítio, que aconteceu em 16/08/2013, e foi repetida em 22/08/2013. Inclusão dos nomes da UCEL e UnB para indicar parceria na realização do projeto (reforço de credibilidade);

d) Acesso à pesquisa - disponibilizar link de acesso à pesquisa no corpo da mensagem-convite e outro em banner específico, afixado no próprio portal, a ser confeccionado pelo webmaster;

e) Período da pesquisa - ficou acordado a semana de 14 a 21/08/2013. No entanto, problemas operacionais levaram à realização apenas no período de 16 a 23/08/2013. A mensagem de e-mail iniciou o processo de coleta.

Outra contribuição da equipe foi destacar o único filtro existente no instrumento: a importância de ser usuário do portal, condição que anteriormente integrava o texto de abertura, mas, por sugestão dos gestores foi dado maior destaque. Diante disso, foi elaborado 
um recurso gráfico que permitiu valorização da mensagem (e funcionou como espécie de banner), alocado logo abaixo do texto de apresentação, tornando-o bastante visível.

Figura 21 - Destaque ao único filtro do questionário, disponibilizado na parte introdutória.

Atenção: se você não é usuário do Portal do Conhecimento da Eletronorte, por favor,
não responda a este questionário.

Fonte: elaboração própria.

Figura 22 - Cabeçalho aplicado em cada seção do questionário (identificação).

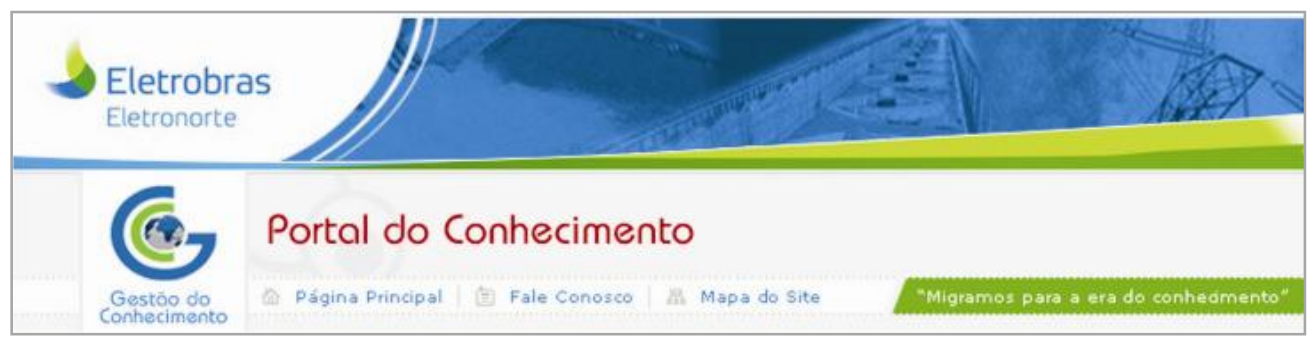

Fonte: Portal do Conhecimento Eletrobras Eletronorte.

Figura 23 - Reprodução da tela inicial do portal, usada no questionário.

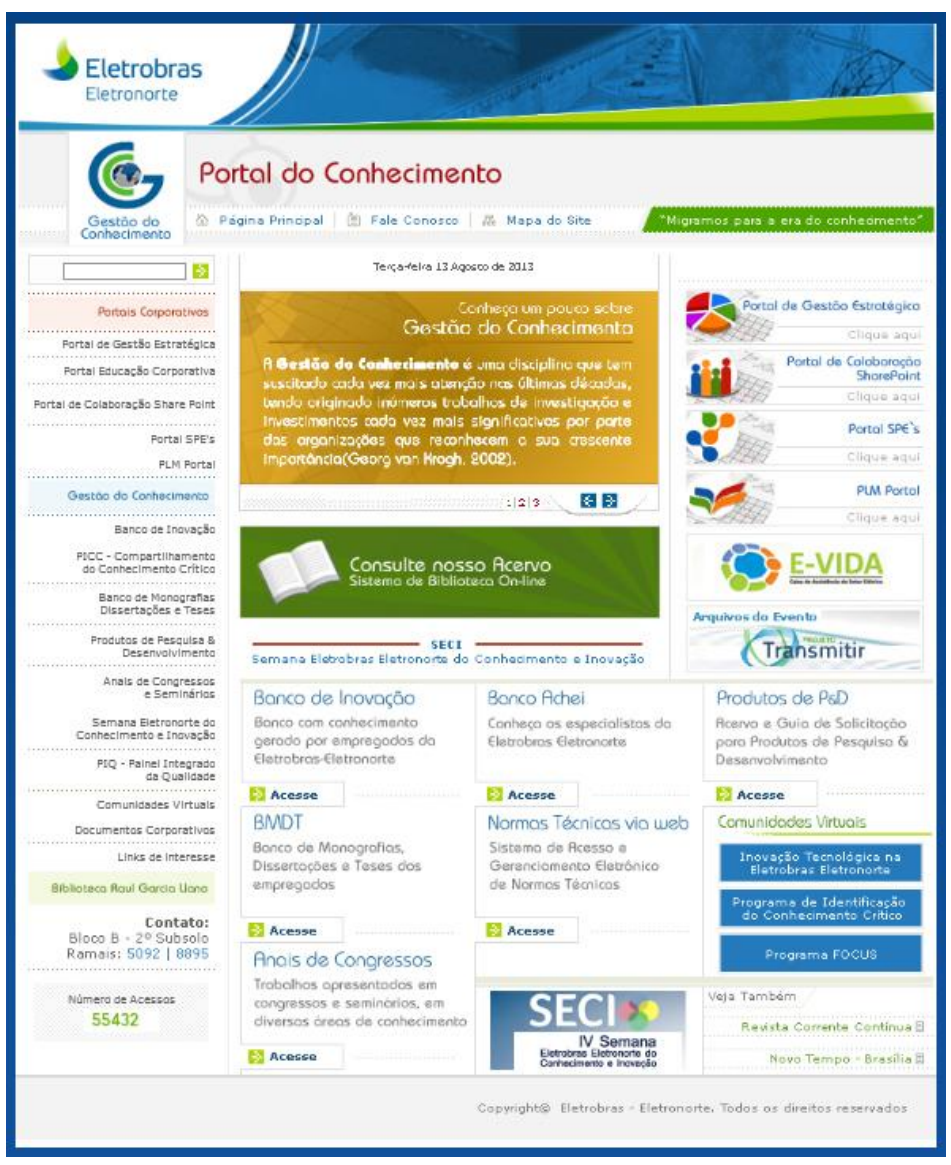

Fonte: Portal do Conhecimento Eletrobras Eletronorte 


\subsection{REFERENCIAL TEÓRICO}

Esta parte do trabalho visa descrever a abordagem teórica que fundamenta o entendimento do problema e direciona as ações necessárias para a investigação propriamente dita com vistas ao atendimento dos objetivos propostos.

Conforme descreve Gasque (2008b, p. 108), o referencial teórico embasa a interpretação do problema da pesquisa, "uma versão do mundo que permite revisão, avaliação e reconstruções contínuas". No referencial teórico, o pesquisador deve relacionar os conceitos principais para o desenvolvimento da pesquisa, devidamente amparado pela linha de pesquisa e teorias adotadas.

Este estudo pretende contribuir para maior compreensão sobre o comportamento de pesquisa dos usuários de Portais de Corporativos com vistas à tomada de decisões. Sob este aspecto, elegeu-se alguns conceitos essenciais abordados no estudo, apresentados a seguir.

\subsubsection{Conceitos da pesquisa}

As perspectivas teóricas abordadas no estudo privilegiam o contexto da informação necessária à composição do conhecimento organizacional e como este pode gerar vantagem competitiva quando utilizado eficaz e eficientemente. Para tanto, enfatiza-se a importância da pesquisa da informação em mídias que ampliem o desempenho de busca do usuário que, devidamente capacitado para realização da atividade de busca, compartilhamento e uso da informação pesquisada, gera resultados satisfatórios para os atores - o indivíduo, a organização e o ambiente de negócios.

A seguir, descrevem-se os conceitos essenciais que embasam a realização do estudo, dentro do enfoque da Ciência da Informação e pertinentes ao ambiente da pesquisa. Por último, explora-se o modelo conceitual proposto para a pesquisa da informação em portal corporativo.

\section{Informação e compartilhamento do conhecimento}

Informação é um termo polissêmico, cujo conceito varia conforme a abordagem (WERSIG; NEVELING, 1975). A proposta de Brookes (1980) descreve a informação como a estrutura que compõe o conhecimento. Davenport (2003) afirma que a informação é fundamentada por dados, e torna-se mais valiosa ao transformar-se em conhecimento, o que a 
torna mais difícil de administrar. De acordo com o autor, o conhecimento pode ser incorporado em máquinas, mas não o conhecimento tácito (aquele que está na mente de cada ser humano). Este é bastante difícil de categorizar, localizar ou mesmo gerenciar, motivo pelo qual as organizações usam sistemas e incentivam lideranças e liderados para desenvolver, armazenar e transferir informações entre si e o ambiente de negócios, de forma contínua, proporcionando a geração de conhecimento organizacional (SGUARIO; TOMAÉL, 2011). Portanto, o emprego eficaz da informação pode gerar valor agregado aos produtos e serviços da organização, proporcionando-lhe vantagem competitiva.

A gestão da informação possui particularidades que devem ser consideradas (BEAL, 2007), por se referir a algumas características específicas da informação:

a) a informação é compartilhável - o valor da informação aumenta com o uso;

b) a informação é perecível (conforme o tempo passa, a informação perde valor);

c) o valor da informação aumenta com a precisão e quando há combinação de informações;

d) a utilidade da informação é definida por critérios identificados pelo usuário, tais como relevância, qualidade da apresentação e quantidade;

e) a informação é multiplicável por processos como síntese, combinação e análise.

\section{Comportamento informacional e comportamento de pesquisa da informação}

No trabalho, considera-se comportamento informacional uma denominação mais ampla para o estudo de necessidades, busca e uso da informação (GASQUE, 2008b). O comportamento informacional abrange os conceitos abordados por Wilson (2000), tais como:

a) necessidades de pesquisa da informação;

b) variáveis que intervém no comportamento de busca da informação (como barreiras econômicas e características pessoais do usuário da informação);

c) processamento e emprego da informação;

d) a transferência da informação.

Além desses, Gasque (2008b) inclui os estudos dos métodos para verificação destas atividades.

De acordo com Wilson (1981), o termo busca de informação tem sido empregado como abreviação para inúmeras atividades, e que a maioria das pesquisas tende a salientar a sua natureza intencional e baseada em problemas. O comportamento de busca da informação envolve, muitas vezes, as ações de pesquisa da informação, compreendida como 
comportamento de busca da informação em nível mais detalhado. Nesta parte do trabalho são contemplados os principais conceitos que nortearam a pesquisa, sendo considerados aqueles que atendem ao objeto da investigação, quais sejam:

a) Comportamento informacional - abrange o todo do comportamento humano quanto ao uso de fontes e canais de informação. Engloba subcategorias: atividades de busca, pesquisa e uso da informação;

b) Comportamento de pesquisa da informação - comportamento de busca da informação em nível mais detalhado, por relacionar o indivíduo como usuário de diversos sistemas de informação e que, no caso deste estudo, está representado como objeto de pesquisa - o Portal do Conhecimento Eletrobras Eletronorte.

Pode-se identificar essa inter-relação entre os conceitos utilizados na área no modelo geral de busca da informação proposto por Wilson (1981). Para o autor, a pessoa, o papel social que ela desempenha e o contexto ambiental em que está inserida provocam uma necessidade de informação que impele o comportamento de busca da informação. Na proposta de Wilson, os fatores que influenciam a conduta do usuário na busca da informação também funcionam como barreiras no processo, conforme pode-se constatar na Figura 24.

Figura 24 - Modelo de comportamento de busca da informação.

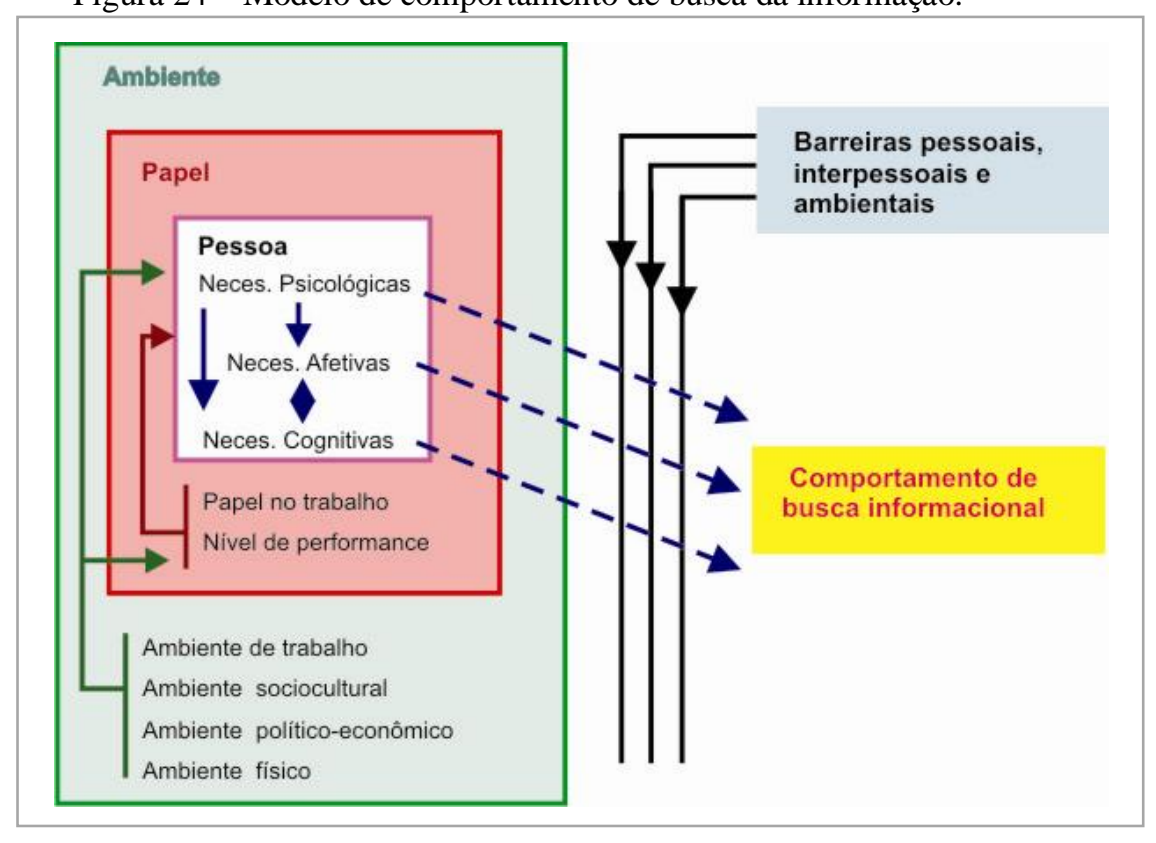

Fonte: Wilson (1981, p. 47).

Apesar de, em artigo posterior, Wilson (2000) rever parte dos conceitos devido ao surgimento de novos fatos, tais como o comportamento de busca da informação em equipe, a 
escrita colaborativa e a procura de informação na internet, optou-se pelo uso do modelo original, de 1981, por ser mais abrangente e referir-se diretamente ao comportamento de busca da informação de indivíduos, identificando o que influencia e as potenciais barreiras que atuam no processo.

Importante considerar a busca de informação de acordo com Courtright (2007), como um processo interativo, que varia ao longo do tempo e do contexto em que está inserida, destacando a influência de diversos fatores na análise do contexto: institucionais e tecnológicos (variáveis externas) que influenciam a ação, tais como o papel desempenhado; os recursos de informação à disposição dos atores (como bibliotecas, livrarias e agências de informação); o meio cultural e os fatores sociais (rede e capital social, normas e colaboração no trabalho); demais aspectos relacionados a ações, problemas, situações e tecnologias disponíveis; dentre outros.

Convém salientar que os modelos de comportamento informacional apresentados por diversos pesquisadores são meios de representação dos processos e das relações existentes quando os usuários buscam e usam a informação em determinado contexto. Estes modelos viabilizam a compreensão do problema e as potenciais interferências no processo, tornando o todo mais didático e até mais eficaz para embasar outros processos, tais como esta pesquisa (GASQUE, 2008b).

\section{Letramento informacional}

Letramento informacional refere-se ao processo de aprendizagem para buscar e usar a informação, algo inerente ao ser humano, relativo ao saber selecionar, acessar, organizar, usar informação e gerar conhecimento. O usuário da informação necessita comparar dados; conhecer as políticas da organização, normas de formatação de documentos. Para tomar decisões o indivíduo deve saber, por exemplo, empregar eficazmente os mecanismos de buscas de sistemas de informação, como a internet; produzir bons textos; elaborar projetos e implementá-los (GASQUE, 2012).

O Conhecimento nas organizações é fruto da atividade das pessoas trabalhando juntas, compartilhando experiências e construindo significados. Para interpretar ou monitorar os ambientes, os gestores precisam ter competência na busca e emprego da informação qualificada (CHOO, 2006). 


\section{Portal corporativo}

Os portais corporativos atendem à demanda por informação qualificada, com o diferencial de disponibilizar meios de colaboração, que permitem aos funcionários interagir na construção e disseminação do conhecimento organizacional (SALDANHA, 2012). Além disso, possuem a capacidade de integração de sistemas heterogêneos em uma única aplicação, como proposta de se tornar "a porta de entrada" para os sistemas de informação da organização (DIAS, 2001b). Os portais corporativos são ferramentas essenciais para o processo de tomada de decisão eficaz, por centralizarem o acesso aos principais recursos informacionais e de conhecimento da organização (MORESI; MENDES, 2010).

Dias (2001b) propõe requisitos mínimos que caracterizam um portal corporativo, os quais foram agrupados em elementos mensuráveis para melhor organização da informação, com objetivo de orientar o desenvolvimento do questionário. Parte dessas características se transformaram em variáveis a serem analisadas, outras foram desconsideradas porque não estão relacionadas ao objetivo deste estudo.

Quadro 7 - Variáveis do portal do conhecimento analisadas no estudo.

\begin{tabular}{|l|l|}
\hline Conceito em relação ao usuário & Requisitos do portal corporativo \\
\hline $\begin{array}{l}\text { Acesso - facilidade e obstáculos para o acesso à } \\
\text { informação; }\end{array}$ & $\begin{array}{l}\text { - viabilizar a localização das informações; } \\
\text { - viabilizar o gerenciamento do ciclo de vida das } \\
\text { informações; } \\
\text { - permitir o compartilhamento corporativo; } \\
\text { - disponibilizar acesso (geral ou restrito) aos recursos } \\
\text { informacionais da organização, inclusive de forma } \\
\text { dinâmica (atualização constante); }\end{array}$ \\
\hline $\begin{array}{l}\text { Competência - capacidade e habilidade do usuário } \\
\text { para pesquisar, empregar e transmitir a informação; }\end{array}$ & $\begin{array}{l}\text { - prover a classificação e a pesquisa intuitiva; } \\
\text { possibilitar a localização de profissionais na empresa } \\
\text { que sejam especialistas em áreas específicas de } \\
\text { determinados projetos; } \\
\text { - permitir a troca de informações com os stakeholders; }\end{array}$ \\
\hline $\begin{array}{l}\text { Pertinência - atendimento à demanda (aplicação) } \\
\text { da informação pesquisada. }\end{array}$ & $\begin{array}{l}\text { possuir a capacidade de satisfazer as necessidades de } \\
\text { informação dos usuários da organização; } \\
\text { ofertar ferramentas inteligentes de negócios } \\
\text { devidamente integradas; }\end{array}$ \\
\hline
\end{tabular}

Fonte: baseada em Dias (2001b).

\subsubsection{Modelo teórico-conceitual proposto}


Com base nos conceitos descritos, optou-se por adaptar o modelo de comportamento de busca da informação proposto por Wilson, em 1981, com a proposta de Dias (2001b) para a caracterização do portal, como se pode observar na Figura 25. Sob este ângulo, procura-se ilustrar como as variáveis de comportamento de pesquisa da informação dos usuários de portais corporativos devem ser consideradas no intuito de ampliar a eficácia e eficiência do processo em portais corporativos.

Figura 25 - Modelo de comportamento de pesquisa de informação em portal corporativo.

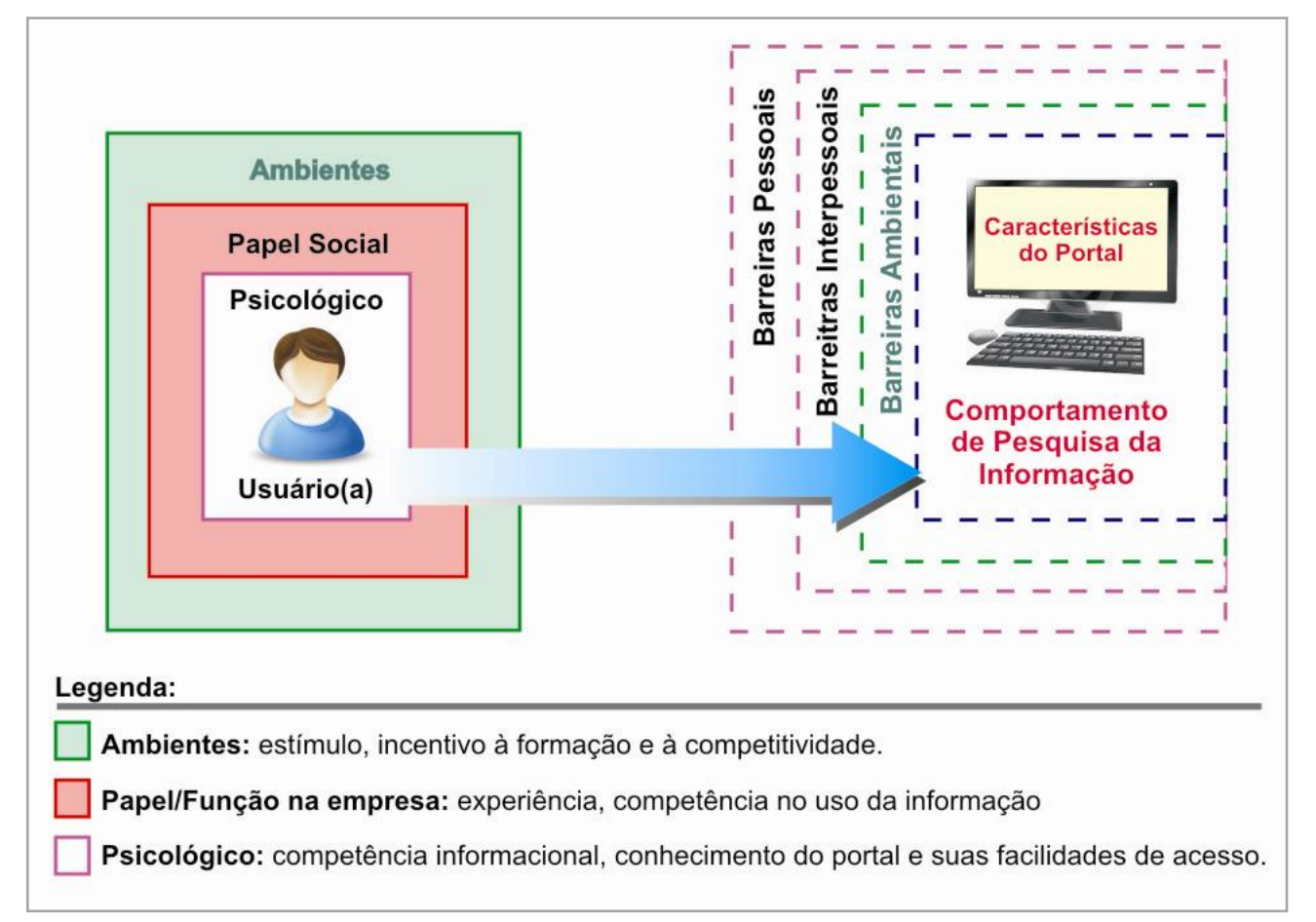

Fonte: adaptado de Wilson (1981).

O referido modelo privilegia a interação dos ambientes de negócios, que influencia tanto o indivíduo, usuário da informação, quanto a organização, responsável direta pelo fornecimento de estímulos na busca pela competitividade. Considera ainda o ponto de vista do usuário e a relação com as variáveis contextuais que influenciam a busca e podem assumir a conotação de barreiras ao processo. Percebe-se, por exemplo, que o papel desempenhado pelo usuário na organização sofre influência da experiência profissional, desenvolvendo habilidades para que ele possa desempenhar atividades operacionais e estratégicas. Para tanto, o usuário necessita saber buscar, selecionar, processar e compartilhar a informação, ou seja, ele depende do letramento informacional e da interação social para construir significados e dar sentido à informação para tomar decisões. Considera-se ainda, os aspectos psicológicos que dialogam com as características do portal, as quais podem colaborar com o processo de 
pesquisa ao facilitar o acesso e apresentar conteúdo relevante que atenda à necessidade de informação do indivíduo.

Desta forma, o modelo proposto, designado modelo de comportamento de pesquisa de informação em portal corporativo, apresenta a importância da interação do indivíduo com o ambiente da informação, evidenciando a ação de influências e potenciais barreiras que podem ser diagnosticadas e trabalhadas para se atingir a eficácia e eficiência do processo de pesquisa da informação qualificada para a tomada de decisão. 


\section{ANÁLISE DE RESULTADOS}

Este capítulo apresenta os resultados obtidos com os instrumentos utilizados na coleta de dados da presente pesquisa, quais sejam, entrevistas com gestores (Apêndices A e B), questionário (Apêndice C) e análise documental. Os dados apresentados foram categorizados e tabulados, viabilizando a avaliação e a combinação das variáveis investigadas, quantitativa e qualitativamente na busca de respostas para a proposição inicial do estudo (CALAZANS, 2007).

\subsection{DADOS COLETADOS POR MEIO DO QUESTIONÁRIO}

O questionário online aferiu questões relacionadas com o acesso do usuário, competência técnica do usuário para realizar a pesquisa de informação, utilidade da informação para a tomada de decisão, compartilhamento da informação pelo usuário. Além destas, foram abordadas a percepção do usuário sobre o processo de pesquisa e a natureza do uso das informações obtidas pelo Portal do Conhecimento, bem como a identificação do perfil do respondente.

A ferramenta Google Docs utilizada na elaboração do questionário permite exportação dos dados em formato de planilhas do tipo Excel (Microsoft Office), o que possibilitou a tabulação dos dados e elaboração de gráficos e tabelas que ilustram as análises a seguir.

Vale salientar que se tomou como princípio na composição dos gráficos e tabelas o mínimo de interferência visual, o que motivou o uso de números inteiros na descrição dos rótulos dos dados, podendo gerar somatória de $99 \%$ ao contrário dos habituais $100 \%$. No entanto, utilizou-se uma casa decimal para diferenciar valores muito próximos, quando a informação exigia maior precisão dos dados.

\subsubsection{Perfil dos respondentes}

A seção identificou as variáveis cargo, nível de escolaridade, função gerencial, tempo de trabalho na e para a Eletrobras Eletronorte, faixa etária e o gênero do respondente. De acordo com a forma de categorização utilizada na empresa para designação dos cargos, podese constatar no Gráfico 1 que 65\% dos participantes da pesquisa ocupa cargos de nível superior e apenas $35 \%$ estão em cargos de nível médio. 
Gráfico 1 - Respondentes, de acordo com o cargo que ocupam na empresa.

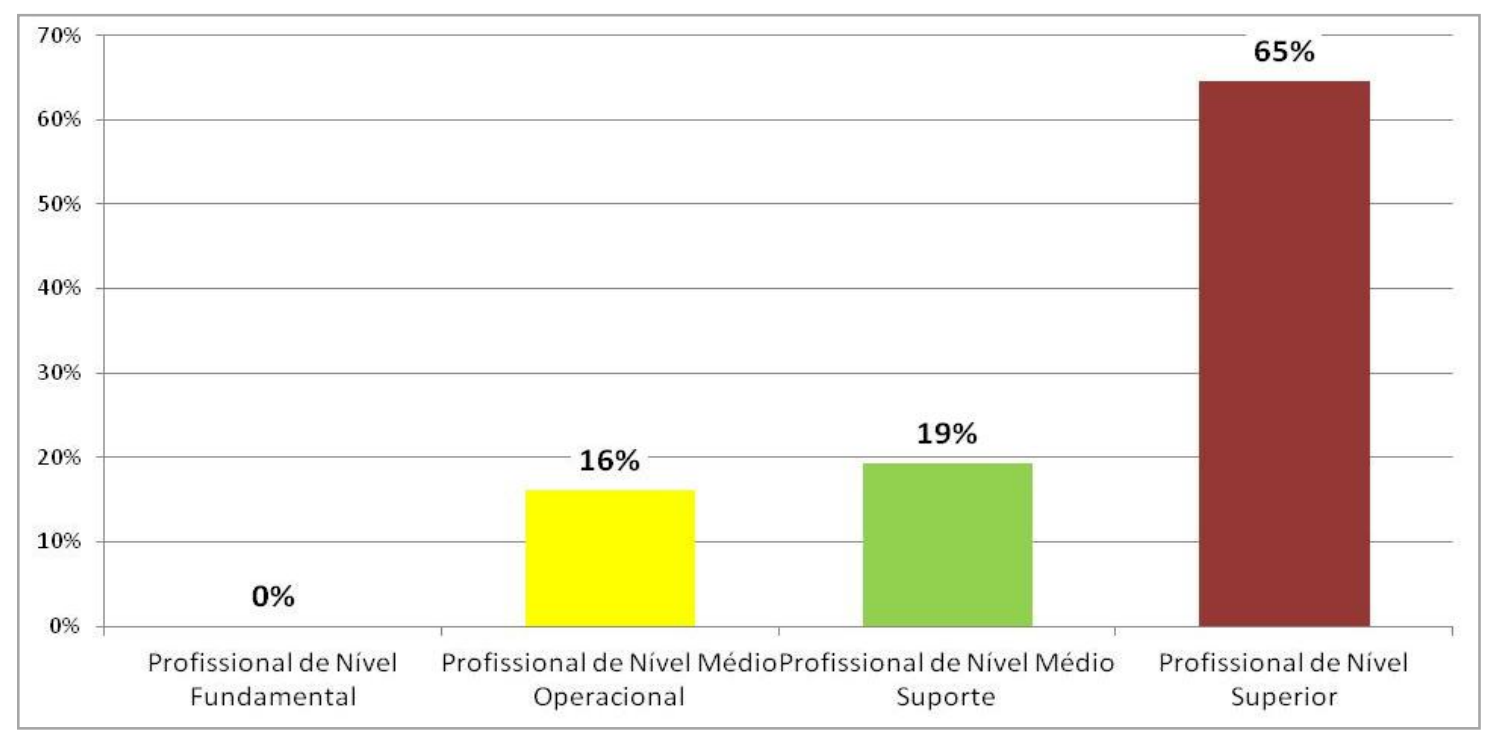

Fonte: elaboração própria.

Em relação ao nível de escolaridade dos respondentes, $90 \%$ possuem ensino superior considerando a graduação completa, especialização, mestrado e doutorado, conforme demonstrado na tabela 1. Pode-se inferir que há diversos profissionais que ocupam cargos não relacionados à atual formação acadêmica, o que pode se constituir em indicativo de que o profissional evoluiu em sua formação independentemente da situação de enquadramento atual na organização.

Tabela 1 - Classificação dos respondentes de acordo com nível de escolaridade.

\begin{tabular}{lc}
\hline Nível de escolaridade (grau mais recente de formação) & Em \% \\
\hline Até o Ensino Médio ( ${ }^{\circ}$ grau). & $6 \%$ \\
\hline Ensino Superior/Graduação em andamento & $0 \%$ \\
\hline Ensino Superior/Graduação Completa & $23 \%$ \\
\hline Especialização em andamento & $0 \%$ \\
\hline Especialização Completa & $58 \%$ \\
\hline Mestrado em andamento & $3 \%$ \\
\hline Mestrado Completo & $6 \%$ \\
\hline Doutorado em andamento & $3 \%$ \\
\hline Doutorado Completo & $0 \%$ \\
\hline
\end{tabular}

Fonte: elaboração própria.

Ainda sobre a questão dos cargos, $13 \%$ dos respondentes atuam em cargos gerenciais na organização, como pode se observar no Gráfico 2. 
Gráfico 2 - Proporção dos respondentes em cargo gerencial.

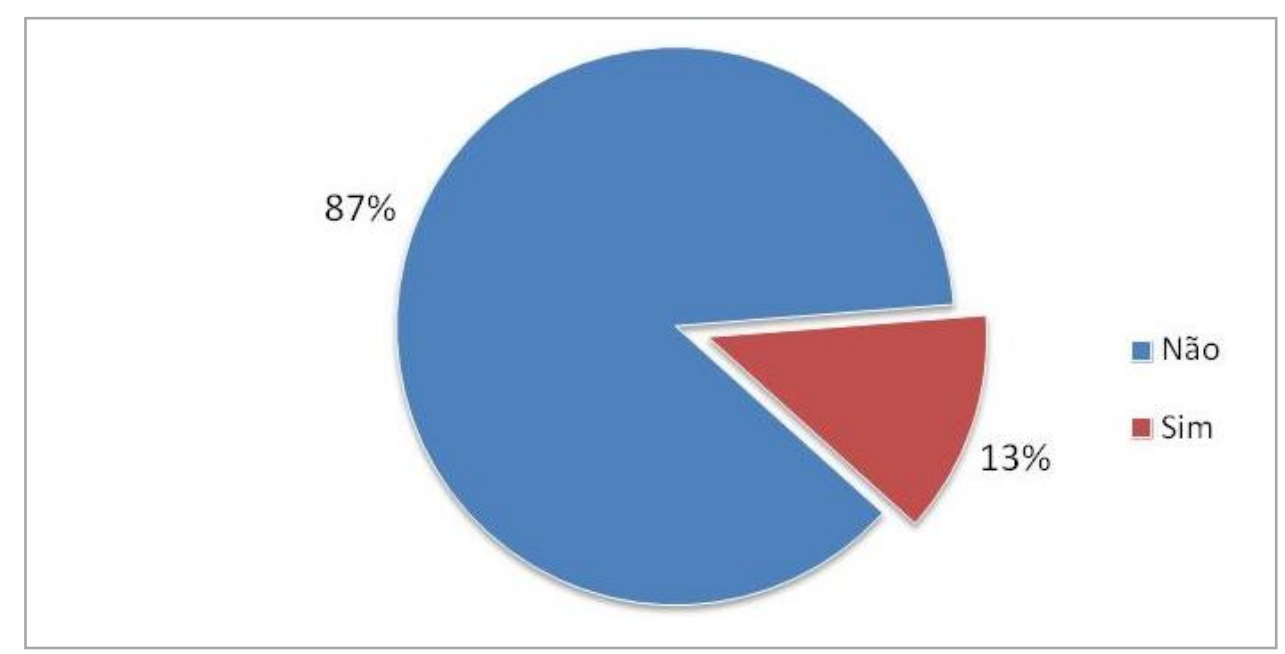

Fonte: elaboração própria.

Outro fator considerado para análise foi o tempo que o participante da pesquisa trabalha na - e para - a Eletrobras Eletronorte, uma vez que o total dos empregados com acesso ao Portal do Conhecimento inclui profissionais terceirizados. O Gráfico 3 demonstra que $61 \%$ dos respondentes possuem mais de 20 anos de empresa, e $26 \%$ estão na Eletrobras Eletronorte entre 6 e 10 anos. Nenhum dos participantes tem menos de um ano, o que ratifica a qualidade da amostra, pois todos conhecem bem a organização.

Gráfico 3 - Classificação dos respondentes quanto ao tempo na Eeltrobras Eletronorte.

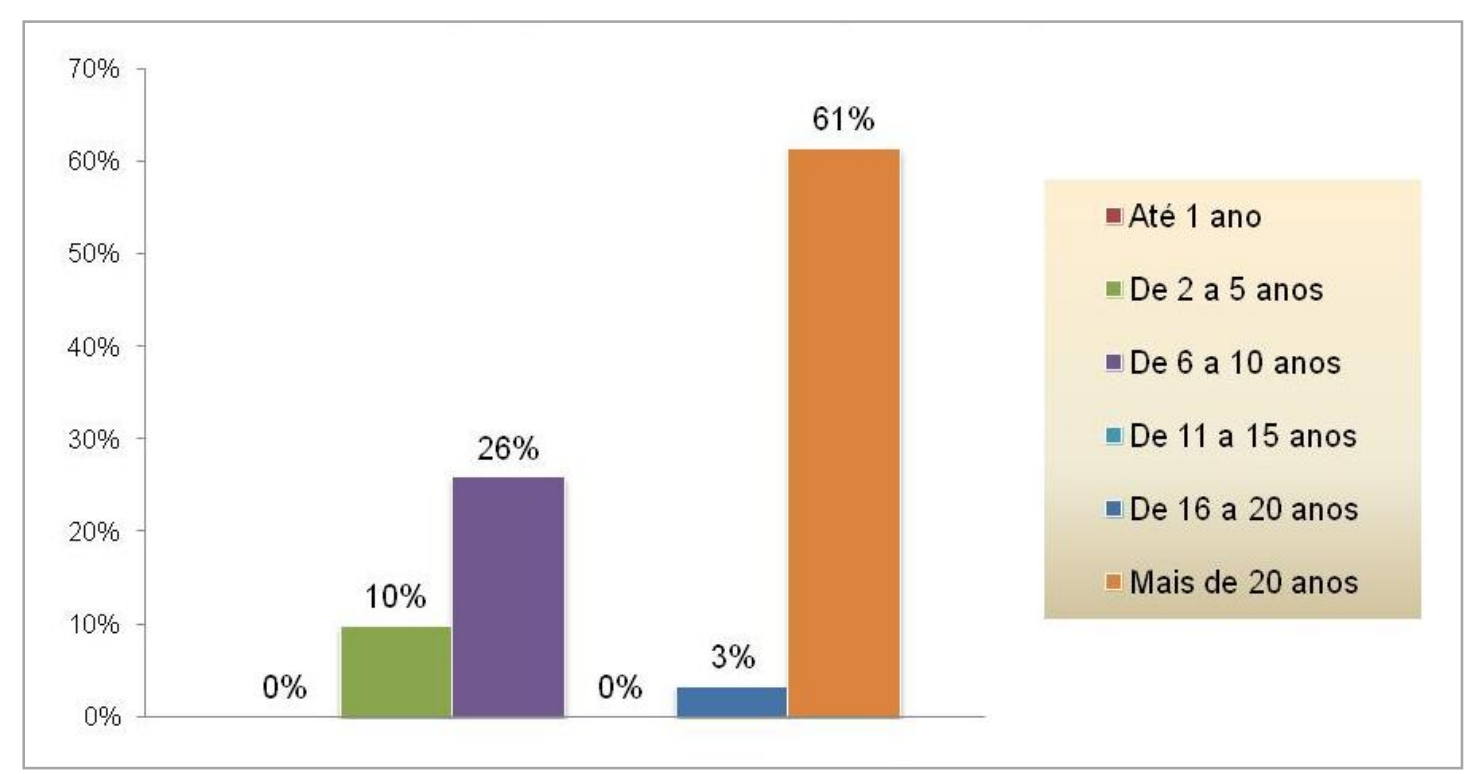

Fonte: elaboração própria. 
Os Gráficos 3 e 4 estratificam a amostra por faixa etária e gênero. Nota-se que $61 \%$ dos respondentes estão acima de 46 anos e não há representação abaixo de 25 anos. Associando-se estes dados ao nível de formação acadêmica, pode-se constatar que a organização possui um quadro de profissionais com muitos anos de prestação de serviços na empresa e que se trata de área ocupada, em sua maioria, pelo gênero masculino (68\%).

Gráfico 4 - Classificação quanto a faixa etária dos respondentes.

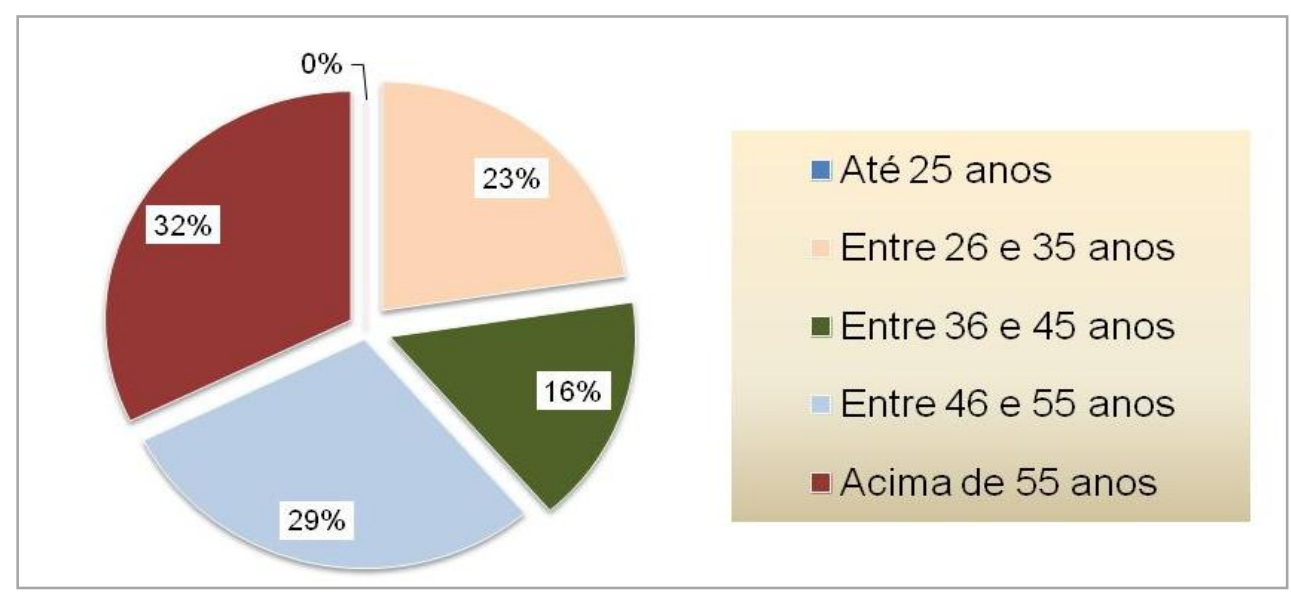

Fonte: elaboração própria.

Gráfico 5 - Classificação dos respondentes quanto ao gênero.

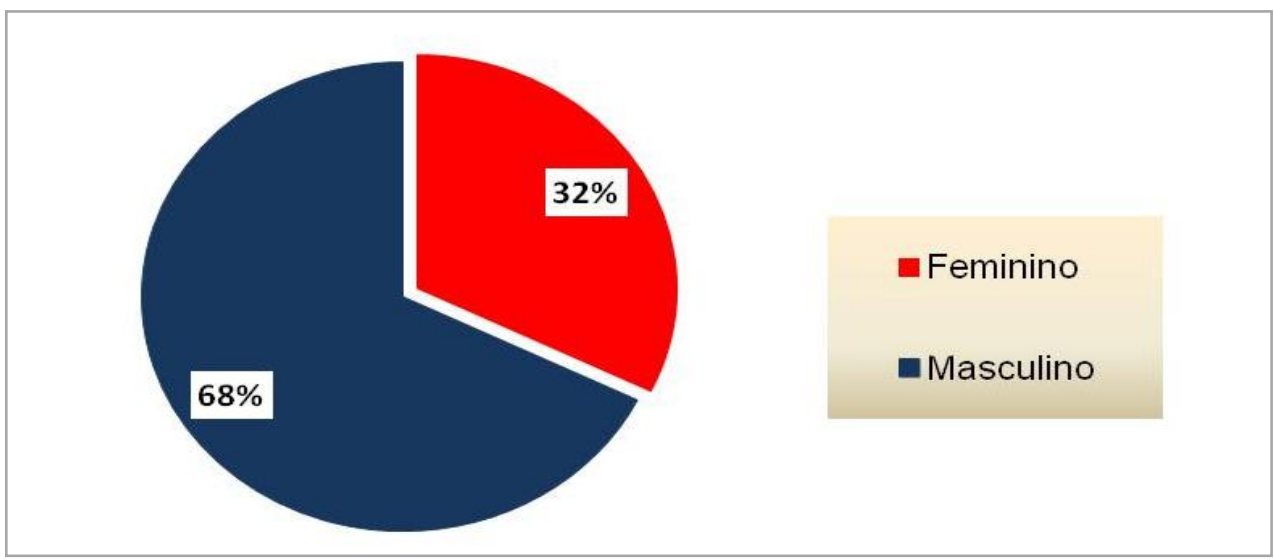

Fonte: elaboração própria.

Vale salientar que a Eletrobras Eletronorte é participante do Programa Pró-Equidade de Gênero e Raça ${ }^{32}$ desde o lançamento no segundo semestre de 2005. Na quarta edição, o

32 O Programa Pró-Equidade de Gênero e Raça é uma iniciativa do Governo Federal, viabilizado pela Secretaria de Políticas para as Mulheres da Presidência da República (SPM/PR) e do Plano Nacional de Políticas para as Mulheres, e tem como objetivo reforçar os compromissos de promoção da igualdade entre mulheres e 
programa é considerado instrumento de gestão empresarial da Eletrobras Eletronorte e está alinhado ao Planejamento Estratégico da organização, por estabelecer novos paradigmas para o desenvolvimento sustentável, incluindo a garantia dos direitos de homens e mulheres a um ambiente de trabalho livre de discriminação - seja de raça, etnia ou orientação sexual. Para tanto, desenvolve atualmente 41 ações distribuídas em seis diretrizes de gestão de pessoas e quatro diretrizes de cultura organizacional.

\subsubsection{Resultados dos acessos dos usuários(as)}

O presente tópico trata das questões relativas ao acesso dos usuário para identificar os fatores que estimulam a busca de informação e possíveis obstáculos. Os resultados obtidos são descritos na mesma ordem apresentada no questionário.

Apesar da reconhecida importância dos conteúdos e de estar em operação desde 2010, o Portal do Conhecimento da Eletrobras Eletronorte ainda é tão acessado. Os dados mostram que $45 \%$ dos respondentes da pesquisa afirmaram que acessam o portal esporadicamente (cerca de seis vezes ao mês) ou muito raramente (cerca de 10 vezes por semestre). Por outro lado, $35 \%$ afirmaram que o acessam com frequência de até duas vezes por semana, como mostra o Gráfico 6.

Gráfico 6 - Frequência de acesso ao portal do conhecimento Eletrobras Eletronorte.

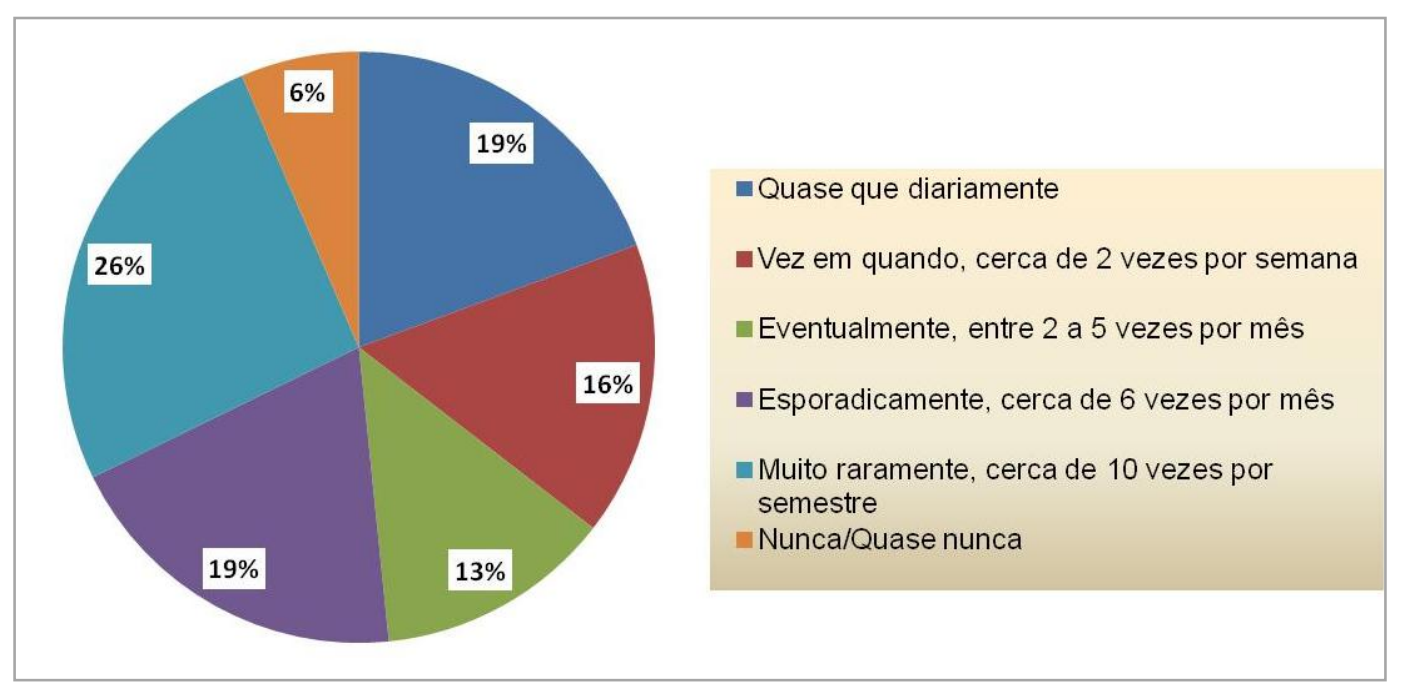

Fonte: elaboração própria.

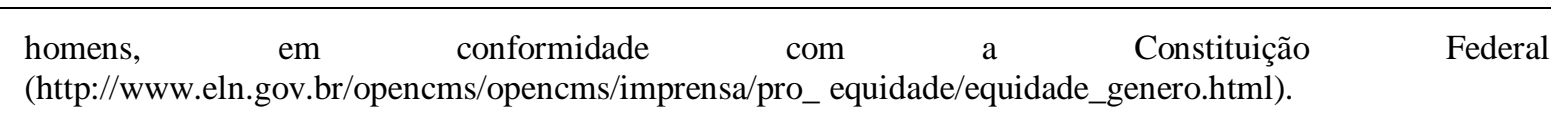


O portal possui média de 370 acessos mensais, correspondente a aproximadamente $10 \%$ do número de funcionários administrativos e técnicos que trabalham na organização distribuídos na sede e demais regionais - atualmente são 3.770 funcionários só na Eletronorte, sem contar com parceiros e terceirizados. Apesar da média frequência, o usuário localiza e acessa facilmente a informação qualificada - expressão utilizada em algumas questões do instrumento em referência à informação que apoia o processo de tomada de decisão em situações rotineiras ou estratégicas. Pode-se constatar no Gráfico 7 que $87 \%$ dos respondentes afirmam localizar informações qualificadas sem dificuldades.

Gráfico 7 - Localização das informações qualificadas com facilidade.

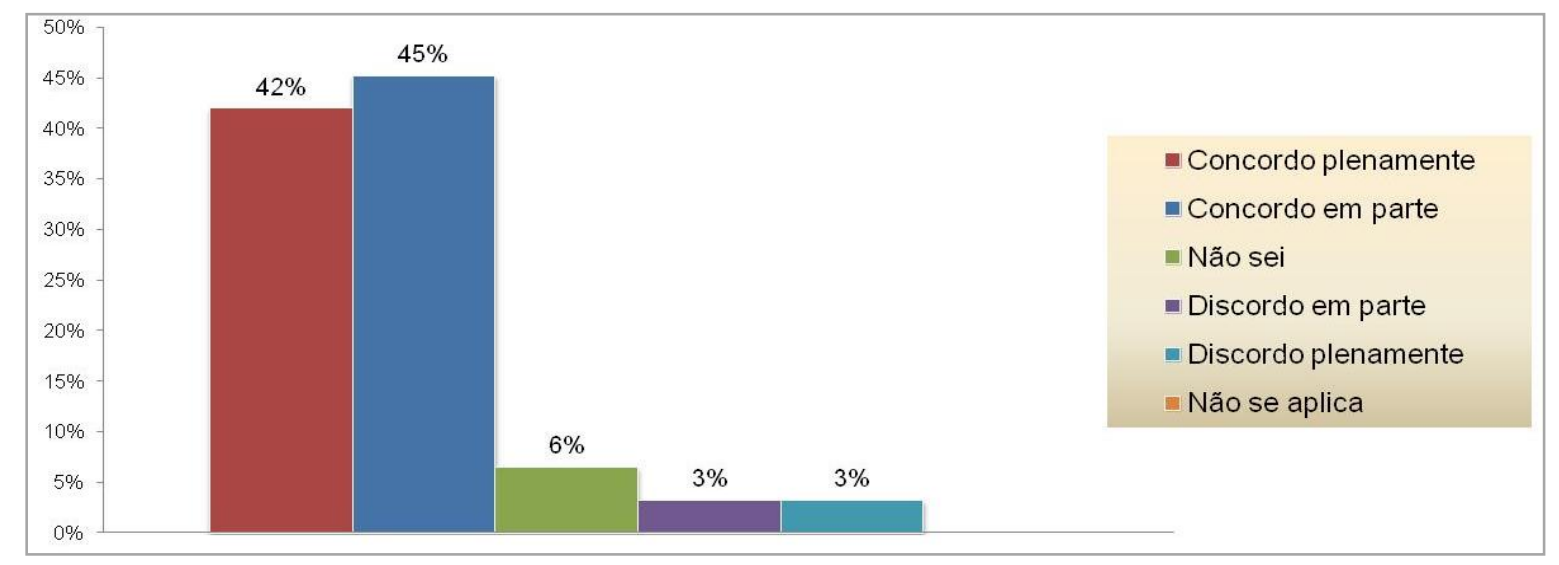

Fonte: elaboração própria.

Complementando este dado, o Gráfico 8 mostra que $84 \%$ dos pesquisados indicaram facilidade para acessar informações no portal, provavelmente por acessarem de máquinas previamente autorizadas e com acesso definido.

Gráfico 8 - Acesso às informações qualificadas com facilidade.

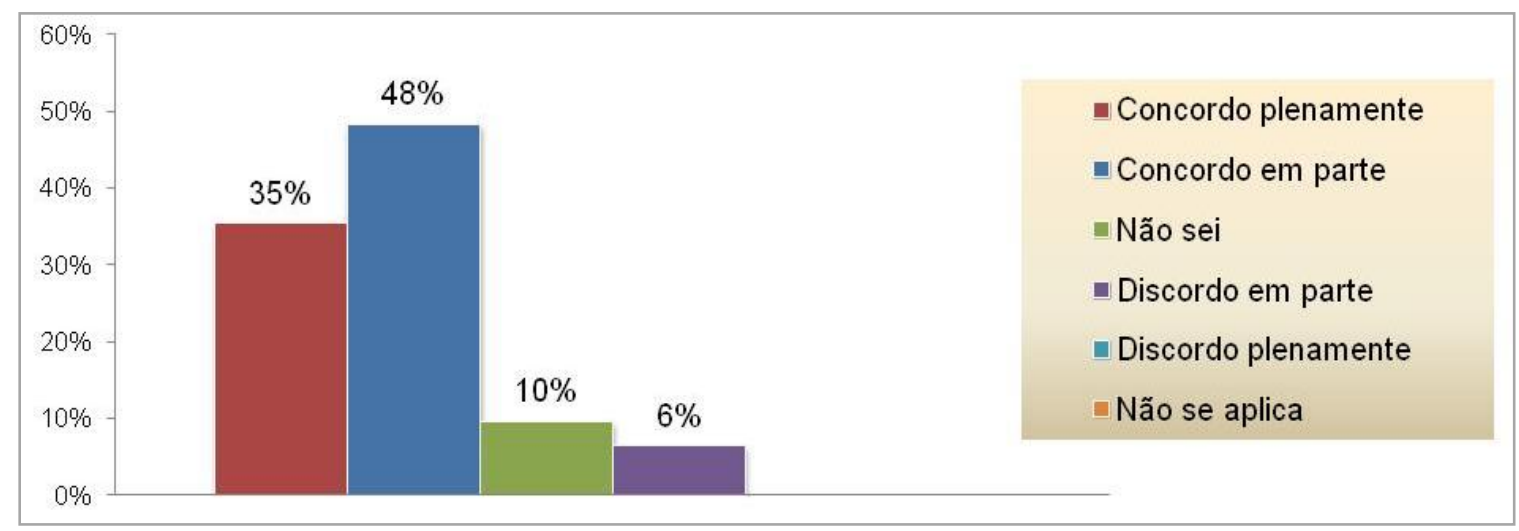

Fonte: elaboração própria. 
Ao serem questionados se encontram no Portal do Conhecimento informações e documentos que necessitam para exercer suas atividades profissionais, 71\% dos respondentes, considerando-se apenas as respostas de concordância, afirmaram que conseguem, como podese verificar no Gráfico 9. Por outro lado, 23\% dos pesquisados discordam em parte da afirmação, o que pode ser um indicador de dificuldade do usuário fazer a pesquisa da informação que necessita.

Gráfico 9 - Encontra informações e documentos para uso nas atividades profissionais.

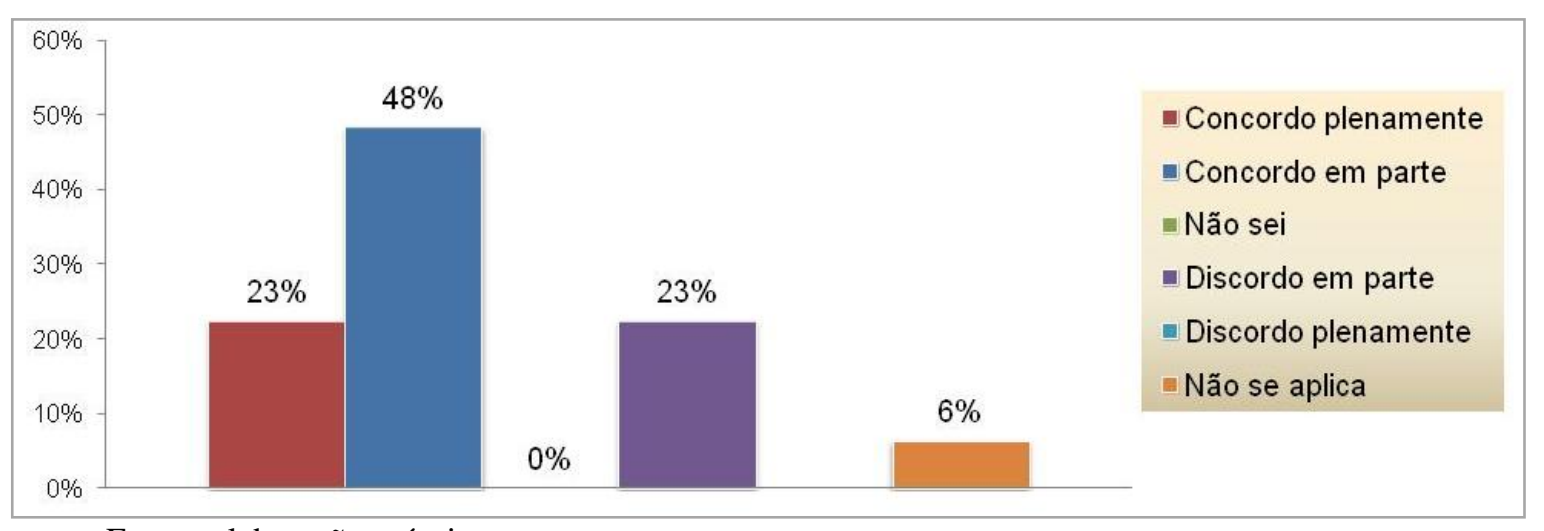

Fonte: elaboração própria.

Ratificando a importância do portal para as atividades dos profissionais da Eletrobras Eletronorte, observa-se pelo Gráfico 10, que $61 \%$ dos respondentes utilizam informações e documentos que compõem o conteúdo do portal para tomarem decisões. No entanto, $19 \%$ dos pesquisados discordam da afirmação, o que merece atenção por parte dos gestores sobre o real motivo de não usarem informações e documentos do portal para a tomada de decisão. Vale ressaltar que a questão das dificuldades da pesquisa da informação é tratado no segundo tópico do formulário, cujas respostas são analisadas no próximo item.

Gráfico 10 - Facilidade de localizar informações para a tomada de decisão.

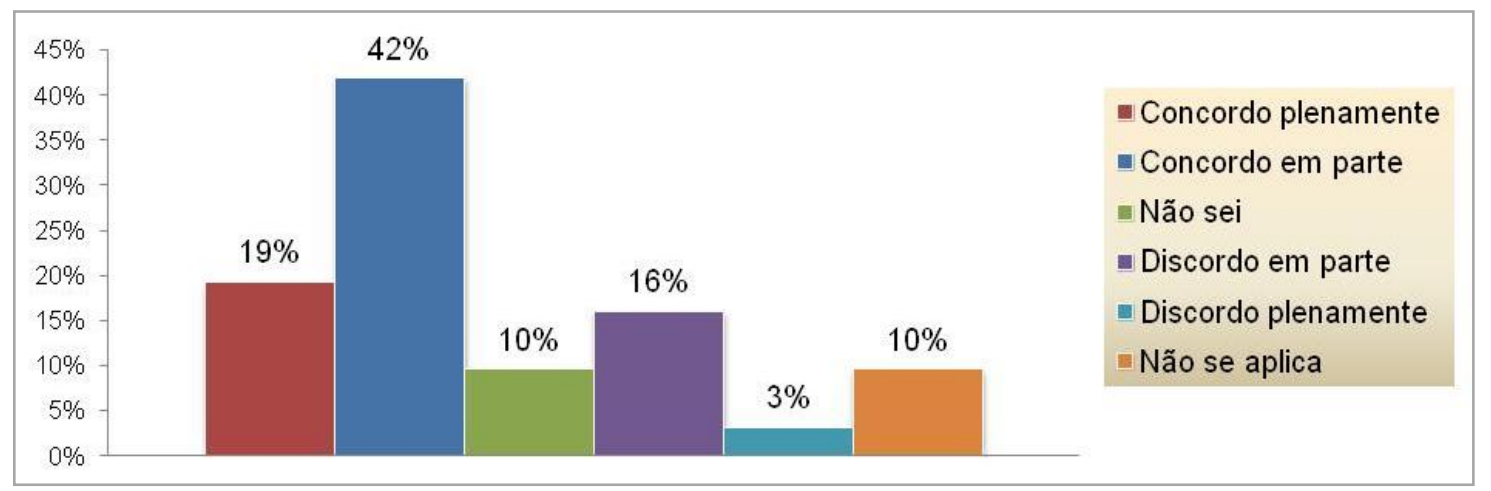

Fonte: elaboração própria. 
Em relação à compreensão do layout das informações, isto é, como as informações estão dispostas no portal, o Gráfico 11 demonstra que $74 \%$ dos respondentes entendem a disposição das informações no portal, sendo que $19 \%$ discordam da proposição, o que pode remeter à dificuldade de pesquisa da informação e/ou em lidar com a ferramenta/tecnologia.

Gráfico 11 - Percepção do layout das informações no portal.

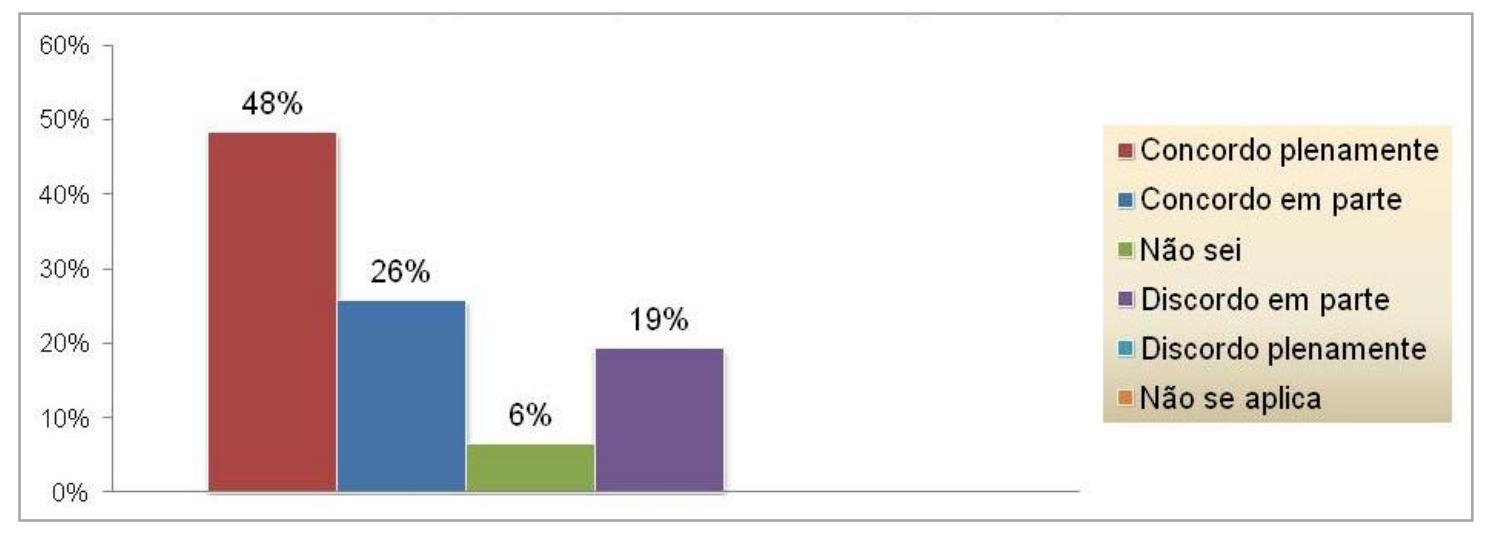

Fonte: elaboração própria.

A questão seguinte do questionário trata das dificuldades encontradas pelo usuário ao pesquisar no portal as informações desejadas. Pode-se verificar na Tabela 2, que 45\% afirmam ter dificuldades para pesquisar as informações no portal e 46\% discordam, praticamente um empate técnico. É curioso notar que $9 \%$ dos respondentes indicaram que não sabem/não se aplica, provavelmente os mesmos que indicaram anteriormente dificuldades de acesso e localização de informações e documentos para exercerem suas atividades profissionais.

Tabela 2 - Classificação de acordo com as dificuldades para pesquisar informações.

\begin{tabular}{lc}
\hline Dificuldades para pesquisar as informações no portal & Em \% \\
\hline Concordo plenamente & $10 \%$ \\
Concordo em parte & $35 \%$ \\
Não sei & $6 \%$ \\
Discordo em parte & $23 \%$ \\
Discordo plenamente & $23 \%$ \\
\hline Não se aplica & $3 \%$ \\
\hline
\end{tabular}

Fonte: elaboração própria. 
Ao questionar sobre a disponibilidade de recursos no portal que facilitam a pesquisa, o Gráfico 12 apresenta que $70 \%$ dos pesquisados reconhecem a existência dos recursos. Outros $30 \%$ dos respondentes não sabem/discordam da proposição.

Gráfico 12 - Disponibilidade de recursos no portal que facilitam a pesquisa informação.

\begin{tabular}{|c|c|c|c|c|c|c|}
\hline $40 \%$ & $35 \%$ & $35 \%$ & & & & \\
\hline $35 \%$ & & & & & & Concordo plenamente \\
\hline $30 \%$ & & & & & & Concordo em parte \\
\hline $25 \%$ & & & & & & Não sei \\
\hline $20 \%-$ & & & & & & Discordo em parte \\
\hline $15 \%$ & & & $10 \%$ & $10 \%$ & $10 \%$ & Discordo plenamente \\
\hline $10 \%$ & & & & & & Não se aplica \\
\hline $5 \%-$ & & & & & & \\
\hline $0 \%-$ & & & & & & \\
\hline
\end{tabular}

Fonte: elaboração própria.

A presente questão analisa a percepção dos usuários sobre a apresentação dos resultados da pesquisa da informação. Observa-se no Gráfico 13, que 67\% consideram adequada a apresentação dos resultados da pesquisa da informação, enquanto $19 \%$ não acham a apresentação compreensível dos resultados. Dos respondentes, 13\% não opinaram, o que compõe o total de $32 \%$ de respostas não favoráveis à compreensão da apresentação dos resultados da pesquisa da informação no portal.

Gráfico 13 - Apresentação (compreensível) dos resultados da pesquisa da informação.

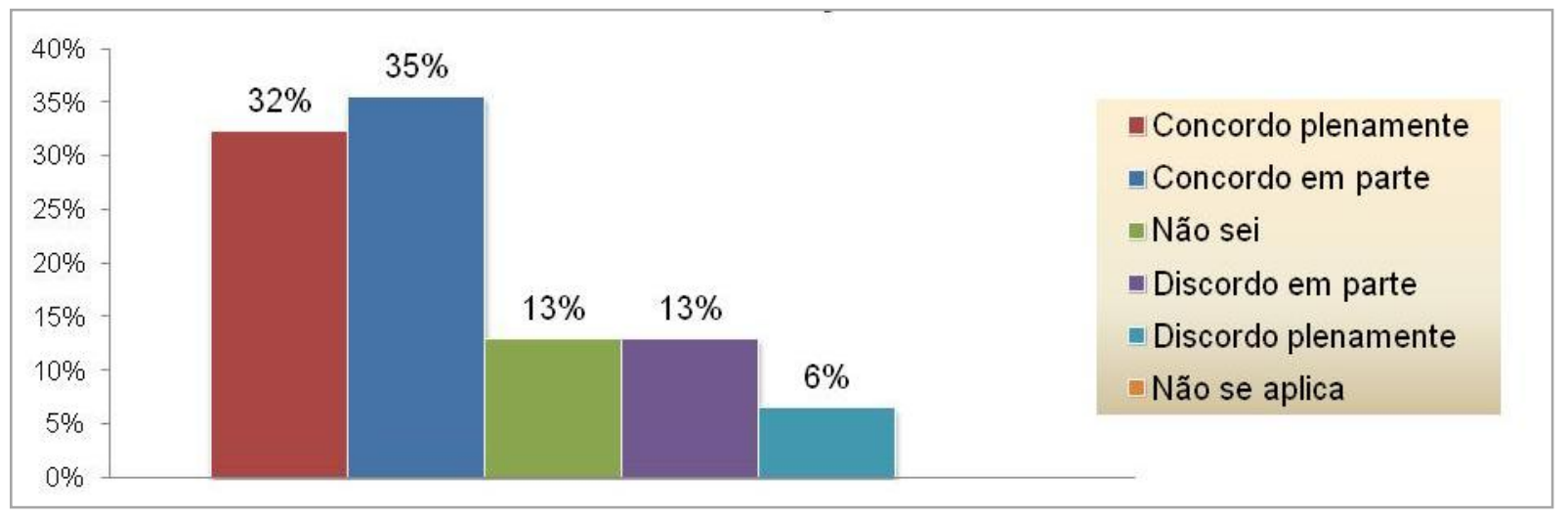

Fonte: elaboração própria.

Os usuários do portal foram questionados sobre a promoção do uso e compartilhamento dos conteúdos no portal. O Gráfico 14 apresenta os resultados, que indicam 
que, $70 \%$ dos respondentes concordam que o Portal do Conhecimento da Eletrobras Eletronorte atende à questão; $10 \%$ se mostraram indecisos e 19\% discordaram. Nota-se que aparecem $29 \%$ dos respondentes que contrapõem à maioria.

Gráfico 14 - Promoção do uso e compartilhamento dos conteúdos.

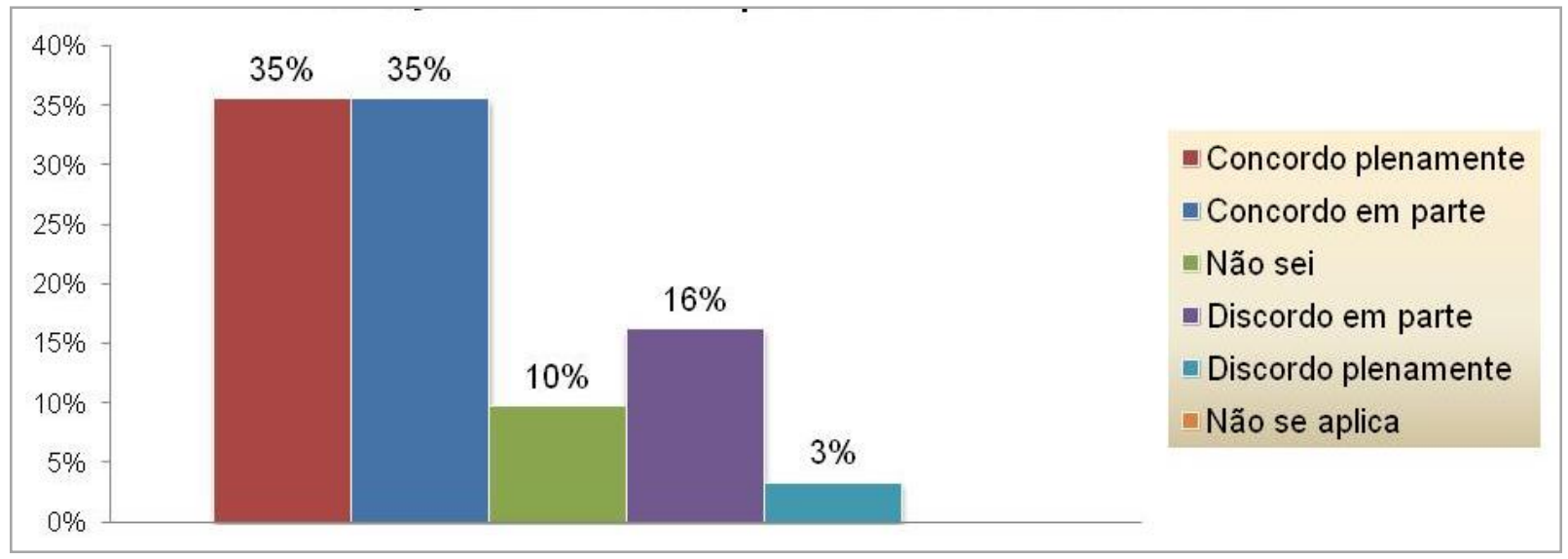

Fonte: elaboração própria.

Quando questionados sobre a participação na produção de novos conteúdos, a maioria dos pesquisados (61\%) concordam que há permissão e/ou estímulo à participação do usuários na produção de novos conteúdos para o portal. Por outro lado, 22\% discordam da questão e $16 \%$ não sabem, como pode-se observar os dados no Gráfico 15.

Gráfico 15 - Permissão/estímulo à participação dos usuários na produção de novos conteúdos.

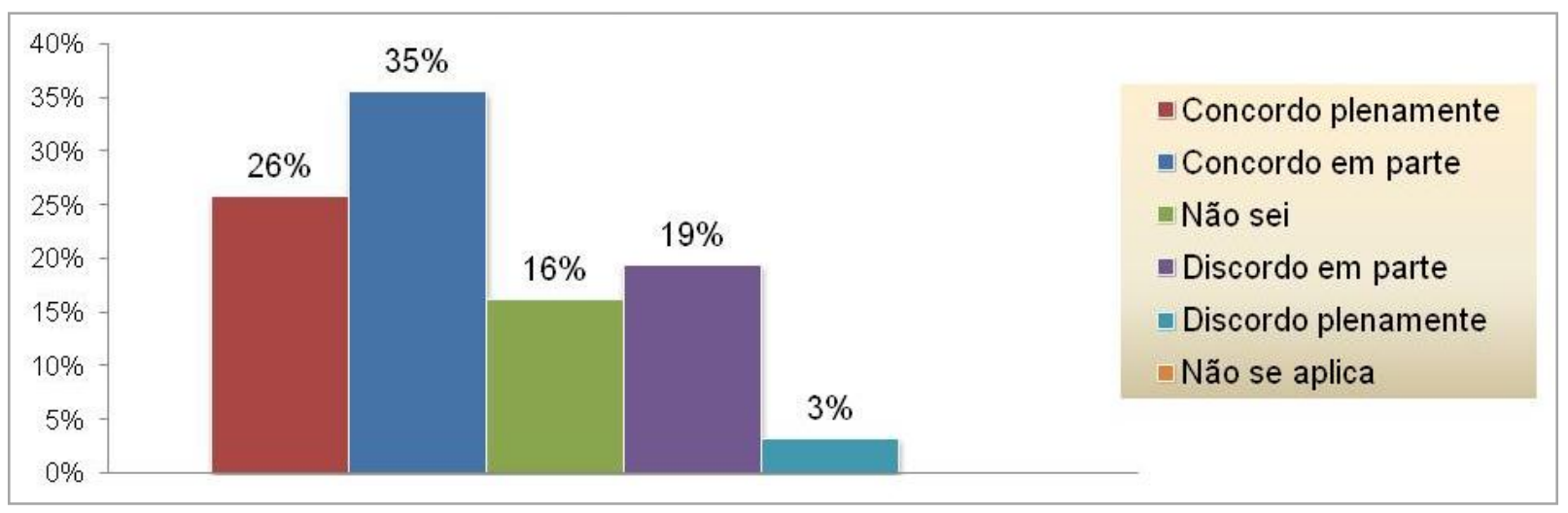

Fonte: elaboração própria.

O Gráfico 16 apresenta os resultados sobre a oferta de meios para facilitar a coleta de ideias, informações e sugestões entre usuários. Dos respondentes, $61 \%$ concordam com a afirmação, $26 \%$ discordam e $13 \%$ responderam não saber se o portal oferece meios que 
facilitam a coleta de ideias, informações e sugestões, provável indicação de que não fazem uso do portal com tal finalidade.

Gráfico 16 - Oferta de meios para facilitar a coleta de ideias, informações e sugestões entre os usuários.

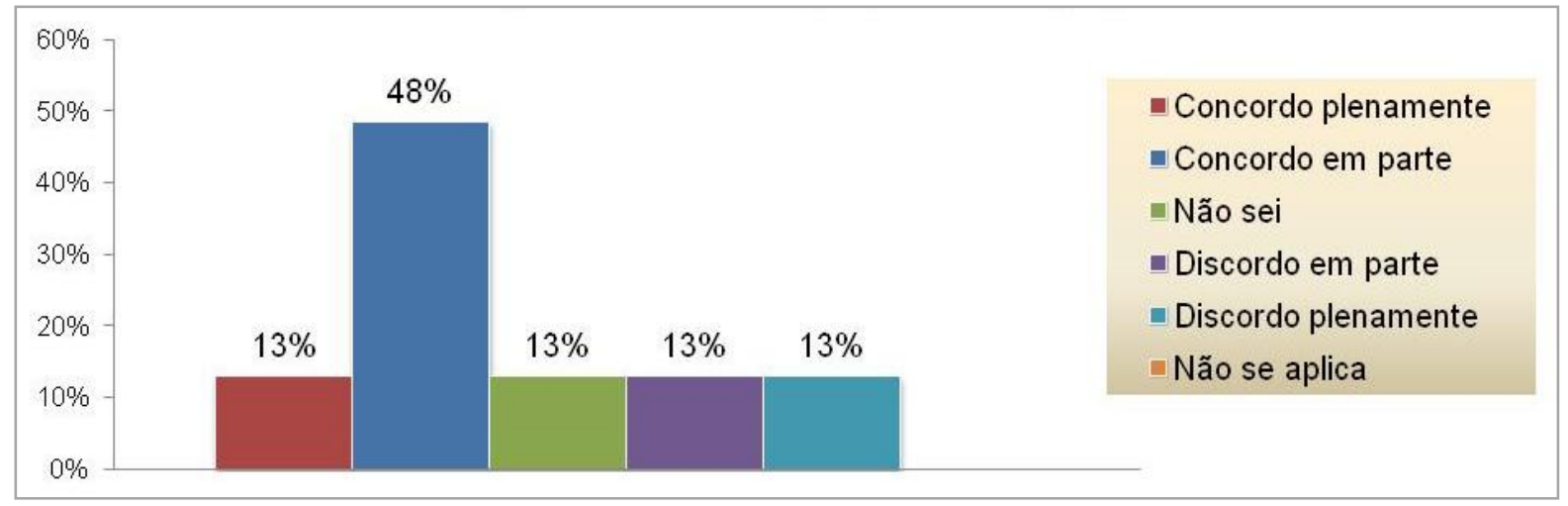

Fonte: elaboração própria.

A divulgação das novas aquisições e novo conteúdo disponibilizado é algo que $81 \%$ dos pesquisados afirmam ocorrer na Eletrobras Eletronorte. Dos respondentes, $12 \%$ discordam e $6 \%$ não sabem. O Gráfico 17 mostra os resultados obtidos.

Gráfico 17 - Divulgação das novas aquisições/novo conteúdo disponibilizado.

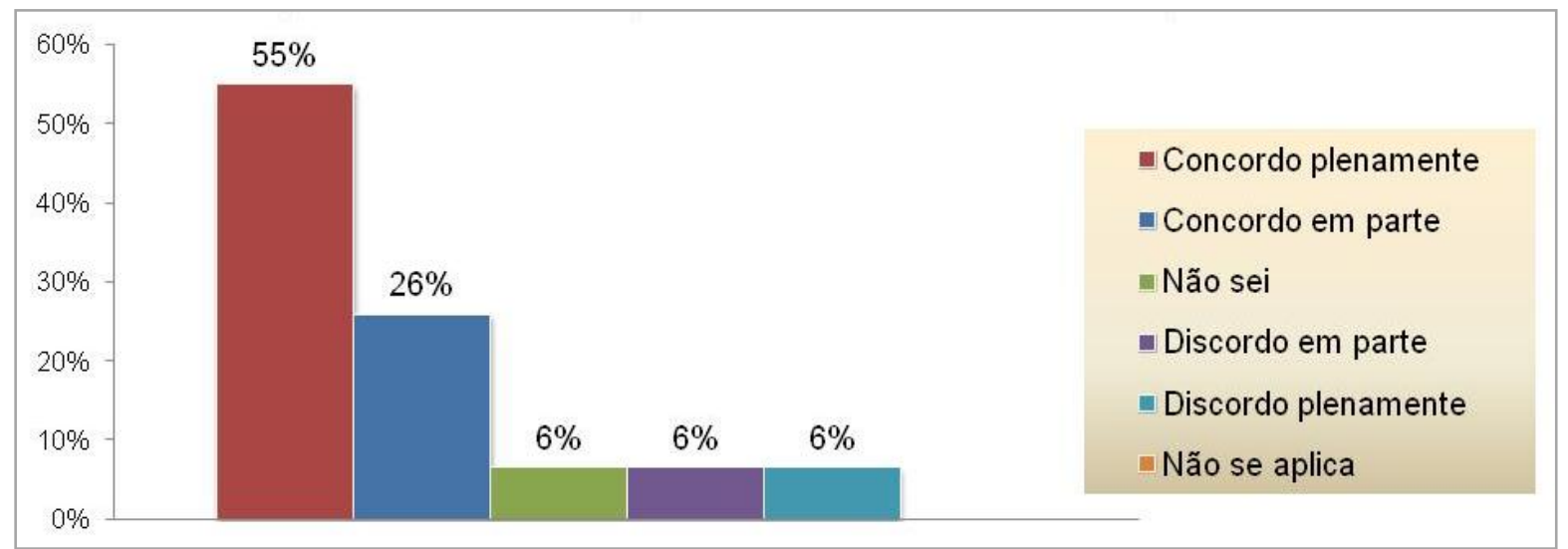

Fonte: elaboração própria.

\section{Considerações finais sobre acessos dos usuários do portal}

Quanto aos acessos dos usuários do Portal do Conhecimento da Eletrobras Eletronorte pôde-se constatar que a ferramenta ainda pode ser mais acessada pelos profissionais da organização, pois quase a totalidade dos respondentes declara ter facilidade para localizar a informação qualificada, bem como para acessá-las. Inclusive, boa parte dos respondentes 
encontra as informações que necessitam para a tomada de decisão, fato que pode ter a influência do layout do portal, que tem aprovação de grande parte dos pesquisados, uma vez que conseguem compreender a organização dos textos e ilustrações dispostos no Portal do Conhecimento.

Por outro lado, quase a metade dos respondentes encontram dificuldades para pesquisar no portal, apesar de boa parte deles reconhecerem a existência de recursos no portal com o propósito de facilitar a pesquisa de informação e que os resultados da pesquisa têm boa apresentação. Aqui pode-se deduzir que a dificuldade para pesquisa pode estar no usuário, em não saber como obter resultados consistentes de pesquisa e empregá-los adequadamente.

Os resultados apontaram também que, grande parte dos pesquisados indicaram que o portal promove o uso e o compartilhamento dos conteúdos disponibilizados, bem como estimula a participação dos usuários na produção de novos conteúdos, o que realimenta o portal e proporciona atualização dos conteúdo. Ainda sobre o compartilhamento, boa parte dos respondentes concorda que o Portal do Conhecimento disponibiliza meios que facilitam a coleta de ideias, informações e sugestões entre usuários. Inclusive, a maioria dentre os pesquisados concorda que são comunicados a respeito de novas aquisições ou de novo conteúdo disponibilizado no portal.

Em relação aos resultados do acesso dos usuários ao Portal do Conhecimento, também pode-se constatar a dificuldade de parte dos usuários em realizar a pesquisa da informação, item a ser analisado na próxima seção.

\subsubsection{Resultados sobre a competência técnica para realizar pesquisa da informação}

O tópico apresenta os resultados sobre a competência técnica do usuário do Portal do Conhecimento para realizar pesquisa de informação no portal. Os resultados estão descritos na mesma sequência das questões do questionário.

Ao serem abordados sobre o conhecimento de técnicas de pesquisa da informação, $52 \%$ dos respondentes afirmaram desconhecer meios que facilitam a busca da informação no portal, como pode-se constatar no Gráfico 18. 
Gráfico 18 - Conhecimento de técnicas que facilitam a pesquisa da informação.

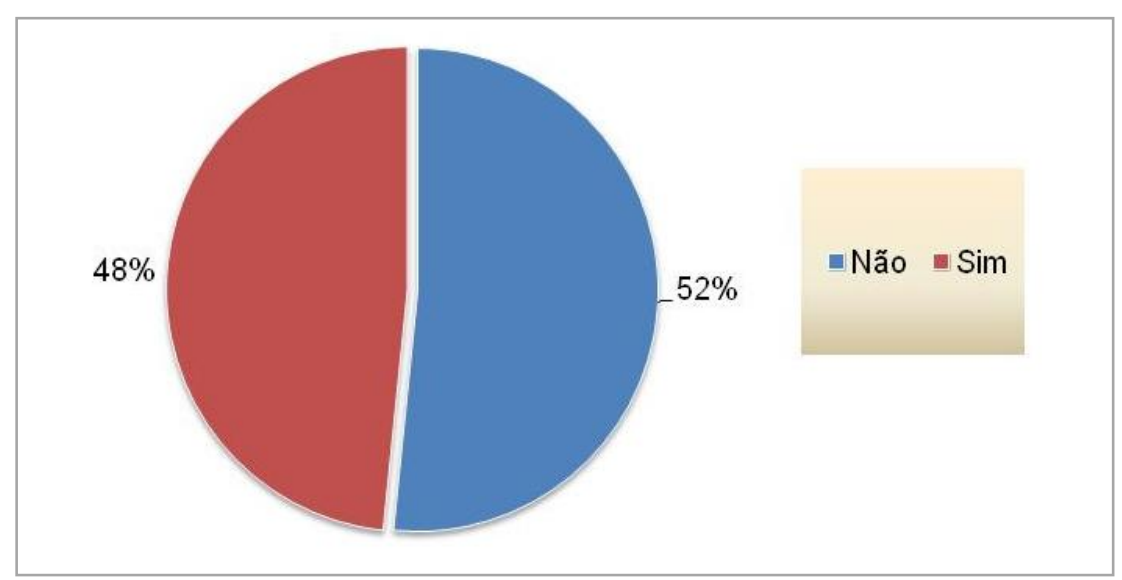

Fonte: elaboração própria.

Sobre a aplicação prática das técnicas 32\% dos respondentes afirmaram usar técnicas próprias para pesquisa da informação, como pode ser constatado no Gráfico 19. Os usuários conseguem localizar e acessar com facilidade a informação/documentos no portal, apesar de alguns reconhecerem a ausência da competência informacional para lidar com processos mais elaborados de pesquisa

Gráfico 19 - Utilização de técnicas que facilitam a pesquisa da informação.

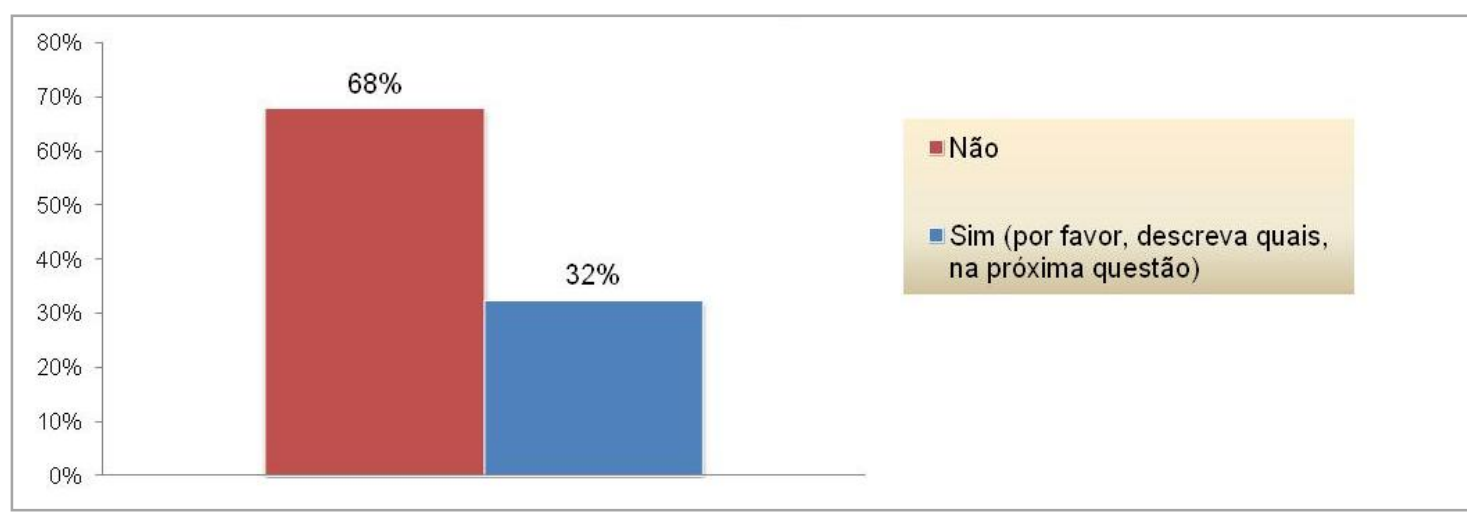

Fonte: elaboração própria.

Ao serem indagados sobre as técnicas e ferramentas de pesquisas mais utilizadas, $10 \%$ dos respondentes declararam usar a busca por verbete e palavras-chave; $10 \%$ usam o campo de busca do portal; e $71 \%$ não descreveram os recursos, provavelmente porque não saberiam denominar os recursos usados ao procurar informação no portal. Os resultados são explicitados na Tabela 3. 
Tabela 3 - Conhecimento de técnicas de pesquisa de informação.

\begin{tabular}{|c|c|}
\hline $\begin{array}{l}\text { Técnicas/ferramentas citadas pelos respondentes como mais } \\
\text { utilizadas ao procurar informação no portal. }\end{array}$ & Em \% \\
\hline Verbetes/palavras- chave & $10 \%$ \\
\hline Campo de busca & $10 \%$ \\
\hline Dados lógicos, como assuntos específicos, títulos, autores & $6 \%$ \\
\hline Banco Achei & $3 \%$ \\
\hline Não descreveram/Não utilizam & $71 \%$ \\
\hline
\end{tabular}

Diante do atual contexto de competitividade e importância da informação nas atividades profissionais, $52 \%$ dos pesquisados indicaram interesse em aprender técnicas e ferramentas que podem auxiliar a pesquisa de informação. Os dados estão representados no Gráfico 20.

Gráfico 20 - Interesse em conhecer técnicas e ferramentas de auxílio em pesquisa de informação.

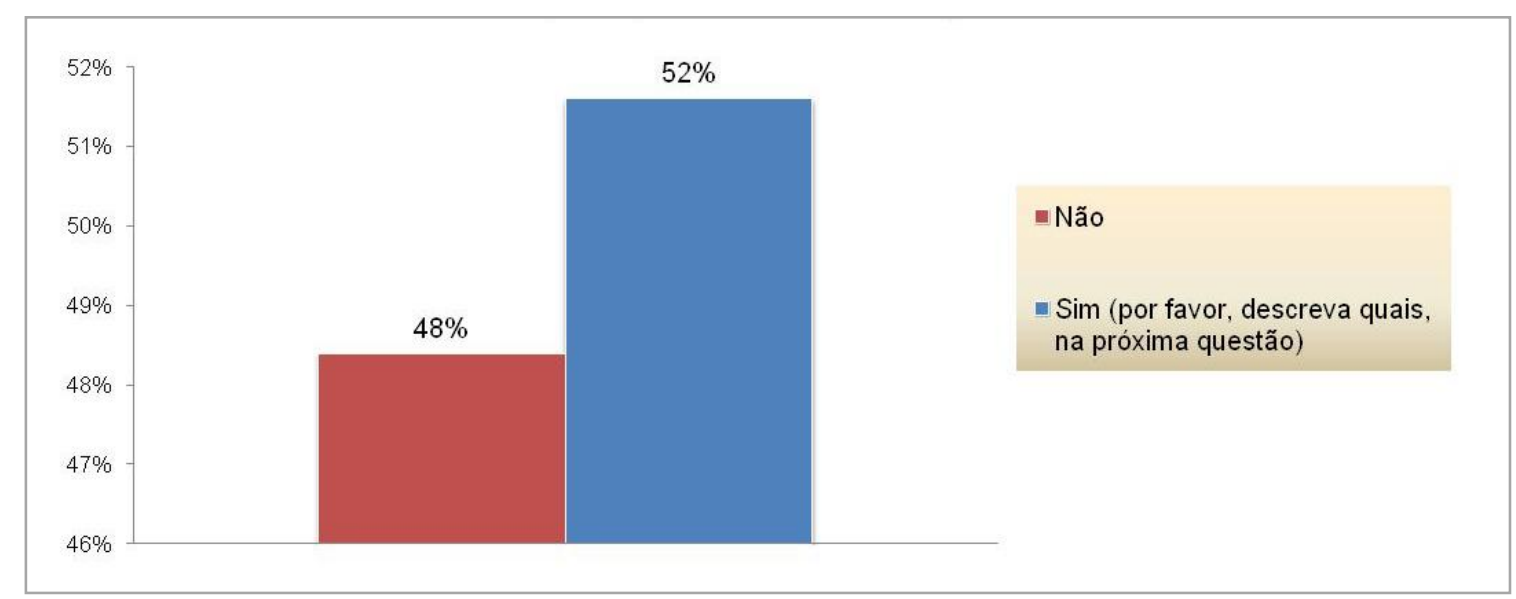

Fonte: elaboração própria.

Pode-se constatar na Tabela 4, que 52\% dos respondentes demonstraram interesse em aprender ferramentas de pesquisa, e a técnica mais citada por $6 \%$ deles, são as relacionadas à busca e pesquisa booleana. Contudo, $84 \%$ dos respondentes não descreveram nenhuma técnica ou ferramenta de pesquisa de informação. 
Tabela 4 - Interesse no aprendizado de técnicas de pesquisa de informação.

\begin{tabular}{lc}
\hline Técnicas/ferramentas tem interesse em aprender. & Em \% \\
\hline Ferramentas livres e técnicas específicas & $3 \%$ \\
\hline Gestão & $3 \%$ \\
\hline Ferramentas de busca /Pesquisa booleana & $6 \%$ \\
\hline Técnicas avançadas de rastreabilidade & $3 \%$ \\
\hline Não descreveram & $84 \%$ \\
\hline \multicolumn{2}{c}{ Fonte: elaboração própria. }
\end{tabular}

Considerações finais sobre Competência Técnica para Realizar Pesquisa da Informação

Os dados provenientes do questionário mostram que mais da metade dos usuários desconhece técnicas de pesquisas. Além disso, afirmaram que não utilizam técnicas que facilitam o processo de busca. Os resultados evidenciaram também que mais da metade dos respondentes têm interesse em conhecer técnicas de pesquisa, embora não saibam especificar as técnicas e/ou ferramentas que tem interesse em aprender.

\subsubsection{Resultados da utilidade da informação para a tomada de decisão e compartilhamento da informação}

O tópico apresenta os resultados sobre a utilidade da informação para a tomada de decisão e o compartilhamento da informação por parte do usuário(a). A ideia é verificar o atendimento da demanda de informação qualificada. Os resultados obtidos são apresentados na mesma sequência presente no questionário.

Ao serem questionados sobre a demanda de informação qualificada, $71 \%$ dos respondentes afirmaram buscar $^{33}$ informação no portal para se informarem sobre ações/decisões já tomadas e $81 \%$ pesquisam para complementar alguma ação/decisão no presente. Os resultados constam no Gráfico 21 e 22.

33 No questionário, evitou-se utilizar o termo técnico pesquisa da informação, atribuído por Wilson (2000) para buscas em sistemas, no intuito de o termo pesquisa não ficar repetitivo para o usuário, que desconhece o conceito e normalmente os considera sinônimos. 
Gráfico 21 - Pesquisa sobre ações/decisões já tomadas (passado).

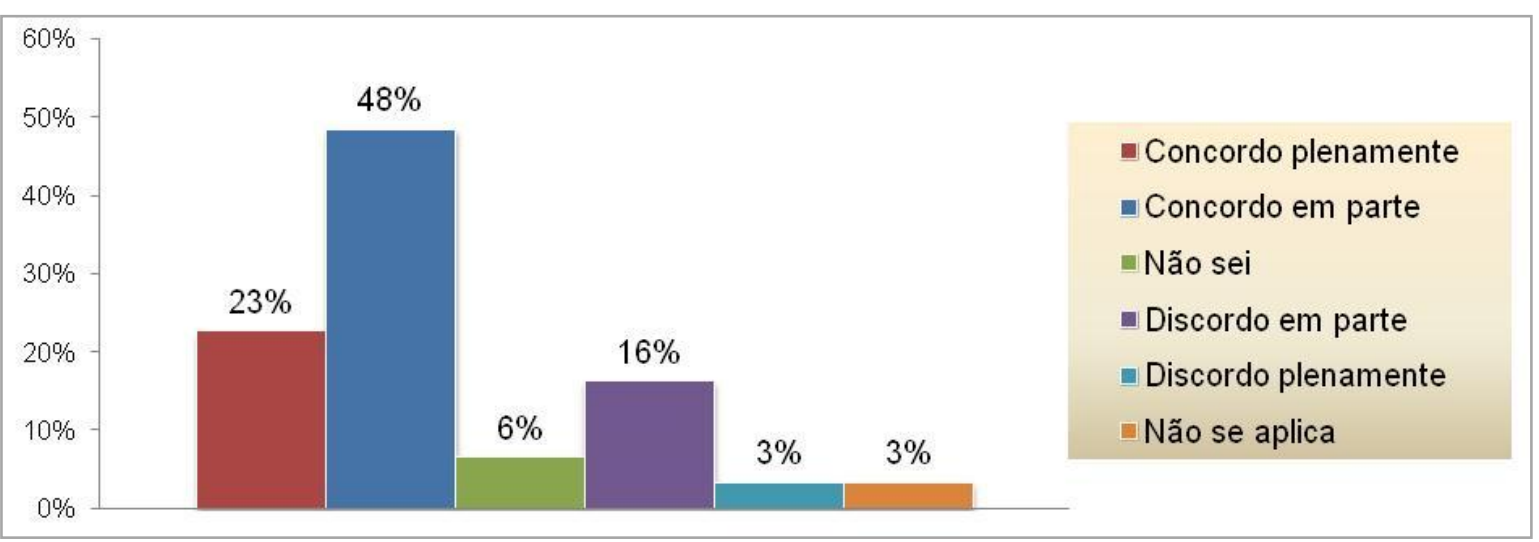

Fonte: elaboração própria.

Gráfico 22 - Pesquisa para complementar ação/decisão atual (presente).

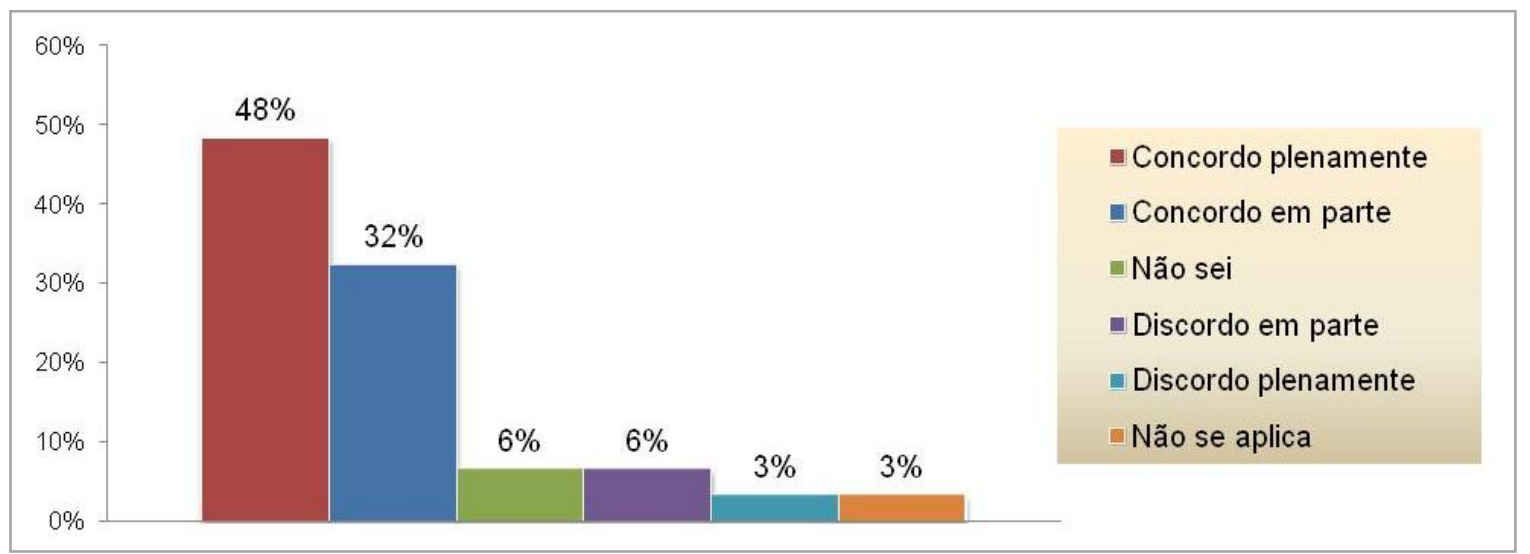

Fonte: elaboração própria.

Ao serem questionados sobre a necessidade de pesquisa para decisão a ser tomada, 87\% respondentes indicaram que consultam o portal para pesquisar informação com intenção de dar suporte a alguma ação/decisão a ser tomada. Dentre os pesquisados, $12 \%$ discordam ou não sabem se utilizam este tipo de pesquisa, como pode-se constatar no Gráfico 23. 
Gráfico 23 - Pesquisa para dar suporte a ação/decisão a ser tomada (futuro).

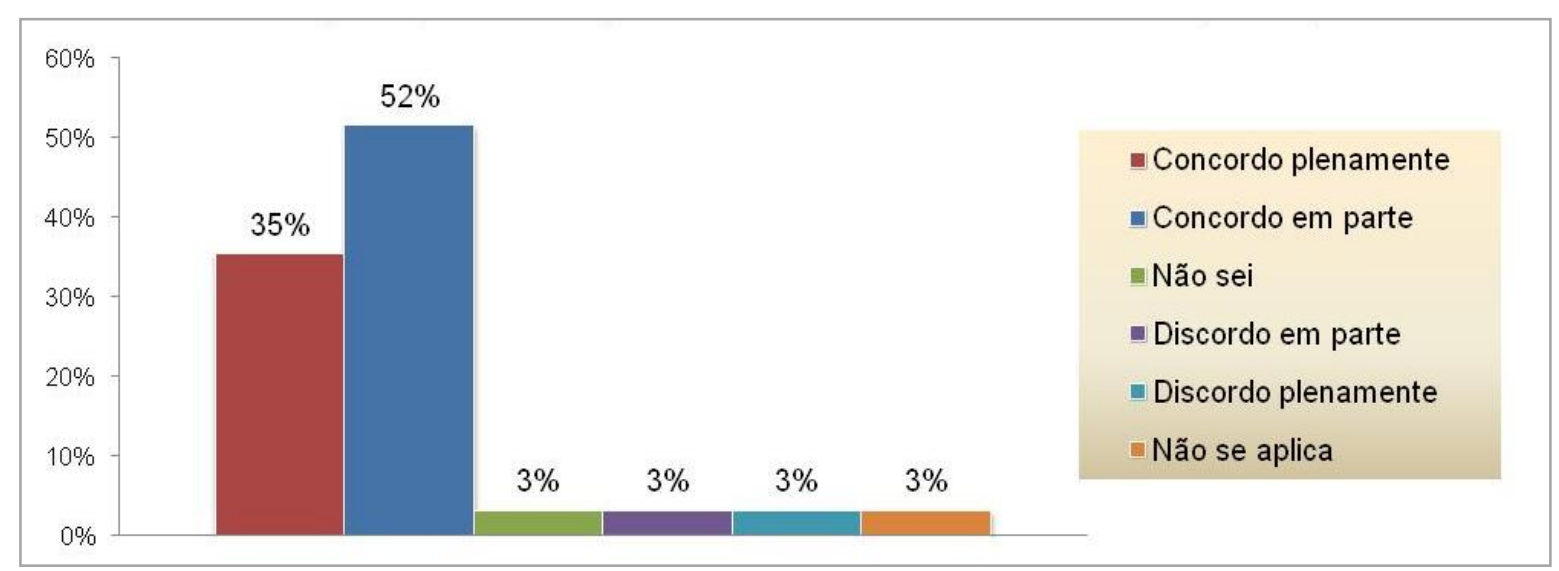

Fonte: elaboração própria.

Em relação à pesquisa sobre conteúdo técnico, $81 \%$ concordam que pesquisam sobre o assunto, por exemplo, estatísticas, dados de mercado, publicações técnicas, etc. e $13 \%$ não usam o portal para consultas de conteúdo técnico. O Gráfico 24 apresenta os resultados.

Gráfico 24 - Pesquisa sobre conteúdo técnico.

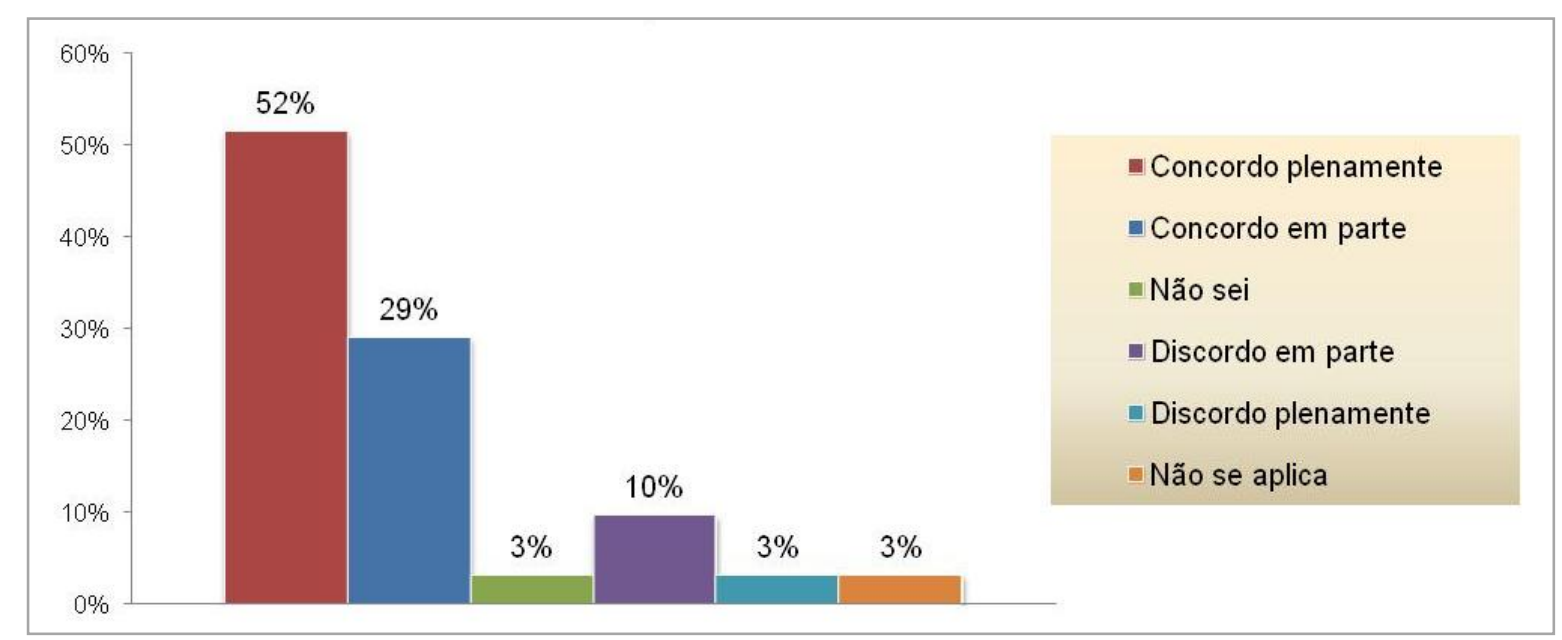

Fonte: elaboração própria.

A atualização sobre produtos e serviços da Eletrobras Eletronorte é preocupação de $81 \%$ dos respondentes. A atualização considerada ocorre mediante de revistas e jornais internos, comunicados e demais informações da organização. Contudo, $16 \%$ responderam que não utilizam o portal com este propósito, como se pode observar no Gráfico 25. 
Gráfico 25 - Pesquisa para atualizar-se sobre produtos e serviços da Eletrobras Eletronorte.

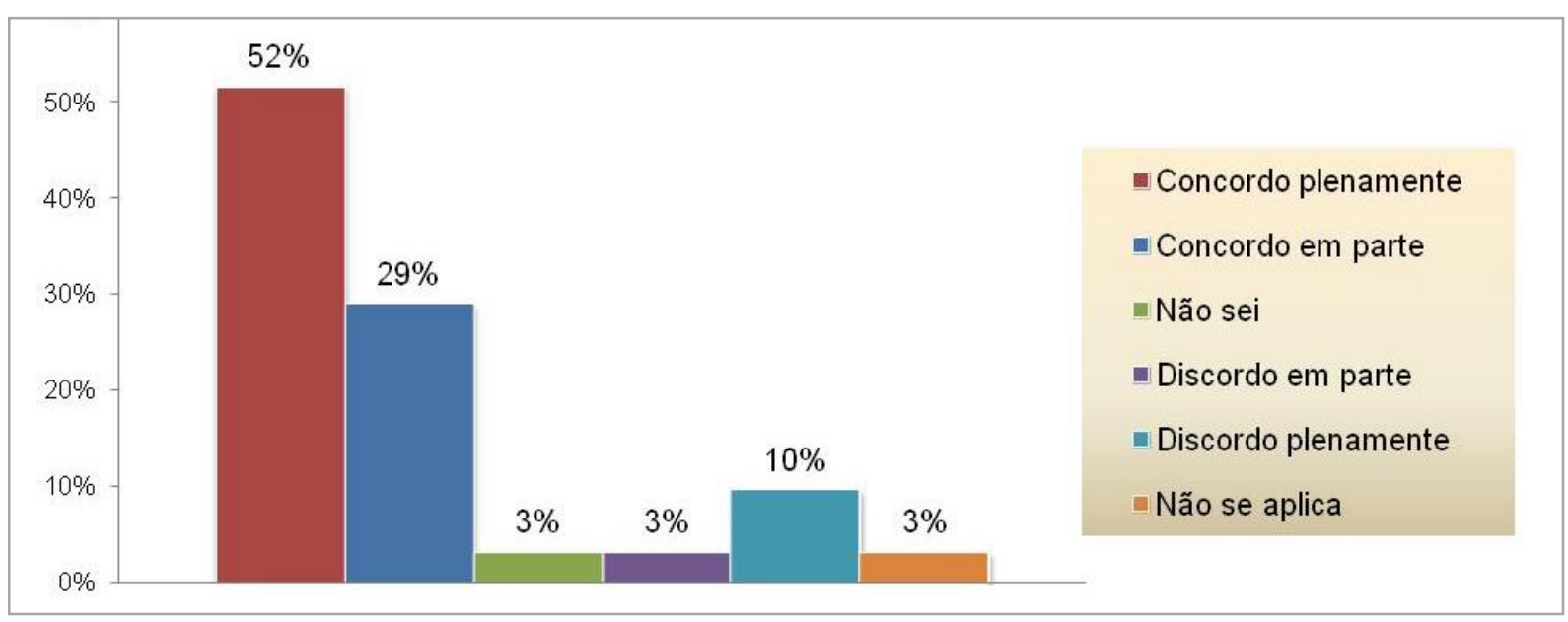

Fonte: elaboração própria.

Em se tratando de atualização sobre o mercado/área de negócios, 65\% dos pesquisados concordam que a fazem, contra $29 \%$ de usuários pesquisados que não utilizam o portal para esta finalidade, conforme demonstrado no Gráfico 26.

Gráfico 26 - Pesquisa para atualizar-se sobre o mercado/área de negócios.

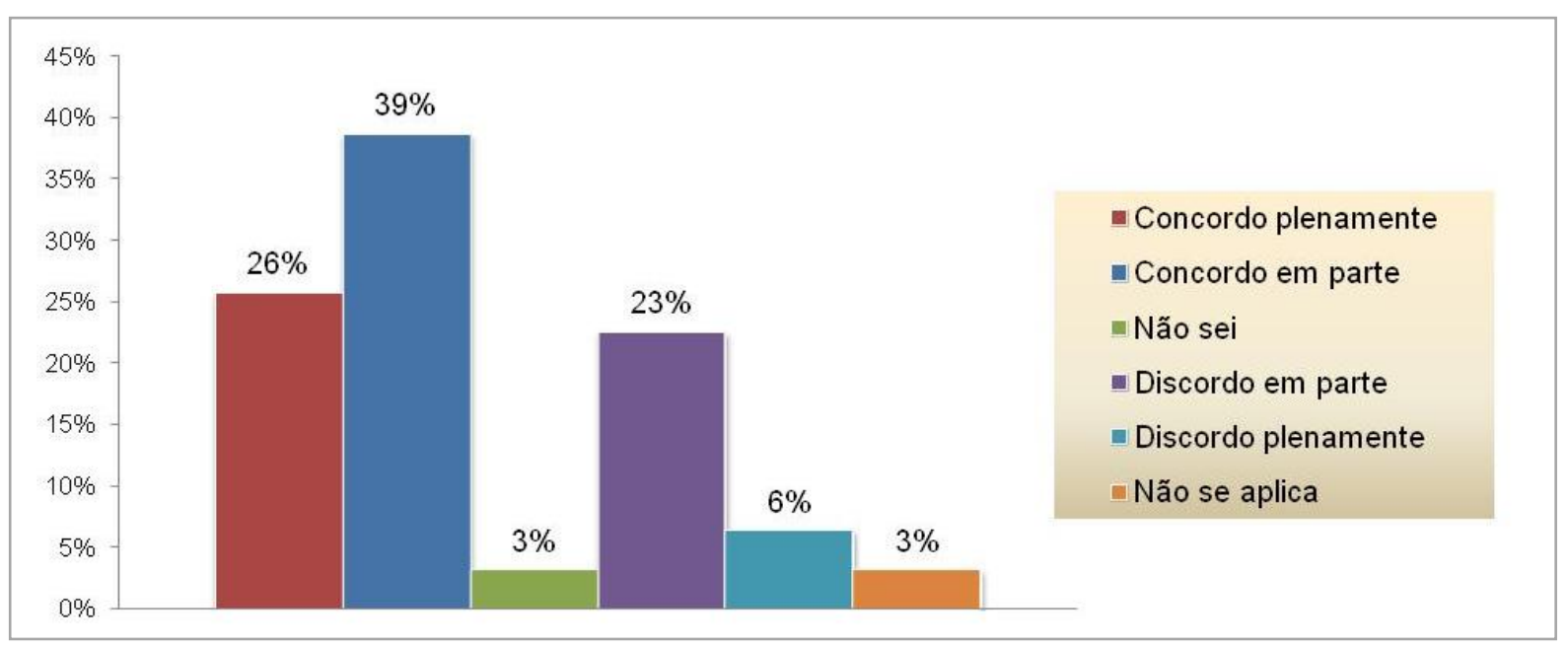

Fonte: elaboração própria.

A pesquisa com objetivo de atualização sobre informações políticas (regulamentações, legislação em geral...) é algo habitual para 74\% dos respondentes. Entretanto, 29\% discordam sobre o uso da pesquisa no portal para a atualização sobre o informações políticas. O Gráfico 27 apresenta os resultados. 
Gráfico 27 - Pesquisa para atualizar-se sobre informações políticas.

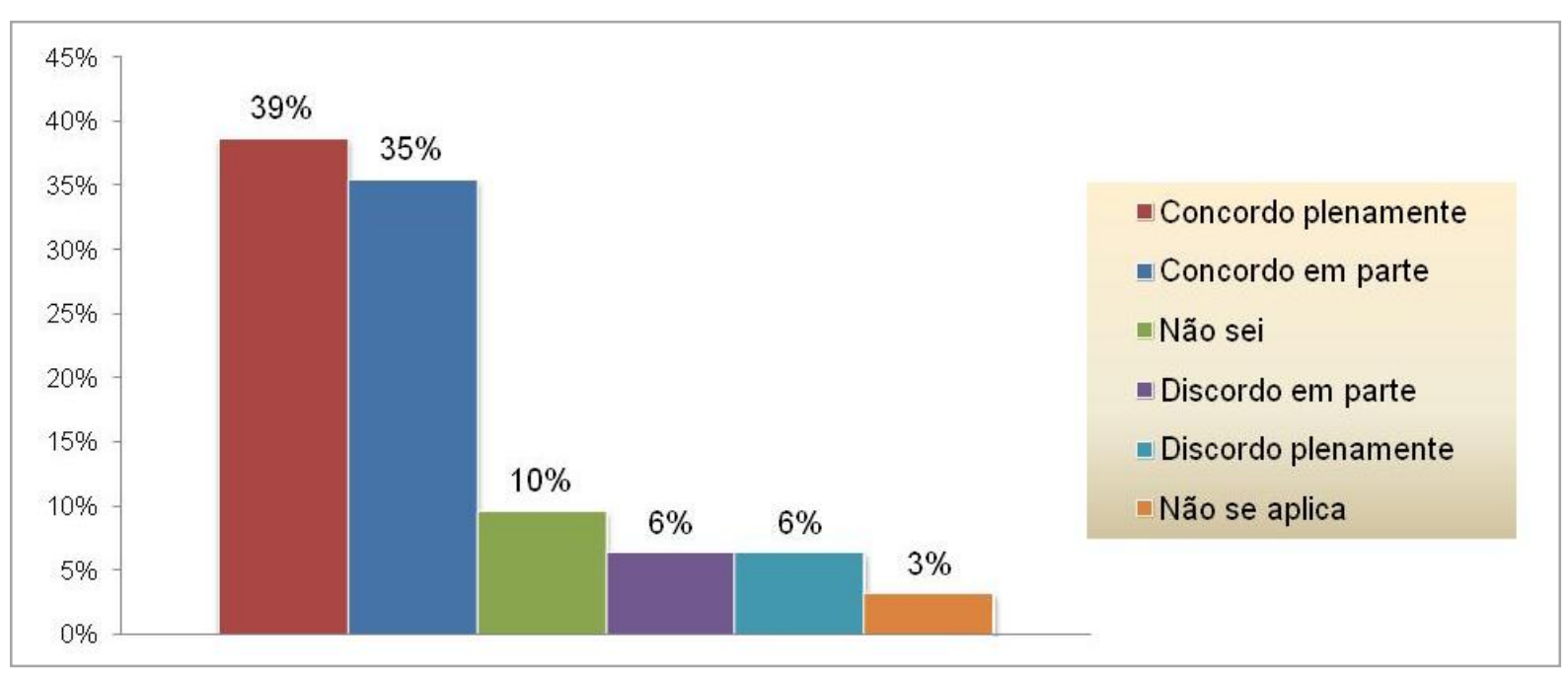

Fonte: elaboração própria.

Os usuários foram questionados sobre o uso do portal para localizar novos talentos e novas parcerias. O Gráfico 28 mostra que $52 \%$ dos pesquisados procuram parcerias para realizar projetos. Outros $29 \%$ discordam do propósito e $10 \%$ afirmaram que não se aplica muito provavelmente como indicativo de que não percebem a utilidade do portal para este fim.

Gráfico 28 - Pesquisa para localizar novos talentos e/ou novas parcerias.

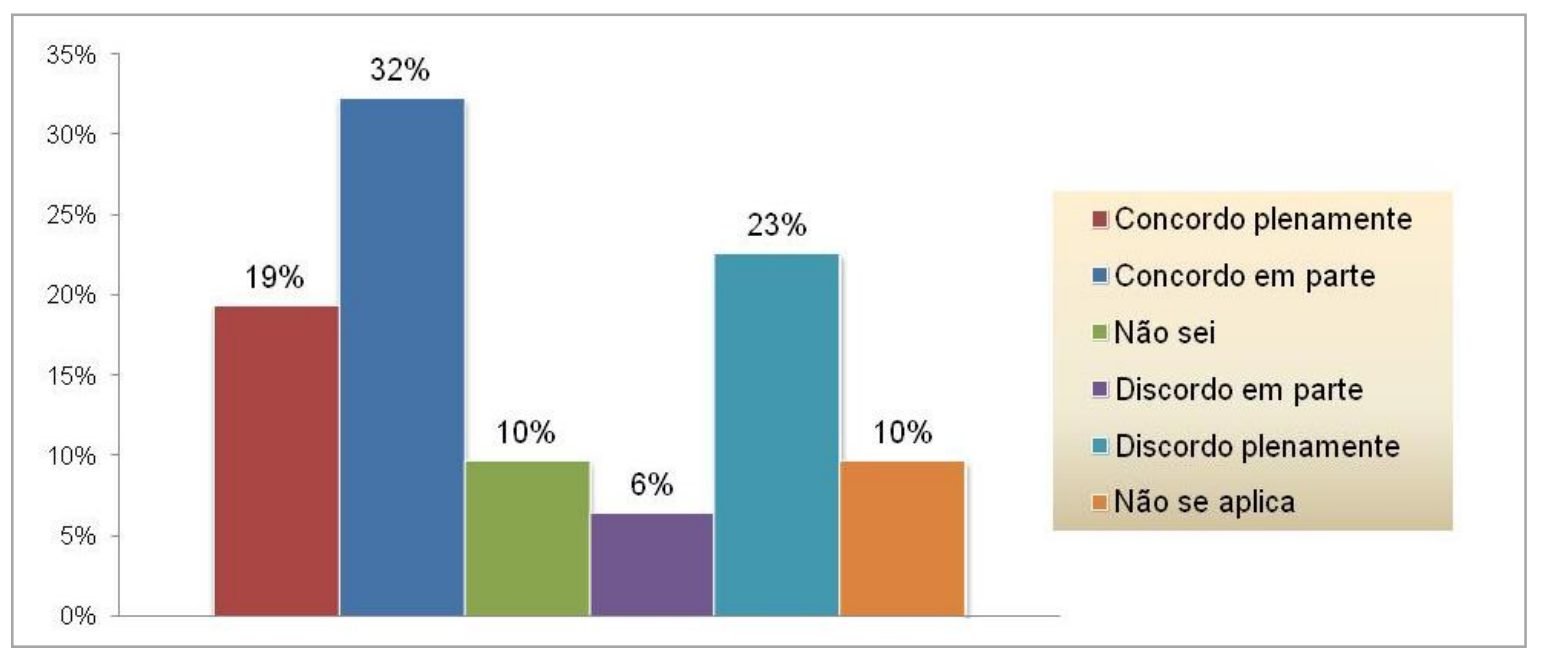

Fonte: elaboração própria.

Considerações finais sobre a utilidade da informação para a tomada de decisão e compartilhamento da informação 
Em relação à utilidade da informação para a tomada de decisão e compartilhamento da informação, pôde-se constatar que a maioria dos pesquisados utiliza o portal para tomar decisão, isto é, para pesquisar a respeito de decisões que já aconteceram, para complementar alguma ação/decisão no presente ou para dar suporte a alguma ação/decisão a ser tomada. Os resultados apontaram também o motivo da busca, em que a maioria realiza pesquisa sobre conteúdo técnico e para se atualizar sobre produtos e serviços da Eletrobras Eletronorte. Mais da metade dos respondentes pesquisa para se atualizar sobre o mercado e a área de negócios, bem como buscam também informações políticas.

Aproximadamente metade dos respondentes apontaram que fazem pesquisa no Portal do Conhecimento com intuito de localizar profissionais e novas parcerias.

\subsubsection{Resultados das opiniões sobre o processo de pesquisa e a natureza da utilização das informações obtidas a partir do portal do conhecimento da Eletrobras Eletronorte}

O tópico trata de questão aberta, sem a delimitação prévia de respostas, em que se pretende explorar a opinião sobre o processo de pesquisa e a natureza da utilização das informações obtidas a partir do portal. Contudo, para efeitos de tabulação, foram agrupadas respostas de conteúdos similares e posteriormente categorizadas. Os resultados estão expressos na Tabela 5.

Tabela 5 - Sugestões/críticas dos respondentes.

\begin{tabular}{lc}
\hline \multicolumn{1}{c}{ Sugestões } & Em \% \\
\hline $\begin{array}{l}\text { Atualização mais eficiente de } \\
\text { informações }\end{array}$ & $6 \%$ \\
\hline Informações dispersas - muitos portais & $3 \%$ \\
Maior divulgação do portal & $6 \%$ \\
Pouco incentivo ao uso do portal & $3 \%$ \\
Maior integração à empresa & $3 \%$ \\
Modernização do layout & $3 \%$ \\
Necessidade de revisões (erros \\
gramaticais)
\end{tabular}

Para melhor compreensão das sugestões e críticas dos pesquisados, são apresentadas contribuições dos respondentes em relação ao objeto de estudo. 
O nosso processo está em constante aperfeiçoamento na organização e, por conta disso, existem algumas dificuldades quanto ao acesso dos empregados ao Portal do Conhecimento. Na minha opinião a organização precisa trabalhar mais e melhor essa questão junto à sua força de trabalho. O portal é um instrumento que pode contribuir significativamente com a manutenção e sobrevivência da empresa no mercado a partir das informações nele contidas. (Profissional de nível superior, sem cargo gerencial)

Os gerentes não utilizam e nem incentivam a utilizar. Não ganhamos nada com isso. O banco achei não serve pra nada, apesar de eu reconhecer que é de extrema importância. O que precisa é de gerentes mais ligados nesses portais, gerando demandas e incentivando as equipes a utilizar. Os gerentes da ELN são muito fracos. (Profissional de nível superior, sem cargo gerencial)

Maior divulgação do Portal. Acredito no potencial e utilidade do mesmo. No entanto em minha área - um dos departamentos de Engenharia - sou o único que o utiliza. Esporadicamente. (Profissional de nível superior, sem cargo gerencial)

O volume de recursos de informações disponibilizados pela empresa, muitas vezes anulam algumas funções do Portal, como é o caso da intranet, que menos estruturada que o portal, também serve como grande ferramenta de busca. (Profissional de nível médio operacional, sem cargo gerencial)

Algumas vezes não consegui acessar os links e outras vezes a informação que vinha era referente a outro assunto, e outras informava que a página não foi encontrada. Manter atualizado os links é importante para o processo do portal do conhecimento. (Profissional de nível médio suporte, sem cargo gerencial)

Atualizar dados e informações, sobretudo referentes às mudanças organizacionais, modernizar layout, experimentar novos formatos, revisar (ou aceitar revisões) e promover correções de erros gramaticais, por exemplo. (Profissional de nível superior, sem cargo gerencial).

A maioria (71\%) dos respondentes não se manifestou sobre quaisquer características do portal. Pode-se deduzir que os respondentes consideraram que as questões anteriores abordaram de forma satisfatória os pontos mais relevantes do objeto de pesquisa; ou que, apesar de suficientes, uma mera questão de desmotivação os impediram de descrever algo.

\subsection{ANÁLISE DE DOCUMENTOS}

Foram realizados levantamentos de dados em diversas fontes de informação que versam sobre a organização, desde a fase do pré-projeto, perpassando o desenvolvimento da pesquisa. As buscas tinham o propósito de atender aos objetivos 1 e 2 especificados para este estudo: levantar dados gerais sobre a empresa e o objeto de pesquisa, e descrever os serviços disponibilizados e os recursos informacionais do portal, respectivamente.

A seleção do Portal do Conhecimento como objeto de pesquisa foi feita a partir de visita de reconhecimento à Universidade Corporativa da Eletrobras Eletronorte (UCEL) no intuito de conhecer sua infraestrutura, então foco da pesquisa. Na ocasião, foram apresentadas 
as plataformas que integram a UCEL, dentre elas o portal, bem como informativos internos que abordavam a importância da ferramenta para a empresa, que amparou a justificativa do estudo. Corroborando com a proposta, foram realizadas consultas a sítios de entidades que promoveram premiação recebida pela Eletrobras Eletronorte (Anexo C).

As consultas ao sítio da Eletrobras Eletronorte e ao próprio Portal do Conhecimento tornaram possível a identificação de características importantes da empresa e do objeto de estudo selecionado. A ideia foi identificar a pertinência ao contexto científico, a fim de amparar o estudo nos moldes do PPGCInf. Para tanto, foram consultadas outras fontes, tais como livros, artigos e periódicos da área da Ciência da Informação, que proporcionaram suporte à formulação do problema da pesquisa, uma vez que se identificou parte das questões a serem abordadas no estudo e integraram a revisão de literatura. Posteriormente, consultas realizadas a documentos internos e dados fornecidos pelos gestores auxiliaram na definição da população e da composição da amostra para a realização da pesquisa.

Os materiais mais relevantes integram a seção de anexos do presente trabalho.

\subsection{ENTREVISTA COM GESTORES}

Parte dos objetivos específicos propostos no estudo foram atingidos devido a intervenção - direta e indiretamente - dos gestores do Portal do Conhecimento da Eletrobras Eletronorte, área que, no início do trabalho, estava sob supervisão da Gerência de Gestão do Conhecimento (GSEC). Após passarem por reestruturação interna (segundo trimestre de 2013), as áreas de gestão do conhecimento e educação corporativa foram unificadas, tendo originado a Assessoria de Educação e Conhecimento (GAE), atual responsável pelo portal.

Foram realizadas duas reuniões com os gestores, uma no início da pesquisa propriamente dita (agosto/2012) e outra por ocasião da coleta de dados (agosto/2013). A compilação dos principais pontos tratados consta nos anexos (Apêndices A e B).

Com o objetivo de apoiar a discussão dos resultados, alguns itens provenientes dos contatos com os gestores foram categorizados e disponibilizados na Tabela 6. 
Quadro 8 - Contribuição dos gestores do portal do conhecimento para a pesquisa.

\begin{tabular}{|c|c|}
\hline Funcionalidade & Circunstância/ação \\
\hline $\begin{array}{l}\text { Acesso a } \\
\text { informações }\end{array}$ & $\begin{array}{l}\text { Até agosto/2012 houve pouco mais de } 42.200 \text { acessos (desde 10/2010). Um número } \\
\text { relevante para um portal ainda pouco conhecido na organização. } \\
\text { O acervo digital não está completo. Ainda há documentos importantes que não foram } \\
\text { digitalizados. } \\
\text { Há diversos portais na empresa e não estão devidamente integrados. Trata-se de algo } \\
\text { como uma "sopa de portais", que confunde e dissipa os esforços de gestão de } \\
\text { informações. } \\
\text { Na Eletronorte, a intranet ainda é um dos principais canais de comunicação com o } \\
\text { público interno. } \\
\text { O portal corporativo está alinhado com as diretrizes do planejamento estratégico e é uma } \\
\text { ferramenta importante de integração e mobilização dos colaboradores, mas o acesso não é } \\
\text { está muito visível na intranet. } \\
\text { Nem todos da organização podem/necessitam acessar o portal. Um exemplo é a Norte } \\
\text { Energia }{ }^{34} \text {, que abriga mais de } 25 \text { mil trabalhadores (entre mão de obra direta e indireta) o } \\
\text { que representa um grande impacto na economia local. O motivo parece ser o fato de que } \\
\text { muita gente apaga e-mails sem ler; não têm hábito de buscar informação. } \\
\text { Há uma grande diversidade de canais de comunicação, o que o faz "filtrar" as } \\
\text { informações necessárias por canais. Isso muda quando há uma necessidade de informação } \\
\text { específica. }\end{array}$ \\
\hline $\begin{array}{l}\text { Compart } \\
\text { o de infor }\end{array}$ & $\begin{array}{l}\text { O Programa de Identificação e Compartilhamento do Conhecimento Crítico (PICC) visa } \\
\text { identificar a disseminação do conhecimento conforme demandas do usuário. A ideia é } \\
\text { converter o conhecimento tácito existente (das pessoas que trabalham na empresa) e } \\
\text { sistematizá-los. Desta forma, transformam-se em conhecimento institucional passível de } \\
\text { ser compartilhado. } \\
\text { Há muitas "ilhas de excelência" na organização, é preciso trabalhar a ideia de } \\
\text { compartilhamento. } \\
\text { Em casos de cursos ou eventos gerenciais, há pouca frequência. Colaboradores parecem } \\
\text { motivados a participarem quando há sorteio de brindes, lanche ou algo similar. } \\
\text { Há políticas que versam sobre o fornecimento de material para o acervo: uma cópia deve } \\
\text { ser fornecida para o acervo de qualquer produto/trabalho sobre a empresa. Há a } \\
\text { obrigatoriedade quando o colaborador tem seu curso patrocinado pela organização. } \\
\text { O Portal de Colaboração "SharePoint" é uma plataforma incentiva a interação entre } \\
\text { usuários, na parte de acesso restrito do Portal Eletronorte, porém ainda não está } \\
\text { amadurecida. }\end{array}$ \\
\hline Divulgação & $\begin{array}{l}\text { Boa parte da divulgação vem do boca a boca, há divulgação a respeito de um ou outro } \\
\text { material específico, o que aumenta a demanda para aquele produto. } \\
\text { Aconteceram diversos esforços para promover o portal em eventos gerenciais e } \\
\text { institucionais, o que colaborou, mas não "decolou". } \\
\text { Os gestores julgam que haveria grande incremento na divulgação caso os acessos à } \\
\text { UCEL e à Intranet fossem a partir do Portal do Conhecimento. } \\
\text { Há dificuldades na divulgação - parece haver cultura disseminada na organização de não } \\
\text { ler e-mails (salvo de remetentes pré-definidos). Os demais são apagados sem que haja } \\
\text { leitura prévia, sequer de banners dinâmicos ou pop-ups utilizados no sítio da empresa. } \\
\text { É urgente a necessidade de promoção da unidade de informação Portal do Conhecimento } \\
\text { para tentaram ampliar o interesse/demanda, pois há empregados que ainda não conhecem } \\
\text { o portal, ou não tem ideia do seu conteúdo. }\end{array}$ \\
\hline
\end{tabular}

Continua.

34 A Norte Energia é uma Sociedade de Proposta Específica (STE), como são denominadas a parceira públicoprivada formada a cada novo empreendimento/consórcio. Nesse caso, é a gestora da Usina de Belo Monte. 
Conclusão.

\begin{tabular}{|c|c|}
\hline Funcionalidade & Circunstância/ação \\
\hline \multirow{3}{*}{$\begin{array}{l}\text { Gestão do } \\
\text { conteúdo }\end{array}$} & Na Eletronorte a gestão do conteúdo fica a cargo da GSEC (hoje, GAE). \\
\hline & $\begin{array}{l}\text { O lugar onde o usuário informa suas demandas é o "fale conosco" - contato direto (por } \\
\text { telefone ou email), com a área responsável pela demanda. }\end{array}$ \\
\hline & $\begin{array}{l}\text { A área de comunicação gerencia o conteúdo da intranet e internet. Há diversas "ilhas de } \\
\text { excelência", cada qual com sua ideia de portal. }\end{array}$ \\
\hline \multirow[t]{2}{*}{$\begin{array}{l}\text { Conteúdos mais } \\
\text { acessados }\end{array}$} & $\begin{array}{l}\text { Levantamento recente do webmaster apontou, em ordem de acessos: } 1 \text {.Acervo Online; } \\
\text { 2.Normas Técnicas; 3.PICC; 4.SECI; 5.BMDT. }\end{array}$ \\
\hline & $\begin{array}{l}\text { Estatísticas fornecidas pelo webmaster em agosto de } 2012 \text { (que colaboraram com o } \\
\text { cálculo da amostra) apontavam } 283 \text { acessos no mês e os conteúdos mais acessados foram: } \\
\text { 1.Acervo Online; 2.Normas Técnicas; 3.Banco de Inovação; 4.Painel Interno de Melhoria } \\
\text { (PIM). }\end{array}$ \\
\hline
\end{tabular}

Fonte: elaboração própria.

Pôde-se constatar que os gestores têm conhecimento dos pontos que podem ser melhorados no portal, porém alguns dependem de ações e esforços de outras áreas, notadamente de alterações em diretrizes da organização, passíveis de análise dos dirigentes que atuam em nível estratégico. Por outro lado, diversas mudanças foram realizadas no portal no intuito de melhorar a usabilidade, ou seja, a capacidade do portal ser usado com eficiência e eficácia por determinados usuários para atingir objetivos pré-definidos de maneira satisfatória (DIAS, 2001b). 
O tópico apresenta a discussão dos resultados obtidos no estudo, provenientes dos diversos instrumentos de coleta de dados - pesquisa documental, entrevista semiestruturada e questionário - que foram relacionados com as teorias abordadas na revisão de literatura e a compreensão da pesquisadora sobre o objeto analisado. A discussão encontra-se em conformidade com a técnica específica de análise de evidências proposta por Calazans (2007) - a construção da explanação - em que as análises dos dados objetivam construir uma explanação sobre o caso estudado. A proposta é contribuir para o desenvolvimento do conhecimento do tema pesquisado, associando os resultados à fundamentação teórica apresentada, no intuito de proporcionar resposta(s) à questão central do trabalho compreender a relação entre o uso do portal corporativo e a tomada de decisão.

Para tanto, definiu-se como objetivo principal do estudo, investigar o comportamento de pesquisa da informação de usuários de portal corporativo para a tomada de decisão. Para fins de composição da pesquisa, o objetivo geral foi desdobrado em quatro objetivos específicos, os quais são apresentados com os principais aspectos observados na coleta de dados.

\subsection{LEVANTAR DADOS GERAIS SOBRE A EMPRESA E O OBJETO DE PESQUISA.}

Compreender a relação entre uso de portal corporativo e a tomada de decisão torna-se importante na sociedade contemporânea, em especial por possibilitar maior produtividade e competitividade. Para empreender tal estudo, realizou-se estudo de caso na Eletrobras Eletronorte, por apresentar a complexidade necessária para validação do experimento, por envolver usuários em diferentes situações profissionais, com diversidade de formação acadêmica e demandas específicas, fator de enriquecimento do estudo. Informações detalhadas sobre a empresa foram apresentadas no capítulo dois do estudo. Portanto, são apresentados aspectos gerais da empresa no tópico.

Os dados levantados pela entrevista semiestruturada e análise documental foram essenciais na definição da população e da composição da amostra para este trabalho, além de apontar indícios pertinentes aos demais itens avaliados. A contribuição dos gestores do portal foi fundamental, uma vez que conhecem bem o objeto de pesquisa.

Nas investigações feitas em diversos documentos, nota-se que a Eletrobras Eletronorte realiza diversos esforços para desenvolver o conhecimento organizacional, incluindo 
programas e sistemas para incentivar o emprego eficaz da informação e gerar valor agregado aos produtos e serviços da organização (CHOO, 2006). Tal empenho visa a obtenção de vantagem competitiva, fato intrínseco no planejamento estratégico (YANAZE, 2006). Em 2020, a Eletrobras Eletronorte pretende ser "o maior sistema empresarial global de energia limpa, com rentabilidade comparável às das melhores empresas do setor elétrico" 35 (ELETRONORTE, 2012, p. 18). Para atingir tal objetivo, busca implementar a missão de "atuar nos mercados de energia de forma integrada, rentável e sustentável" 36, e trabalhar com profissionais que compartilham os valores, tais como "foco em resultados, empreendedorismo e inovação, valorização e comprometimento das pessoas, ética e transparência" ${ }^{37}$.

Para cumprir a proposta, a empresa precisa de profissionais capazes de interpretar e gerenciar informações qualificadas, de formas a tomar decisões de forma eficaz e eficiente (AMARAL, 2007). Dispor de informações qualificadas em cada fase do processo de tomada de decisão é um fator essencial para gerar resultados positivos no ambiente organizacional (CASSARRO, 2003). Para tanto, utiliza o Portal do Conhecimento como uma das ferramentas no auxílio da gestão do conhecimento, por viabilizar a categorização, localização, compartilhamento e gerenciamento da informação, além de ofertar programas específicos para incentivar colaboradores e parceiros no desenvolvimento, armazenamento e transferência de conhecimentos com objetivo de inovação, constantemente, para atender ao exigente mercado em que atua (SGUARIO; TOMAÉL, 2011).

\subsection{IDENTIFICAR OS SERVIÇOS DISPONIBILIZADOS E OS RECURSOS INFORMACIONAIS DO PORTAL DO CONHECIMENTO DA ELETROBRAS ELETRONORTE}

Para identificar os serviços e recursos do portal analisou-se o próprio Portal do Conhecimento, além de consultas em outras fontes da empresa, por exemplo, o Informativo Novo Tempo (Ed. 21/10/2010) e opinião dos gestores do portal. As questões mais relevantes são descritas no Quadro 8.

\footnotetext{
35 Visão da Eletrobras Eletronorte, disponível no Relatório de Sustentabilidade 2012, p. 12.

${ }^{36}$ Missão da empresa, Op. Cit.

37 Valores da organização, Op. Cit.
} 
Quadro 9 - Funcionalidades básicas do portal do conhecimento Eletrobras Eletronorte.

\begin{tabular}{|c|c|}
\hline Funcionalidade & Ação \\
\hline $\begin{array}{l}\text { Acervo da Biblioteca Raul } \\
\text { Garcia Llano }\end{array}$ & $\begin{array}{l}\text { Acesso ao sistema Sophia, permite o compartilhamento das informações técnicas } \\
\text { atualizadas e necessárias ao desempenho das atividades corporativas. }\end{array}$ \\
\hline $\begin{array}{l}\text { Anais de congressos e } \\
\text { seminários }\end{array}$ & $\begin{array}{l}\text { Apresenta artigos e trabalhos apresentados em eventos externos e internos, em } \\
\text { diversas áreas de conhecimento e de interesse da Eletrobras Eletronorte. }\end{array}$ \\
\hline Banco de inovação & $\begin{array}{l}\text { Possui produtos gerados por meio de P\&D, Painel Integrado da Qualidade - PIQ, } \\
\text { Prêmio Muiraquitã, ISO, TPM e demais fóruns de inovações, soluções e } \\
\text { melhorias, para gerir e dar suporte ao processo de validação, aplicação, } \\
\text { replicação, transferência de tecnologia e proteção dos produtos. }\end{array}$ \\
\hline $\begin{array}{l}\text { Produtos de pesquisa e } \\
\text { desenvolvimento }\end{array}$ & $\begin{array}{l}\text { Orientações para acesso ao banco e utilização da Guia de Solicitação e } \\
\text { divulgação de produtos gerados na Eletrobras Eletronorte (P\&D). }\end{array}$ \\
\hline Banco Achei & $\begin{array}{l}\text { Banco de currículos eletrônicos, o Achei tem o objetivo de indicar pessoas, ou } \\
\text { seja, promover a identificação e a localização rápida de especialistas nas áreas de } \\
\text { geração, transmissão e telecom. }\end{array}$ \\
\hline $\begin{array}{l}\text { BMDT - Banco de } \\
\text { monografias, dissertações e } \\
\text { teses dos empregados }\end{array}$ & $\begin{array}{l}\text { Disponibiliza produtos acadêmicos voltados ao negócio da Empresa, elaborados } \\
\text { por autor ou coautor com vínculos profissionais com a Eletrobras Eletronorte, } \\
\text { bem como aqueles patrocinados pela Universidade Corporativa Eletronorte } \\
\text { (UCEL). }\end{array}$ \\
\hline $\begin{array}{l}\text { Sistema eletrônico de } \\
\text { normas técnicas via web }\end{array}$ & $\begin{array}{l}\text { Coleção de normas digitais que apoiam os processos produtivos - são mais de } \\
800 \text { normas técnicas nacionais e internacionais que podem ser baixadas ou } \\
\text { impressas. }\end{array}$ \\
\hline Produtos IEEE & $\begin{array}{l}\text { Pacote de documentos do IEEE (Institute of Electrical and Electronics } \\
\text { Engineers), cujo portal, o IEEE Xplore, funciona como biblioteca digital com } \\
\text { acesso a conteúdos científicos e técnicos publicados pelo instituto, inclusive para } \\
\text { download. São } 149 \text { jornais, mais de } 950 \text { conferências e mais de dois milhões de } \\
\text { documentos. }\end{array}$ \\
\hline $\begin{array}{l}\text { Produtos do Painel Integrado } \\
\text { da Qualidade - PIQ }\end{array}$ & $\begin{array}{l}\text { Aborda trabalhos apresentados nas quatro últimas edições do PIQ, principal } \\
\text { evento de compartilhamento de resultados das ações criativas, inovadoras e } \\
\text { empreendedoras, dos empregados da Eletronorte, também conhecido como o } \\
\text { Oscar da Eletronorte. }\end{array}$ \\
\hline PICC & $\begin{array}{l}\text { Acesso ao Programa de Identificação e Compartilhamento do Conhecimento } \\
\text { Crítico - PICC. }\end{array}$ \\
\hline $\begin{array}{l}\text { Acesso a outros portais da } \\
\text { Eletrobras Eletronorte }\end{array}$ & $\begin{array}{l}\text { A partir do Portal do Conhecimento, o usuário possui acesso a outros portais } \\
\text { corporativos da organização: Portal de Gestão estratégica; Portal Educação } \\
\text { Corporativa; Portal de Colaboração Share Point; Portal SPE's e PLM Portal } \\
\text { (acesso interno), além da intranet. }\end{array}$ \\
\hline Documentos corporativos & $\begin{array}{l}\text { Direcionado à intranet, o link dá acesso a documentos sobre a organização, tais } \\
\text { como informativos, manuais, planejamento estratégico, dentre outros. }\end{array}$ \\
\hline Comunidades virtuais & $\begin{array}{l}\text { Acesso comunidades virtuais: Inovação Tecnológica na Eletrobras Eletronorte; } \\
\text { Programa de Identificação do Conhecimento Crítico; Programa FOCUS - todos } \\
\text { direcionados ao ambiente virtual da UCEL. }\end{array}$ \\
\hline Links de interesse & $\begin{array}{l}\text { Listagem de acessos a sítios de empresas e demais entidades relacionados à } \\
\text { Eletronorte e outras empresas de energia elétrica, bem como links de instituições } \\
\text { e empresas relacionados ao meio ambiente. }\end{array}$ \\
\hline Periódicos da empresa & $\begin{array}{l}\text { Redireciona o usuário ao sítio da empresa, na seção do acesso a exemplares } \\
\text { digitalizados da Revista Corrente Contínua e Jornal Novo Tempo. }\end{array}$ \\
\hline
\end{tabular}

Continua. 
Conclusão.

\begin{tabular}{|c|c|}
\hline Funcionalidade & Ação \\
\hline Eventos internos & $\begin{array}{l}\text { Acesso a informações sobre eventos realizados pela empresa: } \\
\text { - Semana Nacional de Proteção de Energia Elétrica (anos ímpares) } \\
\text { - SECI - Semana Eletronorte do Conhecimento e Inovação: fórum de } \\
\text { disseminação do conhecimento da organização com gestores do } \\
\text { conhecimento. São } 4 / 5 \text { ambientes simultâneos de atividades. } \\
\text { - PIMs - Painéis Internos de Melhoria: evento para seleção preliminar dos } \\
\text { melhores trabalhos da unidade, encaminhados depois ao PIQ. } \\
\text { - PIQ - Painel Integrado de Qualidade: expõe os trabalhos aprovados nos } \\
\text { PIMs, que integram o Banco (de Ideias) do Conhecimento. } \\
\text { - Prêmio Muiraquitã: reconhecimento das inovações oriundas dos } \\
\text { colaboradores e departamentos de P\&D. } \\
\text { - Comitê de especialistas: comitê de implantação da cadeia de inovação } \\
\text { tecnológica (CICIT) - identificação de demandas e colaboração na } \\
\text { disseminação do conhecimento. }\end{array}$ \\
\hline Ferramenta de busca & $\begin{array}{l}\text { Importante funcionalidade para a pesquisa da informação, a máquina de busca } \\
\text { deve oferecer recursos para refinar e filtrar informações, dentre outros. Apesar da } \\
\text { posição de destaque no portal (no menu vertical, no canto esquerdo do sítio), } \\
\text { parece não estar em pleno funcionamento, ao menos para usuário externo ao } \\
\text { ambiente corporativo (sem login). }\end{array}$ \\
\hline
\end{tabular}

Fonte: Portal do conhecimento Eletrobras Eletronorte e informativo Novo Tempo ( 21/10/2010).

Conforme Dias (2001b), oferecer suporte à decisão e processamento cooperativo são algumas das funções mais importantes de um portal corporativo. Verifica-se que o Portal do Conhecimento disponibiliza acesso a diversos documentos - internos e externos - essenciais ao desempenho dos profissionais da Eletrobras Eletronorte, incluindo acesso ao acervo da biblioteca da organização, com livros, periódicos, trabalhos acadêmicos e legislação do setor. Parte deste material encontra-se digitalizado, o que favorece ao atendimento remoto (SALDANHA, 2012), ponto importante para a empresa, cuja atuação abrange enorme área geográfica. Contudo, outra parte existe apenas na forma impressa, disponibilizada na sede, mais especificamente na Biblioteca Raul Garcia Llano. Apesar disso, o portal disponibiliza sistema de consultas e empréstimos que atende ao usuário local ou das regionais, e o material pode ser enviado posteriormente.

Pode-se notar que há divulgação de programas e eventos internos de incentivo à inovação e gestão do conhecimento, além de links diretos para outras áreas de interesse do profissional, desde portais internos a sítios de outras organizações (MORESI; MENDES, 2010). Todavia, é curioso obervar que o estudo aponta pouco interesse dos respondentes em questões do mercado e área de negócios, apesar de ser relevante para os profissionais monitorar os ambientes de negócio (CHOO, 2006). Isto pode ocorrer em virtude do portal não apresentar conteúdo relacionado com essa especificidade. Pressupõe-se que os empregados 
devem recorrer a outras fontes, tais como portais relacionados às áreas de economia e mercado, jornais e revistas de negócios. Esta situação pode ser interpretada como uma oportunidade para o portal ampliar seus serviços e, muito provavelmente, aumentar o número de acessos e usuários.

\subsection{IDENTIFICAR O PERFIL DOS USUÁRIOS DO PORTAL DO CONHECIMENTO ELETROBRAS ELETRONORTE}

Identificar as principais características dos respondentes é fator importante para estudos de comportamento informacional, uma vez que o processo da busca de informação começa a partir do reconhecimento de alguma necessidade percebida pelo usuário (WILSON, 1981). Martinez-Silveira e Oddone (2007) demonstraram que as variáveis que interagem na decisão da busca da informação são basicamente de origem psicológica (simples curiosidade ou necessidade de conhecer) e demográfica (indivíduos relativamente jovens, estudantes; ou relacionadas com a função, por exemplo).

A maioria dos participantes da pesquisa ocupa cargos de nível superior, fato esperado haja vista a característica do setor, que valoriza a aquisição de conhecimentos como meio de aderência ao Modelo Atual do Setor Elétrico. "Compreender a legislação vigente, as estratégias de expansão e as possibilidades de novos empreendimentos é essencial para a manutenção da competitividade da Eletronorte no setor elétrico" (ELETRONORTE) ${ }^{38}$. Mais que isso, quase a totalidade dos respondentes possui formação acadêmica no ensino superior, incluindo cursos de pós-graduação em nível de especialização, mestrado e doutorado. Outro ponto a considerar é que nenhum dos respondentes tem menos de um ano na empresa, 64\% deles estão há mais de 16 anos na corporação, pode-se concluir que conhecem bem a realidade da Eletrobras Eletronorte, dado que pode ser considerado como um indicador de qualidade da amostra.

Do ponto de vista de faixa etária e gênero, a maioria do público pesquisado é composto por profissionais em idade madura (acima dos 46 anos) e representantes do gênero masculino, apesar da participação feminina ser considerável, em se tratando que a área de engenharia é tradicionalmente ocupada por homens.

\footnotetext{
38 A Cartilha Modelo Atual do Setor Elétrico, produzida pela Eletronorte, apresenta os conceitos e alterações na legislação do Setor Elétrico para os seus profissionais. O Modelo Atual do Setor Elétrico foi estabelecido pelas Leis Federais $\mathrm{n}^{\circ} 10.847$ e nº 10.848, de março 2004, e regulamentado pelos Decretos $\mathrm{n}^{\circ} 5.163, \mathrm{n}^{\circ} 5.175$ e n ${ }^{\circ} 5.184$.
} 
Ao se considerar também a formação acadêmica, pode-se inferir que a empresa possui profissionais experientes, qualificados para enfrentarem os desafios profissionais. A Política de Gestão de Pessoas do Sistema Eletrobras (instaurada em 05/2012) ${ }^{39}$ estabelece diretrizes quanto aos profissionais capazes de se adequarem ao modelo de carreira com foco em competência e resultados. O Plano de Carreira e Remuneração (PCR) da empresa estrutura-se nas dimensões carreira, cargos, remuneração e desempenho ${ }^{40}$, o que parece justificar o interesse do empregado em buscar capacitação acadêmica e profissional. A empresa incentiva o desenvolvimento do conhecimento organizacional e a inovação pela implantação de programas e criação de áreas específicas, haja vista a recente estruturação que originou a Assessoria de Educação e Conhecimento (GAE), atual área responsável pelo portal, resultante da unificação da área de Gerência de Gestão do Conhecimento e da Universidade Corporativa.

\subsection{MAPEAR OS PADRÕES DE COMPORTAMENTO DE PESQUISA DA INFORMAÇÃO DOS USUÁRIOS DO PORTAL DO CONHECIMENTO DA ELETROBRAS ELETRONORTE.}

O tópico analisa os resultados dos questionários, com o objetivo de compreender o comportamento de pesquisa de informação dos usuários do Portal do Conhecimento da Eletrobras Eletronorte. Para tanto, toma-se o modelo de busca e uso da informação de Wilson (1981) conjugado à proposta de Dias (2001b). A proposta disponibilizada no referencial teórico deste trabalho - um modelo de comportamento de pesquisa da informação em portal corporativo - delimitou as variáveis de comportamento informacional consideradas no estudo no intuito de ampliar a eficácia e eficiência do processo de pesquisa da informação em portais corporativos. Como principais critérios de análise foram definidos acesso, competência e pertinência.

No estudo, destaca-se a interação dos ambientes de negócio e a influência para o usuário da informação e a organização, considerando o ponto de vista do usuário e a relação com as variáveis contextuais que podem influenciar a busca ou tornarem-se barreiras ao processo.

\footnotetext{
${ }^{39}$ Fonte: Relatório de Sustentabilidade 2012, p. 56.

${ }^{40}$ Idem.
} 


\subsubsection{Os acessos dos usuários}

O presente tópico analisa o acesso dos usuários ao Portal do Conhecimento, com o objetivo de identificar fatores que estimulam e potenciais obstáculos encontrados na pesquisa da informação qualificada. Os resultados demonstram que o portal poderia ser mais acessado, apesar de ser ferramenta reconhecida pela importância estratégica e tática, uma vez que a maioria dos entrevistados utiliza informações e documentos que compõem o conteúdo do portal para a tomada de decisão, provavelmente porque o usuário localiza e acessa a informação qualificada sem dificuldades.

Há pequena representação dentre os respondentes que usam com pouca frequência o portal, o que pode ser indicativo de dificuldade de uso e sugerir atenção por parte dos gestores sobre o real motivo por detrás destas complicações. O layout do portal, considerado por Dias (2001b) um dos facilitadores da localização de informações foi testado no estudo, e boa parte dos entrevistados afirma haver boa comunicação visual na ferramenta, dados contestados por quase metade dos respondentes, ao indicarem possuir dificuldades para pesquisar informações no portal, praticamente um empate técnico.

A espacialidade é ponto importante para o portal, pois associada à construção de conteúdos com determinada lógica, disponibilizados de forma ergonômica, favorece a consulta por parte do utilizador ao demandar alguma informação corporativa (CORRÊA, 2008). Cabe questionar se a discordância seria receio de admitir a incapacidade, mesmo que momentânea, em lidar com a tecnologia. O perfil dos respondentes mostra que grande parte dos profissionais situa-se na faixa etária de pessoas mais maduras, acima de 46 anos, portanto não pertencem à chamada Geração $\mathrm{Y}^{41}$, o que pode ser um dos motivos que os levam a não se interessarem pela ferramenta portal.

Vale ressaltar que a busca de informação é um processo interativo, que varia ao longo do tempo e do contexto relacionados, e sofre a influência de fatores de origem social, institucional e tecnológica; dos recursos de informação à disposição dos usuários; do meio cultural, dentre outros (COURTRIGHT, 2007). Desta forma, evidencia-se a importância da existência de estímulos da organização e dos dirigentes à participação do usuários na produção de novos conteúdos para o portal. Os resultados do estudo demonstram que proporção relevante dos pesquisados reconhecem que a Eletrobras Eletronorte oferece

41 Geração Y, também conhecida como geração do milênio ou geração da Internet, é a denominação das pessoas concebidas na era digital, ou seja, após o surgimento da internet nos anos 80. (PAVONI, 2010). 
condições e recursos que incentivam e facilitam o compartilhamento, a coleta de ideias, informações e sugestões entre os usuários, aspectos corroborados por Saldanha (2012). Paralelamente, a divulgação de novos conteúdos disponibilizados pode ser um catalisador no processo de consultas ao portal, algo que quase a totalidade dos pesquisados afirmam ocorrer na Eletrobras Eletronorte.

Considerando a importância da disponibilidade de recursos que venham a facilitar o processo de pesquisa da informação em um portal corporativo (MORESI; MENDES, 2010), os resultados mostram que grande parte dos respondentes reconhece a existência dos recursos do portal e que a apresentação de resultados da pesquisa da informação realizada no portal é satisfatória. Em contrapartida, novamente uma porção significativa dos pesquisados discorda ou não soube opinar. Pode-se entender que há espaço para implantação de melhorias no portal, tais como ferramentas de busca, operadores booleanos, dentre outros, bem como capacitação dos usuários em pesquisa da informação. Afinal, os profissionais precisam ter competência na busca e uso da informação qualificada para saberem analisar e monitorar os ambientes de negócio (CHOO, 2006), uma vez que a utilidade da informação está relacionada a critérios identificados pelo usuário, tais como relevância, qualidade da apresentação e quantidade (BEAL, 2007).

A que se considerar ainda no processo de geração do conhecimento organizacional que a informação é produto perecível, isto é, perde valor a medida que o tempo passa, o valor aumenta na proporção do uso e quando há combinação de informações, o que torna essencial a multiplicação por processos como síntese, combinação e análise (BEAL, 2007). No estudo, a maioria dos respondentes concorda que o Portal do Conhecimento da Eletrobras Eletronorte atende a prerrogativa da promoção do uso e do compartilhamento dos conteúdos disponibilizados, aspectos relevantes para caracterizar portais corporativos (SALDANHA, 2012).

\subsubsection{A competência técnica para realizar pesquisa da informação}

A seção abrange reflexões sobre a competência técnica do usuário necessária para realizar pesquisa da informação no portal. De acordo com Gasque (2008), as competências necessárias para busca e uso da informação pressupõem conhecimentos que possibilitem encontrar a informação pertinente e relevante para o usuário. Isso exige que o indivíduo tenha consciência da necessidade da informação, da mesma forma que é essencial saber como e onde encontrar a informação. 
Para interpretar e monitorar os ambientes de negócios, os profissionais devem ter competência para realizar a busca e usar a informação qualificada, visto que o conhecimento organizacional é gerado pelo conjunto de esforços de indivíduos compartilhando experiências e construindo significados (CHOO, 2006). As TICs são essenciais, porém, entram como coadjuvantes no processo por viabilizarem a disseminação da informação de maneira descentralizada e rápida (MIRANDA, 2003). O estudo demonstra que metade dos respondentes possui conhecimento de técnicas de pesquisa da informação, em oposição à outra parte dos pesquisados que afirma desconhecer meios que facilitam a busca da informação no portal. Pode-se inferir que esta situação ratifica as situações encontradas na questão anterior quanto à dificuldade para acessar as informações no portal. Parte das respostas mostra que poucos fazem uso de técnicas próprias para a pesquisa da informação, provavelmente pelo uso inadequado das TICs, ao se considerar que os respondentes conseguem localizar e acessar com facilidade a informação/documentos no portal, porém alguns entendem que não possuem competência informacional para lidar com processos mais elaborados de pesquisa.

Os resultados mostram que o usuário do portal reconhece a informação como insumo importante no processo de tomada de decisão e consegue perceber o momento em que precisa de informação, onde pode ser encontrada e como consegui-la. Por outro lado, boa parte dos respondentes possui dificuldades para identificar as fontes e os canais de informação qualificada, além de desenvolver estratégias eficientes de busca. Pelos resultados, mesmo julgando-se capazes de localizar e acessar com êxito a informação e integrá-la aos conhecimentos pré-existentes, ainda assim os respondentes estão receptivos à capacitação na área. Isso mostra que reconhecem que precisam aprender mais sobre o assunto.

Entre os participantes da pesquisa que confirmaram usar técnicas e ferramentas para pesquisa de informações, a maioria utiliza basicamente o campo de busca do portal associado à outros recursos, quais sejam: verbetes e palavras-chave; dados lógicos, tais como assuntos específicos, títulos, autores e o Banco Achei - banco de currículos eletrônicos da organização. Apesar disso, a maioria dos pesquisados explicitam interesse em aprender técnicas e ferramentas para auxiliar na pesquisa de informação em situações futuras, muito provavelmente por se tratar de profissionais qualificados que reconhecem o atual contexto de competitividade e a importância do emprego eficaz da informação no cotidiano. Isso demonstra como os vários ambientes podem provocar estímulos ou constituírem-se em barreiras para a formação do indivíduo (WILSON, 1981). 
Atualmente, além da disponibilidade de informação para o profissional, a organização deve garantir o processo de aprendizagem, contínua e progressivamente, para que o colaborador saiba lidar com a grande quantidade de fontes e recursos de informação. A institucionalização da aprendizagem organizacional (ApO) como meio para o desenvolvimento da pesquisa e desenvolvimento prepara a organização para enfrentar as rápidas mudanças tecnológicas sobre os ambientes de negócios (FERNANDES, 1999). Desta forma, pode-se entender que os profissionais precisam de qualificação própria, que os habilitem a desempenhar novos papéis que exigem conhecimentos multidisciplinares (BAPTISTA, 2007).

\subsubsection{A utilidade da informação para a tomada de decisão e o compartilhamento da informação}

A seção aborda a utilidade da informação para a tomada de decisão e o compartilhamento da informação por parte do usuário. A ideia é caracterizar o atendimento do Portal do Conhecimento à demanda dos usuários de informação qualificada. As necessidades de informação originam-se quando indivíduos percebem lacunas no conhecimento existente, que precisam ser preenchidas, a fim de dar sentido a algo que possa contribuir com algum processo relevante (WILSON, 2000).

A informação tem valor reconhecido no processo de tomada de decisão ao reduzir as incertezas (BELKIN,1978). Os resultados do estudo mostram que os respondentes realizam pesquisas de informação no portal sobre o histórico de decisões já tomadas. Mas, o destaque fica para as buscas realizadas para subsidiar alguma ação ou decisão atual e para dar suporte a decisões futuras, o que demonstra a importância do portal no processo de tomada de decisão. Diante deste contexto, a pesquisa da informação no portal está relacionada às decisões que apoiam o processo de planejamento, bem como empresas que incentivam o desenvolvimento do conhecimento organizacional na obtenção da vantagem competitiva (CHOO, 2006).

Tal fato aparece mais claramente nas proposições sobre os motivos apontados pelos respondentes para a realização da busca da informação no portal, em que a maioria procura conteúdos técnicos, referentes às estatísticas, dados de mercado, publicações técnicas, etc., com o objetivo de se atualizar sobre produtos e serviços da Eletrobras Eletronorte. Para tanto, pesquisam em revistas e jornais internos, comunicados e demais informações da organização. Ratificando os dados, as estatísticas de acesso demonstram o interesse dos colaboradores nas áreas técnicas e de produtos da empresa, haja vista que os conteúdos mais acessados em 
agosto de 2012 foram: acervo online, normas técnicas, banco de inovação e painel interno de melhoria (PIM). Em verificação mais recente, em agosto/2013, pôde-se encontrar basicamente os mesmos interesses: acervo online, normas técnicas, Programa de Identificação e Compartilhamento do Conhecimento Crítico (PICC), Semana Eletronorte do Conhecimento e Inovação (SECI) e Banco de Monografias, Dissertações e Teses dos empregados (BMDT).

Decisões bem sucedidas têm origem na qualidade da informação provida e na capacidade dos profissionais que tomam a decisão, para interpretá-la e usá-la na escolha de melhores alternativas (BEAL, 2007). O estudo aponta também que a pesquisa feita no portal com intenção de atualização sobre informações políticas, por exemplo, regulamentações do setor e legislação em geral, é constante para grande parte dos participantes, muito provavelmente devido ao setor de energia ser uma área controlada pelo governo. Além disso, outros fatores demandam conhecimento de legislação e contratos, tais como diversas obras em parceria com empresas particulares e milhares de colaboradores sob condições contratuais diferenciadas - que envolvem compra e/ou locação de infraestrutura; maquinário de grande porte; importações e flutuação de câmbio; contratação de pessoal terceirizado; dentre outras ${ }^{42}$. Trata-se, portanto, de contexto passível de alterações constantes conforme demanda da economia.

Diante deste contexto, é curioso obervar que o estudo aponta interesse menor do usuário quando se trata da atualização sobre o mercado e área de negócios, embora com certa expressividade. Também merece atenção o índice de respostas negativas para essa questão: 1/3 dos usuários não utilizam o portal para esta finalidade, o que é compreensível, uma vez que o portal não apresenta indicadores ou conteúdo relacionados com tal especificidade. Pressupõe-se que os colaboradores devem recorrer a outras fontes como portais de organizações ligadas à economia e ao mercado, jornais e revistas de negócios. A situação pode ser interpretada como oportunidade para o portal ampliar os serviços e, muito provavelmente, aumentar o número de acessos e usuários.

Quanto ao compartilhamento de informações, vale salientar que se trata de fator preponderante para as organizações o emprego de sistemas para desenvolver, armazenar e transferir informação entre diversos colaboradores e o ambiente de negócios, continuamente, como meio de geração de conhecimento organizacional (SGUARIO; TOMAÉL, 2011). No estudo, cerca da metade dos respondentes utilizam o portal com o objetivo de localizar profissionais e potenciais parceiros para realização de projetos, por exemplo. Dos

\footnotetext{
${ }^{42}$ Eletrobras Eletronorte, Relatório de Sustentabilidade 2012.
} 
respondentes, mais de 1/3 dos pesquisados não o usa para essa finalidade, o que sugere que não percebem a utilidade do portal para este fim. A questão foi considerada no estudo em virtude da funcionalidade do Banco Achei, que lista os profissionais da empresa como um banco de currículos, e pela importância da colaboração de indivíduos na combinação de informações, o que aumenta o valor da informação, aspectos defendidos por Beal (2007) e Saldanha (2012).

A Eletrobras Eletronorte parece estar ciente de que a ApO contribui para o desenvolvimento de competências gerenciais, essenciais para construção de ambientes favoráveis à gestão do conhecimento e à inovação (BITENCOURT, 2001). Por isso, promove eventos para capacitação e motivação dos empregados a respeito da importância do desenvolvimento do conhecimento organizacional e da sustentabilidade, realizados por meio de $\mathrm{P} \& \mathrm{D}$, painéis temáticos, prêmios de reconhecimento, fóruns de inovações, soluções e melhorias em produtos. Contudo, a baixa frequência dos funcionários em cursos ou eventos gerenciais, pode estar associada à dificuldade na divulgação dos eventos. Existem mais de seis portais na empresa, além da intranet, o que facilitam a dispersão da atenção dos empregados, para além de diversos campi de obras espalhados pela Região Norte do país. De acordo com os gestores da GAE, parece haver uma cultura disseminada na organização de não ler $e$-mails, atribuída ao fato de que os colaboradores recebem diariamente enorme quantidade de mensagens no correio eletrônico, selecionando remetentes e assuntos de interesse do momento, apagando as demais mensagens sem que haja leitura prévia, tal e qual fazem com banners ou pop-ups utilizados no sítio da empresa com esta finalidade. Há que se considerar a possibilidade de simples desmotivação dos colaboradores pelo tema/assunto abordado, o que tem levado os responsáveis pelos eventos a usarem recursos diferenciados como incentivos extras para atrair o público-alvo, tais como sorteio de brindes, lanche diferenciado, dentre outros.

De acordo com os gestores da GAE, existem diversas ilhas de excelência na organização, o que torna essencial incorporar a ideia de compartilhamento de informações dentre os empregados. A organização possui plataforma própria para incentivar a interação entre usuários, embora trata-se de proposta que ainda não está amadurecida na opinião dos gestores. Na Eletrobras Eletronorte, há políticas que versam sobre o fornecimento de material para o acervo da biblioteca da organização, condição obrigatória em casos que a empresa patrocina o curso de colaboradores. Somando-se a estes esforços, existem diversos programas para incentivar o compartilhamento de informação, que envolve a conversão do conhecimento 
tácito dos colaboradores, sistematização e transformação dele em conhecimento institucional passível de ser compartilhado.

Por fim, o acesso às comunidades virtuais e aos informativos disponibilizados no Portal do Conhecimento da empresa compõem outros meios de compartilhamento de informações para os colaboradores da Eletrobras Eletronorte. Porém, parece os recursos e condições parecem subaproveitados, como outros recursos do portal, uma vez que a disponibilidade de informação qualificada aparece de maneira diluída dentre diversas fontes, fato que pode contribuir com a dispersão do usuário e a morosidade na tomada de decisão.

\subsubsection{Opiniões sobre o processo de pesquisa e natureza da utilização das informações obtidas a partir do portal do conhecimento da Eletrobras Eletronorte}

O presente tópico explora a opinião dos respondentes sobre o processo de busca e natureza da utilização das informações obtidas a partir do portal. Os comentários foram agrupados em conteúdos similares e categorizados para viabilizar o processo de tabulação.

Interessante destacar que a maioria dos respondentes não registrou quaisquer manifestações em relação ao portal. Pode-se inferir que os usuários consideram que os pontos essenciais do portal foram abordados satisfatoriamente Por outro lado, existe a possibilidade de interpretar a ausência de respostas como falta de motivação para descrever algo.

Os comentários realizados pelos respondentes do instrumento de coleta de dados mostram contribuições relevantes para a melhoria no Portal do Conhecimento da Eletrobras Eletronorte. Para tanto, foram categorizados em cinco pontos, quais sejam:

a) Dispersão das informações nos diversos portais da organização;

b) Necessidade de melhorar a divulgação do portal;

c) Falta de incentivo ao uso do Portal do Conhecimento;

d) Necessidade de atualização das informações;

e) Modernização do layout do portal e promoção da integração com demais sistemas da empresa.

Os dados condizem com as proposições de valor de portais corporativos, defendidas por Saldanha (2012), que abrangem Integração, Conteúdo e Colaboração. As questões relacionadas à necessidade de maior divulgação e ao incentivo do uso do Portal do Conhecimento são apontados pelos respondentes como igualmente importantes. 
De acordo com Dias (2001b), o portal deve possibilitar o acesso dinâmico às informações que armazena, de tal forma que os usuários recebam informações atualizadas constantemente. O estudo demonstra que os usuários não percebem, com frequência, as atualizações dos conteúdos do Portal Corporativo da Eletrobras Eletronorte, e em particular, indicam que o portal precisa de atenção quanto às revisões ortográficas e às correções de erros gramaticais. Trata-se de pontos que podem interferir na percepção de como os usuários avaliam o portal como fonte de pesquisa fidedigna, situação que pode levar o usuário ao desinteresse em realizar novas buscas (SALDANHA, 2012).

Outro fator destacado nos comentários dos respondentes diz respeito à necessidade de modernizar o layout e promover a integração dele às demais áreas da empresa. Isso parece equivaler à proposição de Dias (2001b) e Saldanha (2012) ao relacionar a importância da integração em TI, associada à atenção ao conteúdo e à colaboração como principais proposições de valor de um portal corporativo. 


\section{CONCLUSÃO}

A pesquisa originou-se do pressuposto de que o portal corporativo constitui-se recurso essencial no processo de tomada de decisão, por ampliar a acessibilidade, disponibilidade e o uso da informação para o usuário. Profissionais de diversas áreas do conhecimento necessitam constantemente de informação qualificada e, ao mesmo tempo, demandam o emprego eficaz da informação como meio de obtenção de vantagem competitiva para as organizações em que atuam.

Para isso, o tópico apresenta resumo da análise dos resultados provenientes do estudo sobre o comportamento de pesquisa da informação de usuários de portais corporativos para tomada de decisão. Em seguida, apresentam-se as conclusões em relação aos objetivos, as recomendações e contribuições teóricas e práticas da pesquisa.

\subsection{ANÁLISE DOS RESULTADOS}

\subsubsection{Objetivo 1: dados gerais sobre a empresa e o objeto de pesquisa.}

O estudo está em conformidade com o contexto científico e com os padrões do PPGCInf, uma vez que aborda estudo de caso relevante para qualquer área de negócio que utiliza a ferramenta portal corporativo como meio de acesso rápido à informação qualificada para a tomada de decisão.

Constata-se que a Eletrobras Eletronorte realiza diversos esforços para incentivar a criação e compartilhamento do conhecimento organizacional, envolvendo sistemas de informação, programas empresariais de capacitação e incentivo, com o propósito de tornar-se competitiva, conforme definido em seu planejamento estratégico. No entanto, o estudo demonstra dificuldades no atendimento a este objetivo organizacional em virtude da oferta numerosa e dispersa de informações, dispostas em diversos sistemas, alguns com funcionalidades ainda em construção e, consequentemente, subutilizadas pelos colaboradores. Outro ponto observado no estudo é que boa parte do pessoal não desenvolveu técnicas de busca e pesquisas de informação necessárias para lidar com tal variação de funcionalidade, o que acaba fragmentando e descaracterizando a proposta de um sistema de gestão integrada de informações.

Para atender a referida proposta, a empresa incentivar as pesquisas, emprego e compartilhamento de informações qualificadas, que possam embasar decisões de forma eficaz 
e eficiente. O Portal do Conhecimento pode colaborar de forma decisiva no auxílio à gestão do conhecimento, desde que sejam realizadas algumas alterações, propostas mais adiante.

\subsubsection{Objetivo 2: descrição dos serviços disponibilizados e os recursos informacionais do portal do conhecimento da Eletrobras Eletronorte.}

Os dados coletados durante a investigação demonstram que o portal apresenta diversas funcionalidades apropriadas ao suporte à decisão, com boa comunicação visual, por exemplo, disponibilidade de textos, cores, grafias, etc. e devidamente segmentado. Parte das funcionalidades é desconsiderada pelo baixo índice de acessos, muito provavelmente por conta da dispersão de informações qualificadas em diversas fontes similares. Existem seis portais, a intranet, o sítio da empresa, além do sítio da controladora, a Eletrobras.

A pesquisa em questão identifica haver demanda dos usuários para atualização, revisão gramatical e ortográfica do conteúdo, bem como modernização do layout. Além disso, nota-se a inexistência de conteúdo voltado para a área de mercado/negócios, como indicadores financeiros e econômicos, dentre os vários itens que podem ser agregados de formas a contribuir com a atratividade e usabilidade do portal. Para efeitos práticos, tais sugestões foram agrupadas e categorizadas, e integram a proposição de contribuições práticas deste estudo, descritas em item mais adiante.

\subsubsection{Objetivo 3: identificação do perfil dos usuários do portal do conhecimento Eletrobras Eletronorte}

O perfil dos respondentes da pesquisa pode ser descrito como profissional experiente, qualificado para enfrentar os desafios profissionais. Os usuários possuem ensino superior, incluindo especializações, ocupam cargo de nível superior, poucos em cargos de níveis gerenciais e estão há muito tempo na empresa. A maioria é do gênero masculino e situa-se na faixa etária acima dos 46 anos.

Desde 2012, a empresa segue a Política de Gestão de Pessoas padronizada pelo Sistema Eletrobras, que define diretrizes de adequação ao que foi denominado modelo de carreira com foco em competência e resultados. Outro incentivo à constante capacitação é o Plano de Carreira e Remuneração (PCR) da Eletrobras Eletronorte, além de planos específicos para o desenvolvimento do conhecimento organizacional e de inovação. Para tanto, existem diversos programas, com implantação de processos e ferramentas, somados a criação de 
equipes e áreas específicas de fomento a gestão da informação e capacitação de seus profissionais.

\subsubsection{Objetivo 4: mapeamento dos padrões de comportamento de pesquisa da informação dos usuários do Portal do Conhecimento da Eletrobras Eletronorte.}

O presente estudo fundamenta-se no modelo de busca e uso da informação de Wilson (1981) conjugado à proposta de Dias (2001b), que delimita as variáveis utilizadas nesta pesquisa: acesso, competência e pertinência. Os resultados das análises foram classificados em indicativos de obstáculo ou de estímulo à pesquisa da informação, explicitados a seguir.

a) Possíveis obstáculos à pesquisa da informação:

a.1) acesso à informação:

- Localização - os resultados da pesquisa mostram haver inúmeras fontes de informações na empresa, dispersas em diversos portais, na intranet e nos sítios da Eletronorte e da Eletrobras, o que inviabiliza e/ou atrasa a localização das informações;

- Divulgação do portal - dentre os diversos problemas que inibem o volume de acessos, a pesquisa apresenta o pouco incentivo ao uso do Portal do Conhecimento por parte de líderes e gestores, provavelmente, também relacionado à dispersão de informações. Os respondentes indicaram na pesquisa pouca divulgação das ferramentas, conteúdos e facilidades do portal, apesar dos esforços realizados pela equipe de gestores do portal (GAE), em conjunto a equipe de comunicação organizacional da Eletrobras Eletronorte;

- Usabilidade/atratividade - os entrevistados não percebem variação do layout, sugeriram a modernização do mesmo e parecem associar isso diretamente à falta de atualização de informações e documentos. Outro fator presente no estudo é a demanda dos usuários em relação às revisões ortográficas e correções de erros gramaticais no conteúdo disponibilizado, fato que compromete a credibilidade de qualquer meio de comunicação. Apesar de haver diversos documentos disponibilizados de forma digitalizada, ainda existe material a digitalizar. Parece importante completar esta fase, uma vez que a questão de acesso rápido à consulta remota é desejo de usuários de qualquer sistema. Ainda, para atuar no 
mercado, os profissionais necessitam ter prontidão nas decisões, sob pena de perder competitividade;

- Integração - pelos dados coletados, observa-se que o portal não está integrado às demais áreas e/ou sistemas da empresa, fato gerador de retrabalho, redundância e informações desatualizadas, ocasionando desmotivação para usuário acessar o portal, levando-o a buscar outra fonte como referência;

a.2) letramento informacional:

- Pesquisa da informação - as investigações apontam problemas de funcionamento nas ferramentas de busca do portal, o que complica o processo de busca, uma vez que se trata de ferramenta própria para pesquisa intuitiva. Os usuários estão habituados a utilizar em virtude da semelhança ao browser da internet. Os resultados também demonstram que muitos usuários não consideram que sabem fazer pesquisa de informação, categorizar ou classificar a informação. Tal circunstância pode ser constitui-se em oportunidade a capacitação adequada dos colaboradores, bem como a divulgação das inúmeras facilidades do portal;

- Compartilhamento da informação - a Eletrobras Eletronorte realiza eventos, disponibiliza ferramentas, mas ainda existem problemas com o compartilhamento da informação, conforme indicada a pesquisa realizada. Os respondentes apontam ausência de incentivos por parte de gestores e líderes para promoverem o compartilhamento da informação, além da ausência de ferramentas. Tal fato parece relaciona-se à baixa percepção do usuário sobre as condições providas pela organização ou ao uso inadequado das ferramentas, fato que ratifica a necessidade de desenvolver processos de letramento informacional na empresa.

a.3) pertinência da informação:

- Atendimento à demanda - dados revelam que os pesquisados estão satisfeitos com o conteúdo disponibilizado. Por outro lado, apontam ausência de atualização de informações e documentos, além de ampliar a oferta de documentos digitalizados, que permite consultas rápidas remotamente. Não foi encontrado no portal conteúdo que abrange informações da área de negócios, tais como índices financeiros e de 
mercado; notícias recentes sobre o setor, dentre outros. Vale salientar que existem poucas informações sobre negócios disponíveis nos informativos, que parecem enfatizar informações sobre a organização. Contudo, deve-se considerar o tempo entre a divulgação de uma notícia econômica no mercado, por exemplo, que posteriormente é encaminhada para seleção, redação de conteúdo, editoração e publicação do material impresso. Nesse sentido, poderia haver melhor aproveitamento dos recursos multimídias ofertados pelo meio digital. Um exemplo seria disponibilizar, em um campo específico para notícias, parte da informação recém-divulgada e disponibilizar link para que o usuário acesse todo o conteúdo, se assim desejar.

b) Fatores que podem estimular a pesquisa da informação

b.1) acesso à informação

- Localização - centralizar o Portal do Conhecimento tem potencial para se tornar fonte essencial aos principais recursos informacionais da organização. Para isso, deve centralizar o acesso aos demais portais e informações estratégicas no Portal do Conhecimento, viabilizando-o como ferramenta essencial para o processo de tomada de decisão eficaz. Para não haver dispersões e concorrências, pode-se dispor na intranet atividades operacionais, ainda assim, com acesso via portal.

- Divulgação do portal - marketing da unidade de informação: apesar de intensos esforços da equipe da GAE e do setor de comunicação, o estudo demonstra a necessidade de promover o portal. Para isso, uma campanha interna de promoção da unidade de informação Portal do Conhecimento, com peças on e off-line, pode ser o catalisador do processo. Em associação, os gestores podem colaborar com a indicação do portal. Outro fator que pode contribuir é a centralização das atividades de pesquisa da informação no portal.

- Usabilidade/atratividade:

- Atualização: o portal deve possibilitar o acesso dinâmico às informações que armazena, de tal forma que os usuários recebam informações atualizadas constantemente. Existem ferramentas próprias 
que permitem atualização em tempo real de notícias, que podem ser alocadas no portal, tais como o $\mathrm{RSS}^{43}$;

- revisão: os respondentes apontaram problemas com a gramática e ortografia nos conteúdos disponibilizados. Instituir a figura do revisor de conteúdo deve evitar esse tipo de problema e até a incursão de redação mais amigável aos usuários;

- design: o estudo também indica a demanda por alterações eventuais no layout, para gerar a sensação de modernidade e atualização de conteúdo. Uma sugestão seria a instalação de ferramentas que viabilizem a personalização do layout do portal, definido pelo usuário e não pelo webmaster, a exemplo do que acontece com sítios de alguns bancos.

- Integração:

- Identificação de demanda: uma indicação seria promover pesquisa interna em busca de sugestões de conteúdo;

- Participação: criar meios para que os colaboradores possam se interessar em enviar materiais, constantemente. Desta forma, incentivase à escrita colaborativa, o compartilhamento de conhecimento organizacional e os usuários se sentem mais prestigiados, o que pode aumentar o índice de acessos e colaborar na divulgação do portal

- Conexão: viabilizar a integração com outros sistemas de informação da organização com atenção à segurança, uso de ferramentas próprias para segurança da informação. Isso também deve facilitar o compartilhamento do conhecimento e minimizar problemas como atualização e redundância de informações.

b.2) letramento informacional:

- Pesquisa da informação:

- Funcionalidade: resultados da pesquisa demonstram necessidade de melhorar funcionalidade da ferramenta de busca do portal, incluindo

43 RSS significa Rich Site Sumary ou Really Simple Syndication. Trata-se de formato que permite distribuir o conteúdo de sítios de notícias de maneira padronizada, permitindo que seja lido em diversos aplicativos, como leitores de notícias. Ao usar RSS, o usuário fica sabendo imediatamente quando a informação do seu interesse é publicada, sem que tenha que navegar até o sítio de notícias. (INTERNEY. O que são feeds RSS ?. Disponível em http://www.interney.net/blogfaq.php?p=9741544>. Acesso em 14 set. 2013). 
provisão de recursos para a classificação e a pesquisa intuitiva, tais como dicas de pesquisa, por exemplo, o uso dos operadores booleanos, ferramentas de ajuda, dentre outros;

- Capacitação: a empresa precisa promover formação adequada para usuários se habilitarem à pesquisa, uso e transferência da informação, centrando nos incentivos aos potenciais resultados da formação;

- Transmissão da informação e compartilhamento de conhecimento: instaurar recursos que viabilizem a troca de informações para além do Portal Share Point. Incentivar o uso das comunidades virtuais - cujo acesso está no Portal do Conhecimento, mas está redirecionamento à UCEL. Da mesma forma, o Programa de Identificação e Compartilhamento do Conhecimento Crítico (PICC) deve ganhar maior visibilidade, ou seja, incentivo para acessá-lo e contribuir com conteúdo;

- Troca entre stakeholders: otimização da ferramenta denominada Banco Achei, que possibilita a localização de profissionais na empresa especialistas em áreas específicas de determinados projetos. A ideia é incentivar o compartilhamento do conhecimento organizacional.

b.3) pertinência da informação:

- Atendimento à demanda: a função primordial do portal passa pela satisfação das necessidades de informação dos usuários da organização. Para tanto, pode-se ofertar ferramentas inteligentes de negócios devidamente integradas que possam servir para atualização do usuário sobre o mercado e área de negócios, tais como aplicativos que proporcionem alimentação constante/simultânea a dados específicos da área, selecionados pelo próprio usuário em conformidade com suas demandas profissionais e pessoais.

\subsection{CONTRIBUIÇÕES TEÓRICAS DO ESTUDO}

O presente trabalho desenvolveu um modelo teórico a partir do modelo de comportamento informacional de Wilson (1981). A ideia foi representar as variáveis de 
comportamento de pesquisa da informação dos usuários de portais corporativos, evidenciando a ação de influências e potenciais barreiras que atuam no processo de pesquisa da informação.

O modelo proposto no estudo também destaca a interação dos ambientes de negócios e a influência sobre o usuário e a organização. Da mesma forma, considera o ponto de vista do usuário e as variáveis contextuais - que ora influenciam a busca ora podem se tornar barreiras ao processo. As questões mostraram-se relevantes no estudo, ao se identificar que o valor da informação aumenta quando há combinação de informações, da mesma forma que a utilidade da informação é definida pelo usuário, por critérios como relevância, qualidade da apresentação e quantidade, o que ratifica a importância do Portal do Conhecimento como provedor de informação qualificada, associada à facilidade de acesso, armazenamento e disseminação do conhecimento organizacional.

A pesquisa aponta ainda a necessidade do usuário se capacitar adequadamente para saber buscar, selecionar, processar e compartilhar a informação, tornando-o apto a construir significados, dar sentido à informação e tomar decisões.

\subsection{CONTRIBUIÇÕES PRÁTICAS DO ESTUDO}

A proposta do estudo é ressaltar características que podem levar o Portal do Conhecimento da Eletrobras Eletronorte - e outros portais corporativos com características similares - a tornarem os principais recursos informacionais da organização, viabilizando-o como ferramenta essencial para o processo de tomada de decisão eficaz. De acordo com Carvalho (2006), a gestão dos ativos do conhecimento de uma organização é essencial para melhorar seu desempenho, e o estudo evidencia a importância dos profissionais no processo que, associados aos equipamentos e processos adequados podem gerar ótimos resultados. “[...] o momento atual aponta para uma evolução ainda mais significativa, com a introdução de sistemas e ferramentas que enfatizam e dão validade à produção de conteúdos e mensagens por parte do usuário" (CORRÊA, 2008, p. 171).

Cabe à organização realizar atividades com objetivo de agregar valor à informação e disseminá-la eficientemente, tornando-a apta a tomar decisões eficazes e selecionar estratégias adequadas para serem adotadas, considerando clientes, concorrentes, ciclo de vida de produtos; bem como identificar fontes de informações relevantes, gerenciando dados e informações. 
A seguir, estão condensadas sugestões advindas do estudo em que a organização pode se amparar, a fim de evitar os obstáculos à pesquisa da informação e potencializar os fatores que podem estimular usuários na busca da informação.

Quadro 10 - Mapeamento de obstáculos e estímulos à pesquisa da informação no portal do conhecimento Eletrobras Eletronorte.

\begin{tabular}{|c|c|c|c|}
\hline \multicolumn{2}{|c|}{ Variável } & Possíveis obstáculos à & Fatores que podem estimular a pesquisa da informação \\
\hline \multirow{3}{*}{ 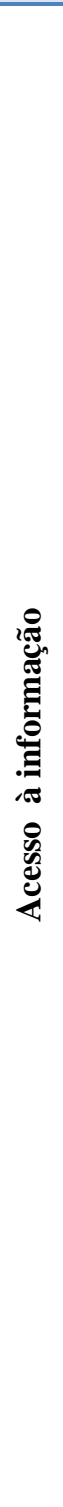 } & 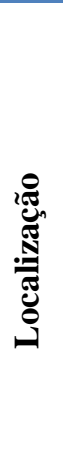 & $\begin{array}{l}\text { - Informações dispersas em } \\
\text { diversos portais e intranet } \\
\text { inviabilizam e/ou atrasam } \\
\text { a localização das informa- } \\
\text { ções. }\end{array}$ & $\begin{array}{l}\text { - Centralizar: tornar o portal o acesso primário aos } \\
\text { principais recursos informacionais da organização. } \\
\text { Centralizar acesso aos demais portais e informações } \\
\text { estratégicas no Portal do Conhecimento, viabilizando-o } \\
\text { como ferramenta essencial para o processo de tomada de } \\
\text { decisão eficaz. } \\
\text { - Dispor a intranet apenas para atividades operacionais e } \\
\text { corriqueiras. }\end{array}$ \\
\hline & 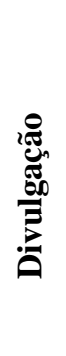 & $\begin{array}{l}\text { - Falta de incentivo ao uso } \\
\text { do Portal do Conhecimen- } \\
\text { to. } \\
\text { - Pouca divulgação das } \\
\text { ferramentas, conteúdos e } \\
\text { facilidades do portal. }\end{array}$ & $\begin{array}{l}\text { - Marketing da unidade de informação: GAE e o setor de } \\
\text { comunicação deve criar campanha interna para promover } \\
\text { a unidade Portal do Conhecimento, uma campanha com } \\
\text { peças on e off- line. }\end{array}$ \\
\hline & & $\begin{array}{l}\text { - Ausência de informações } \\
\text { e documentos atualizados, } \\
\text { disponibilizalizada (permita con- } \\
\text { sulta remota, com pronti- } \\
\text { dão). } \\
\text { - Faltam revisões ortográfi- } \\
\text { cas e correções de erros } \\
\text { gramaticais. } \\
\text { - Carência de modernização } \\
\text { do layout. }\end{array}$ & $\begin{array}{l}\text { - Atualização: possibilitar o acesso dinâmico às } \\
\text { informações que armazena, de tal forma que os usuários } \\
\text { recebam as informações atualizadas constantemente. } \\
\text { - Revisão: instituir a figura do revisor de conteúdo (textos, } \\
\text { imagens e documentos). } \\
\text { - Design: propor alterações eventuais no layout, para gerar } \\
\text { a sensação de modernidade e atualização de conteúdo. } \\
\text { Ver possibilidade de ferramenta que viabilize a } \\
\text { personalização do layout do portal, definido pelo usuário e } \\
\text { não pelo webmaster, a exemplo do que acontece com } \\
\text { sítios de alguns bancos. }\end{array}$ \\
\hline
\end{tabular}

Continua. 
Conclusão.

\begin{tabular}{|c|c|c|c|}
\hline & & $\begin{array}{l}\text { - O portal não está integra- } \\
\text { do às demais áreas e } \\
\text { sistemas da empresa, o } \\
\text { que pode gerar retrabalho, } \\
\text { redundância e/ou informa- } \\
\text { ções desatualizadas, oca- } \\
\text { sionando desmotivação } \\
\text { para usuário acessá-lo. }\end{array}$ & $\begin{array}{l}\text { - Identificação de demanda: promover pesquisa interna } \\
\text { - Participação: criar meios/ferramenta para que os } \\
\text { colaboradores possam se interessar em enviar materiais, } \\
\text { constantemente. } \\
\text { - Conexão: viabilizar a integração com outros sistemas de } \\
\text { informação da organização com atenção à segurança (uso } \\
\text { de ferramentas próprias para segurança da informação); }\end{array}$ \\
\hline \multirow{2}{*}{ : } & : & $\begin{array}{l}\text { - A ferramenta de busca do } \\
\text { portal não funciona ade- } \\
\text { quadamente, complicando } \\
\text { o processo de busca; } \\
\text { - Muitos usuários não } \\
\text { sabem fazer pesquisa de } \\
\text { informação, categorizar ou } \\
\text { classificar a informação; }\end{array}$ & $\begin{array}{l}\text { - Funcionalidade: melhorar funcionalidade da ferramenta } \\
\text { de busca do portal, incluindo provisão de recursos para a } \\
\text { classificação e a pesquisa intuitiva (dicas, ferramentas de } \\
\text { ajuda, dentre outros); } \\
\text { - Capacitação: promover formação adequada para usuários } \\
\text { se habilitarem à pesquisa, uso e transferência da } \\
\text { informação; }\end{array}$ \\
\hline & 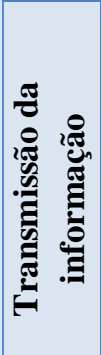 & $\begin{array}{l}\text { - Problemas com o compar- } \\
\text { tilhamento da informação } \\
\text { - ausência de ferramentas } \\
\text { e incentivos por parte de } \\
\text { gestores e líderes. }\end{array}$ & $\begin{array}{l}\text { - Compartilhamento de conhecimento: instaurar recursos } \\
\text { que permitam troca de informações e/ou ferramentas do } \\
\text { SharePoint; } \\
\text { - Troca entre stakeholders - possibilitar a localização de } \\
\text { profissionais na empresa que sejam especialistas em áreas } \\
\text { específicas de determinados projetos; }\end{array}$ \\
\hline : & 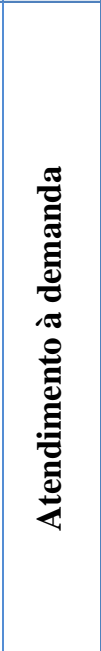 & $\begin{array}{l}\text { - Ausência de informações } \\
\text { e documentos atualizados, } \\
\text { e digitalizados (permita } \\
\text { consulta remoto) } \\
\text { - O conteúdo do portal não } \\
\text { abrange informações da } \\
\text { área de negócios e } \\
\text { mercadológicas. }\end{array}$ & $\begin{array}{l}\text { - A capacidade de satisfazer as necessidades de informação } \\
\text { dos usuários da organização dever do portal. Pode-se } \\
\text { obter bons resultados aproveitando melhor os recursos } \\
\text { multimídias, tais como notícias recém-divulgadas no } \\
\text { mercado que podem ser disponibilizadas de forma } \\
\text { dinâmica, com links direcionando o usuário interessado } \\
\text { para o sítio específico. } \\
\text { - Ofertar ferramentas inteligentes de negócios devidamente } \\
\text { integradas (aplicativos), que possam servir para } \\
\text { atualização do usuário sobre o mercado e área de } \\
\text { negócios. }\end{array}$ \\
\hline
\end{tabular}

Fonte: elaboração própria.

O Portal Corporativo da Eletronorte destaca-se como recurso importante que amplia de forma significativa a acessibilidade, disponibilidade e o uso da informação ao público-alvo da empresa que, associado a técnicas motivacionais e processos de ApO utilizados pela 
organização propiciam o processo da aprendizagem coletiva (MORESI; MENDES, 2010). Por outro lado, analisando as opiniões expressadas pelos pesquisados, pode-se encontrar contribuições relevantes para melhorias no Portal do Conhecimento da Eletrobras Eletronorte que, se não consideradas, podem levar à evasão de usuários.

O estudo conclui que o Portal do Conhecimento é bastante utilizado pelos profissionais da empresa para a tomada de decisão, mas merece investimentos - de ordem técnica, ergonômica e motivacional, no intuito de ampliar o alcance e, consequentemente, elevar o número de acessos de usuários. 


\section{REFERÊNCIAS}

ABE, Veridiana; CUNHA, Miriam Vieira da. A busca de informação na Internet: um estudo do comportamento de bibliotecários e estudantes de ensino médio. TransInformação, Campinas,SP, v. 23, n. 2, p. 95-111, mai./ago.2011. Disponível em: <http://periodicos.puccampinas.edu.br/seer/index.php/transinfo/article/view/470>. Acesso em: 20 jun. 2013.

AMARAL, Sueli Angélica do. (Org.) Marketing na ciência da informação. Brasília: Universidade de Brasília, 2007.

BAPTISTA, Sofia Galvão. Técnicas de marketing para gestores de unidades de informação. In: AMARAL, S. A. do (Org.) Marketing na Ciência da Informação. Brasília: UnB, 2007.

BARROS, Aidil Jesus da Silveira; LEHFELD, Neide Aparecida de Souza. Fundamentos de metodologia científica: um guia para a iniciação científica. 2. ed. São Paulo: Makron Books, 2000 .

BEAL, Adriana. Gestão estratégica da informação: como transformar a informação e a tecnologia da informação em fatores de crescimento e alto desempenho. São Paulo: Atlas, 2007.

BELKIN, Nicholas J. Information concepts for information science. Journal of Documentation, v.34, n.I, p.55 - 85, mar. 1978.

BEMFICA, Juliana do Couto; BORGES, Mônica Erichsen Nassif. Aprendizagem organizacional e informação. Ciência da Informação, Brasília, v. 28, n. 3, p. 231-238, set./dez. 1999. Disponível em:

<http://revista.ibict.br/ciinf/index.php/ciinf/article/viewFile/283/250>. Acesso em: 26 set. 2008.

BITENCOURT, Cláudia Cristina. A gestão de competências gerenciais: a contribuição da aprendizagem organizacional. Tese (Doutorado em Administração) Programa de PósGraduação em Administração. Universidade Federal do Rio Grande do Sul. Porto Alegre, 2001. Disponível em: <http://hdl.handle.net/10183/1793>. Acesso em: 22 jan. 2011.

BUCKLAND, Michael K. Information as thing. Journal of the American Society for Information Science (JASIS), v.45, n.5, p.351-360, 1991.

BRAGA, Kátia Soares. Aspectos relevantes para a seleção de metodologia adequada à pesquisa social em Ciência da Informação. In: MUELLER, Suzana Pinheiro Machado (Org.). Métodos para a pesquisa em Ciência da Informação. Brasília: Thesaurus, 2007.

BRIGGS, Asa; BURKE, Peter. Uma história social da mídia: de Gutenberg à Internet. 2 ed. Rio de Janeiro: Jorge Zahar Ed., 2006.

BROOKES, Bertram C. The foundations of information science: Part I. Philosophical aspects. Journal of Information Science. June, v. 2, p. 125-133, 1980. Disponível em:

<http://jis.sagepub.com/content/2/3-4/125>. Acesso em: 14 set. 2012. 
CALAZANS, Angélica Toffano Seidel. Estudo de caso - uma estratégia de pesquisa. In: MUELLER, Suzana Pinheiro Machado (Org.). Métodos para a pesquisa em Ciência da Informação. Brasília: Thesaurus, 2007.

CARVALHO, Isamir Machado de. Condições para criação de conhecimento numa organização de alta tecnologia. In: (Org.). Gestão do conhecimento: uma estratégia empresarial. Brasília: JJ Gráfica e Comunicações, 2006. P. 47-74. Cap. 2.

CASSARRO, Antônio Carlos. Sistemas de informações para tomada de decisões. 3. ed. São Paulo: Pioneira Thomson, 2003.

CÉSAR, Ana Maria Roux Valentini Coelho César. Comunicação e cultura organizacional. In: KUNSCH, Margarida Maria Krohling. (Org.). Gestão estratégica em comunicação organizacional. São Paulo: Difusão, 2008.

COMPUTERWORLD. Computerworld divulga CIOs finalistas do prêmio IT Leaders. São Paulo: Disponível em:

<http://computerworld.uol.com.br/carreira/2010/09/17/computerworld-divulga-os-ciosfinalistas-do-premio-it-leaders>. Acesso em: 20 mar. 2011

CORRÊA, Elizabeth Saad. Comunicação digital e seus usos institucionais. In: KUNSCH, Margarida Maria Krohling (Org.). Gestão estratégica em comunicação organizacional. São Caetano do Sul: Difusão, 2008. p. 169 - 184.

CHOO, Chun Wei. A organização do conhecimento: como as organizações usam a informação para criar significado, construir conhecimento e tomar decisões. 2. ed. São Paulo, SP: SENAC, 2006.

COMPUTERWORLD. Lista de finalistas IT Leaders 2010. Disponível em:

<http://computerworld.uol.com.br/finalistas-it-leaders-2010>. Acesso em: 20 mar. 2011

COURTRIGHT, Christina. Context in information behavior research. Annual Review of Information Science and Technology, v. 41. p. 273-306. 2007.

DAVENPORT, Thomas H. Ecologia da Informação: por que só a tecnologia não basta para o sucesso na era da informação. São Paulo: Futura, 2003.

DIAS, Cláudia Augusto (2001a). Métodos de avaliação de usabilidade no contexto de portais corporativos: um estudo de caso no Senado Federal. Dissertação (Mestrado em Ciência da Informação) - Universidade de Brasília. Brasília: UnB.

(2001b). Portal corporativo: conceitos e características. Ciência da Informação, Brasília, v. 30, n. 1, p. 50-60, jan./abr. Disponível em: <http://www.scielo.br/pdf/ci/v30n1/a07v30n1.pdf >. Acesso em: 14 mar. 2011.

DRUCKER, Peter. Administrando para o futuro: os anos 90 e a virada do século. 4. ed. São Paulo: Pioneira, 1992.

ELETROBRAS ELETRONORTE. Portal do conhecimento. Disponível em: <http://ucel.eln.gov.br/portaldoconhecimento/>. Acesso em: 02 fev. 2011. 
Informativo Novo Tempo. Brasília, ano 1, n. 007, out. 2010. Disponível em: < http://www.eln.gov.br/opencms/export/sites/eletronorte/modulos/novoNorte/arquivosNT/Nov oTempo007.pdf $>$. Acesso em: 02 fev. 2011.

Política de pesquisa, desenvolvimento e inovação. [S.1.: s.d.]. Disponível em: < http://www.eln.gov.br/opencms/opencms/publicacoes/>. Acesso em 17 out. 2012.

Relatório de sustentabilidade 2012. [S.l.]. Disponível em: < http://www.eln.gov.br/opencms/opencms/publicacoes/>. Acesso em: 11 set. 2013.

Cartilha modelo atual do setor elétrico. [S.l.: s.d.]. Disponível em: < http://www.eln.gov.br/opencms/opencms/publicacoes/>. Acesso em: 11 set. 2013.

ÉPOCA NEGÓCIOS ONLINE. As empresas mais inovadoras do Brasil 2011. Disponível em <http://epocanegocios.globo.com/Revista/Common/0,EMI271272-16364,00AS+EMPRESAS+MAIS+INOVADORAS+DO+BRASIL.html>. Acesso em: 21 mar. 2012.

FAUAT, Ana Matilde. Comunicação organizacional e padrões de comportamento informacional de gestores e analistas de risco de crédito em instituições financeiras governamentais. Brasília, 2007. Dissertação de mestrado apresentada ao Programa de PósGraduação em Ciência da Informação da Universidade de Brasília. Brasília, 2007.

FERNANDES, Amarildo da Cruz. Conhecimento e aprendizagem organizacional em perspectiva. Rio de Janeiro: ENEGEP, 1999. Disponível em:

http://www.abepro.org.br/biblioteca/ENEGEP1999_A0995.PDF>. Acesso em: 26 out. 2010.

FLEURY, Afonso \& FLEURY, Maria Tereza Leme. Aprendizagem e inovação organizacional : as experiências de Japão Coréia e Brasil. São Paulo: Atlas, 1995.

FIGUEIREDO, Saulo Porfírio. Portais corporativos: em direção ao B2E. Instituto Intranet Portal. 06 Jan. 2005. Disponível em: < intranetportal.org.br/wp/2005/01/portais-corporativosem-direcao-ao-b2e/>. Acesso em 21 mar. 2012.

GASQUE, Kelley Cristine Gonçalves Dias. Comportamento dos professores da educação básica na busca de informação para a formação continuada: estudo de caso dos Colégios Maristas. 2003. 180 f., il. Dissertação (Mestrado em Ciência da Informação) — Universidade de Brasília, Brasília, 2003. Disponível em: <http://hdl.handle.net/10482/9945>. Acesso em: 05 nov. 2012.

; TESCAROLO, Ricardo. Sociedade da aprendizagem: informação, reflexão e ética. Ciência da Informação, Brasília, v. 33, n. 3, dez. 2004. Disponível em: < http://www.scielo.br/pdf/ci/v33n3/a05v33n3.pdf>. Acesso em: 12 abr. 2013.

(2008a). O papel da experiência na aprendizagem : perspectivas na busca e no uso da informação. TransInformação, Campinas, v. 20 n. 2, p. 149-158, maio/ago. Disponível em: <http://hdl.handle.net/10482/9208> Acesso em: 15 dez. 2012.

(2008b). O pensamento reflexivo na busca e no uso da informação na comunicação científica. 2008. 242 f. Tese (Doutorado em Ciência da Informação)- 
Universidade de Brasília, Brasília. Disponível em: <http://hdl.handle.net/10482/1344>. Acesso em: 05 nov. 2012.

(2010); COSTA, Sely. Evolução teórico-metodológica dos estudos de comportamento informacional de usuários. Ciência da Informação, Brasília, v. 39, n. 1, jan./abr., 2010. Disponível em: < http://www.scielo.br/pdf/ci/v39n1/v39n1a02.pdf>. Acesso em: 15 dez. 2012.

(2012). Letramento informacional: pesquisa, reflexão e aprendizagem. Brasília: UnB, 2012. Disponível em: <http://leunb.bce.unb.br/handle/123456789/22 >. Acesso em: 19 jun. 2012.

GOLDENBERG, Mirian. A arte de pesquisar: como fazer pesquisa qualitativa em ciências sociais. 3. ed. Rio de Janeiro: Record, 2007.

GOMES, Antônio Claret S.; ABARCA, Carlos David G.; FARIA, Elíada Antonieta S. T.; FERNANDES, Heloísa Helena de O. BNDES 50 Anos - Histórias Setoriais: O Setor Elétrico. Dez. 2002. Disponível em:

http://www.bndespar.com.br/SiteBNDES/export/sites/default/bndes_pt/Galerias/Arquivos/con hecimento/livro_setorial/setorial14.pdf. Acesso em 02 nov. 2012.

Intranet Portal. Prêmio intranet portal. Base permanente de contato com a premiação, que reúne todas as informações sobre as edições anteriores e o processo corrente. Disponível em: http://intranetportal.org.br/wp/premio-intranet-portal/. Acesso em 07 Fev. 2013.

KOTLER, Phillip. Marketing para o século XXI: como criar, conquistar e dominar mercados. São Paulo: Futura, 1999.

KUNSCH, Margarida Maria Krohling. (Org.). Gestão estratégica em comunicação organizacional. São Paulo: Difusão Editora, 2008.

LE COADIC, Yves-François. A ciência da informação. 2. ed. Brasília: Briquet de Lemos, 2004.

LUPETTI, Marcélia. Gestão estratégica de comunicação. São Paulo: Thompsom Learning, 2007.

LUIZ, Dirceu S. Siqueira. Visão holística - que bicho é esse! Administradores.com - O portal da administração. 22 Jan. 2009. Disponível em: <

http://www.administradores.com.br/artigos/administracao-e-negocios/visao-holistica-quebicho-e-esse/27510/>. Acesso em 31 maio. 2013.

MAIA, Laryssa Rocha de Souza. A intranet como instrumento de endomarketing. 2010. 68 f. Monografia (Bacharelado em Administração)-Universidade de Brasília, Brasília, 2010. Disponível em: < http://bdm.bce.unb.br/bitstream/10483/1230/1/2010_LaryssaRochaMaia.pdf $>$ Acesso em: 02 maio. 2011

MALHOTRA, Naresh K.; et. al. Pesquisa de marketing: uma orientação. 4. ed. Porto Alegre: Bookman, 2008. 
MARTINEZ-SILVEIRA, Martha; ODDONE, Nanci. Necessidades e comportamento informacional: conceituação e modelos. Ciência da Informação, Brasília, v. 36, n. 2, Aug. 2007 . Disponível em: <http://www.scielo.br/scielo.php?script=sci_arttext\&pid=S0100$19652007000200012 \& \operatorname{lng}=$ en\&nrm=iso >. Acesso em: 03 ago. 2012.

MIRANDA, Antonio. Ciência da Informação: teoria e metodologia de uma área em expansão. Elmira Simeão (org.). Brasília: Thesaurus, 2003.

MORESI, Eduardo Amadeu. Delineando o valor do sistema de informação de uma organização. Ciência da Informação, Brasília, v. 29, n. 1, p. 14-24, jan./abr. 2000.

Disponível em:< http://www.scielo.br/pdf/ci/v29n1/v29n1a2.pdf> Acesso em: 22 maio. 2012

; MENDES, Sérgio Regina Peixoto. Compartilhamento do conhecimento em portais corporativos. TransInformação, Brasília, DF, 22.1, 1111 2010. Disponível em: $<$ http://periodicos.puc-campinas.edu.br/seer/index.php/transinfo/article/view/482>. Acesso em: 28 out. 2011.

NOKAKA, I.; TAKEUCHI, H. Criação de conhecimento na empresa. Rio de Janeiro: Campus, 1997.

NASSAR, Paulo. Conceitos e processos de comunicação organizacional. In: KUNSCH, Margarida Maria Krohling. (Org.). Gestão estratégica em comunicação organizacional. São Caetano do Sul: Difusão Editora, 2008. p. 61- 75.

PAVONI Jr, Gilberto. Geração X, Y e classe A. Revista Information Week Brasil, São Paulo, n. 231. p. 98 - 100. 22 set. 2010.

PETRY, André. A revolução pós-papel. Revista Veja, São Paulo, n. 51, p 150 - 158. 19 dez. 2012.

SALDANHA, Ricardo. (Org). Prêmio intranet portal 2011. Coleção Instituto Intranet Portal, 2012. Disponível em< http://www.clubedeautores.com.br/book/119842-Premio_Intranet_Portal_211> Acesso em: 21 mar. 2012.

; VIBERTI, Fernando. Intranets e portais corporativos no Brasil estão mais maduros. Instituto Intranet Portal. 17 Jan, 2011. Disponível em: < http://intranetportal.org.br/wp/2011/01/intranets-e-portais-corporativos-no-brasil-estao-maismaduros/>. Acesso em: 16 jun. 2013.

SANTAELLA, Lúcia.; NÖTH, Winfried. Imagem: cognição, semiótica, mídia. São Paulo: Iluminuras, 1999.

SANTOS, Raimundo Nonato Macedo dos; BERAQUET, Vera Silva Marão. Informação estratégica e empresa: o discurso à prova dos fatos. DataGramaZero - Revista de Ciência da Informação - v.2 n.3, jun,2001. Disponível em: <

http://www.dgz.org.br/jun01/Art_01.htm>. Acesso em: 25 nov. 2012.

SAWHNEY, M.; KOTLER, Phillip. In: Marketing in the age of information democracy. IACOBUCCI, Dawn (Org.). Kellogg on Marketing. New York: Ed. John Wiley \& Sons, Inc. 2001. 
SENGE, Peter. A quinta disciplina: arte, teoria e prática da organização de aprendizagem. 11 ed. São Paulo: Best Seller, 1990.

SEVERINO, Antônio Joaquim. Metodologia do trabalho científico. 23. ed. São Paulo: Cortez, 2007.

SGUARIO, Valéria Maria Gataz; TOMAÉL, Maria Inêz. Portal corporativo interno de um hospital universitário: um estímulo à aprendizagem organizacional 10.5007/1518-2924. 2011, v16, n32, p57. Encontros Bibli: revista eletrônica de biblioteconomia e ciência da informação, 16, out. 2011. Disponível em: <http://www.periodicos.ufsc.br/index.php/eb/article/view/1518-2924.2011v16n32p57>. Acesso em: 03 ago. 2012.

SHAFFER, Roberta. É preciso ser cético, duvidar. In: A revolução pós-papel. Revista Veja, São Paulo, n. 51, p. 156 - 157, 19 dez. 2012. Entrevista concedida a André Petry.

SOARES, Bruno Jorge. Comportamento de gestores de empresas de base tecnológica na busca e uso de informações. 2002. Dissertação (Mestrado em Ciências da Informação) Universidade de Brasília, Brasília, 2002.

SOUZA, Mauro Wilton de. Teoria da comunicação e gestão simbólica de processos organizacionais. In: KUNSCH, Margarida Maria Krohling. (Org.). Gestão estratégica em comunicação organizacional. São Caetano do Sul: Difusão Editora, 2008. p. 47 - 60. Taylor, Arthur. A study of the information search behaviour of the millennial generation. Information Research, vol. 17, no. 1, March 2012. Disponível em: <http://InformationR.net/ir/17-1/paper508.html>. Acesso em: 24 jun.2013.

TOMANIK, Eduardo Augusto. O olhar no espelho: "conversas" sobre a pesquisa em Ciências Sociais. 2. ed. Ver. Maringá: Eduem, 2004.

YANAZE, Mitsuru H. Gestão de marketing e comunicação: avanços e aplicações. São Paulo: Saraiva, 2006.

WERSIG, Gernot; NEVELING, Ulrich. Os fenômenos de interesse para a ciência da informação. Tradução do original: WERSIG, Gernot; NEVELING, Ulrich. The phenomena of interesting to information science. Information Scientist, v.9, n.4, p. 127-140, Dec. 1975. Disponível em:< http://www.alvarestech.com/lillian/GestaoDaInformacao/Rogerio/WersigNeveling.pdf>. Acesso em: 09 jun. 2010.

WILSON, T. D. (1981). On user studies and information needs. Journal of Documentation, v.31, n.1, p.3-15, 1981. Disponível em: 〈http://www.scielo.br/pdf/ci/v29n2/a09v29n2.pdf> Acesso em: 22 jun. 2013.

. (1999). Models in information behaviour research. Journal of Documentation, v. 55, n.3, p. 249-270. Disponível em:

<http://informationr.net/tdw/publ/papers/1999JDoc.html>. Acesso em: 22 jun. 2013.

(2000). Human information behavior. Informing Science, v. 3, n. 2, p. 49-55, 2000. Disponível em:<http://inform.nu/Articles/Vol3/v3n2p49-56.pdf >. Acesso em: 21 jun. 2013. 
(2007). Evolution in information behavior modeling: Wilson's model. In, K. Fisher, S. Erdelez \& L. McKechnie, (Eds.). Theories of information behavior, (pp. 31-36). Medford, NJ: Information Today. Disponível em:

<http://InformationR.net/tdw/publ/papers/2005SIGUSE.html> Acesso em: 21 jun. 2013. 


\section{APÊNDICES}

Apêndice A - Roteiro de entrevista do primeiro encontro.

Apêndice B - Segundo encontro com gestores -implantação da pesquisa.

Apêndice C - Questionário disponibilizado aos respondentes. 
Apêndice A - Roteiro de entrevista do primeiro encontro.

$1^{\circ}$ Encontro Eletronorte - 29/08/2012

Presentes: Andréa Carla Marques e

- Hugo Delgado Laranjeira - Webdesigner, responsável pelo Portal da Eletronorte

- Madalene Menezes Vertelo - Analista de treinamento - Gerência de Gestão do Conhecimento

- Sr. Francisco Fernandes Neto - Gerente de Gestão do Conhecimento

\section{Portal Eletronorte x Portal Eletrobras}

- Qual o grau de "submissão" do Portal de Conhecimento da Eletronorte em relação ao portal da holding Eletrobras?

Nenhuma. Os portais das subsidiárias são independentes. Não há links de acesso em nenhuma das vias Eletronorte

- Existe alguma política de padronização para os portais das subsidiadas?

Sim, padronização da comunicação visual.

- Há como ter acesso ao Portal da Eletrobras Eletronorte, à parte mais interna ( ou a "espelhos" - arquivos de imagem da intranet) para que possamos fazer uma investigação mais apurada?

Com senha de visitante - solicitar na portaria.

Portal Eletrobras Eletronorte - 1o. Lugar em Integração em TI no IIP

- Como é o tráfego diário/semanal de acessos ao Portal?

Na Eletronorte, a intranet é um dos principais canais de comunicação com o público interno. O portal corporativo está alinhado com as diretrizes do planejamento estratégico e é uma ferramenta importante de integração e mobilização dos colaboradores.

- Como tem sido a visitação: dentro do previsto, aquém ou além do esperado?

Em se tratando que ainda é pouco conhecido na organização, ele tem bastante acessos.

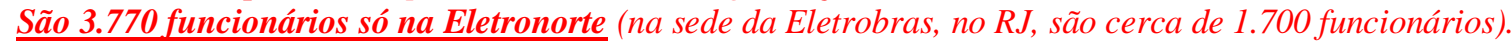
Em todo o sistema da Eletrobras, juntando todas as empresas, são mais de 26.000.000. Em cada STESociedade de Proposta Específica (uma parceira público-privada, formada a cada novo empreendimento um consórcio), a Eletronorte entra muitas vezes como operadora executiva (engenharia) do projeto, e o restante da administração fica distribuida por indicações dos demais parceiros. A "Norte Energia" é a STE responsável pela Usina de Belo Monte é um exemplo. Só ela abriga mais de 25 mil trabalhadores entre mão de obra direta e indireta - o que representa um grande impacto na economia local. Nem todos, no entanto, podem/necessitam acessar o portal.

OMOTIVO?

Ao que parece muita gente apaga e-mails sem ler, não têm hábito de buscar informação-mesmo em caso de cursos ou eventos gerenciais, por exemplo, há pouca frequência. Segundo o Sr. Francisco, Os colaboradores somente se sentem motivados a deixarem seus postos de trabalhos e afazeres para participarem de tais propostas quando há sorteio de brindes, um bom coffe-break ou algo do gênero. Outro possivel motivo (de acordo com Sr. Francisco): há uma grande diversidade de canais de comunicação, o que o faz "filtrar" as informações necessárias por canais. Isso muda quando há uma necessidade de informação específica

- O contador do site enumera pouco mais de 42 mil acessos -> em quanto tempo?

Os mais de 42 mil acessos tem sido registrados de outubro/2010 até hoje (29/08/2012).

- Quem é o gestor da área do Portal?

Na Eletronorte a gestão do conteúdo fica a cargo da GSEC.

A área de comunicação gerencia o conteúdo da intranet e internet => há diversas "ilhas de excelência", cada um com sua ideia de portal.

- Quanto aos acessos:

Quais os itens/programas mais acessados? (download e upload)

SW gerenciador de biblioteca - SophiA: há estatísticas de acesso conforme a área do portal - ver com

Hugo, o webmaster. que pode informar, por exemplo: qual é o assunto mais acessado/pesquisado; - qual

é o usuáriolárea da empresa que mais pesquisa; por período de tempo, etc. 
Continuação - Apêndice A - Roteiro de entrevista do primeiro encontro.

Não há como identificar por setor da empresa, devido a impossibilidade e identificação do IP (endereço do computador para acesso à Internet, por exemplo)

Quais os setores da organização que mais buscam informações?

Não há como identificar devido ao IP único da empresa.

E o que mais contribui (fornece) informações?

Também não há como identificar. Há políticas que versam sobre o fornecimento de material para o acervo: artigos, teses, dissertações..., quaisquer materiais feitos sobre a empresa deve ser fornecida uma cópia para o acervo. Ainda, colaborador cujo curso foi patrocinado pela empresa, obrigatoriamente deve enviar uma cópia do trabalho para a biblioteca/Portal, inclusive têm que autorizar a divulgação.

E, curiosamente, ao fazerem a divulgação de uma obra ou outra, ajudam a divulgar o Portal.

Existe algum ranking, alguma metodologia de mensurarão deste tráfego? Qual é o setor e gestor responsável pela área?

Nunca houve nenhum registro desse tipo. Há apenas divulgação a respeito de um ou outro material, o que aumenta a demanda para busca daquele produto.

PIDV - Plano de Incentivo de Demissão Voluntária - público que integra o "piloto" do PICC. Para que o funcionário possa aderir ao PIDV (e ganhar seu bônus), ele tem que participar do PICC. Em 2013

será realizado com diversos setores da empresa.

- Há alguma "caixa de sugestões", algum lugar onde o usuário possa depositar/informar suas demandas? Tem o "fale conosco", que entra em contato direto (por telefone ou email), com a área responsável pela demanda do material.

- Na parte mais interna do Portal Eletronorte, existe espaço para "redes sociais" e/ou formação de grupos de trabalho? Alguma ferramenta que fomente a interação entre usuários?

Existe: "share point", uma plataforma incentiva ao uso, porém não amadurecida.

Há um projeto de tornar a intranet mais colaborativa, porém está mais para "longo prazo" - um projeto das áreas de comunicação e informática.

\section{Outras observacões advindas da equipe gestora:}

- Os documentos ainda não estão todos digitalizados.

- Há muitas ilhas de excelência, precisa trabalhar o compartilhamento. Há diversos portais ainda não integrados - há uma "sopa de portais", que enfraquece cada um deles.

- Grande problema=> falta percepção da importância da GestCom ser "compartilhada", e não haver tantas "ilhas".

- Falta mais mkt da unidade de informação portal.

O PICC - Programa de Identificação e Compartilhamento de Conhecimento Crítico fez um levantamento das necessidades dos usuários da organização referente ao ano de 2010, com intuito de sistematizar o conhecimento tácito e torná-lo acessível.

- Houve alguma atualização desses dados? Eles estão acessíveis - os anteriores e os atuais? Eu poderei ter acesso a esses tópicos?

Esta prevista para 2013, quando o PICC será estendido aos demais setores da organização. Inclusive, pretende-se automatizar o processo, com a contribuição de um sistema próprio de "alimentação" desses dados. Acesso: É só solicitar por e-mail.

\section{Sobre o conteúdo/infraestrutura do Portal:}

- Como existem documentos ainda não digitalizados, quem se encarrega disso? Existe alguma previsão de conclusão para as atividades pendentes?

- E quanto à "sopa de portais"... Como dito em nosso $1^{\circ}$ contato, há diversos portais ainda não integrados. Há algum planejamento prevendo isso?

A política de padronização para os portais das subsidiadas do sistema Eletrobras está circunscrita apenas

à padronização visual e de marca ou tem de atender a padrões de conteúdo também, algo como "requisitos mínimos"? Se sim, poderiam informar que padrões?

Conclusão 
Apêndice B - Segundo encontro com gestores - implantação da pesquisa.

$2^{o}$ Encontro Eletronorte - 13/08/2013

Roteiro da entrevista

Encontro para definição do processo de pesquisa:

Alterações no organograma da GESEC $=>$ GAE. Alguma implicação/mudança relevante para a pesquisa?

Implicações da paralisação da empresa - negociações de acordo coletivo de trabalho, com dissídio coletivo instalado, Categoria do sistema Eletrobras em greve de 05 a 09/08/2013.

Pegar dados de acesso de agosto/2013, um ano depois da $1^{\text {a }}$. Reunião.

Avaliação do questionário e definição de alterações (se necessário).

Proposta - estratégia de realização da pesquisa e meios de colaboração:

Previsão do cronograma do projeto: duas semanas para a coleta de dados. Previsão era 01 a 16/08/2013. Pós-greve, qual melhor período?

Estratégia de apresentação/divulgação: realização em 2 etapas:

1 $^{\text {a }}$. Fase: envio de convite para participação por e-mail. Monitoramento diário da evolução da quantidade de respostas. Final da primeira semana sem quantidade representativa para amostra, cerca de 30 questionários respondidos, contabilizados de uma média de 370 acessos mensais $=>2^{\mathrm{a}}$. fase.

$\mathbf{2}^{\mathbf{a}}$. Fase: conquista de mais respondentes. Envio de novo convite incluindo a chance de concorrer ao sorteio de brindes.

Entregar proposta de texto para convite.

Apresentação de informações obtidas do pré-teste e do questionário. Disponibilizado link para acesso ao questionário.

Destacar que as questões tratam apenas da busca da informação no portal, sem referência específica a quaisquer documentos ou materiais estratégicos da organização, conforme informado desde o início do processo de pesquisa..

Compilação das respostas:

Alterações entre GESEC e GAE são internas, nada muda para o portal.

Greve - alteração de processos internos, acúmulo de trabalho. Mudanças no período de coleta de dados - ficou combinado novo prazo, semana de 14 a 21/08/2013.

Dados de acesso entregues pelo webmaster.

Estratégia de divulgação e alterações para o questionário, sugestões da equipe de profissionais da GAE, gestores do Portal do Conhecimento da Eletrobras Eletronorte:

- Evitar siglas no questionário - existem vários portais. Para evitar confusões melhor não utilizar siglas tipo PdCC. Referir-se apenas como Portal do Conhecimento. Reforço com prints de tela do portal, tela principal na abertura e cabeçalho no início dos demais tópicos.

- Outras alterações no questionário - na Eletronorte não há gestores. O termo aqui é gerente. Atenção à variação de gênero "usuário(a)". Usar definição de cargos conforme classificação da empresa - cargos de nível fundamental, nível médio operacional; nível médio suporte e nível superior.

- Destacar o filtro do instrumento: tem que ser usuário do portal. Tirar do texto de abertura e dar maior destaque, na forma de uma figura, bem chamativa.

- Divulgação da pesquisa - convite para participação da pesquisa via mensagem de correio eletrônico, assinada pela área gestora do portal. Para reforçar a seriedade da proposta, incluir nomes/logos da UCEL e UnB para indicar parceria na realização do projeto.

- Acesso à pesquisa - colocar link de acesso à pesquisa no corpo da mensagem-convite. Vai também para o Portal do Conhecimento. Webmaster fará banner específico.

- Período da pesquisa - Combinado período de 14 a 21/08/2013, inicia-se com a mensagem de e-mail da GAE. 
Apêndice C - Questionário disponibilizado aos respondentes.

\section{Comportamento de Pesquisa da Informação de Usuários(as) de Portais Corporativos}

Prezado(a) Senhor(a),

Estou realizando pesquisa de mestrado junto à Faculdade de Ciência da Informação $(\mathrm{FCl})$ da Universidade de Brasília, sob orientação da Profa. Dra. Kelley Cristine Gonçalves Dias Gasque, cujo objetivo é analisar o comportamento de pesquisa de informação dos usuários(as) do Portal do Conhecimento da Eletrobras Eletronorte com vistas à resolução de problemas.

O método adotado para o estudo está baseado na percepção dos(as) usuários(as) do portal sobre o problema investigado. Para tanto, sua participação é de extrema importância, não apenas por contribuir com o desenvolvimento de um projeto científico, mas também pelos resultados obtidos que serão analisados pelos gerentes do portal para possivel implantação de melhorias.

$O$ acesso a este questionário estará aberto até $21 / 08 / 2013$. São necessários poucos minutos para responder as questões e, ao final, basta clicar em "enviar o formulário" para concluí-la. Seu anonimato está garantido. Os dados sociodemográficos solicitados serão tratados agrupadamente sem identificação de participantes.

Coloco-me à disposição para eventuais esclarecimentos e agradeço imensamente sua colaboração e disposição em tomar parte deste projeto.

Muito obrigada!

Atenciosamente

Pesquisadora responsável: Andréa Carla Marques

E-mail: andreacarlaudi@amail.com

Telefone: (61) 8115.8292

*Obrigatório

Atençâo: se você não é usuário do Portal do Conhecimento da Eletronorte, por favor, não responda a este questionário.

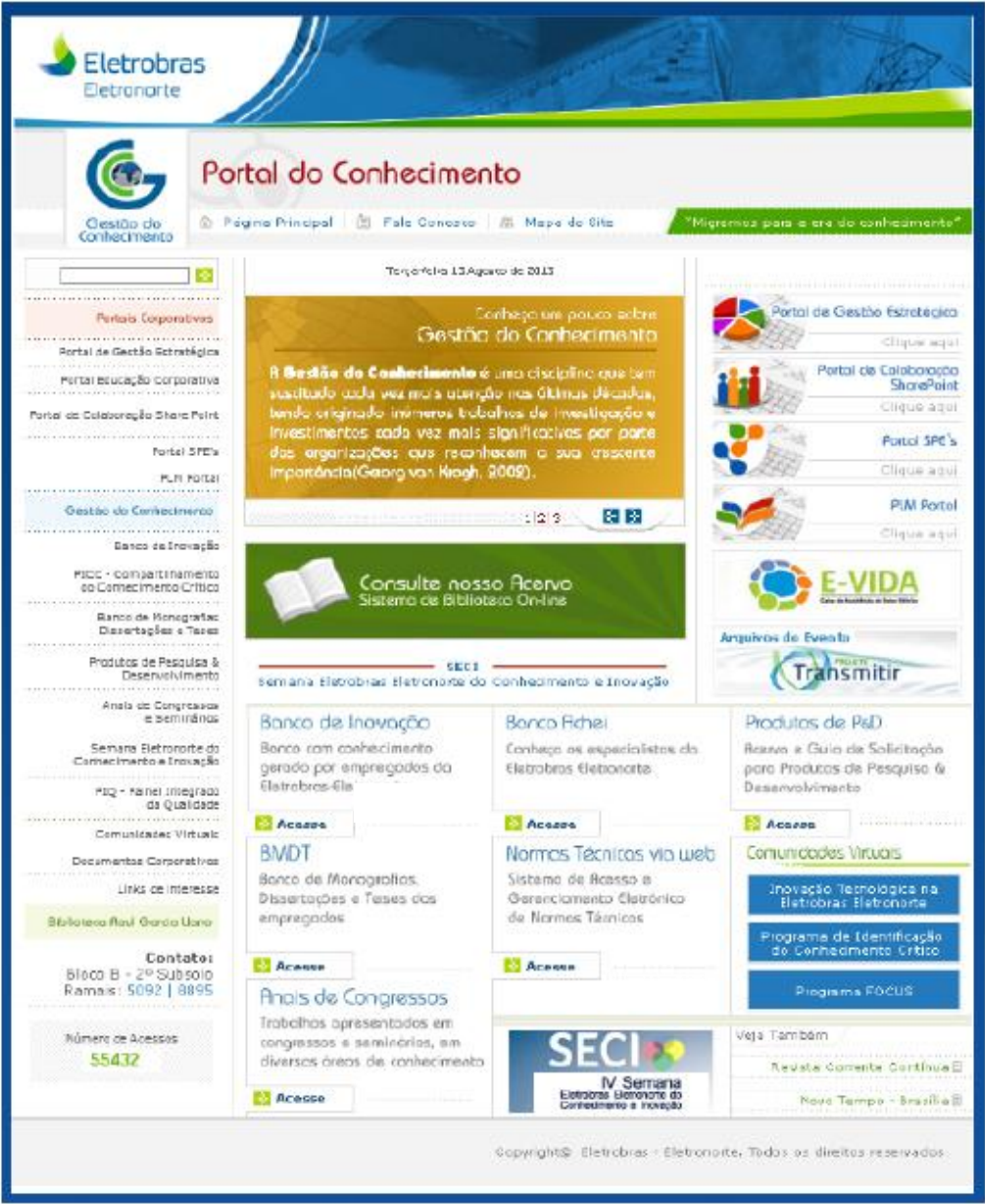

Continua 
Continuação - Apêndice C - Questionário disponibilizado aos respondentes.

\section{Quanto ao acesso do usuário(a).}

Esta seção visa identificar os fatores que estimulam a busca de informação e possiveis obstáculos. Importante: a expressão "informação qualificada" nas questões a seguir refere-se à informação que apoia o processo de tomada de decisão - sejam em situações rotineiras ou estratégicas.

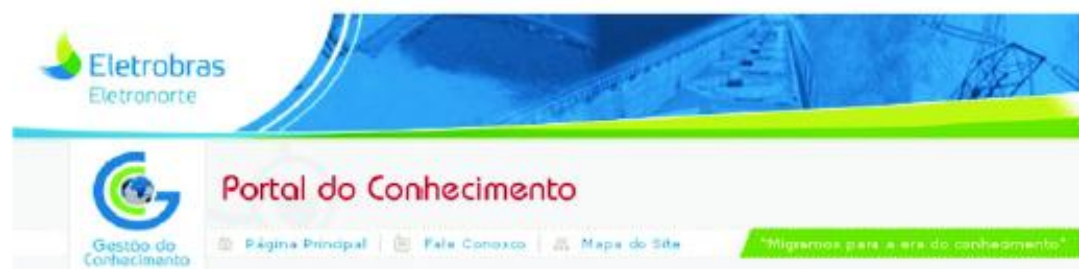

1. 1.1. Quanto ao acesso ao Portal do Conhecimento, o(a) Sr.(a) acessa o portal com que frequência? *

Marcar apenas uma oval.
Quase que diariamente
Vez em quando, cerca de 2 vezes por semana
Eventualmente, entre 2 a 5 vezes por mês
Esporadicamente, cerca de 6 vezes por mês
Muito raramente, cerca de 10 vezes por semestre
Nunca/Quase nunca

2. A respeito da facilidade e possiveis obstáculos para o acesso à informação qualificada no portal, o (a) $\mathbf{S r}(a) . .$.

Marcar apenas uma oval por linha.

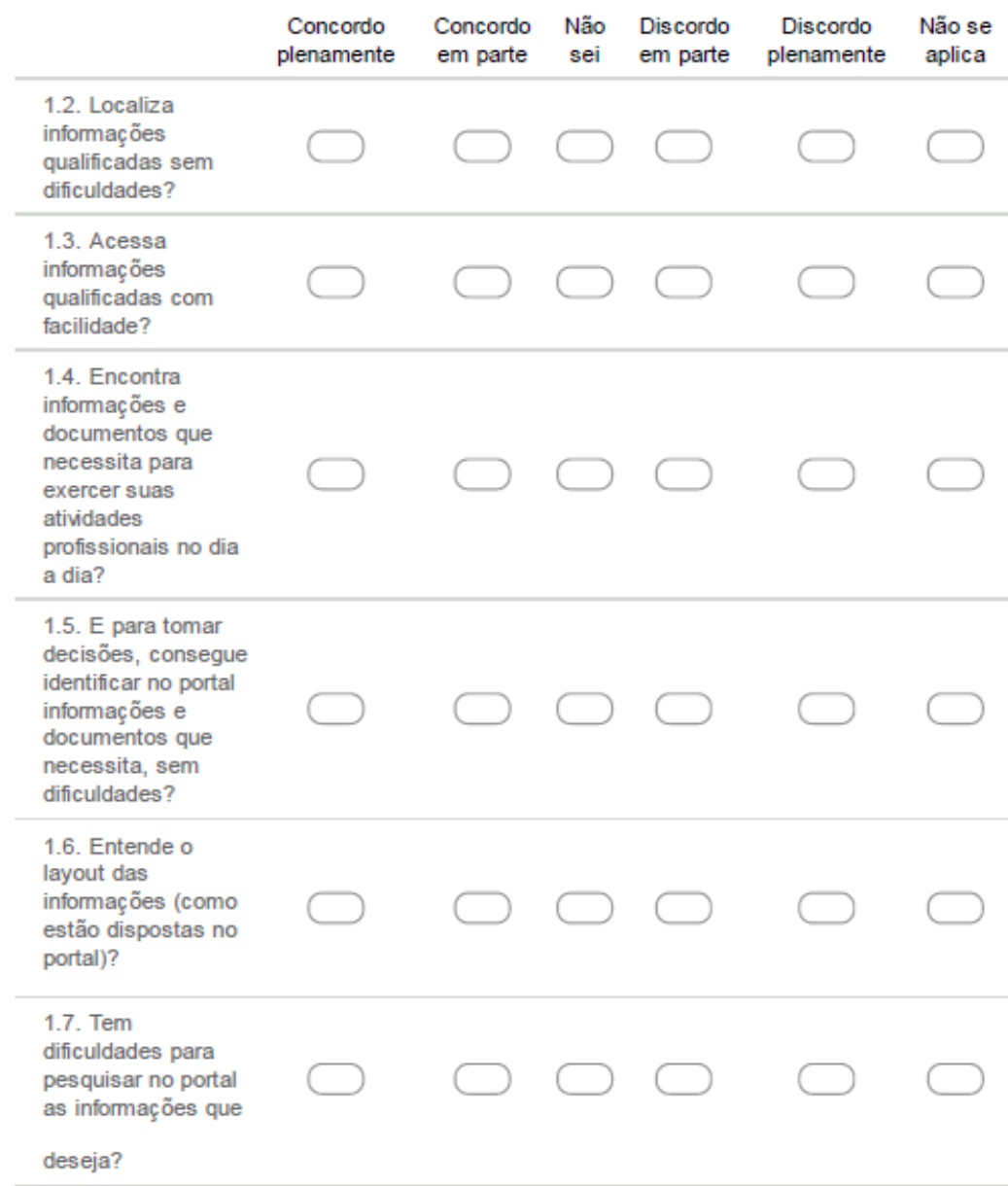

\section{Continua}


Continuação - Apêndice C - Questionário disponibilizado aos respondentes.

\begin{tabular}{|c|}
\hline $\begin{array}{l}\text { 1.8. O portal } \\
\text { disponibiliza } \\
\text { recursos que } \\
\text { facilitam a pesquisa } \\
\text { da informação? }\end{array}$ \\
\hline $\begin{array}{l}\text { 1.9. O portal } \\
\text { apresenta o } \\
\text { resultado da } \\
\text { pesquisa de } \\
\text { maneira } \\
\text { compreensivel? }\end{array}$ \\
\hline $\begin{array}{l}\text { 1.10. O portal } \\
\text { promove o uso e o } \\
\text { compartilhamento } \\
\text { dos conteúdos } \\
\text { disponibilizados? }\end{array}$ \\
\hline $\begin{array}{l}\text { 1.11. O portal } \\
\text { permite e/ou } \\
\text { estimula a } \\
\text { participação dos(as) } \\
\text { usuários(as) na } \\
\text { produção de novos } \\
\text { conteúdos? }\end{array}$ \\
\hline $\begin{array}{l}\text { 1.12. O portal } \\
\text { oferece meios que } \\
\text { facilitam a coleta de } \\
\text { ideias, informações } \\
\text { e sugestôes entre } \\
\text { os(as) usuários(as)? }\end{array}$ \\
\hline $\begin{array}{l}\text { 1.13. Há } \\
\text { comunicação sobre } \\
\text { as novas aquisições } \\
\text { ou novo conteúdo } \\
\text { disponibilizado? }\end{array}$ \\
\hline
\end{tabular}

2. Quanto à competência técnica para realizar pesquisa da informação.

Nesta parte, serão avaliados seus conhecimentos para acessar a informação disponibilizada no portal. $\mathrm{O}(\mathrm{A}) \mathrm{Sr}$.(a) diria que...

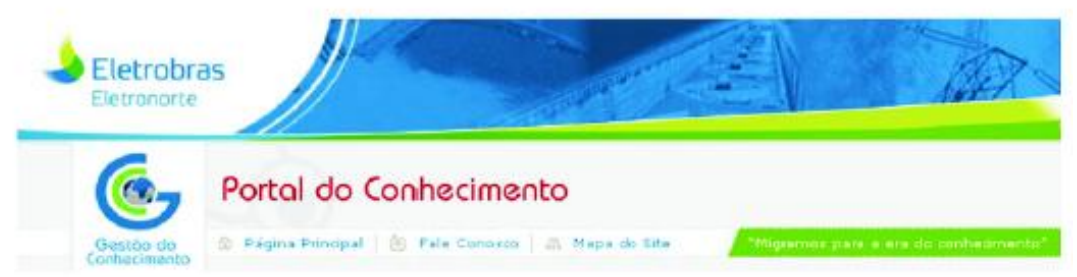

3. 2.1. Conhece técnicas que possam facilitar a pesquisa da informação, quando procura informação no portal? *

Marcar apenas uma oval.

Não

$\operatorname{Sim}$

4. 2.2. Utiliza algumas dessas técnicas que facilitam a pesquisa, quando procura informação no portal?

Marcar apenas uma oval.

Não

Sim (por favor, descreva quais, na próxima questão)

5. Por favor, descreva abaixo as

técnicas/ferramentas que mais utiliza ao

procurar informação no portal.

\section{Continua.}


Continuação - Apêndice C - Questionário disponibilizado aos respondentes.

6. 2.3. $\mathrm{O}(\mathrm{A}) \mathrm{Sr}$.(a) tem interesse em conhecer técnicas e ferramentas especificas que poderiam auxiliar em tarefas futuras de pesquisa de informação qualificada? *

Marcar apenas uma oval.

Não

Sim (por favor, descreva quais são as que lhe interessam na próxima questão)

7. Por favor, use este espaço para especificar quais técnicas/ferramentas tem interesse em aprender.

\section{Sobre a utilidade da informação para a tomada de decisão}

\section{e o compartilhamento da informação}

Aqui pretende-se caracterizar o atendimento (ou não) à demanda de informação qualificada.

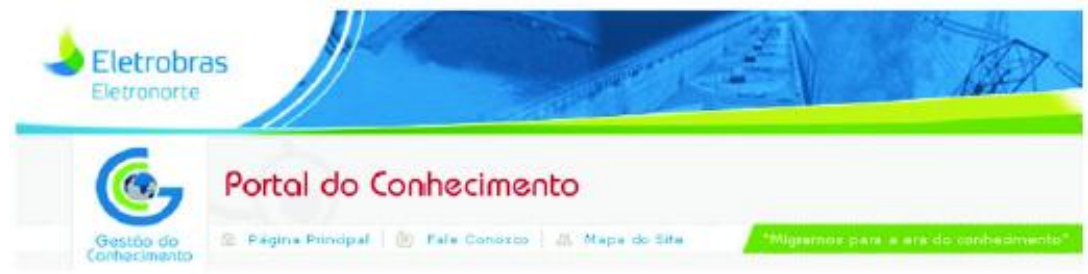

8. Sobre a demanda de informação qualificada, o(a) Sr.(a) busca informação no portal para..."

Marcar apenas uma oval por linha.

$\begin{gathered}\text { Concordo } \\ \text { plenamente }\end{gathered}$
3.1. Pesquisar a
respeito de ações
elou decisões já
tomadas (passado).
3.2. Pesquisar
informações para
complementar
alguma
ação/decisão atual
(presente).
3.3. Pesquisar
informação para dar
suporte a alguma
ação/decisão a ser
tomada (futuro).
3.4. Pesquisar
conteúdo técnico
(estatísticas, dados
de mercado,
publicações
técnicas, etc.).
3.5. Atualizar-se
sobre produtos e
serviços da
Eletrobras
Eletronorte (revistas
e jomais intemos,
comunicados e
demais informações
da organização).
3.6. Atualizar-se
sobre o mercadol
área de negócios.

Continua. 
Continuação - Apêndice C - Questionário disponibilizado aos respondentes.

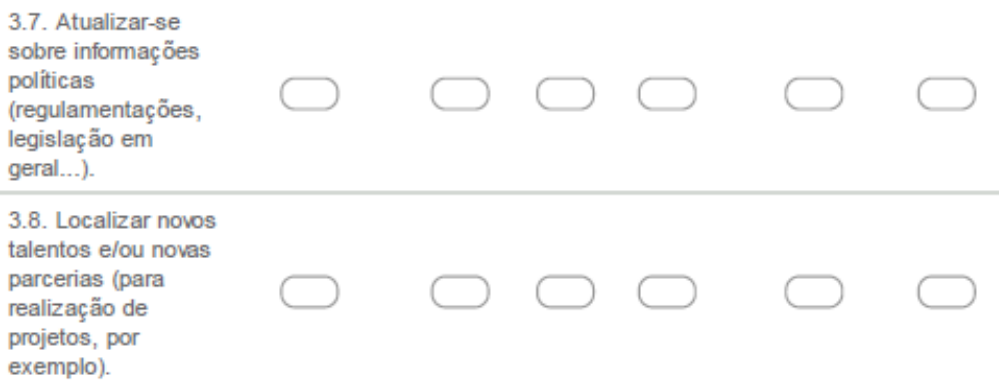

4. A seguir, desejamos saber sua opiniäo acerca do processo

de pesquisa e natureza da utilização das informaçōes obtidas a partir do Portal do Conhecimento da Eletrobras Eletronorte e que por ventura não tenham sido abordadas até agora.

Eletrobras Eletranorte

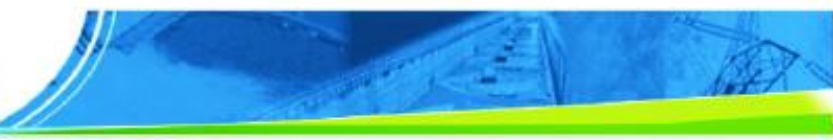

(6) Portal do Conhecimento

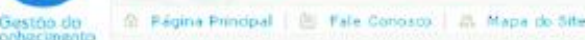

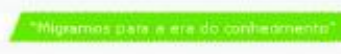

9. Use este espaço para incluir observaçöes e sugestões sobre o portal que julgar adequadas.

\section{Identificação do Perfil do Respondente}

Seu anonimato está garantido pois será necessário informar apenas alguns dados para montarmos um perfil geral de usuário(a).

Eletrobras

Eletronorte

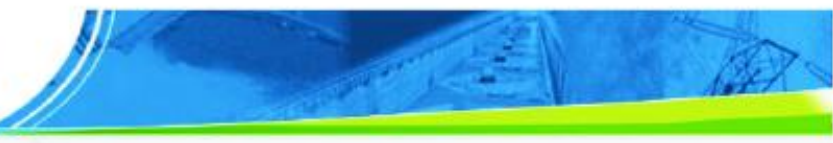

(7) Portal do Conhecimento

10. 5.1. Cargo que ocupa: *

Clique na seta abaixo para selecionar uma das opções.

Marcar apenas uma oval.
Profissional de Nivel Fundamental
Profissional de Nivel Médio Suporte
Profissional de Nivel Médio Operacional
Profissional de Nivel Superior

Continua 
Continuação - Apêndice C - Questionário disponibilizado aos respondentes.

11. 5.2. Nivel de escolaridade (selecione o grau mais recente de sua formação): * Clique na seta abaixo para selecionar uma das opções.

Marcar apenas uma oval.

Até o Ensino Médio ( $2^{\circ}$ grau)

Ensino Superior/Graduação em andamento

Ensino /Graduação Completa

Especialização em andamento

Especialização Completa

Mestrado em andamento

Mestrado Completo

Doutorado em andamento

Doutorado Completo

12. 5.3. Exerce função gerencial? *

Marcar apenas uma oval.

Não

Sim (por favor, assinale abaixo em que nivel)

13. Marcar apenas uma oval.

$\longrightarrow$ Nivel G1

Nivel G2

Nivel G3

14. 5.4. Tempo que trabalha na/para a Eletrobras Eletronorte: * Clique na seta abaixo para selecionar uma das opções. Marcar apenas uma oval.
Até 1 ano
De 2 a 5 anos
De 6 a 10 anos
De 11 a 15 anos
Mais de 15 anos
De 16 a 20 anos
Mais de 20 anos

15. 5.5. Faixa etária:

Marcar apenas uma oval.

$\bigcirc$ Até 25 anos

$\longrightarrow$ Entre 26 e 35 anos

Entre 36 e 45 anos

$\square$ Entre 46 e 55 anos

Acima de 55 anos

16. 5.6. Gênero: *

Marcar apenas uma oval.

Feminino

Masculino

\section{Google Drive}

Conclusão 


\begin{abstract}
ANEXOS
Anexo A - Informativo da pesquisa.

Anexo $\mathrm{B}$ - Reprodução de tela do portal, com banner para acesso à pesquisa.

Anexo C - Número de acessos ao portal-2012 e 2013.
\end{abstract}


Anexo A - Divulgação da pesquisa, enviada por correio eletrônico.

Mensagem enviada para profissionais da Sede-Brasília

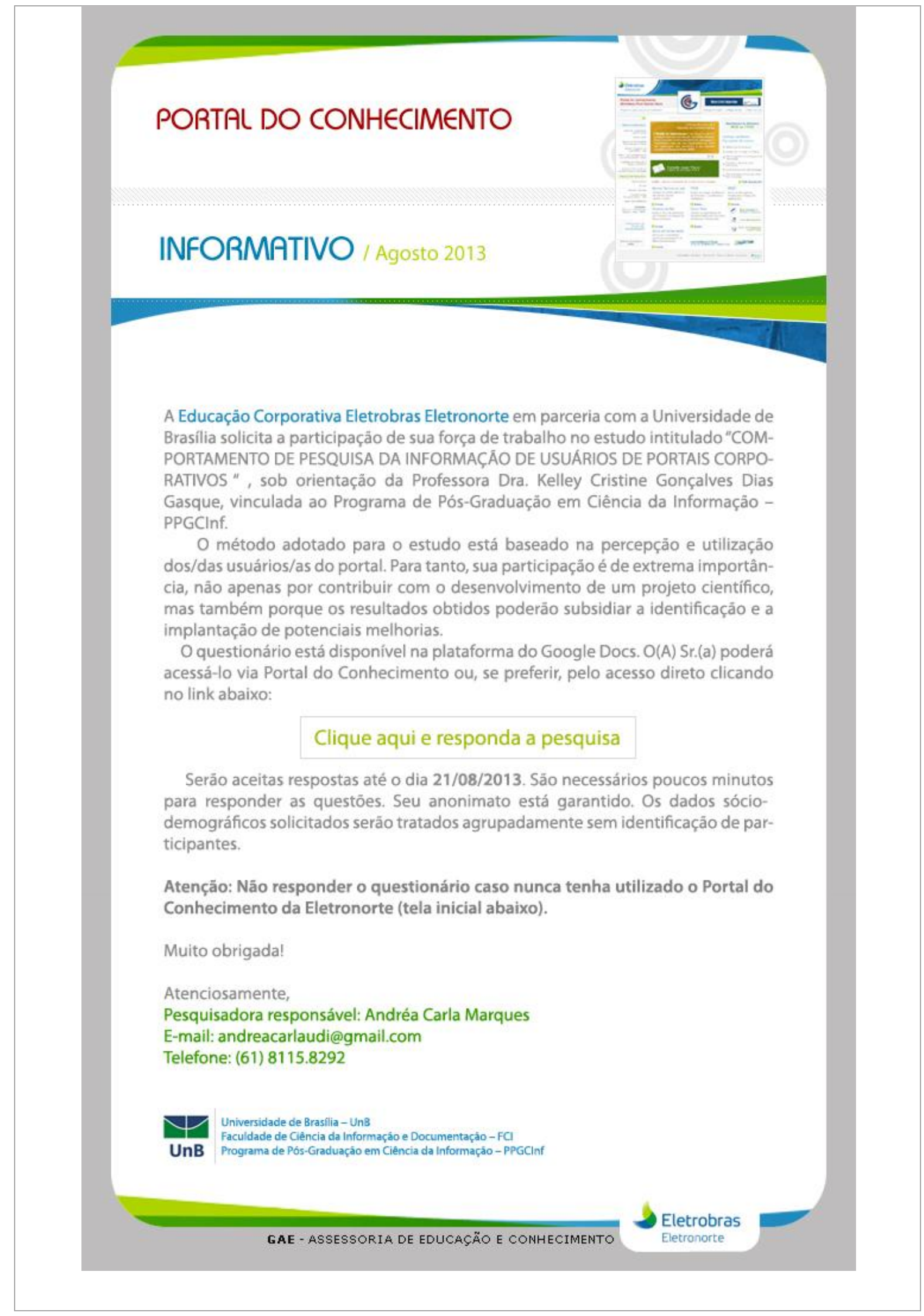


Anexo B - Reprodução de tela do portal, com banner para acesso à pesquisa.

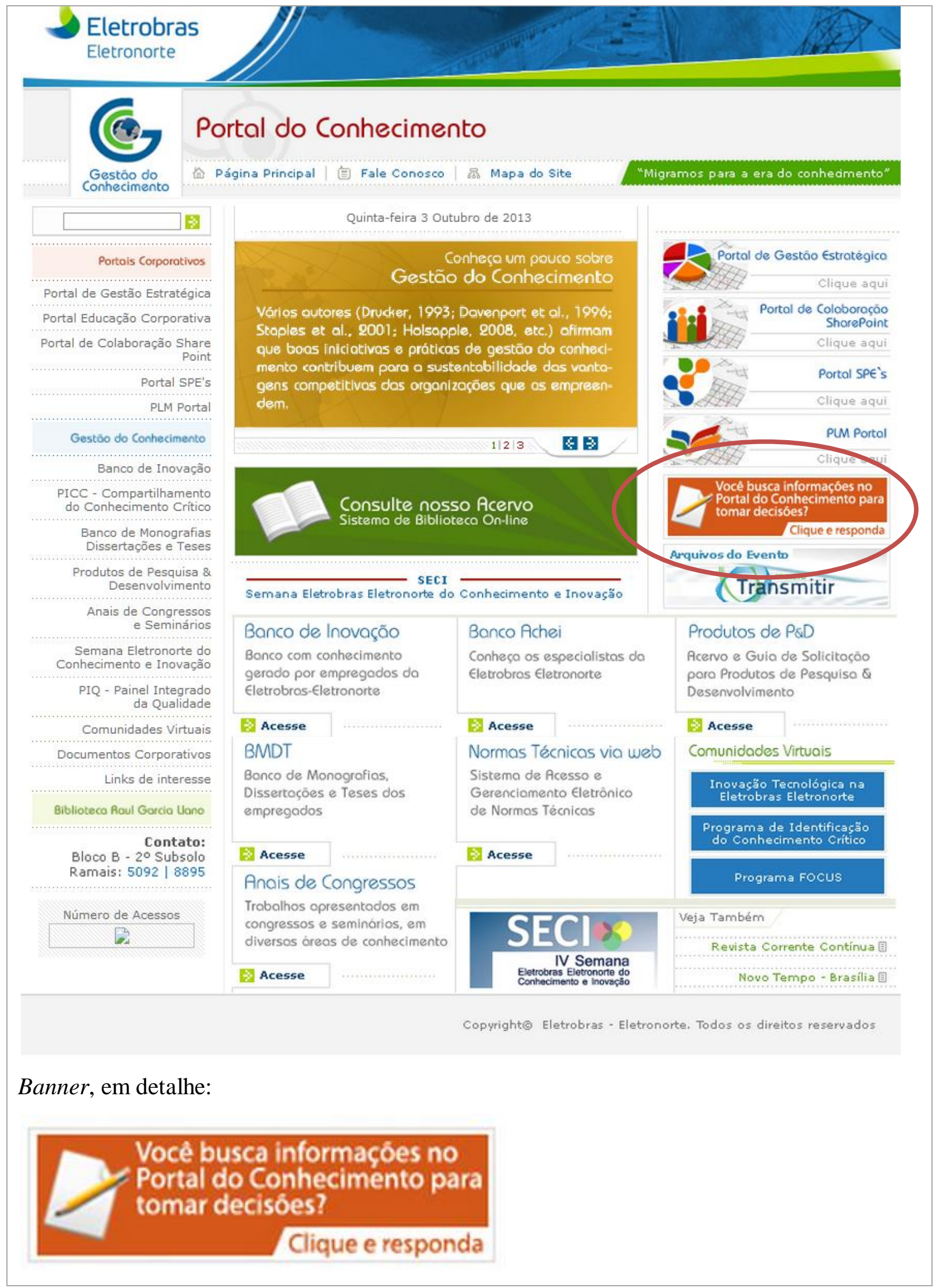


Anexo C - Número de acessos ao portal - 2012 e 2013.

\section{Estatística de acesso - Portal do Conhecimento}

Mês - Agosto/ 2012

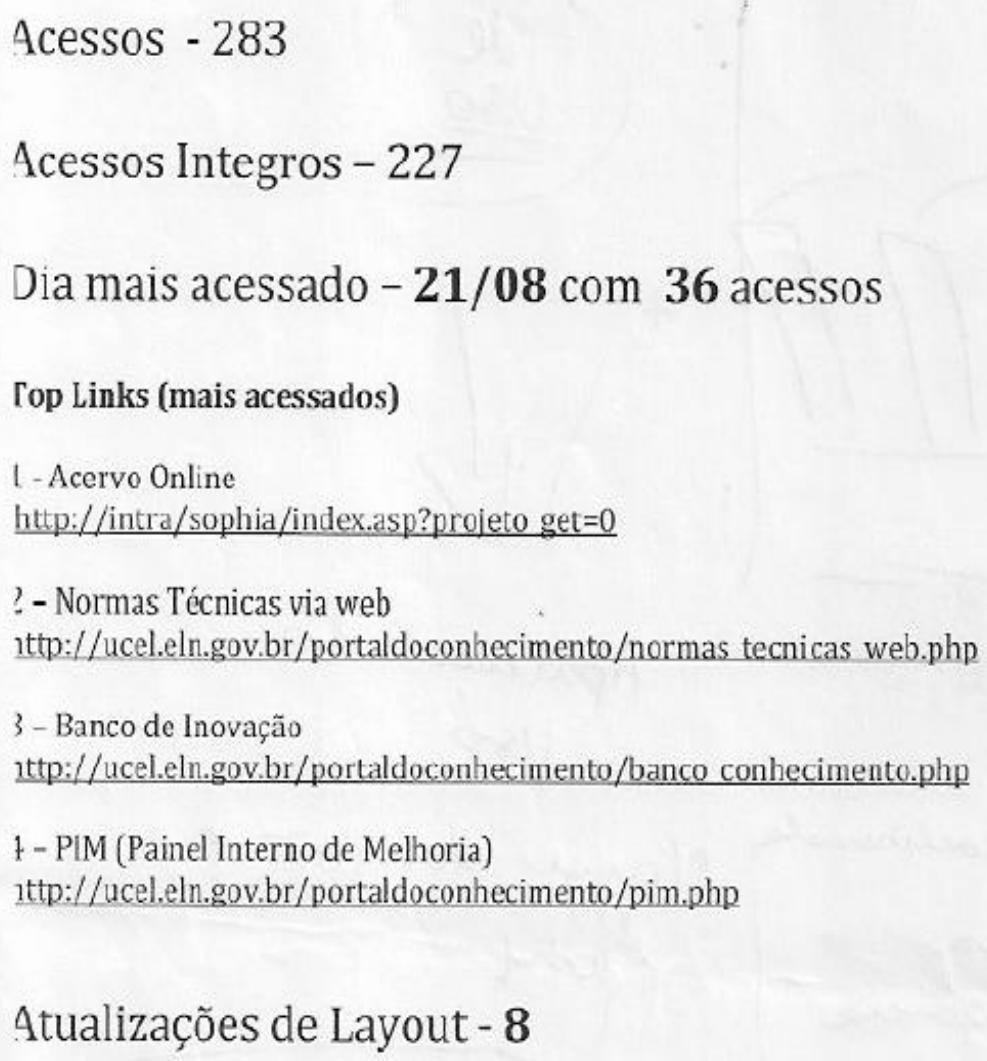

Estatística de acesso - Portal do Conhecimento Agosto/2013

Média de acesso ao Portal do Conhecimento nos últimos 8 meses:

\section{0}

Áreas mais acessadas nos últimos 6 meses:
1.Acervo Online
2.Normas Técnicas
3.PICC
4.SECI
5.BMDT 